UNIVERSIDADE DE SÃO PAULO

ESCOLA DE ARTES, CIÊNCIAS E HUMANIDADES

Programa de Pós-Graduação em Têxtil e Moda

PAULA DE MAIO IGLECIO COZZOLINO

\title{
O figurino no Cinema Marginal:
}

Rogério Sganzerla 
PAULA DE MAIO IGLECIO COZZOLINO

\section{O figurino no Cinema Marginal: Rogério Sganzerla}

Dissertação apresentada à Escola de Artes, Ciências e Humanidades da Universidade de São Paulo para obtenção do título de Mestre em Ciências do Programa de PósGraduação em Têxtil e Moda.

Versão corrigida contendo as alterações solicitadas pela comissão julgadora em 18/02/2016. A versão original encontra-se em acervo reservado na Biblioteca da EACH/USP e na Biblioteca Digital de Teses e Dissertações da USP (BDTD), de acordo com a Resolução CoPGr 6018, de 13 de outubro de 2011.

Área de Concentração:

Têxtil e Moda

Orientadora:

Profa $^{a}$.Dra. Isabel Cristina Italiano 
Autorizo a reprodução e divulgação total ou parcial deste trabalho, por qualquer meio convencional ou eletrônico, para fins de estudo e pesquisa, desde que citada a fonte.

CATALOGAÇÃO-NA-PUBLICAÇÃO

(Universidade de São Paulo. Escola de Artes, Ciências e Humanidades. Biblioteca)

Cozzolino, Paula de Maio Iglecio

O figurino no cinema marginal : Rogério Sganzerla / Paula de Maio Iglecio Cozzolino ; orientadora, Isabel Cristina Italiano. - São

Paulo, 2016

$165 \mathrm{f.}:$ il

Dissertação (Mestrado em Ciências) - Programa de Pós-

Graduação em Têxtil e Moda, Escola de Artes, Ciências e

Humanidades, Universidade de São Paulo

Versão corrigida

1. Moda. 2. Figurino. 3. Cinema - Brasil. 4. Cineastas -

Brasil. 5. Sganzerla, Rogério, 1946-2004. I. Italiano, Isabel

Cristina, orient. II. Título.

CDD 22.ed. -391 
Nome: Cozzolino, Paula de Maio Iglecio

Título: O figurino no Cinema Marginal: Rogério Sganzerla.

Dissertação apresentada à Escola de Artes, Ciências e Humanidades da Universidade de São Paulo para obtenção do título de Mestre em Ciências do Programa de PósGraduação em Têxtil e Moda.

Área de Concentração:

Têxtil e Moda

Aprovado em:

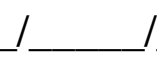

Banca Examinadora

Prof. Dr.

Instituição:

Julgamento:

Assinatura:

Prof. Dr.

Instituição:

Julgamento:

Assinatura:

Prof. Dr.

Instituição:

Julgamento:

Assinatura: 
Ao meu esposo, minhas filhas, meus pais e toda minha família, com amor, admiração e reconhecimento pela compreensão, carinho, presença, paciência e incansável apoio ao longo do período de elaboração deste trabalho. 


\section{Agradecimentos}

À Dra. Isabel Cristina Italiano, por ter acreditado neste projeto, pelo apoio durante o processo de definição e orientação.

Ao Dr. Rubens Luis Ribeiro Machado Júnior, pelo conhecimento e atenção ao eleger o cineasta estudado.

À jornalista Cristina Iglecio, pela revisão e mestria das palavras.

À Escola de Comunicações e Artes e Faculdade de Arquitetura e Urbanismo, pelo apoio nas aulas específicas.

À Escola de Artes, Ciências e Humanidades pela oportunidade de realização do curso de mestrado. 
"Por definição o cinema é ritmo e movimento, gesto e continuidade. Em tudo o que vemos, temos que considerar três aspectos: a posição do olho que olha, a do objeto visto e a da luz que ilumina a realidade. Assim, o cinema não tem função de preencher um buraco na parede já que sua missão é bem maior - ser uma janela sobre o mundo". 


\section{RESUMO}

COZZOLINO, Paula de Maio Iglecio. O figurino no Cinema Marginal: Rogério Sganzerla. 2016. 163 f. Dissertação de Mestrado em Ciências - Escola de Artes, Ciências e Humanidades, Universidade de São Paulo, São Paulo, 2016.

Esta pesquisa analisa e documenta os figurinos criados para o cinema brasileiro na obra "O Bandido da Luz Vermelha" de Rogério Sganzerla, a qual tem como pano de fundo o Cinema Marginal. Focaliza o trabalho de figurino neste período, com o objetivo de contribuir para a memória coletiva nacional e enriquecer o material de investigação dos profissionais ligados à área. O estudo se faz a partir de um levantamento dos aspectos sócio-político-culturais do país nas décadas de 60 e 70, refletidos num cinema que aparece como uma reação à situação por que passava o país no período de 1964 - 1968, com a politização das manifestações artísticas face aos fechamentos ocasionados pela ditadura militar. A partir da análise do filme e entrevistas com profissionais participantes ou ligados à obra do autor, como o operador de câmera Carlos Ebert, o qual também atuou como fotógrafo no filme "O Bandido da Luz Vermelha"; a diretora e atriz Helena Ignez, ícone do Cinema Marginal e esposa de Rogério Sganzerla; e o diretor e produtor Julio Calasso Junior, inicia-se um entendimento do processo criativo utilizado nos filmes produzidos pelo cineasta, num relevante período da história do cinema nacional. Indaga como os trajes colaboram para a construção dos personagens numa obra cinematográfica e a importância do figurino na criação destes personagens, tanto para o diretor como para o próprio ator, e como a escolha dos elementos e materiais corretos compõe plasticamente esta figura e contribuiu na sua gestualidade. Verifica o mérito de uma direção de arte com referências ao Pop, em sua acepção mais verdadeira, a de popular; com uma linguagem de quadrinhos, onde apresenta alguns personagens que são verdadeiras caricaturas do povo brasileiro e, assim, avalia como os elementos visuais se tornam o suporte do discurso.

Palavras-chave: Moda. Figurino. Figurinista. Cinema Marginal. Rogério Sganzerla. 


\begin{abstract}
COZZOLINO, Paula de Maio Iglecio. Cinema Marginal Costumes: Rogério Sganzerla. 2016. 163 p. Dissertation Master Sciences. - School of Arts, Sciences and Humanities, University of São Paulo, São Paulo, 2016.
\end{abstract}

This research verifies and documents costumes created for the Brazilian cinema into the work "O Bandido da Luz Vermelha" by Rogério Sganzerla, which has as its backdrop the Marginal Cinema. It focuses on the work developed for costumes in this period, aiming at contributing to the national memory and at the improvement of the research material of professionals connected to the area. The study was developed considering a deep investigation of social, political and cultural aspects of the country in the 60 's and 70 's, reflected in a movie that shows up as a reaction to the cultural situation the country was going through in the period between 1964 and 1968, with the politicization of artistic manifestations against the closures imposed by the military dictatorship. Based on the analysis of the film and interviews with some professionals close to the author, as the director of photography Carlos Ebert, who also worked as a photographer in the movie "O Bandido da Luz Vermelha"; the director and actress Helena Ignez, Cinema Marginal icon and Rogérios Sganzerla wife; and the director and producer Júlio Calasso Junior, it develops a new understanding of the creative process used in films produced by the film-maker Rogério Sganzerla, in this relevant period of the national cinema history. It questions how the costumes may contribute to the characters' building in a cinematographic work, its significance for both the director and the actor, and how the chosen elements and right materials shape the image aesthetically and contributes to the artist's gestures. It verifies the merit of an art direction, with references to Pop, in its most relevant meaning, which is to be 'popular', with comic book language style, in which some characters who are true caricatures of the Brazilian people are featured, and assesses how well the visual elements become the support for the speech.

Keywords: Fashion. Costume. Costume Designer. Marginal Cinema. Rogério Sganzerla. 


\section{LISTA DE FIGURAS}

Figura 1 - Cena do filme: "Deus e o Diabo na terra do sol" (1964)........................16

Figura 2 - Cena do filme "Sem essa Aranha", dirigido por Rogério Sganzerla, 1970.

Figura 3 - Cena do filme "A Margem", 1967, de Ozualdo Candeias.

Figura 4 - Os cineastas Carlos Reichenbach e Rogério Sganzerla no início dos anos 70 na Boca do Lixo, em foto de Ozualdo Candeias. .25

Figura 5 - O Bar Soberano, ponto de encontro de diretores, atores, produtores e outros ligados à indústria cinematográfica, localizado na Boca do Lixo..................26

Figura 6 - A foto mostra o transporte de filmes na região da Boca do Lixo...... .26

Figura 7 - Atriz não identificada se exibe para diretores e produtores em foto do início dos anos 70 na Boca do Lixo. Foto de Ozualdo Candeias.

Figura 8 - A atriz Helena Ignez em cena do filme "Sem essa Aranha" (1970)

Figura 9 - Helena Ignez no filme: "A família do barulho", de Júlio Bressane, 1970...32

Figura 10 - O ator Paulo Villaça em cena de "deglutição aversiva" no filme "O

Bandido da Luz Vermelha", 1968.

Figura 11 - Paulo Villaça após beber tinta em cena do filme "O Bandido da Luz

Vermelha", 1968.

Figura 12 - Rogério Sganzerla, primeiro à esquerda, Júlio Bressane, quarto a partir

de Rogério, com a equipe da Belair.

Figura 13 - Gladys em cena do filme "Sem essa Aranha", de Rogério Sganzerla, 1970.

Figura 14 - O Bandido experimenta vários óculos em sequência do "Bandido da Luz

Vermelha", 1968, onde se observa diversos objetos de cena sobre a mesa. .38

Figura 15 - Jorge Loredo no filme "Sem essa Aranha", de Rogério Sganzerla, 1970.

Figura 16 - Paulo Villaça interpretando "O Bandido da Luz Vermelha”, 1968. 42

Figura 17 - Cena do filme "A Mulher de Todos" (1969).

Figura 18 - Sonia Silk (Helena Ignez) em cena do filme "Copacabana, Mon Amour" (1970), de Rogério Sganzerla.

Figura 19 - Maria Gladys em cena do filme "Sem essa Aranha" descendo a Ladeira do Vidigal, Rio de Janeiro, aos berros. .43

Figura 20 - Jô Soares como Doctor Plirtz em "A Mulher de Todos". 
Figura 21 - Norma Bengell interpretando a personagem Madame Zero em "Abismu" (1977).

Figura 22 - Capa do jornal "O Pasquim”, número 33, em 1970.

Figura 23 - Louis Aragon, Daniel Cohn-Bendit, Alain Geismar em maio de 1968 na

Place de La Sorbonne.

Figura 24 - Os "Mutantes", Caetano Veloso e Gilberto Gil na estreia de "Divino

Maravilhoso", na TV Tupi, em 28 de outubro de 1968.

Figura 25 - Brigitte Bardot no set de filmagem do filme "A verdade", de Henri-

Georges Clouzot, 1960. 55

Figura 26 - Helena Ignez na cena do filme "A Mulher de Todos", 1969. .55

Figura 27 - Jimi Hendrix no Festival de Woodstock, em 1969. .56

Figura 28 - Cena do filme "O Pornógrafo", de João Callegaro, 1970. .59

Figura 29 - Cena do filme "O Estranho", de Orson Welles, 1946. .59

Figura 30 - A atriz Danusa Leão em cena do filme "Terra em Transe" (1967) vestindo figurino criado por Guilherme Guimarães. 65

Figura 31 - O Bandido (Paulo Villaça) vestindo o chapelão. 69

Figura 32 - Cena em que o Bandido rouba a farda militar no armário de uma de suas vítimas. 69

Figura 33 - O Bandido cobre o rosto com o jornal "O Dia". .83

Figura 34 - Retrato do verdadeiro Bandido da Luz Vermelha, João Acácio Pereira da Costa, após ser capturado em 1967. .85

Figura 35 - Luminoso em cena do filme. .87

Figura 36 - Criança na favela, habitante do "Lixão". .88

Figura 37 - Primeiro figurino do protagonista no filme "O Bandido da Luz Vermelha" .88

Figura 38 - O Bandido usando um colar feminino de uma de suas vítimas. .90

Figura 39 - O protagonista dá tiros pela cidade dentro de um automóvel. .91

Figura 40 - Delegado Cabeção veste os óculos dentro da viatura de polícia. .92

Figura 41 - Delegado Cabeção usando óculos em cena noturna...........................92

Figura 42 - Delegado Cabeção tira os óculos em cena noturna.............................93

Figura 43 - "Anão Profeta" repetindo o refrão nonsense diante do muro. .94

Figura 44 - "Anão Profeta" repetindo a segunda parte do refrão nonsense diante de uma grade. .94

Figura 45 - Janete Jane aparece pela primeira vez ao lado de seu cafetão. 95 
Figura 46 - O Bandido gargalha ao roubar um carro. .96

Figura 47 - O Bandido vestindo um chapéu feminino diante do armário de uma de suas vítimas.

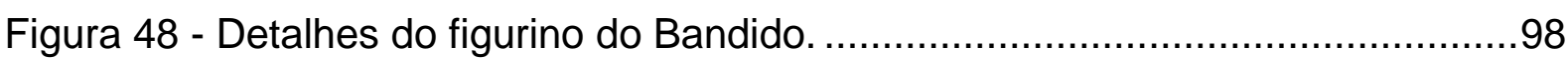

Figura 49 - Delegado Cabeção revela o uso de coldre de ombro. ...........................99

Figura 50 - O protagonista experimenta roupas na loja. ....................................100

Figura 51 - O protagonista experimenta casaco xadrez....................................100

Figura 52 - O cineasta Ozualdo Candeias faz ponta no filme. ………………......101

Figura 53 - O Bandido escreve cartas anônimas. ................................................102

Figura 54 - O Bandido escreve cartas anônimas com luva....................................102

Figura 55 - O Bandido prepara uma bebida......................................................

Figura 56 - O Bandido beija uma de suas vítimas.................................................104

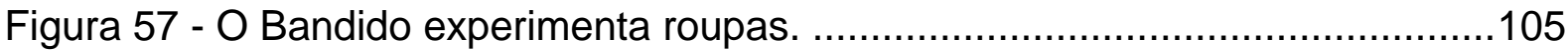

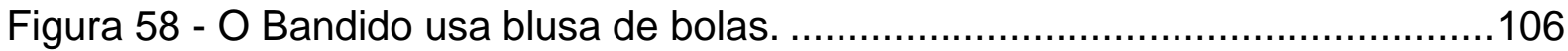

Figura 59 - O protagonista como clown tragicômico. ..........................................106

Figura 60 - O Bandido carrega uma de suas malas..............................................107

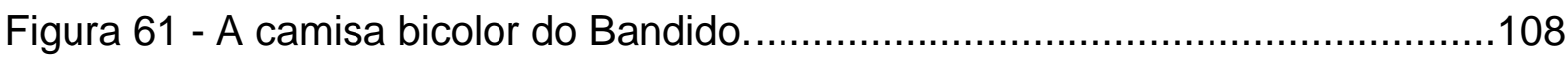

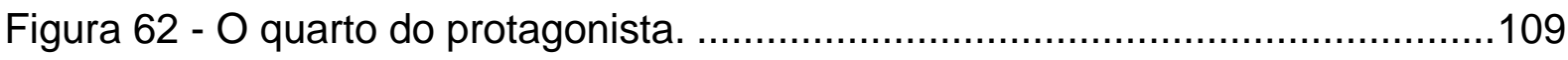

Figura 63 - O personagem central diante de seu armário...................................109

Figura 64 - O Bandido assiste a um filme com binóculos.....................................111

Figura 65 - O Bandido diante das fachadas dos cinemas.................................112

Figura 66 - O Bandido usa camisa com estampa psicodélica...............................113

Figura 67 - Primeiro figurino da "Madame Misteriosa". .........................................114

Figura 68 - Segundo figurino da "Madame Misteriosa". .....................................114

Figura 69 - Detalhe da calça e cinto do Bandido................................................115

Figura 70 - O Bandido e o planador que comprou. ................................................116

Figura 71 - Cena intercalada onde o Bandido picha o muro. …….......................117

Figura 72 - Uma das amantes do Bandido com maquiagem da época...................117

Figura 73 - Outra amante do Bandido com look clássico da década de 60............118

Figura 74 - O "Gay exagerado" com o zíper aberto...............................................119

Figura 75 - O "Gay exagerado" dá receita de pudim ao Bandido...........................119

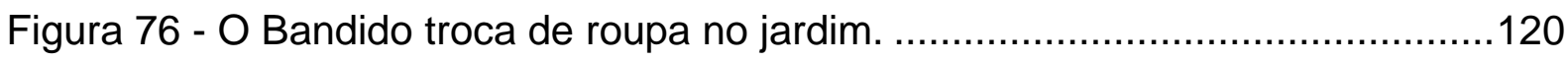

Figura 77 - O Bandido bebe tinta diante de muro branco com pichações................121

Figura 78 - O Bandido bebe tinta diante de muro com folhas. .............................122 
Figura 79 - J.B. Da Silva desce do avião. 123

Figura 80 - Janete Jane aguarda o Bandido chegar. ..........................................124

Figura 81 - Janete Jane encosta no carro do Bandido..........................................125

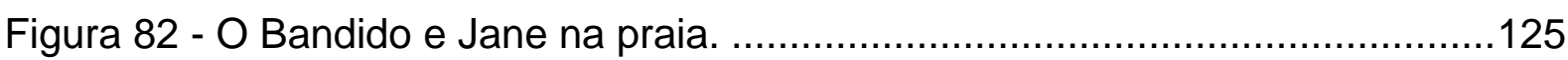

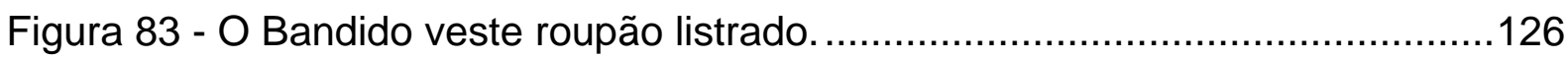

Figura 84 - O Bandido diz a famosa frase: "Sozinho é ridículo, a gente não pode fazer nada. Quando não pode fazer nada, a gente avacalha, avacalha e se esculhamba".

Figura 85 - Janete Jane tenta abrir o porta malas e o Bandido a impede..............128

Figura 86 - O protagonista espirra inseticida pelos ares. .....................................129

Figura 87 - O Bandido se joga no mar, numa tentativa de suicídio.......................130

Figura 88 - J.B. Da Silva dá entrevista em emissora de televisão.........................130

Figura 89 - A amante dá a notícia da falsa gravidez ao Bandido. .........................131

Figura 90 - A amante entrega o dinheiro do Bandido para o cafetão Lucho Gatica.

Figura 91 - Janete Jane vasculha o porta-malas do carro do Bandido em busca da verdadeira identidade dele.

Figura 92 - Janete Jane descobre a identidade do Bandido.

Figura 93 - Janete Jane e Lucho Gatica jogam bilhar.

Figura 94 - Janete Jane na fortaleza de J. B. Da Silva.

Figura 95 - Cangaceiro em frente à "fortaleza" do Luz.

Figura 96 - J.B. Da Silva fala sobre a pobreza.

Figura 97 - J.B. Da Silva discursa nas ruas de São Paulo.

Figura 98 - O Bandido prepara sua última bomba.

Figura 99 - O Bandido assassina Janete Jane.

Figura 100- O corpo de Janete Jane estendido no chão, ensanguentado após o tiro.

Figura 101 - A prostituta amiga de Jane tira os fogos da cinta-liga.

Figura 102 - A prostituta caminha ao lado do corpo de Janete Jane.

Figura 103 - O Bandido corre com fogos de artifício após a morte da amante. ......143

Figura 104 - O Bandido vê seu retrato falado no jornal.........................................143

Figura 105 - O Bandido arremessa seus pertences da mala na água. ...................144

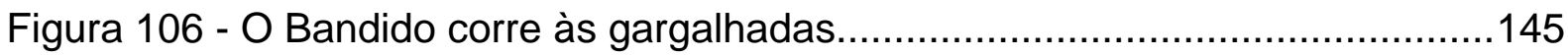

Figura 107 - O Bandido finge ter sido atingido nos ombros. ...............................146 
Figura 108 - O Bandido pisa na chave de força para se suicidar.

Figura 109 - O Bandido abre os braços antes de cair ao chão. 147

Figura 110 - Delegado Cabeção observa o cadáver, mas não crê ser o Bandido da Luz Vermelha. 148

Figura 111 - O Bandido e o Delegado Cabeção mortos, com a mesma posição ...149 Figura 112 - $\mathrm{O}$ ator Paulo Villaça bebe água no bidê num hotel da Boca do Lixo..153 Figura 113 - O Bandido escreve "Merci" nas costas de uma de suas vítimas.........154 Figura 114 - Julio Calasso Junior faz uma ponta no filme. 155

Figura 115 - As feições rosto do Bandido são distorcidas quando o ator se aproxima da câmera. .155

Figura 116 - Cidadão algemado no poste na Boca do Lixo 157

Figura 117 - Prostituta com cliente usando cinta-liga. 157

Figura 118 - Lucho Gatica usando capa e óculos. 158

Figura 119 - Maquiagem da personagem Janete Jane. 158 


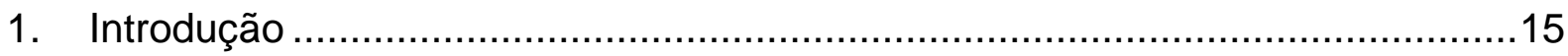

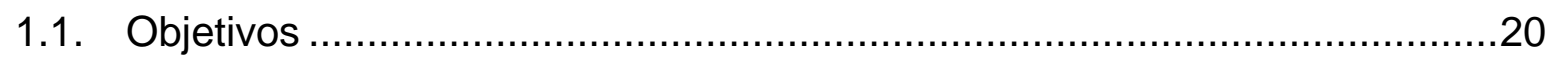

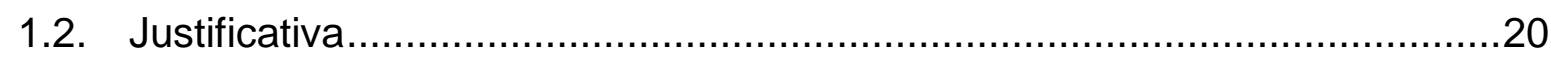

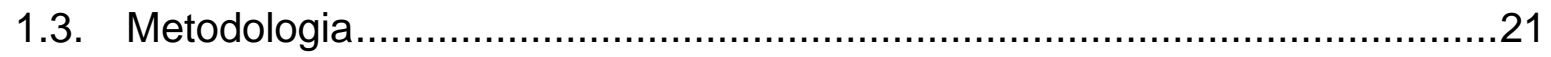

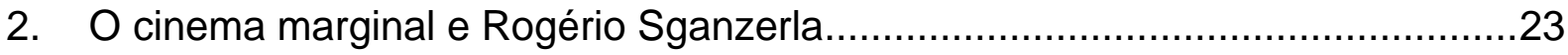

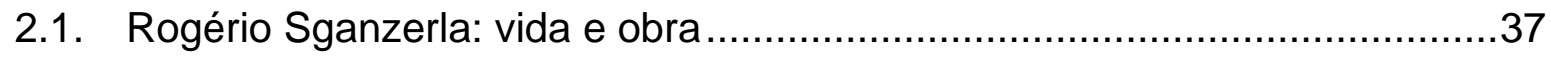

2.2. Aspectos sócio-político-culturais neste período ...............................47

2.3. Correntes estéticas que influenciaram este movimento ..........................57,

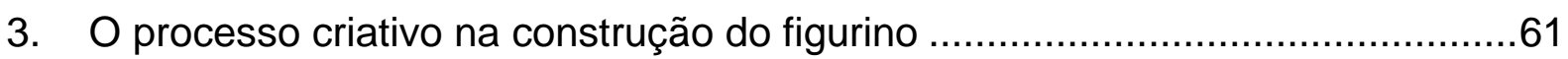

3.1. O processo criativo do figurino no Cinema Marginal de Rogério Sganzerla 63

4. Análise do figurino no filme "O Bandido da Luz Vermelha" .73

4.1. Os critérios utilizados para a análise dos figurinos do "Bandido da Luz

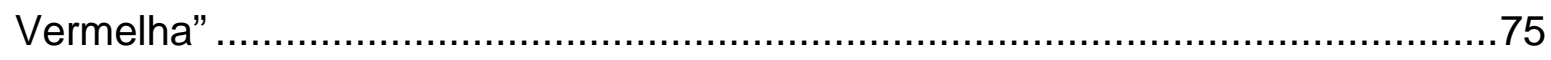

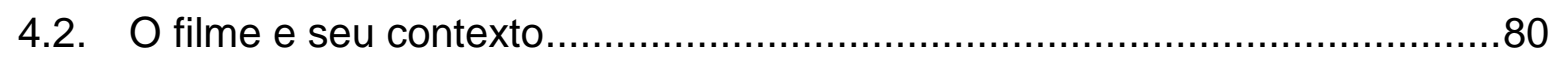

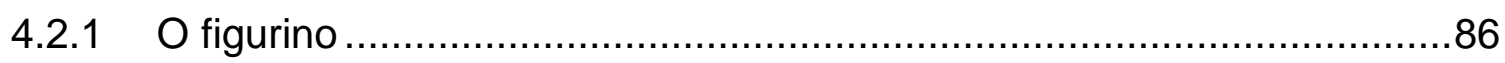

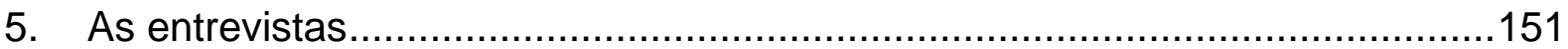

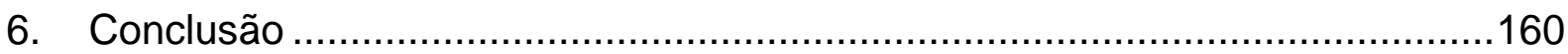

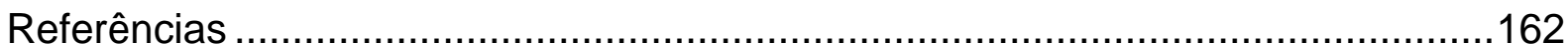




\section{Introdução}

O cinema brasileiro obteve um importante viés conceitual, desde as primeiras décadas do século XX. O filme "Limite" (1931), de Mário Peixoto, entre outros, criou um diálogo pleno entre as teorias desenvolvidas pela vanguarda e a eficiência da prática desses conceitos na obra.

A partir da década de 40, o cinema brasileiro passa a ter destaque com os filmes produzidos principalmente pela Companhia Cinematográfica Vera Cruz, fundada em 1949. Empresários e banqueiros paulistas associam-se à produtora, seduzidos pela ideia de tratar temas brasileiros com a técnica e a linguagem do cinema americano.

As Chanchadas, filmes onde predominavam o humor ingênuo, burlesco, de caráter popular, foram comuns no Brasil entre as décadas de 1930 e 1960. A produtora carioca Atlântida Cinematográfica, fundada em 1941, foi a grande responsável pelo sucesso das Chanchadas e a pioneira em adotar os temas carnavalescos em forma de musicais.

Apesar das produções exprimirem muito da realidade nacional e do caráter do homem brasileiro, eram vistas como produto mimético do cinema hollywoodiano, sem inovação artística, descompromissada com a realidade nacional, e muito menos fomentadora de qualquer tipo de conscientização do público. Sua linguagem era considerada reacionária por não retratar verdadeiramente o homem brasileiro e nem o ambiente do país, submetendo o público à dependência cultural.

Nos anos 50, num momento histórico de grande relevância para o Brasil, um grupo de jovens intelectuais começa a discutir a ideia de se criar um cinema nacional, que construísse uma identidade político-cultural para o povo brasileiro. Em contraposição à Chanchada, eles lutavam para que o cinema nacional se tornasse uma das expressões da cultura brasileira, com foco na realidade econômica, social e cultural do país. Assim surge o Cinema Novo, que eclode na década de 60 e tem grande repercussão internacional (SIMONARD, 2003).

As novas inclinações realistas aparecem nos primeiros filmes dos cineastas Nelson Pereira dos Santos (1928) e Roberto Santos (1928-1987). Filmes engajados na aproximação das condições de vida do povo e muito penetrantes em seu 
universo, com experiências que refletem apropriações ou similaridades do Neorrealismo, do Cinema-Verdade e da Nouvelle Vague.

O Cinema Novo criticava a utilização formal dos filmes estrangeiros da Chanchada, sobretudo dos norte-americanos, e assimilava a estética neo-realista italiana $^{1}$ de Roberto Rossellini (1906-1977), Luchino Visconti (1906-1976) e Vittorio De Sica (1901-1974); e ainda a política dos "autores"2 de André Bazin, Jean-Luc Godard e François Truffaut no Cahiers do Cinéma e na Nouvelle Vague ${ }^{3}$ (SOUZA, 2009).

O cineasta baiano Glauber Rocha (1939-1981), foi um dos principais representantes do Cinema Novo. Seu cinema impressionou diretores e críticos europeus. O filme "Deus e o Diabo na terra do sol" (figura 1) era repleto de uma beleza selvagem, que excitou a todos com a possibilidade de um grande cinema nacional. Era a tentativa de superar o estágio primitivo do cinema comercial brasileiro.

Figura 1 - Cena do filme: "Deus e o Diabo na terra do sol" (1964).

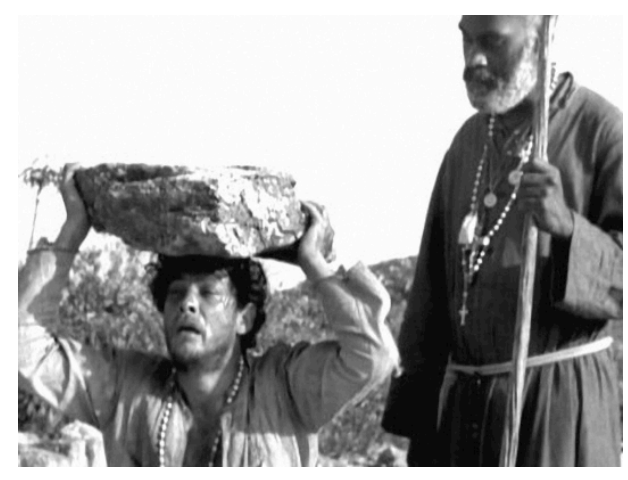

Fonte: http://mycinemateque.wordpress.com/2011/09/18/deus-e-o-diabo-na-terra-do-sol/

Acesso em 16/12/2012

No final da década de 60 surge o Cinema Marginal, à margem da sociedade de consumo e das grandes produções; são fitas de baixo orçamento, simples, que

\footnotetext{
${ }^{1}$ Estética neo-realista italiana: movimento cultural surgido na Itália ao final da segunda guerra mundial. Um cinema engajado politicamente, revolucionário por ser profundamente antifascista. $\mathrm{O}$ neo-realismo deu voz ao homem comum do povo.

${ }^{2}$ Política dos "autores": Termo criado pelos jovens críticos cinematográficos da revista "Cahiers du Cinéma" nos anos 50. O filme se assemelharia com quem o produzia, sendo uma obra de arte única e de expressão pessoal (o diretor é também o roteirista e o produtor).

${ }^{3}$ Nouvelle Vague: movimento artístico do cinema francês da década de 60 . Os filmes não tinham grande apoio financeiro e os jovens cineastas queriam transgredir as regras aceitas pelo cinema comercial. André Bazin (1918-1958), Jean-Luc Godard (1930) e François Truffaut (1932-1984) são seus principais representantes.
} 
abordam os temas insólitos e inesperados, analisam o homem e seus valores. Seus personagens são prostitutas, travestis, bandidos, homossexuais, drogados, degenerados, entre outros. Um cinema autoral, sem concessões, agressivo, capaz de chocar pela textura da imagem, pela violência dos gestos e pelo grotesco das feições (JOSÉ, 2007).

No Cinema Marginal existe um interesse pelo humor, e consequentemente, a revalorização da Chanchada, com uma fusão moderna de seus elementos. Alguns personagens caricatos ressurgem, principalmente, na obra do cineasta marginal Rogério Sganzerla, exemplificado na figura 2, onde o ator Jorge Loredo interpreta o personagem Zé Bonitinho / Aranha no filme "Sem essa Aranha".

Figura 2 - Cena do filme "Sem essa Aranha", dirigido por Rogério Sganzerla, 1970.

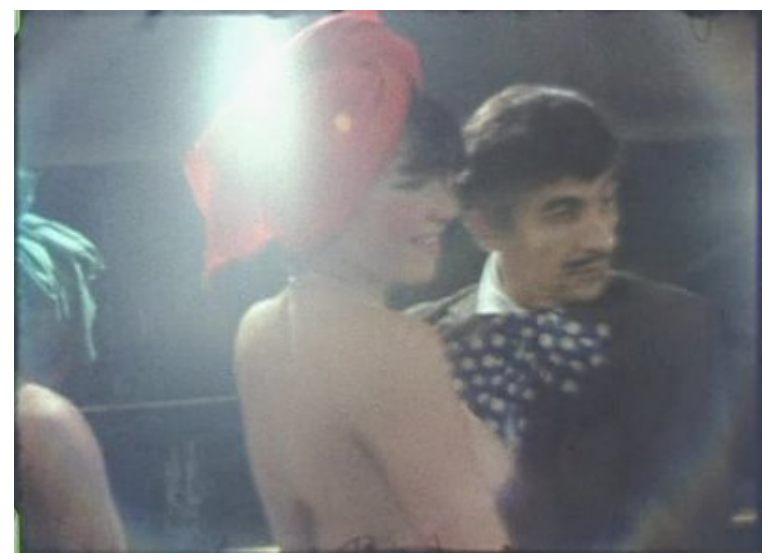

Fonte: http://www.quadradodosloucos.com.br/259/critica-sem-essa-aranha-sganzerla-1970/ Acesso em 16/12/2012

O fim do ciclo Marginal aconteceu no início dos anos 1970, com o endurecimento da ditadura militar, que levou boa parte dos cineastas a se exilar na Europa.

Os filmes Marginais possuem uma estética onde a beleza não é a palavra de ordem. Autores deste período denominam sua estética como "estética do lixo", uma referência talvez provocativa à "estética da fome" de Glauber Rocha. Um cinema que pretende experimentar, inovar, evoluir a linguagem cinematográfica e, ao mesmo tempo, agredir pela sua forma estilística, dificultando a compreensão do espectador (MORAES, 2010).

O estilo me causa horror e percebo que, quando escrevo, eu o pratico sempre. Se existe alguma coisa infernal e verdadeiramente maldita nestes 
tempos, é o deter-se artisticamente sobre as formas, em vez de agir como os supliciados que são levados ao fogo e que abençoam suas fogueiras. Mas cenários, figurinos, gestos e gritos falsos não substituirão jamais a realidade que esperamos (Artaud, apud VIANA, 2010, p.145).

Seus personagens são vestidos com roupas comuns, desgastadas, envelhecidas, sujas, desajeitadas, emprestadas de amigos, da equipe ou do próprio elenco, roupas que compõe um figurino.

O figurino, ou para alguns estudiosos o traje de cena, é aquele utilizado em qualquer cena artística, qualquer peça vestida dentro de uma produção, seja ela de teatro, dança, circo, cinema, televisão ou performance. Em qualquer um dos casos ele deve ser o mais apropriado possível dentro do contexto (PEREIRA, 2012).

Para a diretora de arte Vera Hamburguer, o figurino significa:

A caracterização de um personagem sobre a figura de um ator, o ponto ativo do quadro, o corpo que transpassa o espaço e o tempo e que a cada composição constrói novas sensações a partir dos contrastes visuais criados entre os pares, o fundo e a forma (HAMBURGUER, 2014, p.47).

Segundo Adriana Leite e Lisette Guerra:

O figurino representa um forte componente na construção do espetáculo, seja no cinema, no teatro ou na televisão. Além de vestir os artistas, respalda a história narrada como elemento comunicador: induz a roupa a ultrapassar o sentido apenas plástico e funcional, obtendo dela um estatuto de objeto animado. Percorre a cena no corpo do ator, ganha a necessária mobilidade, marca a época dos eventos, o status, a profissão, a idade do personagem, sua personalidade e sua visão de mundo, ostentando características humanas essenciais e visando à comunicação com o público (LEITE, GUERRA, 2002, p.62).

Parece uma contradição, mas esta é a árdua tarefa de um figurinista.

Figurinista tem que conhecer a fundo a história do personagem, pois o figurino tem que revelar a época em que se passa a trama, o perfil psicológico do personagem e sua posição dentro da estória. Além de conhecimentos específicos sobre a obra: o local onde são filmadas as cenas, o tipo físico dos atores e as orientações de luz e cor feitas pelo diretor da obra (BATISTTI, 2009, p.2).

O personagem é o objeto principal da narrativa, seguido do início ao fim do filme. Segundo Paulo Emílio Salles Gomes, o personagem cinematográfico é a junção do personagem novelístico, da obra literária, com a teatral. "Vamos, pois, afirmar que no filme evoluem personagens romanescas encarnadas em pessoas ou, 
se o preferirmos, personagens de espetáculo teatral que possuem mobilidade e desenvoltura como se estivessem num romance" (CANDIDO, 2009, p.112).

No cinema, assim como no teatro, os atores interpretam personagens. Porém a intimidade conquistada entre o espectador e o personagem é maior no cinema do que no teatro. No palco, temos sempre os personagens da cabeça aos pés. Na tela grande temos os detalhes, ora o corpo inteiro, ora a boca, o busto, os olhos, como na vida real.

O ator, vestido com o figurino e maquiado, representa a expressão plástica direta do personagem para o público. Fazer figurino é entender a vestimenta, seus aspectos sociais e culturais, e sua inserção no mundo do espetáculo. A escolha dos materiais, acessórios, modelagem, cores e texturas indica, além destes aspectos citados, as circunstâncias particulares ao momento em que o personagem vive.

O ator devidamente trajado é reconhecido a cada aparição, seu estilo pessoal é marcado, sendo compreendido em suas transformações. Ainda para Hamburguer, "O uso de cores e texturas também colabora na definição de seu papel na estrutura dramática e no jogo estabelecido com os demais personagens" (HAMBURGUER, 2014, p.47).

Um cinema que retrata o cotidiano, a realidade e o momento de um país, também possui figurinos com as mesmas características; estudar os figurinos do Cinema Marginal pode abrir novas perspectivas para conhecer o passado. Assim, concluímos que examinar materiais, cores, desenhos dos tecidos, forma e acessórios dos trajes torna possível uma completa compreensão da época na qual tais trajes eram usados.

\footnotetext{
E pelo fato da sociedade ocidental contemporânea pautar sua identidade cultural na abundância material por ela gerada, o design configura-se como uma das fontes importantes de informação sobre esta cultura, seja em estudos históricos, diagnósticos ou até prospectivos (SOUZA; BASTOS, 2014, p.5).
}

Esta pesquisa tem grande relevância ao documentar figurinos do cinema brasileiro na obra de Rogério Sganzerla, pois não existe um estudo desta natureza e, assim, comprova a importância dos trajes na obra cinematográfica e na construção dos personagens.

Através da coleta da memória dos participantes daquele momento, inicia-se uma reconstituição da história do figurino no cinema brasileiro no ciclo Marginal. É 
importante resgatar nomes e métodos de trabalho para a concepção destes figurinos num momento de grande destaque da história do cinema nacional, a fim de contribuir para a memória coletiva do Brasil.

\subsection{Objetivos}

O presente trabalho tem por objetivo analisar e documentar os figurinos criados para o cinema brasileiro na obra de Rogério Sganzerla, com foco no filme "O Bandido da Luz Vermelha", durante o período chamado de Cinema Marginal.

Para tanto, esta pesquisa prevê os seguintes objetivos específicos:

- Investigar o processo criativo da construção dos figurinos na obra de Rogério Sganzerla.

- Compreender a escolha dos trajes para a composição dos figurinos no filme "O Bandido da Luz Vermelha".

- Salientar a importância do figurino na obra cinematográfica.

\subsection{Justificativa}

Considerando o Cinema Marginal como um ciclo de grande criatividade do cinema brasileiro, ocorrido no período de 1968 a 1973, a análise dos figurinos no filme "O Bandido da Luz Vermelha", dirigido por Rogério Sganzerla e considerado um dos filmes mais expressivos durante este momento, torna-se relevante.

Explorar a maneira como os figurinos da obra do cineasta foram eleitos e inseridos na narrativa pode acrescentar conhecimento ao estudo da estética Marginal dentro do cinema brasileiro.

A partir do estudo dos figurinos no filme "O Bandido da Luz Vermelha", podese ampliar a compreensão da sociedade neste período e, desta maneira, iniciar um entendimento mais profundo do comportamento, desejos e anseios do indivíduo, aqui representados, pelos personagens.

Para isto, justifica-se a realização desta proposta, que pretende englobar o entendimento da estética Marginal, aplicada principalmente aos figurinos, e a 
representação cultural, psico e social de seus personagens a partir de seus trajes. Com base nas justificativas acima, entende-se que o estudo desta área traz benefícios para estudiosos e profissionais da moda e do meio cinematográfico e, preferencialmente, para a memória coletiva nacional.

\subsection{Metodologia}

O ponto de partida para esta pesquisa é a seleção bibliográfica. Inicia-se pela busca das principais características do cinema brasileiro, com foco no Cinema Marginal. É explorada a fortuna crítica sobre Rogério Sganzerla, vida e obra. Por fim, são investigados os métodos do processo criativo de um figurino dentro da produção cinematográfica.

No capítulo 2 são apresentadas as principais características do Cinema Marginal face aos acontecimentos sócio-político- culturais deste período e os pontos pertinentes na obra de Rogério Sganzerla.

A partir de informações das entrevistas realizadas para este trabalho, o capítulo 3 expõe o início do conhecimento sobre o processo criativo do figurino no ciclo Marginal.

Foram realizadas entrevistas com profissionais participantes ou ligados à obra do cineasta em pesquisa, como uma forma de resgatar o método de trabalho utilizado pelos responsáveis pela escolha dos figurinos. Poucas pessoas estão disponíveis. Assim, entre os indivíduos relevantes desse período, foi possível entrevistar:

- Helena Ignez - diretora de cinema, musa do Cinema Marginal, viúva de Rogério Sganzerla e atriz do filme analisado nesta pesquisa.

- Carlos Ebert - Câmera e diretor de fotografia do filme "O Bandido da Luz Vermelha".

- Julio Calasso Junior - diretor de cinema e produtor executivo do filme analisado.

O capítulo 4 analisa os figurinos do filme "O Bandido da Luz Vermelha" (Rogério Sganzerla. Brasil, 1968, 35mm, p\&b) com o objetivo de identificar as 
principais características e informações sobre os personagens e influências do período.

Informações complementares, obtidas através das entrevistas realizadas para esta pesquisa, foram acrescentadas no capítulo 5 e expostas de maneira a iniciar um entendimento de como foi concebido o figurino do filme "O Bandido da Luz Vermelha".

Com este material será possível levantar informações e documentar o figurino no cinema brasileiro, dentro do recorte proposto. 


\section{O cinema marginal e Rogério Sganzerla}

No final dos anos 60 e meados dos anos 70, um período de forte tensão política no país, surge um dos mais marcantes e polêmicos movimentos do cinema brasileiro: o Cinema Marginal. Um grupo de jovens realizadores rompe com os padrões convencionais da narrativa e estética. À margem da indústria cultural, criam um cinema de resistência e de pressão artística. Para o entendimento da significação do Cinema Marginal dentro do panorama do cinema brasileiro, estará sempre presente a conotação pejorativa inerente ao fato de estar à margem.

Nos anos de chumbo, em plena ditadura militar, estes cineastas faziam seus filmes nas situações mais adversas. Filmes, na sua maioria, pouco assistidos e debatidos; filmes que incomodavam e chocavam os ouvidos - o Cinema Marginal também é reconhecido como cinema de histeria, porém filmes que deixaram uma grande contribuição criativa para o cinema nacional (PUPPO, 2001).

O primeiro filme a ser incluído no movimento foi "A Margem" (1967), de Ozualdo Candeias (1922- 2007), daí a expressão Cinema Marginal. Mas outras denominações também foram dadas a este período, tais como, Udigrúdi (corruptela do Cinema Underground Americano, movimento que rompia com o cinema clássico, caracterizando-se pela livre criação), Cinema Marginalizado, Cinema de Invenção (a mais recente, criada por Jairo Ferreira - crítico, cineasta, ator, fotógrafo de cena e jornalista). Rogério Sganzerla e Júlio Bressane (cineasta e sócio de Sganzerla na produtora Belair) discordavam já na época da expressão Cinema Marginal, pois a intenção deles não era fazer um cinema que ficasse à margem dos circuitos exibidores (como no Underground Americano). Ao contrário, as obras foram, sim, marginalizadas pelos circuitos e pela censura.

Para Jairo Ferreira, segundo Fernão Ramos, a história deste movimento teria começado assim:

\footnotetext{
Em 1967, em São Paulo, quando (...) Ozualdo Candeias deu à luz a um filme não considerado de imediato que eu ousei considerar o filme mais deflagrador no Cinema Brasileiro desde Limite. Como o filme não era Cinema Novo nem chanchada, passou a ser chamado de Cinema da Boca do Lixo (...) um rótulo que nasceu dos bate-papos entre jovens cineastas que frequentavam o pedaço a partir do ano seguinte: Carlos Reichenbach, João Callegaro, João Batista de Andrade, João Silvério Trevisan, Sebastião de Souza, José Mojica Marins, Rogério Sganzerla, Candeias e eu, é claro (RAMOS, 1987, p.55).
} 
Para Ramos (1987), apesar do filme "A Margem" ser de 1967 (figura 3), podese fazer uma demarcação histórica do Cinema Marginal de 1968 a 1973. O ano de 1968 foi escolhido por constituir uma data histórica com acontecimentos marcantes no Brasil e em todo o mundo, e quando começaram a ser produzidos os primeiros filmes considerados marginais, tais como: "Câncer", de Glauber Rocha; "Hitler no III Mundo", de José Agrippino de Paula; "Jardim de Guerra”, de Neville D’Almeida; e "O Bandido da Luz Vermelha", de Rogério Sganzerla. A data de 1973 parece definir o fim da produção histórica do Cinema Marginal enquanto grupo relativamente coeso, ainda com alguns filmes feitos no exterior, durante o exílio voluntário a que foram sujeitos grande parte dos cineastas marginais. Além disso, o momento histórico já é outro e a força propulsora, que na virada da década havia lançado a produção marginal, já havia cessado em 1973.

Figura 3 - Cena do filme "A Margem”, 1967, de Ozualdo Candeias.

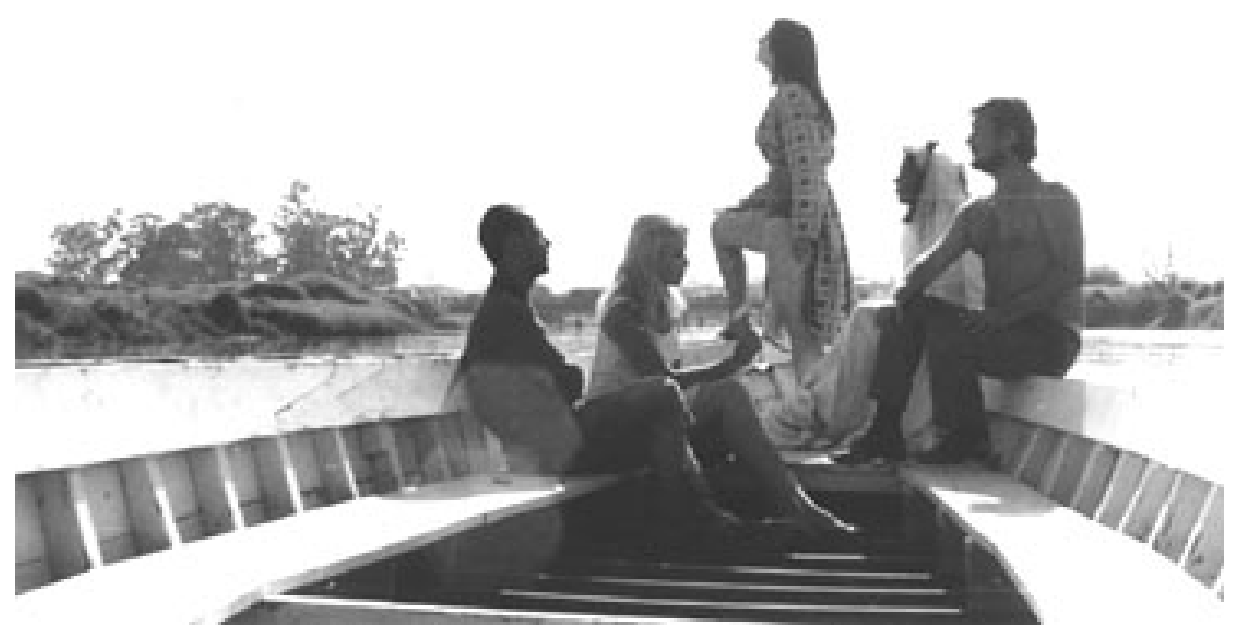

Fonte: RAMOS, 1987.

Além dos cineastas citados no parágrafo anterior, outros nomes podem ser incluídos como os principais representantes deste período: Andrea Tonacci, José Mujica Marins, João Batista de Andrade, João Callegaro, Luís Rosemberg Filho, Carlos Reichenbach, entre outros. Na figura 4, foto registrada pelo cineasta Ozualdo Candeias, pode-se observar os cineastas Carlos Reichenbach e Rogério Sganzerla. 
Figura 4 - Os cineastas Carlos Reichenbach e Rogério Sganzerla no início dos anos 70 na Boca do Lixo, em foto de Ozualdo Candeias.

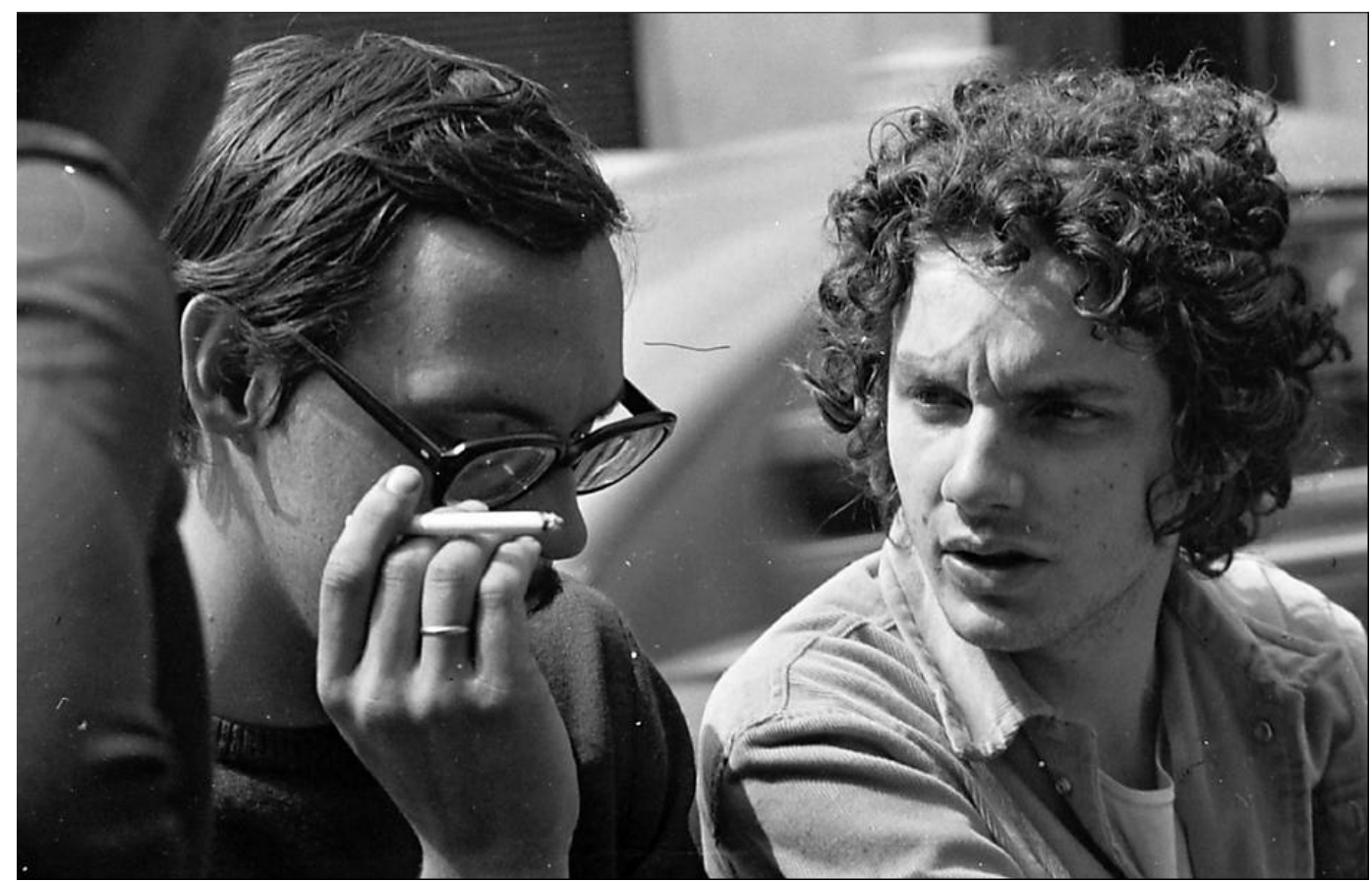

Fonte: http://fotografia.folha.uol.com.br/galerias/20983-boca-do-lixo\#foto-340467 Acesso em 18/12/2015

As expressões modernas no cinema brasileiro eclodem num espaço-tempo conjunto às instabilidades da década de 60. O cinema culto dos anos 60-70 é pensado como Cinema Novo e Cinema Marginal. Os marginais faziam filmes que ignoravam a censura e o mercado, num momento caracterizado por violentos mecanismos institucionais, que visavam garantir a "ordem", e paralelo a isso acontecia um crescimento significativo dos meios de comunicação, com a decorrente necessidade de expansão do mercado e produção cinematográfica.

O Cinema Marginal começou em São Paulo na Boca do Lixo e teve ramificações descentralizadas no Rio, na Bahia e em Minas Gerais. A Boca ficava na região central da cidade onde se localizavam produtoras e distribuidoras de cinema, na Rua do Triumpho e suas imediações. Existia uma subindústria de cinema que se formava em torno da Boca do Lixo. Nos anos 70 a produção chegava a cem filmes/ano e ocupava um terço das salas do país (PUPPO, 2001). Esta área também era, e ainda é, conhecida por ser zona de prostituição e tráfico de drogas.

Ozualdo Candeias registrou algumas imagens da Boca do Lixo naquele momento efervescente como pode-se observar nas figuras 5, 6 e 7. 
Figura 5 - O Bar Soberano, ponto de encontro de diretores, atores, produtores e outros ligados à indústria cinematográfica, localizado na Boca do Lixo.

Foto de Ozualdo Candeias.

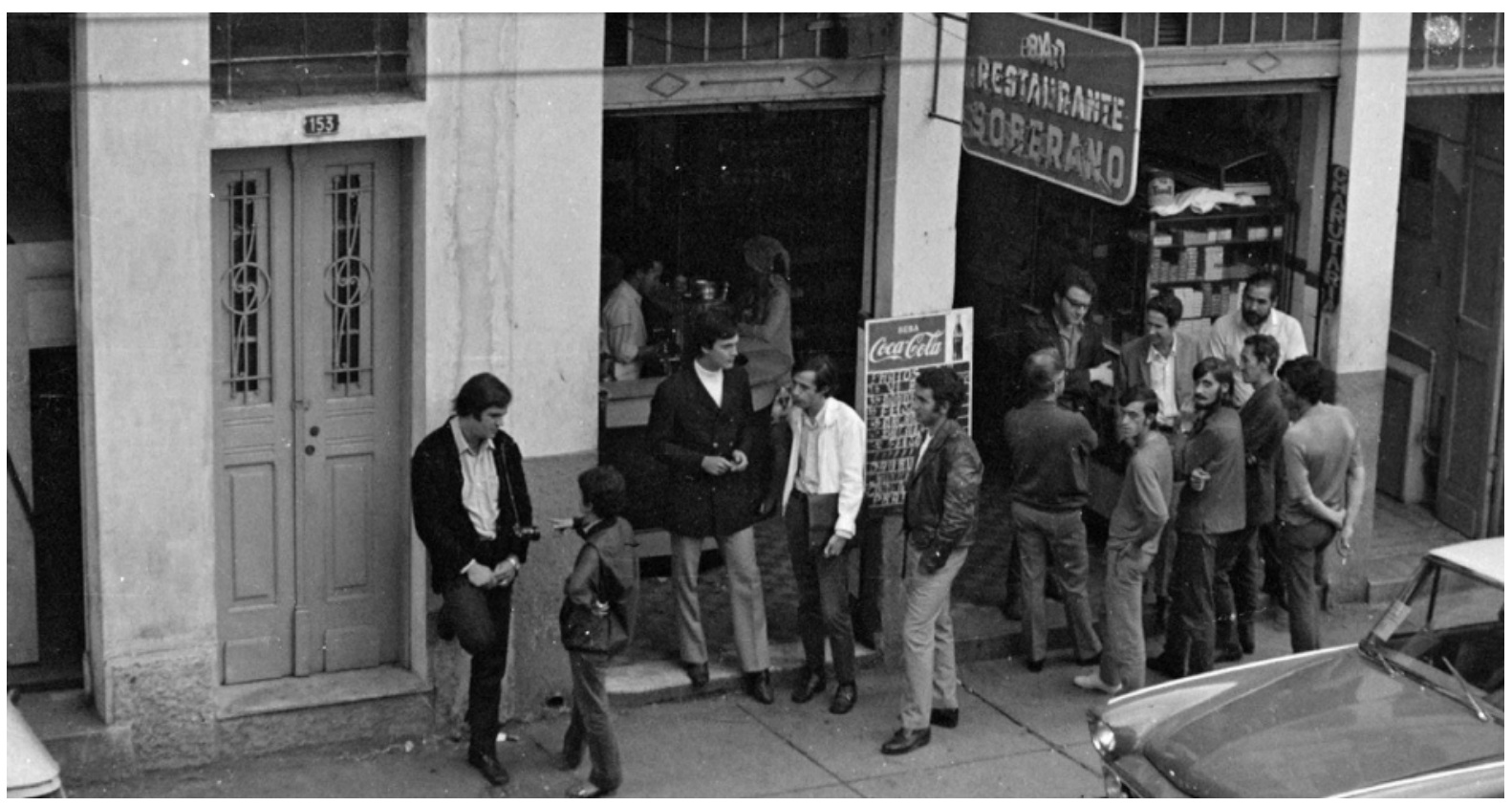

Fonte: http://cinema.uol.com.br/album/2012/05/12/veja-imagens-que-fazem-parte-da-exposicaoozualdo-candeias---rua-do-triumpho.htm\#fotoNav=3 Acesso em 18/11/2015.

Figura 6 - A foto mostra o transporte de filmes na região da Boca do Lixo. Foto de Ozualdo Candeias.

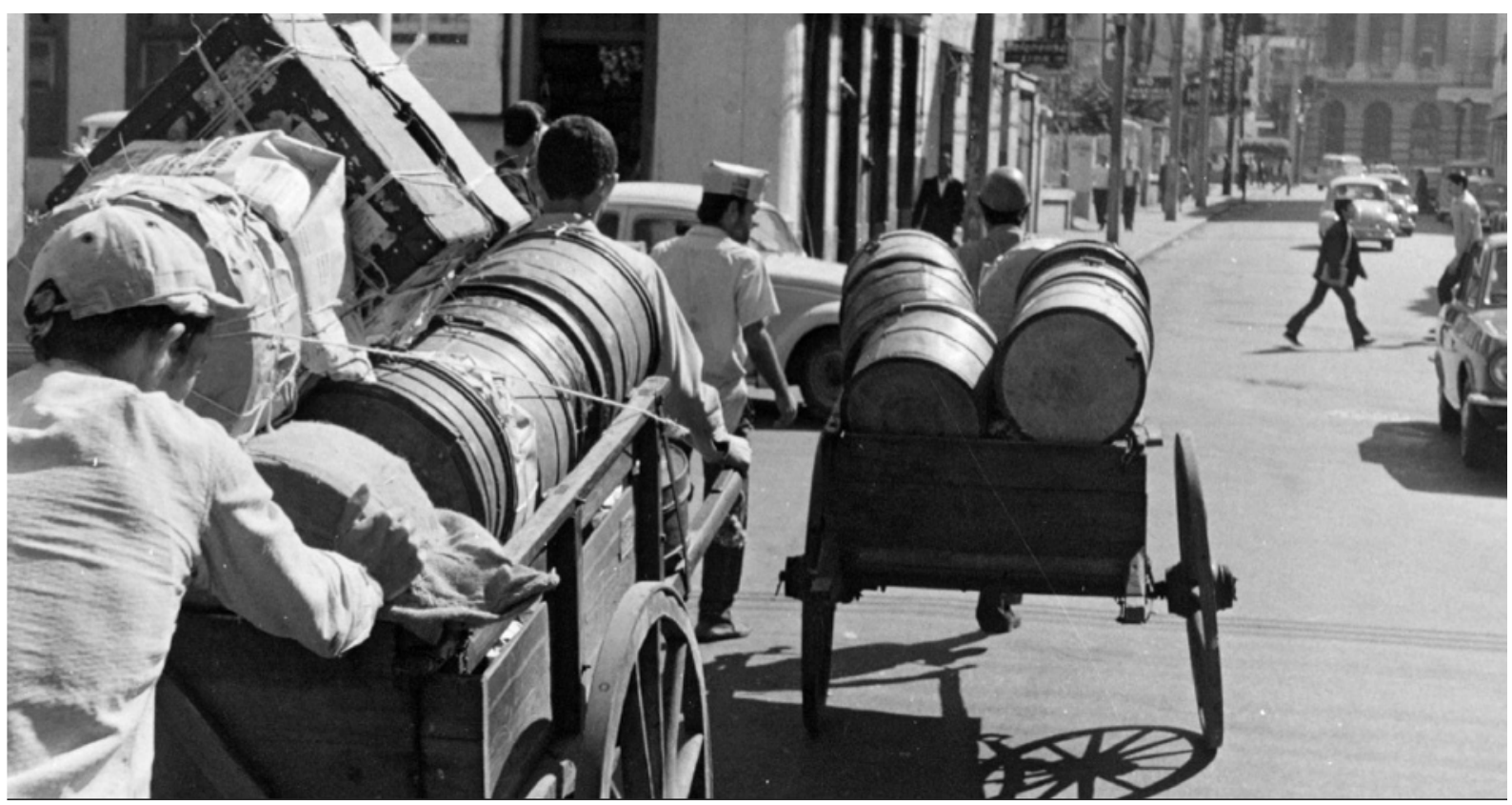

Fonte: http://cinema.uol.com.br/album/2012/05/12/veja-imagens-que-fazem-parte-daexposicao-ozualdo-candeias---rua-do-triumpho.htm\#fotoNav=12 Acesso em 18/11/2015. 
Figura 7 - Atriz não identificada se exibe para diretores e produtores em foto do início dos anos 70 na Boca do Lixo. Foto de Ozualdo Candeias.

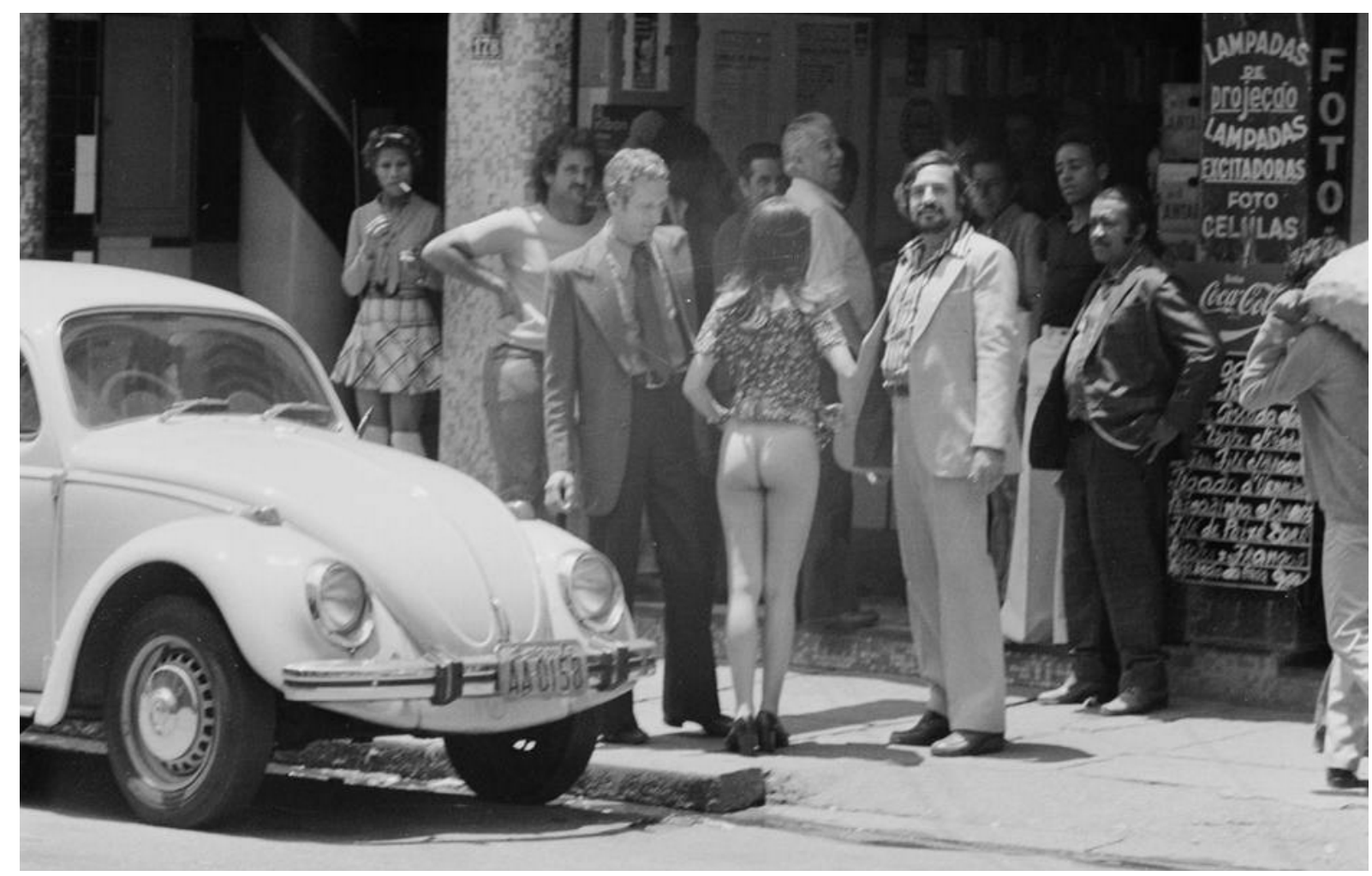

Fonte: http://fotografia.folha.uol.com.br/galerias/20983-boca-do-lixo\#foto-340470 Acesso em 18/11/2015.

No início do ciclo Marginal, a oposição entre Cinema Novo e Cinema Marginal era bem menos acentuada. Rogério Sganzerla e Júlio Bressane deixavam claro sua admiração pela obra dos cinemanovistas Paulo César Saraceni e Glauber Rocha. O que o Cinema Marginal rejeitava era o cinema de espetáculo para o qual o Cinema Novo se encaminhava, com filmes que deslumbravam o público com atores conhecidos e em cores.

Tanto para o Cinema Novo como para o grupo de cineastas do Cinema Marginal, havia o exercício de uma liberdade de estilo diante ao cinema mais vigente. Os cinemanovistas interpretavam esta liberdade dentro dos padrões do gênero "cinema de arte" do meio da década, cinema moderno dos grandes autores que tinham atenção do mercado internacional, tais como Godard, Fellini, Antonioni, Bertolucci e Renais. O Underground norte-americano, versão mais radical da vanguarda, era excluído do primeiro grupo, e associado aos marginais, que defendiam a experimentação com teor agressivo e "ilegibilidade" (XAVIER, 1993).

O Cinema Novo era a favor de uma interligação entre o "produtor independente" (o autor) e a produção, visando o mercado. Este era o cinema de 
espetáculo ligado a esquemas industriais de produção, ao qual o Cinema Marginal divergia e se deslocava imperceptivelmente para fora, iniciando uma oposição (RAMOS, 1987).

\footnotetext{
É claro que críticos e cineastas já destacaram pontos de contato entre os dois movimentos. Por exemplo, os baixos orçamentos na fase inicial do Cinema Novo e no Cinema Marginal. Ou a noção de autor, introduzida no Brasil pelo Cinema Novo e herdada pelo Cinema Marginal (PUPPO, 2001, p.12).
}

Fernão Ramos destaca a dimensão da distância entre os dois grupos num artigo escrito por Glauber Rocha (um dos mais significativos representantes do Cinema Novo), intitulado "Udigrúdi: uma velha novidade". Glauber ataca os jovens cineastas que estão despontando num caminho que parece trazer alguns problemas de consciência para o Cinema Novo. "Os jovens cineastas Tonacci, Sganzerla, Bressane, Neville e outros de menor talento levantaram-se contra o Cinema Novo, anunciando uma velha novidade: cinema barato, de câmera na mão e ideia na cabeça". Ramos concorda tratar-se de uma "velha novidade", porém é justamente por ser velha, esquecida e distante da prática do Cinema Novo, que se torna um polo conflitante (RAMOS, 1987, p.27).

Para Jean-Claude Bernadet, no texto "Cinema Marginal?" do livro "Cinema Marginal brasileiro e suas fronteiras" (PUPPO, 2001), classificar tais filmes dentro de um sistema de categoria, tem o efeito de promover semelhanças e afinidades entre filmes e diretores, em detrimento de diferenças e particularidades e também de outras afinidades.

Bernadet, em sua obra "Brasil em tempo de cinema", escrita em meados da década de 60, ainda aponta que o Cinema Novo, embora pretendesse a representação do povo, acaba por apresentar "uma classe média à cata de raízes e que quer representar na tela o seu marginalismo" (BERNADET, 1966, p.38). Os filmes de classe média deveriam retratar o povo e não o universo marginalizado da classe média.

Por outro lado, Ruy Gardnier destaca que, enquanto os cinemanovistas tentavam entender o fenômeno da seca e arriscavam o retirante no mito brasileiro por excelência, Rogério Sganzerla experimenta o que é o fenômeno urbano (GARDNIER, sd). 
Antes disto, porém, é importante ressaltar que o cineasta Luiz Sergio Person mostrou a metrópole no filme "São Paulo S.A" (1965), a cidade de onde vinha tanto o realizador quanto o público, exibindo o lado mesquinho, conservador, ambicioso de uma classe média e a essência do cotidiano paulistano (MORAES, 2010).

O grupo Marginal, de certa forma, recusava "a seriedade da alta arte" com uma "atitude pop", como cita Cláudio da Costa, segundo Robert Stam e Randal Johnson “(...) enquanto a cultura popular que interessava ao Cinema Novo era extensamente rural e literária, o underground está mais interessado na cultura popular urbana e especialmente o mass-media" (COSTA, 2000, p.103).

O personagem principal no filme "O Bandido da Luz Vermelha", de Rogério Sganzerla, diz que quando não se pode fazer mais nada, a gente "avacalha". Inácio Araújo no texto "No meio da tempestade" cita que este "avacalho" seria uma senha para o cinema nacional diante da impotência perante os estrangeiros, os exibidores e o mundo em geral. Neste momento, o urbano era a essência, e o modo de agir era o banditismo, a contravenção (PUPPO, 2001).

Segundo Rogério Sganzerla (2001) no texto "Um filme é um filme", de 1964, o personagem do cinema moderno é observado de longe, sem romantismo e podendo ser desmitificado. É o anti-herói típico do pós-guerra e da guerra fria, nu diante da câmera.

A manifestação coletiva, presente no Cinema Novo, agora era individual, frágil, inútil. A última frase do protagonista do filme "O Bandido da Luz Vermelha", "Sozinho a gente não vale nada, e daí?", demonstra esse sentimento. Em entrevista, Carlos Ebert comenta que Rogério Sganzerla terminou o filme com a frase "Sozinho a gente não vale nada", e no dia seguinte ele voltou ao estúdio de gravação e completou a frase com "e daí?", pois ele temia ser interpretado "como um chamado", uma política convencional que o autor não gostava (EBERT, 2013).

O Cinema Marginal cria um espaço ficcional onde alterna a "curtição" e o "horror", mas não deixa de ter como referência a própria classe média, os próprios produtores dos filmes, os seus horrores, suas angústias e seus prazeres. A proclamação de uma suposta sexualidade, livre de pecados e de culpas, é um dos pontos centrais da ideologia deste cinema.

(...) Este procedimento, que atrás denominamos de "curtição" tem um pouco de antropofagismo característico do tropicalismo na medida em que deglute esteticamente, sem preconceitos, a totalidade das representações que 
cercam o artista, para depois devolvê-lo numa forma estética que tem algo a lembrar um procedimento de colagem (RAMOS, 1987, p.41).

O improviso considerado uma aversão pela mentalidade profissional, esteve muito presente no Cinema Marginal. O roteiro não é o filme pronto, e a filmagem, montagem e sonorização não se limitam ao que era previsto no script. Segundo Bernadet, o improviso é um filme sendo criado durante a sua elaboração (PUPPO, 2001).

Rogério Sganzerla fala sobre o improviso no seu texto "Noções de Cinema Moderno", de 1965: "A improvisação é um processo arriscado, exige muito do diretor, mas oferece possibilidades ilimitadas. Constitui justamente a valorização do instante presente e o cinema é 'a arte do presente" (SGANZERLA, 2001, p.19).

Carlos Ebert, câmera do filme "O Bandido da Luz Vermelha", destaca em entrevista que, para ele o filme, às vezes dá uma impressão errada quanto ao improviso. No filme, os parâmetros eram ensaiados, existia uma marcação e era sabido exatamente o que o diretor Rogério Sganzerla queria. Porém dentro desta marcação, a câmera e a performance do Paulo Villaça, intérprete do Bandido, eram muito livres (EBERT, 2013).

Julio Calasso Junior, produtor do filme "O Bandido da Luz Vermelha", também comenta em entrevista concedida para esta pesquisa, que existia um roteiro para o filme chamado por ele de "roteiro de ferro", o qual Rogério Sganzerla seguia página por página. Porém, o diretor tinha sensibilidade suficiente para entender onde isso tudo que ele queria estava inscrito naquele momento que as coisas estavam acontecendo (CALASSO, 2015).

Para a crítica da época, a palavra "irracionalidade" era comumente atribuída aos filmes feitos pelos jovens cineastas marginais no início da década de 70 . Talvez porque seja um dos poucos adjetivos encontrados para refletir a perplexidade destes críticos diante de obras que desviavam totalmente dos padrões convencionais da representação.

Alguns temas são constantes nas produções marginais: consumo de drogas; sexualidade livre e fora dos padrões institucionais; renúncia aos valores tradicionais, tais como a família, a propriedade e a carreira profissional; exaltação do "não trabalho" e da preguiça; aparência suja e descuidada, desprezando valores de comportamento, entre eles a maneira de se vestir; escolha de uma vida alternativa 
em lugares isolados; reivindicações relativas a grupos marginais, tais como os negros, índios, mulheres, homossexuais, entre outros.

No plano estético, segundo Rubens Machado Jr no texto "Passos e descompassos à margem", existem muitas direções a investigar e estilos a caracterizar. Cita como exemplo provocativo a frase do pensador catalão Eugenio d'Ors: "Sempre que encontramos reunidos num só gesto, várias intenções contraditórias, o resultado estilístico pertence à categoria do Barroco" (PUPPO, 2001, p.21).

A estética do Cinema Marginal é marcada pelo ruim, o sujo, o lixo, aspectos que ganham toda a dimensão quando são incluídos dentro do quadro de humor debochado e irônico da palavra "curtição".

A abjeção constitui um momento privilegiado da narrativa marginal. O nojo, 0 asco, a imundice, a porcaria, enfim todo o universo "baixo" que nega a representação do "nobre" compreende a narrativa deste ciclo. Outra característica da narrativa marginal é sacrificar o desenvolvimento linear da ação para se fixar demoradamente numa paisagem, num rosto, num berro, ou até mesmo num vômito.

No filme "Sem essa Aranha" (1970) de Rogério Sganzerla, a personagem da atriz Helena Ignez é uma exacerbada em vômitos. Em várias sequências, a personagem enfia o dedo na garganta e provoca o vômito, vide figura 8, imagem bastante comum na narrativa Marginal.

Figura 8 - A atriz Helena Ignez em cena do filme "Sem essa Aranha" (1970)

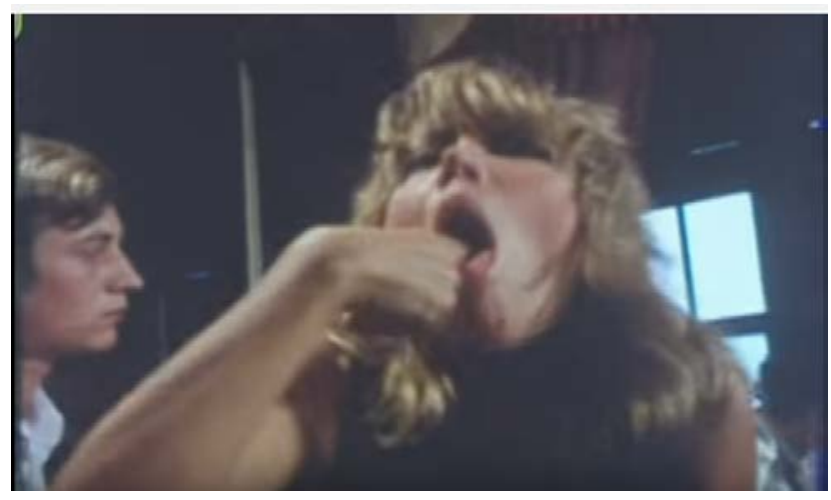

Fonte: Fotograma do filme

Algumas imagens são constantes nos filmes marginais, como quando o personagem enche a boca de comida, acima de sua capacidade de mastigar, e deixa a comida escapar pelos cantos da boca, "deglutição aversiva". Ou ainda, a 
"baba de sangue", muito recorrente na estética marginal, como mostra a figura 9, no filme "A família do barulho", de Júlio Bressane.

Figura 9 - Helena Ignez no filme: "A família do barulho", de Júlio Bressane, 1970.

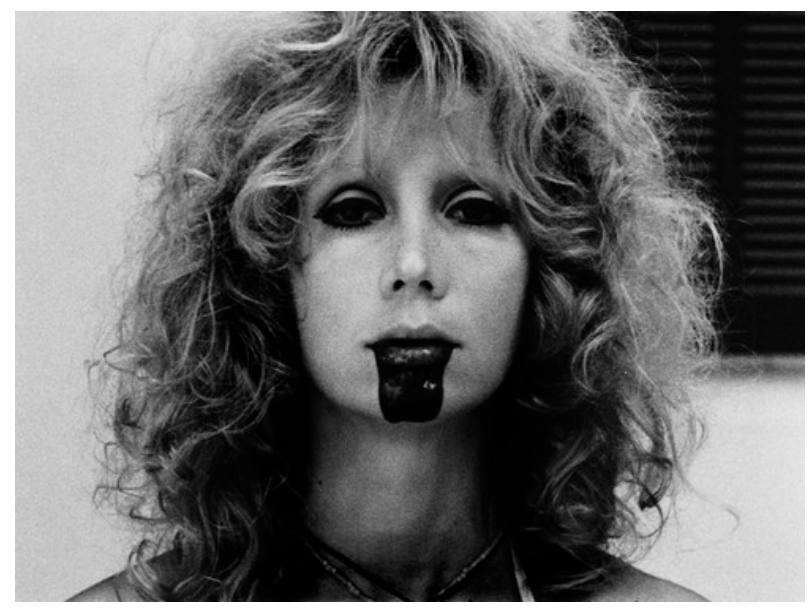

Fonte: RAMOS, 1987

É possível reconhecer uma cena de "deglutição aversiva", bastante comum na estética marginal, no filme "O Bandido da Luz Vermelha", quando o protagonista come uma espiga de milho no cinema, abaixo na figura 10.

A deglutição aversiva envolve também a ingestão de detritos, geralmente apanhados em depósitos de lixo. Outro exemplo encontrado no "Bandido" é quando 0 ator Paulo Villaça bebe tinta, vide figura 11.

Longos e exasperados berros também aparecem como o significante característico do horror neste movimento. Eles interrompem o desenvolvimento linear da narrativa. O filme "O Bandido da Luz Vermelha" apresenta mais de uma cena com esta característica. Uma delas é um plano geral onde é possível ver o carro do Bandido deslizando na areia da praia da Baixada Santista, enquanto escuta-se um berro constante do protagonista, como se não houvesse fim naquela gritaria.

A questão da marginalidade - presente de maneira difusa na história do cinema brasileiro através da produção "independente", "experimental" e outras atinge neste período um caráter de grande significação. O Cinema Marginal teve presença marcante, influenciando um grande número de autores das mais diversas origens, onde se notam traços de uma estética característica do grupo analisado. 
Figura 10 - O ator Paulo Villaça em cena de "deglutição aversiva" no filme "O Bandido da Luz Vermelha", 1968.

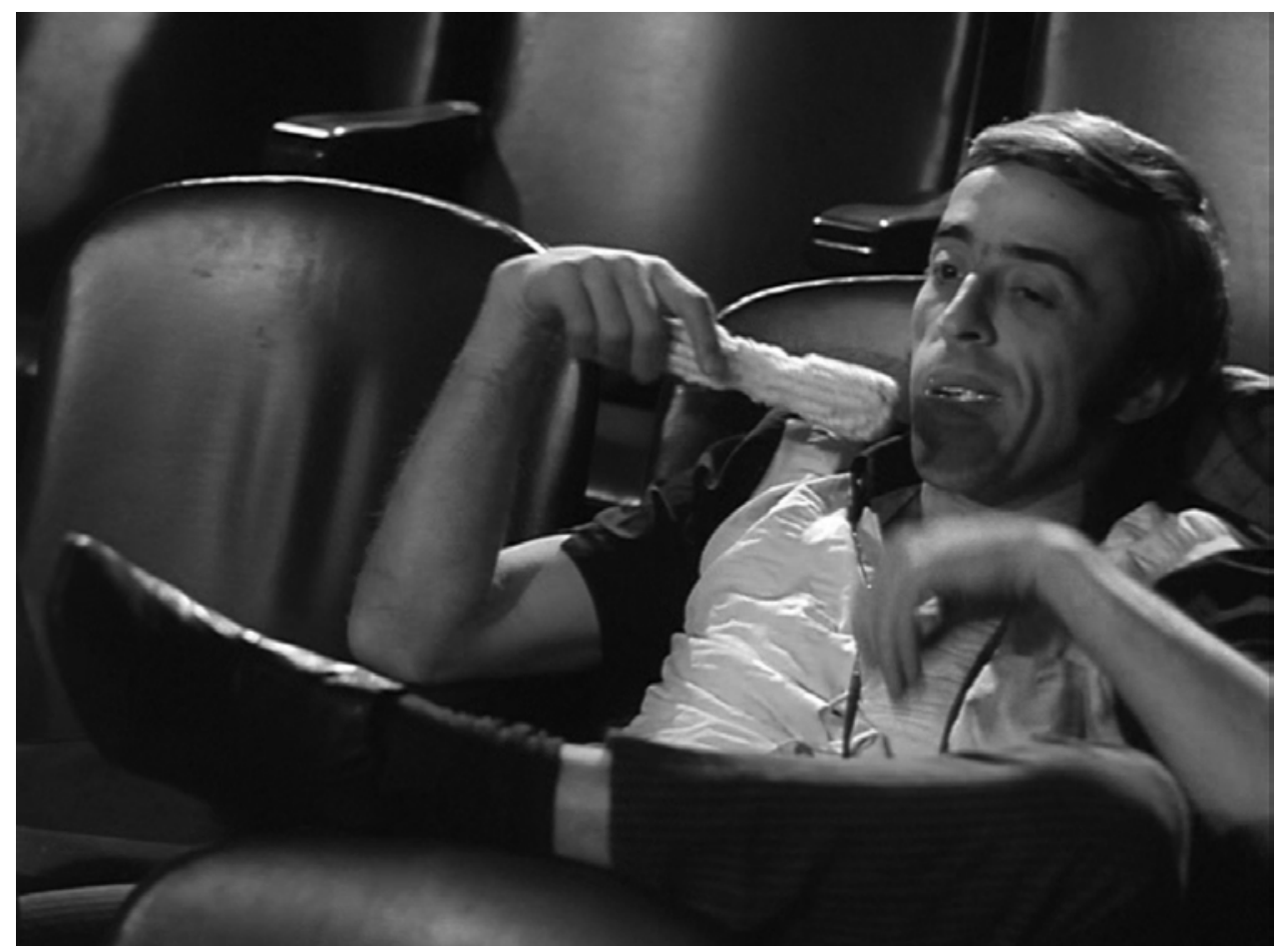

Fonte: Fotograma do filme

Figura 11 - Paulo Villaça após beber tinta em cena do filme "O Bandido da Luz Vermelha", 1968.

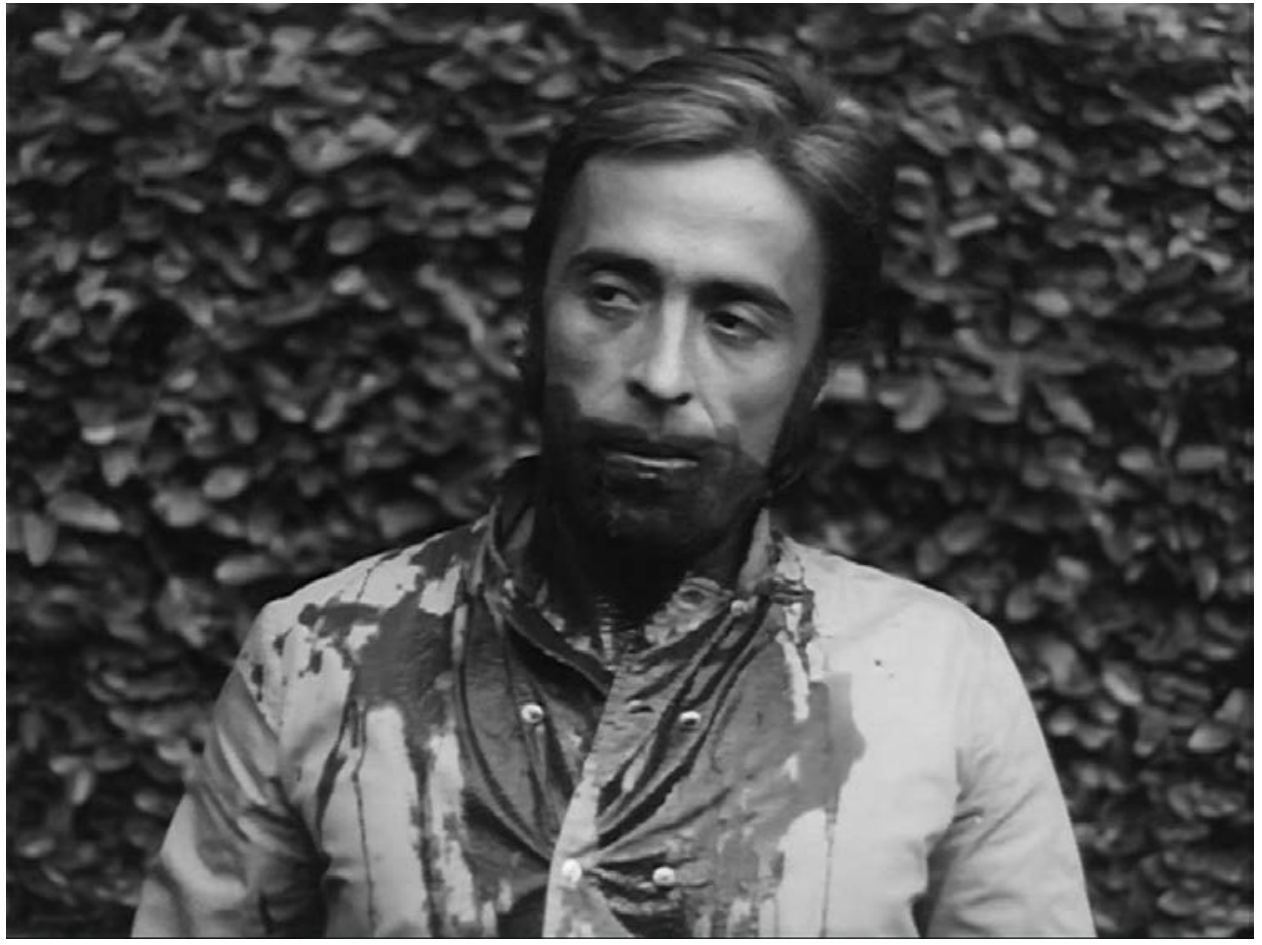

Fonte: Fotograma do filme. 
Rogério Sganzerla, grande expoente deste movimento, começa produzindo "O Bandido da Luz Vermelha", em 1968, e logo em seguida faz "A Mulher de Todos" (1969), ambos produzidos e distribuídos pela Boca do Lixo. Estes filmes tiveram um relativo sucesso de público e bom retorno financeiro. Posteriormente, o cineasta e Júlio Bressane se juntam para criar a produtora Belair. Observa-se na figura 12 Sganzerla, Bressane e a equipe da Belair.

Figura 12 - Rogério Sganzerla, primeiro à esquerda, Júlio Bressane, quarto a partir de Rogério, com a equipe da Belair.

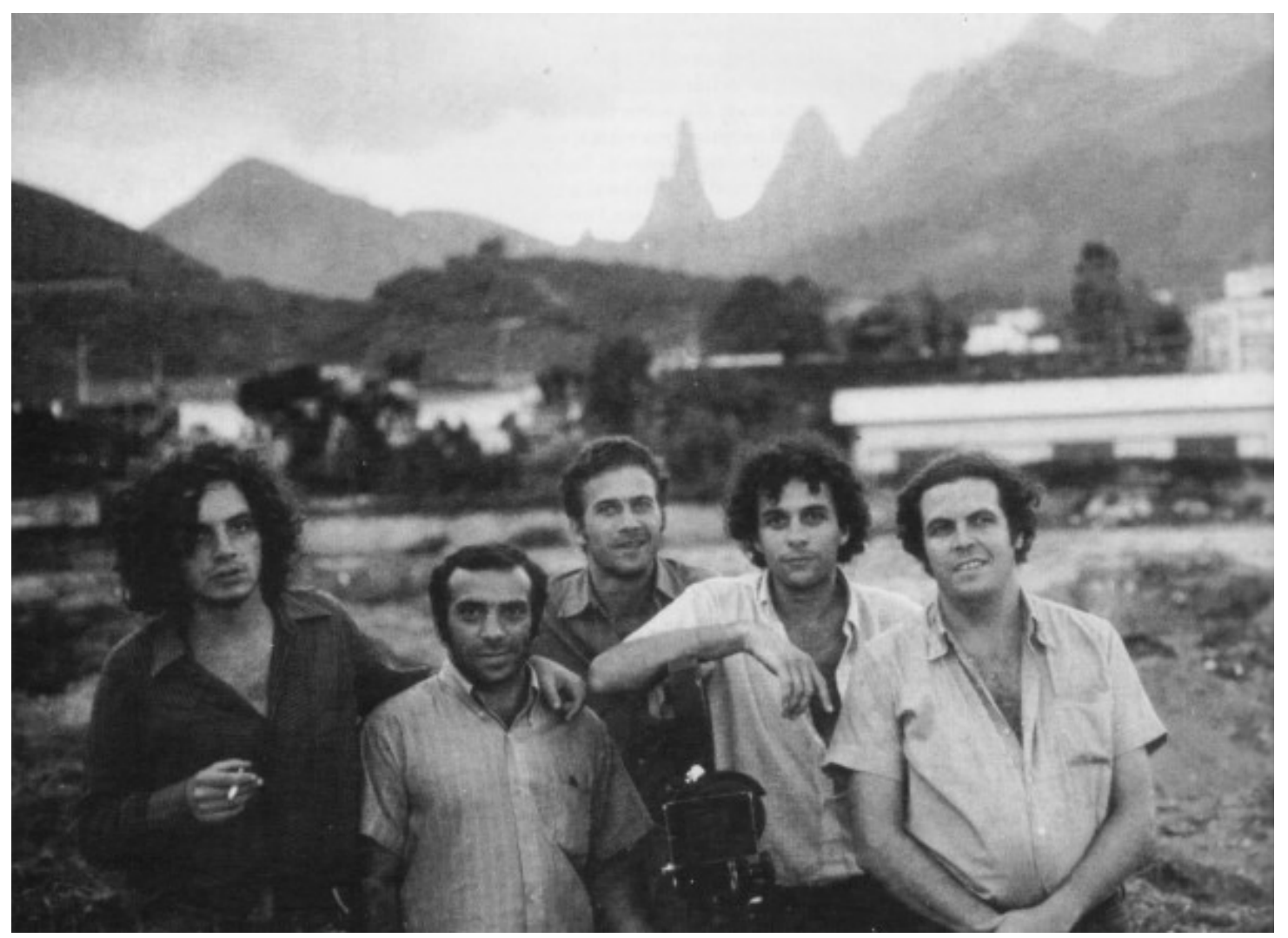

Fonte: http://luciointhesky.wordpress.com/2011/06/16/belair-a-nossa-atlantida-udigrudi/ Acesso em 23/12/2012

Elyseu Visconti, cineasta integrante do ciclo Marginal, amigo e colaborador da Belair, também montador do filme "Carnaval na lama" (1970), de Sganzerla, e diretor de arte de "Barão Olavo, o horrível" (1970), de Júlio Bressane, conta em entrevista para a Mostra Ocupação que os filmes da Belair eram de baixíssimo orçamento e feitos, algumas vezes, com um cartão de crédito. Era um esquema de produção hábil e com fervor. Comenta que o filme "Barão Olavo, o horrível" foi feito em um dia na casa dele (VISCONTI, 2010). 
Os dois primeiros longas de Sganzerla, "O Bandido da Luz Vermelha" e "A Mulher de Todos," alcançaram certo sucesso de público e tiveram um bom retorno financeiro, ambos com produção final e distribuição asseguradas por produtores da Boca do Lixo. Os três filmes seguintes realizados na Belair radicalizavam alguns elementos estéticos inclusos nos dois primeiros longas e ressaltavam a ruptura com possíveis expectativas de aceitação por parte do público espectador. Estes filmes trazem em sua narrativa um completo desprendimento em relação ao mercado exibidor (RAMOS, 1987).

\begin{abstract}
Os filmes da Belair apresentam os traços mais radicais do grupo marginal em termos de um questionamento da narrativa cinematográfica e do próprio ato através do qual a representação cinematográfica se constitui. São filmes que mantêm entre si uma impressionante coesão estilística. O mundo ficcional se apresenta fragmentado e 0 tom da representação constantemente se eleva para atingir graus extremos de intensidade dramática. A ação parece ter uma direção única em seu movimento: no sentido da repetição, da fragmentação e da elevação do tom dramático (RAMOS, 1987, p.96 e 97).
\end{abstract}

Os filmes de Sganzerla seriam representações da periferia do capitalismo, mergulhada na miséria, na exploração e na criminalidade, vista por uma ótica violenta e sem pudor.

Os cineastas marginais pareciam ter uma visão sarcástica do mundo e suas obras como um espelho de imensa gozação. A postura do "avacalho" que a maioria teve em relação ao cinema "sério", de arte, pretendido pelo Cinema Novo, era chamada de "curtição". Rogério Sganzerla declara no artigo intitulado "A Mulher de todos", publicado no Jornal do Brasil, em 20 de fevereiro de 1970, estar "buscando aquilo que o povo brasileiro espera de nós desde a Chanchada: fazer do cinema brasileiro o pior do mundo" (RAMOS, 1987, p.41).

A obviedade pode ser encontrada no estilo de Rogério Sganzerla, um procedimento narrativo de grande alcance estético. O cineasta comenta sobre seu segundo longa metragem "A Mulher de Todos", na Revista Artes, em 1970: "em A Mulher de Todos sou voluntariamente acadêmico porque só assim estarei fazendo cinema de invenção. (...) Isto é A Mulher de Todos, filme das panorâmicas didáticas, das situações óbvias, dos movimentos corretos e eloquentes. O estilo é supernormal para melhor afirmar sua anormalidade" (RAMOS, 1987, p.73).

Nos filmes seguintes realizados por Sganzerla na produtora Belair, a fragmentação narrativa e o dilaceramento existencial dos personagens começam a 
tomar contornos que avançam em progressão geométrica. O "avacalho" e a "curtição" possuem um sentido mais direcionado para a manutenção de uma postura de agressão em relação ao público. Essa característica se acentua nos filmes do cineasta e durante o seu exílio em Londres.

Alguns atores estavam totalmente afinados com o espírito da estética marginal e integrados com o grupo, dentre eles, pode-se citar alguns presentes na filmografia de Sganzerla: Helena Ignez, Maria Gladys e Paulo Villaça.

Helena Ignez é uma das personalidades mais representativas da história do cinema brasileiro na década de 60. A essência marginal personifica na figura da atriz, que é debochada, irreverente, degradante. Nos filmes de Rogério Sganzerla, interpretou a prostituta traidora Janete Jane, em "O Bandido da Luz Vermelha"; a mulher atraída por "boçais" Angela Carne e Osso, em "A Mulher de Todos"; e a exacerbada aos vômitos, em "Sem essa Aranha". Atuou também em filmes dos cineastas marginais Júlio Bressane e Elyseu Visconti. A atriz aprende com precisão a constituição que os diretores tentam dar aos personagens que representa.

Outra atriz que simbolizou o pensamento marginal foi Maria Gladys. Com seu físico magro e seu jeito irreverente e avacalhado, acabou criando uma imagem própria, explorada pelos cineastas marginais. Atuou em filmes de destaque do Cinema Marginal, tais como "O Anjo Nasceu", de Júlio Bressane, e "Sem essa Aranha", de Rogério Sganzerla (figura 13). Tem um estilo próprio de interpretar e representar os personagens, a marca da exasperação e dos estados de espírito extremos, características do ciclo Marginal.

Figura 13 - Gladys em cena do filme "Sem essa Aranha", de Rogério Sganzerla, 1970.

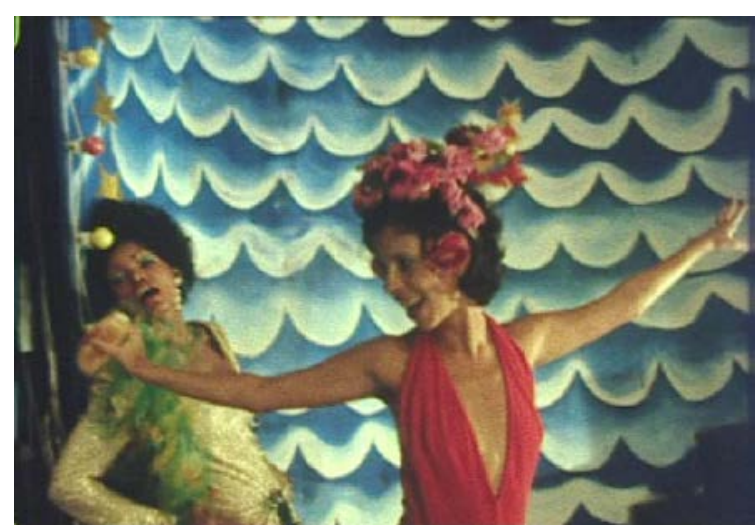

Fotograma do filme. 
Paulo Villaça começa com sua interpretação absoluta em "O Bandido da Luz Vermelha", onde consegue captar o lado mais "boçal" dos personagens marginais e exprime a indiferença existencial do personagem central. Ele representa de maneira forte a inquietação dos personagens que encena e tem uma capacidade singular de expressar nos berros e na sua expressão facial a dimensão do horror. O ator interpretou outros personagens em filmes de Rogério Sganzerla como em "A Mulher de Todos" e "Copacabana Mon Amour". Também trabalhou com os diretores Neville D’ Almeilda, Geraldo Veloso, Júlio Bressane e Elyseu Visconti.

\subsection{Rogério Sganzerla: vida e obra}

Rogério Sganzerla nasce em Joaçaba, Santa Catarina, em 4 de maio de 1946. No início dos anos 60, muda-se para São Paulo e passa a frequentar as sessões da Cinemateca Brasileira e cineclubes, interessando-se pela obra de cineasta americano Orson Welles ${ }^{4}$.

Assim como os grandes críticos do cinema moderno, o fato de comparecer aos cineclubes para rever os filmes e, assim, obter uma maior percepção fílmica, direcionou Rogério Sganzerla a realizar uma produção crítica publicada nos maiores jornais do país, antes mesmo de completar vinte anos (CANUTO, 2006).

Entre 1964 e 1967, jornalista e crítico de cinema escreve para o Suplemento Literário do jornal O Estado de S. Paulo. O arsenal criativo e o referencial crítico de Sganzerla foram fundamentais para realizar uma obra-prima em seu primeiro longametragem como diretor "O Bandido da Luz Vermelha", em 1968, quando tinha um pouco mais de vinte anos.

Antes disto, Rogério tinha estreado na direção com o curta "Documentário", em 1967. O filme narra as conversas e andanças de dois jovens que procuram uma sessão de cinema em São Paulo para passar o tempo. Apesar do nome do filme ser "Documentário", é, aparentemente, uma ficção.

Rogério Sganzerla começou sua carreira quando o Cinema Novo estava vigente. Qualquer atitude cinematográfica no Brasil não poderia ignorar o Cinema Novo, que já ultrapassava os limites cinematográficos e se tornava um acontecimento da cultura culta do Brasil. Pois foi no seio do Cinema Novo que

${ }^{4}$ Orson Welles (1915-1985) cineasta americano estreou no cinema com o filme "Cidadão Kane" (1941), considerado pela crítica um dos melhores filmes de todos os tempos, com estética inovadora. 
Sganzerla se formou. O cineasta escreveu artigos elogiosos no Jornal O Estado de São Paulo sobre os cinemanovistas Glauber Rocha, Paulo César Saraceni e Ruy Guerra.

Outras heranças estão presentes na obra de Rogério Sganzerla, entre elas a Chanchada, os cineastas Mário Peixoto ${ }^{5}$ e Orson Welles, o filme americano "B", os escritores Lima Barreto e Machado de Assis, a canção popular dos anos 30, e a própria linguagem cinematográfica da Nouvelle Vague e dos experimentais americanos (BERNADET, 1990).

O universo neobarroco, antropofagicamente repleto de referências, já fazia parte das críticas do autor, e são nítidas no filme "O Bandido da Luz Vermelha". Em cada enquadramento, é possível realizar uma leitura longa dos objetos de cena (vide figura 14), da riqueza de informações contidas em cada diálogo, em cada plano sequência, e na montagem. No filme, tudo é propositalmente exagerado, inclusive os figurinos e as interpretações.

Figura 14 - O Bandido experimenta vários óculos em sequência do "Bandido da Luz Vermelha", 1968, onde se observa diversos objetos de cena sobre a mesa.

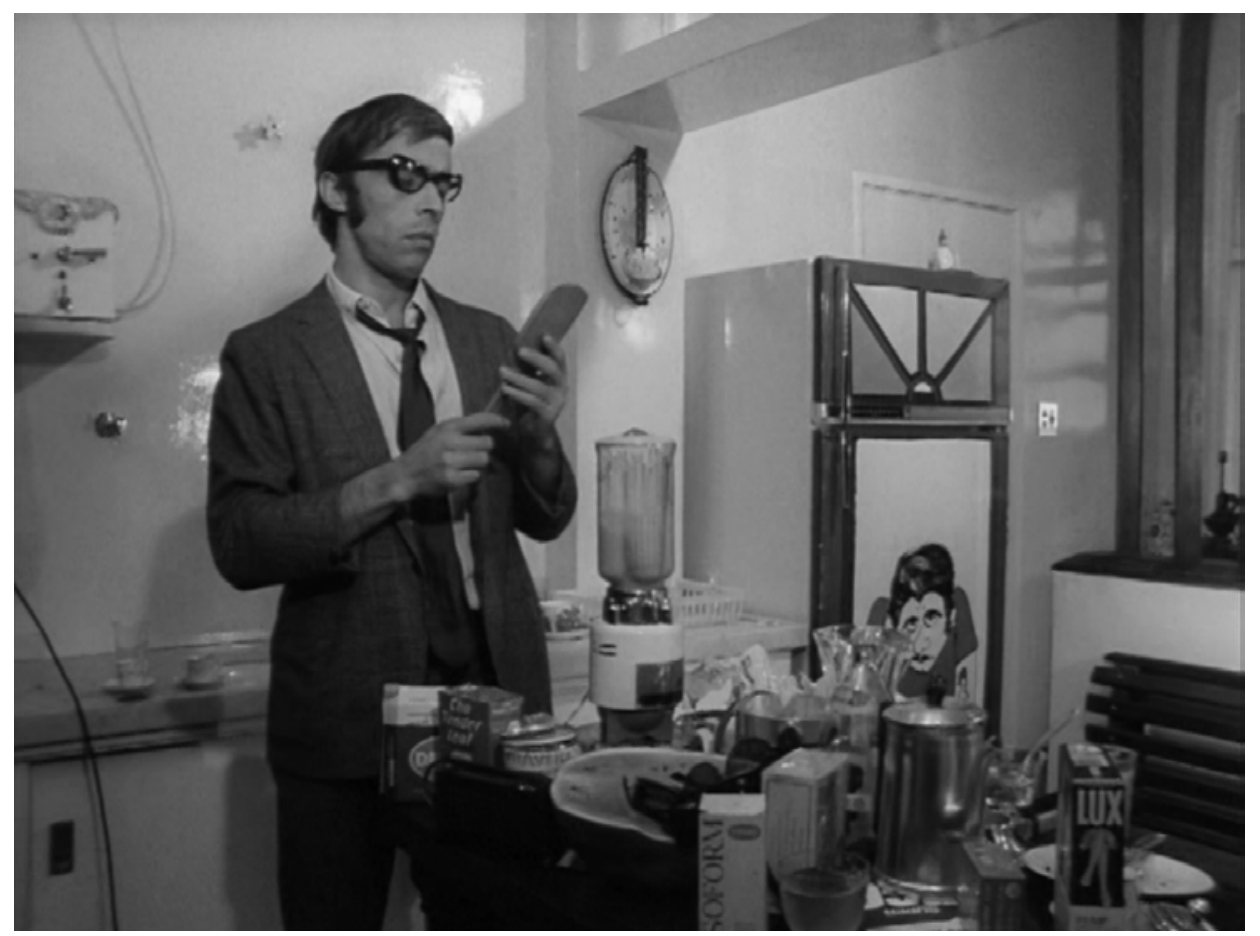

Fotograma do filme.

\footnotetext{
${ }^{5}$ Mario Peixoto (1908-1992): Cineasta, roteirista e escritor brasileiro, reconhecido pelo filme "O Limite" (1931), considerado um dos clássicos mais importantes do cinema brasileiro.
} 
A cultura pop jamais escapou do repertório de Rogério Sganzerla, um cinema que pretendia ser acessível, sem renunciar à atualidade artística, popular e transformadora ao mesmo tempo. A obra de Sganzerla está diretamente relacionada ao universo das histórias em quadrinhos, que caracteriza a narrativa marginal constituída de um mundo ficcional marcadamente fantasista. O interesse e a proximidade de Sganzerla pelo mundo dos gibis estiveram presentes durante sua vida, inclusive em 1969, realizou dois curtas-metragens intitulados "História em Quadrinho" e "Quadrinhos do Brasil".

No cinema moderno aglutinam-se neobarroco, kitsch e Pop Art; documento com aventura, arte com entretenimento, humor com reflexão (SGANZERLA, 2001)

Em 1969, filma o longa "A Mulher de Todos", onde Helena Ignez protagoniza a personagem Angela Carne e Osso, mulher emancipada e adepta do nudismo, mas que, a exemplo do "Bandido", não sabe quem é. O cenário é o mundo da alta sociedade paulista em trânsito com o crime, as drogas, o sexo. Este filme foi sua maior bilheteria.

No início dos anos 70, após o sucesso dos dois longas, "O Bandido da Luz Vermelha" e "A Mulher de Todos", Rogério segue para o Rio de Janeiro, onde cria com Júlio Bressane a produtora Belair, como cita Flávio Reis:

\footnotetext{
Depois do impacto causado e do sucesso dos dois filmes, Sganzerla vai para o Rio de Janeiro e junto com Júlio Bressane, Helena Ignez e um pessoal da pesada, incluindo atores e equipe técnica, fazem acontecer o sonho fulgurante da Belair, uma produtora visando a elaboração de trabalhos a custo baixo, em regime de muita liberdade criativa, movidos apenas pela necessidade premente de filmar - na contracorrente das preocupações então cada vez maiores com a viabilização de esquemas industriais (REIS, 2005, p.62 e 63).
}

Na Belair, em 1970, filmou e produziu "Copacabana Mon Amour" (com trilha original de Gilberto Gil), "Sem essa Aranha", "Carnaval na Lama", além de "Betty Bomba, a exibicionista", rodado parte em Nova Iorque. Este último é um filme desaparecido, a única cópia existente extraviou-se em 1992 e os negativos estão parcialmente destruídos. Segundo Reis, para Sganzerla, a experiência da Belair significou uma mudança em sua forma múltipla de narrativa, passando do impreciso dos primeiros filmes para o mais abertamente indefinido (REIS, 2005). 
Os filmes produzidos na Belair eram de baixo custo, realizados em um esquema ágil de produção a partir dos negativos acumulados. Segundo Rogério Sganzerla, o nome "Belair" surgiu a partir da marca de um carro conversível da década de 50, indicativo da atração do grupo pelo objeto kitsch (RAMOS, 1987).

Muitas vezes os personagens de Rogério Sganzerla eram criados a partir do discurso de outro autor. Era feito uma reelaboração da matriz, deixando claro a procedência. O original sofria uma acentuação de seus traços mais marcantes, criando um universo ficcional extremamente estilizado.

O personagem tipificado torna-se espesso pelos procedimentos de estilização citados acima. É o caso do personagem Aranha, interpretado por Jorge Loredo (figura 15) em "Sem essa Aranha", filme considerado uma chanchada psicodélica. Suas ações e seus movimentos corporais são extremamente rebuscados e acentuados, sendo que fala muitas vezes em rimas, com frases desconexas. A figura com conotações de gosto duvidoso, com um discurso de latin lover, é significativa no procedimento de caracterização excessiva de atitudes próprias da narrativa marginal (RAMOS, 1987).

Figura 15 - Jorge Loredo no filme "Sem essa Aranha", de Rogério Sganzerla, 1970.

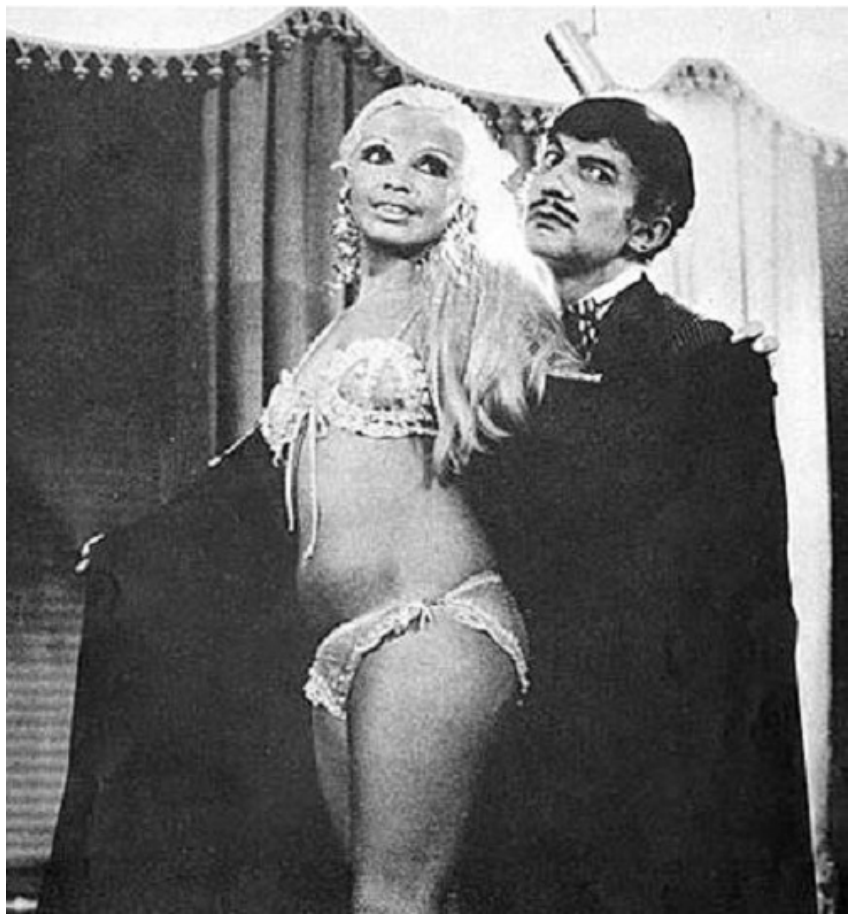

Fonte: $\frac{\text { http://luciointhesky.wordpress.com/2011/06/16/ }}{\text { Acesso }}$ Acesso em 23/12/2012 
O personagem de Jorge Loredo, caricatura representativa, figura em dois ou três filmes do ciclo Marginal. A associação entre Sganzerla e o ator Jorge Loredo tem grande relevância para o cinema brasileiro.

No filme "Sem essa Aranha" não existe mais preocupação com ordenamento narrativo: é um mergulho da câmera na atuação livre dos atores, palavreado desesperado, gritos e vozes fora da cena; a câmera na mão, em constante movimento, monta a cena. Sganzerla apresenta o subdesenvolvimento na cidade do Rio de Janeiro com escarnecimento. Para as lentes do cineasta, não havia nada mais evidente e urgente na paisagem carioca que a exuberância da favela (REIS, 2005).

O cinema de Rogério Sganzerla é de personagens fortes, colocados sob excesso de informações, suposições e classificações, cujo efeito é produzir uma descaracterização geral, ou estabelecer uma situação de impossibilidade das definições. É definido um processo de decomposição dos personagens, ao mesmo tempo, por sonegação e excesso de informações.

Três dos personagens principais do autor, o Bandido ("O Bandido da Luz Vermelha"), Angela Carne e Osso ("A Mulher de Todos") e Aranha ("Sem essa Aranha") possuem uma crise de identidade acompanhada da percepção da inutilidade das ações (REIS, 2005).

Vale destacar os personagens mais icônicos da obra do autor:

- Bandido da Luz Vermelha: Interpretado pelo ator Paulo Villaça (figura 16), talvez seja o personagem mais conhecido da obra de Rogério Sganzerla. Ele é o anti-herói. Segundo o próprio diretor, tinha uma voz grave e a face de um Humphrey Bogart "acaboclado", além de lembrar o verdadeiro Bandido da Luz Vermelha. Segundo Ebert, Villaça possuía o phisique du rôle adequado para desempenhar o Bandido (EBERT, 2013).

- Angela Carne e Osso: A atriz Helena Ignez a interpreta no filme "A Mulher de Todos". É uma das personagens preferidas pela atriz, conforme declarou em entrevista dada para esta pesquisa em julho 2015. É anárquica, mas ao mesmo tempo é uma mulher como toda brasileira. A personagem fuma charuto, como se pode observar na figura 17. A estratégia cênica consistiu no uso do charuto como objeto fálico, que dimensiona o apetite sexual desenfreado de Angela na ordem de sua virilidade (IGNEZ, 2015). 
Figura 16 - Paulo Villaça interpretando "O Bandido da Luz Vermelha”, 1968.

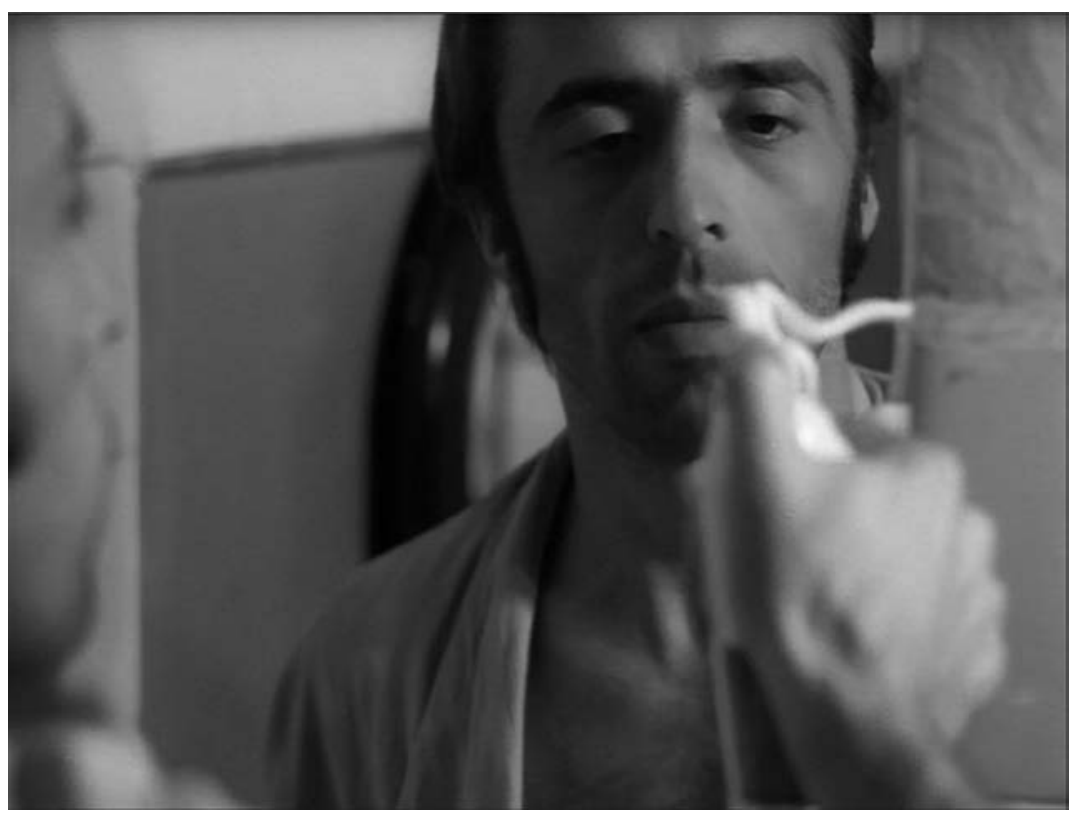

Fotograma do filme.

Figura 17 - Cena do filme "A Mulher de Todos" (1969).

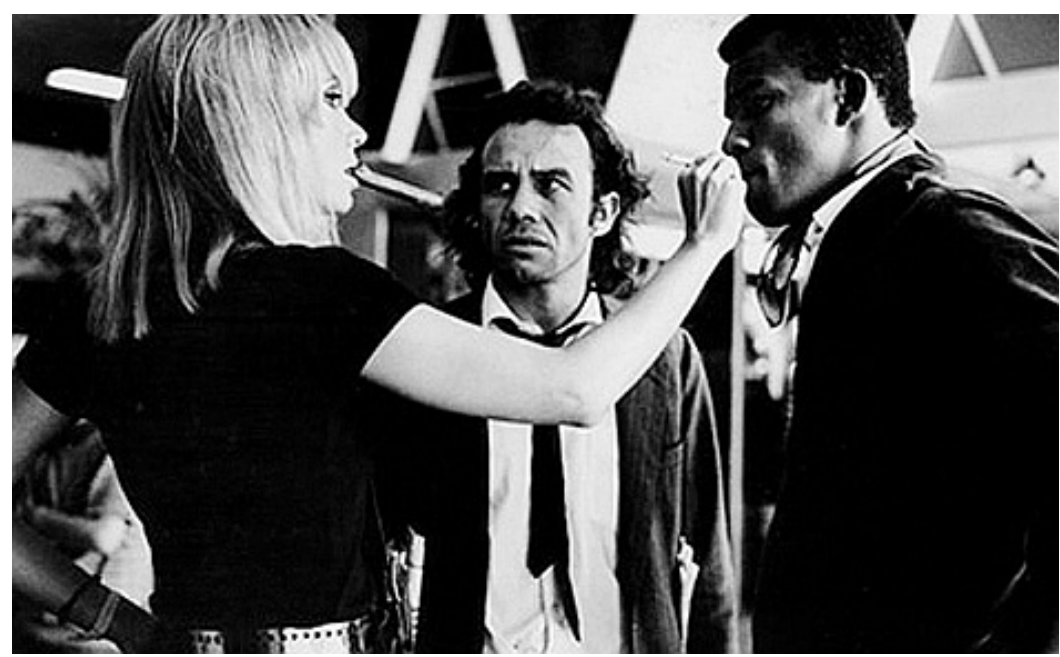

Fonte: http://revistacult.uol.com.br/home/2014/10/a-teoria-queer-e-os-desafios-as-molduras-do-olhar/ Acesso em 08/11/2015

- Aranha: o personagem interpretado por Jorge Loredo no longa-metragem "Sem essa Aranha" é o último capitalista do país, o latin lover.

- Sonia Silk: a mulher com cabelos oxigenados (figura 18) é outra personagem interpretada por Helena Ignez no filme "Copacabana, Mon Amour" (1970), também citada como preferida pela atriz em entrevista. Inclusive, no último longa-metragem dirigido por Helena Ignez, "Ralé" (2015), a autora faz um tributo à personagem (IGNEZ, 2015). 
Figura 18 - Sonia Silk (Helena Ignez) em cena do filme "Copacabana, Mon Amour" (1970), de Rogério Sganzerla.

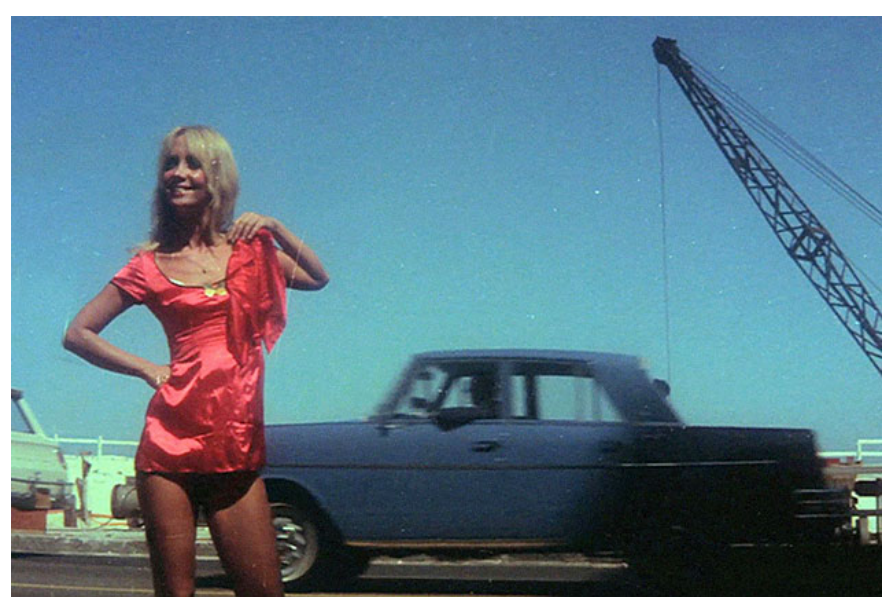

Fonte: http://www1.folha.uol.com.br/ilustrada/2015/01/1571776-mostra-de-sganzerla-resgatacopacabana-mon-amour.shtml

Acesso em 08/11/2015

- A personagem histérica interpretada pela atriz Maria Gladys no filme "Sem essa Aranha", enfatiza a característica da histeria no cinema Marginal. Ela grita praticamente o filme todo "Eu tô com fome, tô com fome!", (figura 19). No mesmo filme, num longo plano-sequência, canta a canção "Babalu", antigo sucesso de Angela Maria ${ }^{6}$, como foi apresentado anteriormente na figura 13.

Figura 19 - Maria Gladys em cena do filme "Sem essa Aranha" descendo a Ladeira do Vidigal, Rio de Janeiro, aos berros.

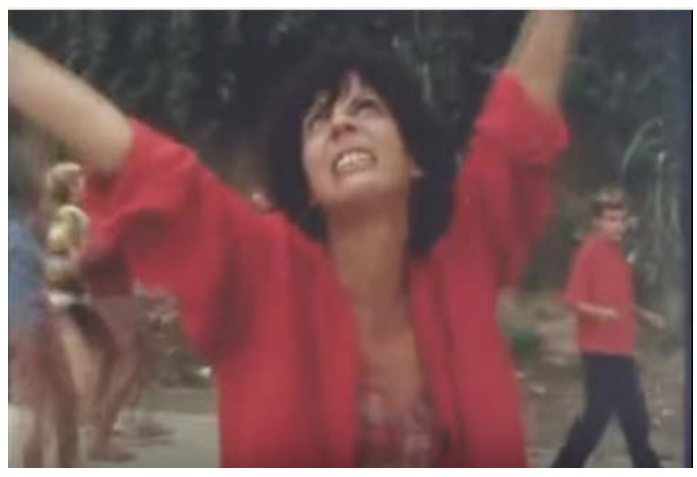

Fotograma do filme

- Doctor Plirtz: personagem hilário interpretado por Jô Soares no filme "A Mulher de Todos" (1969). Proprietário de empresas de histórias em 
quadrinhos é casado com a insaciável Angela, Carne e Osso (Helena Ignez). Um personagem reacionário, com postura nazista (Figura 20).

Figura 20 - Jô Soares como Doctor Plirtz em "A Mulher de Todos".

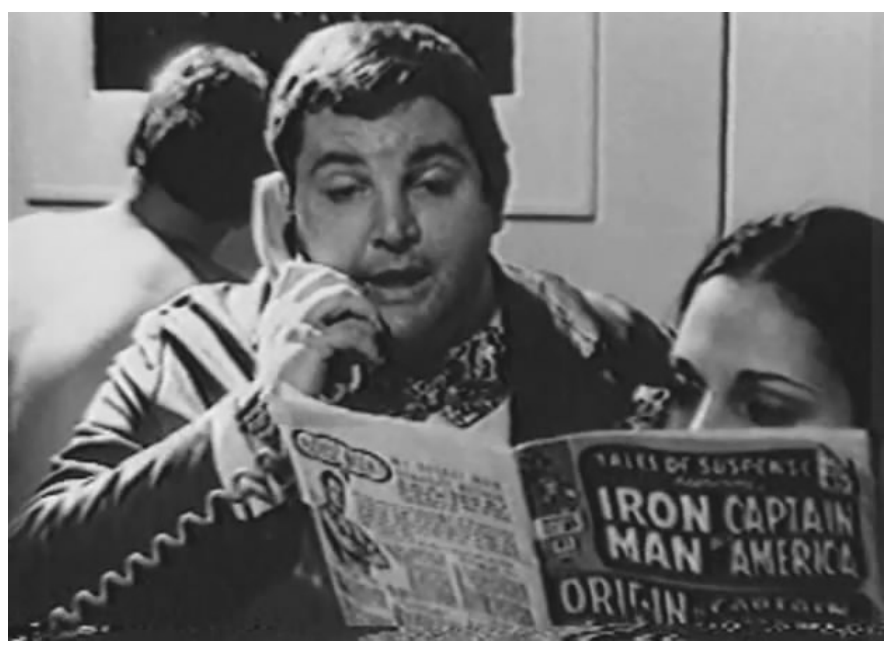

Fonte: http://dialeticadazueira.blogspot.com.br/2014/09/me-chama-de-bitolado.html Acesso em 09/11/2015

- Madame Zero: uma das personagens mais interessantes do cinema de Sganzerla, é interpretada por Norma Bengell no filme "Abismu" (1977). Uma mulher, considerada uma "diva vaporosa" fuma um enorme charuto, como pode ser visto na figura 21.

Figura 21 - Norma Bengell interpretando a personagem Madame Zero em "Abismu" (1977).

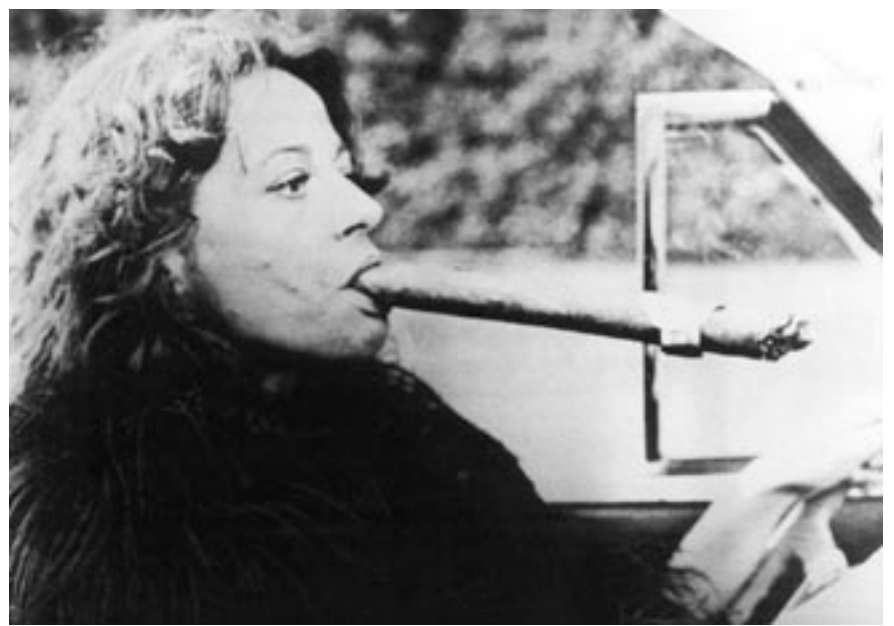

Fonte: http://www.contracampo.com.br/58/abismu.htm Acesso em 08/11/2015 
Com influência direta na cinematografia de Orson Welles, Jean-Luc Godard, Michelangelo Antonioni e Samuel Fuller, além de utilizar com frequência os clichês dos filmes noir ${ }^{7}$ e das pornochanchadas ${ }^{8}$, Sganzerla apresentou sempre um cinema de ruptura, inclusive com os próprios modelos.

Ao contrário da mistificação nacionalista da época, tampouco renega a cultura norte-americana: Jimi Hendrix seria outro exemplo. Mas, o tropicalismo, a paixão pela música nacional e Oswald de Andrade, também faziam parte do imaginário de Sganzerla. Para Ismail Xavier, o cineasta tinha uma adoração "tropicalista" pela Antropofagia (XAVIER, 1993).

\begin{abstract}
O deboche e a ironia como meios de contestação, a oposição aos ideais panfletários que a arte esquerdista assumia naquele momento, a busca de um Brasil para além dos discursos ufanistas, o diálogo com outras manifestações artísticas do planeta são alguns pontos de interseção entre a estética modernista e o cinema de Sganzerla. Mas, enquanto Oswald e Mário se interessavam primordialmente por uma investigação e afirmação da cultura brasileira, multifacetada e antropofagicamente rica, a geração de 1960 representava a estética antropofágica através de um filtro social e político essencialmente urbano (CANUTO, 2006, p.20).
\end{abstract}

Helena Ignez, musa do Cinema Marginal, foi casada com Rogério Sganzerla, mas antes disso foi a primeira esposa de Glauber Rocha, acompanhando desta maneira as crises e reviravoltas sofridas pelo cinema brasileiro. A atriz abandonou a facção do Cinema Novo e aderiu totalmente aos marginais, quando posou junto a Sganzerla, em 1970, na capa do jornal O Pasquim para a entrevista intitulada "Helena - A Mulher de Todos - e seu homem", onde ambos rompem com o Cinema Novo, como se observa abaixo na figura 22.

Em abril de 1970, Júlio Bressane foi obrigado a se retirar do país, pois o governo dizia haver evidências de que ele "fazia parte de uma ação de subversão na cultura, fomentada pelo terrorismo". Em menos de 24 horas, Júlio Bressane, Rogério Sganzerla e Helena Ignez partiram para Paris, de onde seguiram para o exílio em Londres (RAMOS, 1987, p.98).

\footnotetext{
${ }^{7}$ Filme noir: gênero cinematográfico muito comum no cinema norte-americano da década de 40 , influenciado pela literatura de ficção policial.

${ }^{8}$ Pornochanchada: gênero do cinema brasileiro onde existe uma mistura de comédias de costumes com erotismo leve e paródias ao cinema erótico europeu e americano.
} 
Figura 22 - Capa do jornal “O Pasquim”, número 33, em 1970.

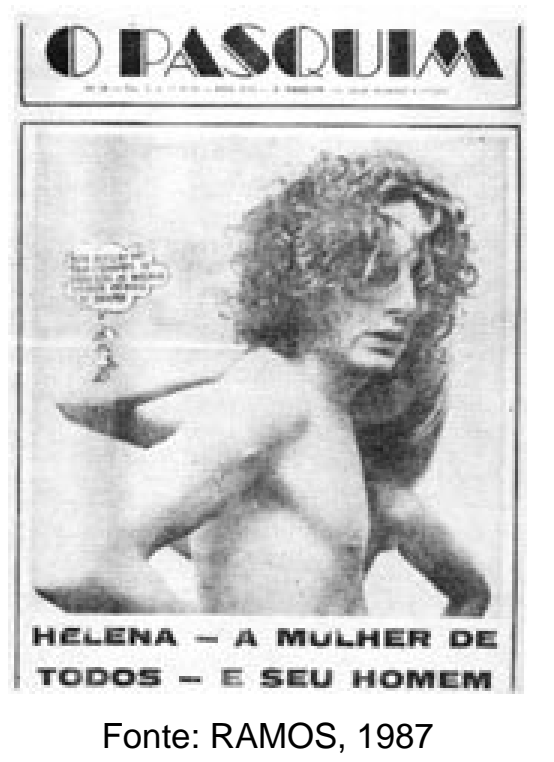

Segundo Elyseu Visconti, a época da ditadura era "uma panela de pressão", e os dois, Rogério Sganzerla e Júlio Bressane, tinham que sair do Brasil senão seriam presos (VISCONTI, 2010).

Júlio Calasso Junior, em entrevista para esta pesquisa, comentou que Júlio Bressane soube que seria preso, pois seu pai o General João Bressane obteve esta informação (CALASSO, 2015).

"Sem essa Aranha" foi o último filme da série carioca de Sganzerla junto a Belair. Como ele saiu do Brasil às pressas, levou as latas de negativo na mão, que foram reveladas em Paris no laboratório da "Éclair", empresa francesa integrada à indústria cinematográfica.

No período que Rogério Sganzerla esteve fora do país, filma o documentário "Fora do Baralho" (1972), que tem como cenário o Deserto do Saara, porém é um projeto inacabado com 54 minutos de imagens em material bruto. Volta ao Brasil em 1972, mas só retoma o cinema em 1976 com o curta-metragem "Viagem e descrição do Rio Guanabara por ocasião da França Antártica" e em seguida com o longametragem "Abismu" (1977).

A obra de Sganzerla despertou interesse não só da crítica cinematográfica, mas também literária. Os poetas concretos Haroldo e Augusto de Campos mergulharam no filme "O Bandido da Luz Vermelha", que dialogava com toda a vanguarda e revolucionava a arte daquele momento do Brasil. Augusto de Campos, no livro "O balanço da Bossa e outras bossas", apresenta uma radiografia do 
panorama artístico e cultural nas décadas de 1960 e 70, tendo como guia o viés musical. Ao falar de cinema, o autor identifica a obra de Rogério Sganzerla como a representação mais pura da experimentação, através de generosos elogios.

Roberta Canuto cita em sua dissertação de mestrado:

\begin{abstract}
Sganzerla fez do seu cinema um exercício de experimentação e discurso imagético, libertando a nossa cinematografia de um discurso literário, para transportá-la ao reino da liberdade poética. Rogério Sganzerla fazia "filmes de cinema", como ele ironizou nos letreiros iniciais de $O$ bandido, zombando dos velhos conceitos de "cinema de arte", que a intelectualidade teimava em cercear em correntes e escolas. Rogério Sganzerla soube pensar e fazer cinema como poucos, somando o potencial das palavras ao das imagens, para desenvolver um universo que, para ele, vivia em permanente invenção, e pelo qual ele trilhou sua vida. Em seus momentos finais, em um hospital, lutando contra o câncer, Sganzerla resumiu a força do cinema em sua vida, dizendo: 'Só uma câmera poderia me salvar (CANUTO, 2006, p.100).
\end{abstract}

O cineasta também dirigiu os curtas-metragens "Noel por Noel" (1981), "Brasil" (1981), "Perigo Negro" (1993), os longas-metragens "Nem tudo é verdade" (1986), "O signo do caos" (2003) o último longa de sua autoria, e os documentários "A linguagem de Orson Welles" (1991), "Tudo é Brasil" (1997). Também foi montador de filmes de outros cineastas marginais, como exemplos "Olho por Olho" (1966) de Andrea Tonacci e o curta "Bom Jesus da Lapa - o Salvador dos Humildes" (1970) de Elyseu Visconti.

Sganzerla é considerado ainda um excelente montador. Segundo Roberto Turigliatto, crítico cinematográfico italiano, Rogério Sganzerla foi um dos maiores montadores da história do cinema (TURIGLIATTO, 2010).

Morreu em 9 de janeiro de 2004, aos cinquenta e sete anos, no Hospital do Câncer, em São Paulo, vítima de câncer no cérebro, que sofria há cerca de seis meses. Deixou o roteiro do filme "Luz nas trevas, a volta do Bandido da Luz Vermelha", que foi lançado em 2010, e teve como diretora sua viúva Helena Ignez.

\title{
2.2. Aspectos sócio-político-culturais neste período
}

A virada da década de 1960 para 70 constitui um momento único para a linha histórica que conduziu a cultura mundial, ao longo do século XX. No mundo e no Brasil, o panorama político social e cultural representou o apogeu e apocalipse de um pensamento que moldou a sociedade ocidental moderna. Era o fim da inocência e o início de uma incendiária 'idade da loucura', com as portas abertas para um psicodelismo desenfreado, aliado a experiências em todos os campos. As experimentações artísticas geraram, nesse período, algumas das obras mais instigantes do cinema, literatura, 
teatro, música e artes plásticas; já no campo existencial, o experimentalismo ganhava contornos trágicos e divinos, ao mesmo tempo, provocando a morte de heróis míticos da contracultura e férteis viagens criativas sob o signo da liberdade (CANUTO, 2006, p.58).

O período do Cinema Marginal caracteriza-se como um momento de grande agitação em todo o mundo. Por volta de 1964, os EUA começaram a enviar seus soldados para a Guerra do Vietnã, ou "Guerra Americana" segundo os vietnamitas. O modelo imperialista americano não podia aceitar a influência socialista, e viceversa. Morreram mais de cinco milhões de pessoas entre vietnamitas, cambojanos e laocianos.

Malcom X, um dos grandes líderes dos negros norte-americanos, defensor do movimento de resistência chamado "Black Power" (Poder Negro, em inglês) nos Estados Unidos, foi morto em 1965. Ele defendia a separação das raças, a independência econômica e a criação de um Estado autônomo para os negros. Apesar do projeto não ter seguido, o líder obteve muita fama, viajando pelos Estados Unidos para pregar suas ideias e defender a libertação dos negros.

O ensino destinado aos bairros negros e latinos era muito fraco, então os habitantes destes bairros, por orgulho de lutar pelo seu país, formaram a maior parte dos batalhões de baixa patente, que não regressou. Seis meses depois da morte de Malcom X, assassinaram Martin Luther King, ativista político norte-americano que apostava em uma resistência pacífica como arma para enfrentar o racismo,

Algumas técnicas de propaganda e credibilidade, desenvolvidas durante a II Guerra Mundial (1939 - 1945), entram em cena. Durante a Guerra Fria, as potências União Soviética e EUA disparam corridas armamentistas e apoiam regimes militares pelo mundo. Aqueles que não queriam dar continuidade ao "milagre econômico" eram banidos, e muitas vezes se reagrupavam no exílio europeu.

A França não se atualizou para suprir as novas demandas e estudantes orientados por professores e intelectuais atuantes ocuparam a Faculdade de Nanterre e, em maio de 1968, invadiram a Universidade Sorbonne (figura 23). O Estado reagiu e, na noite das Barricadas, atacou. O resultado foi 400 feridos, entre estudantes e professores. A população ficou perplexa e, após 24 horas de greve nacional, as reivindicações se ampliaram. O movimento vazou para a rua (DAVID; SIMÕES; BORBA, 2012). 
No início da década, o Brasil buscava a superação do subdesenvolvimento, aspirando por mudanças sociais, enquanto suas indústrias passavam por um processo de reestruturação. A procura pela prosperidade e pela modernidade criava um clima de euforia.

Figura 23 - Louis Aragon, Daniel Cohn-Bendit, Alain Geismar em maio de 1968 na Place de La Sorbonne.

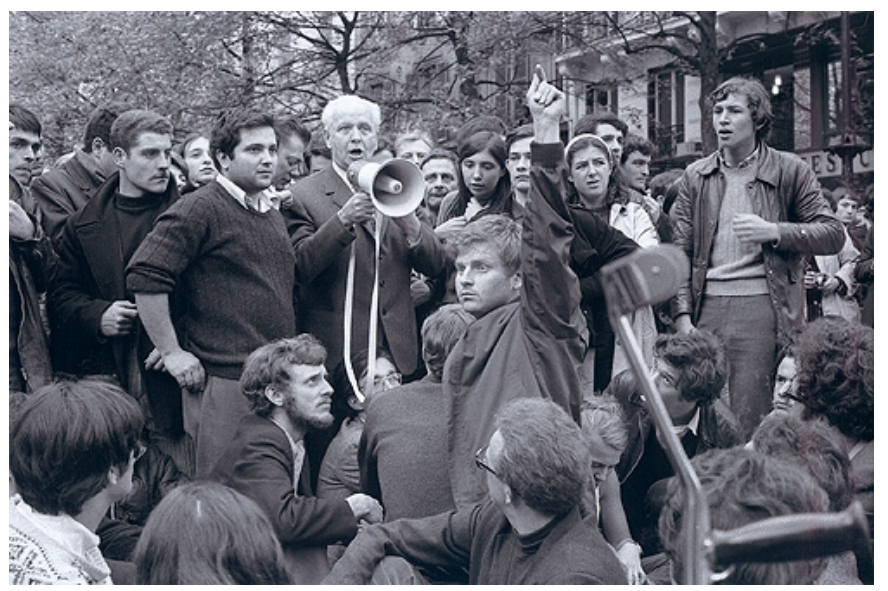

Fonte: http://findingnebulium.blogspot.com.br/2012/05/eike-blog-parado-parte-2.html

Acesso em 23/12/2012.

Mas, a partir de 1964, o Brasil vivia em plena ditadura militar - o Ato Institucional número 5 (Al-5), Médici ${ }^{9}$, e a tortura. Até 1968, o regime militar poderia ser pensado como algo transitório, mas com o decreto Al-5, baixado em 13 de dezembro de 1968, a situação se agravou e parecia não haver saída para a classe artística, para o cinema, onde existia uma moral se transformando.

Segundo Eugênio Puppo "Os filmes deste ciclo não caracterizam um estilo, nem uma corrente. Eles são, no entanto, um documento amplo sobre uma época e um estado de espírito" (PUPPO, 2001, p.27).

A cultura brasileira nos anos 50 e 60, marcada pela política, uniu-se às lutas que permeavam o todo social, e o cinema entrou numa disputa com a realidade, e assim, ocorreu um momento de superposição e estranhamento entre os processos estético-cultural e político-social (RAMOS, 1983).

No período de 1969-74 configura-se uma nova modalidade de ação estatal no interior do campo cinematográfico. É sob o signo do Al-5 e de uma nova

\footnotetext{
${ }^{9}$ Médici: Emílio Garrastazu Médici (1905-1985), presidente do Brasil durante o período mais crítico da Ditadura Militar.
} 
Constituição que se processa a tensa articulação entre as consequências da modernização, como o crescimento da indústria cultural, e uma rígida repressão e censura. Nesse momento, caracterizado como a segunda fase do Estado ditatorial, assiste-se às tentativas de redefinições para o setor cultural, numa clara preparação de terreno para uma política que só surgirá de forma articulada e explícita posteriormente (RAMOS, 1983, p.89).

Para a classe artística, o clima era repugnante, e talvez fosse desse choque que nascesse o cinema chamado "Underground", ou "Marginal", ou "de Invenção". Um cinema criado no meio desta confusão, não falava de beleza. Não ao acaso, em São Paulo, este cinema, se torna conhecido como Boca do Lixo, lugar onde as pessoas se reuniam e faziam filmes, na Rua do Triumpho e imediações, conhecida zona de prostituição.

A virada da década de 60 coincide com o fechamento político do regime militar, provocando a derrocada das ilusões reformistas dos anos 60, defendida por grande parte dos intelectuais brasileiros e com a qual se identificavam os produtores de cinema. Com este desmoronamento e a incapacidade ou impossibilidade de uma ação política, surge um clima de tensão, onde predomina o terror e a paranoia. A tortura física nesta época extravasa o gueto do submundo e passa a atingir os filhos excluídos de uma classe média desiludida. E é neste clima, onde delírio e realidade se misturam, que o terror passa a ser o cenário.

Dentro da ideologia da "contracultura", característica do início dos anos 70 ,
a conjuntura política particular do Brasil parece ter acrescentado um novo
fator, condizente com nossa realidade: o terror. Todo o discurso em torno da
experimentação do prazer se choca com o universo de repressão à
individualidade extremamente brutal. (...) Alguns cineastas do grupo
analisado chegaram a ser presos, muitos foram seguidos, tiveram suas
casas revistadas, foram intimados a prestar depoimentos, etc. E, ao fundo,
dando o tom a este ambiente um tanto paranoico e que permite dimensionar
muito do que vemos expresso na tela quando analisamos os filmes
marginais, a perspectiva da tortura e o dilaceramento corporal (RAMOS,
1987, p.36).

A frase "O que está errado é o que está certo e o certo é o que está errado" foi usada em filmes emblemáticos do ciclo Marginal no cinema brasileiro. Essa sentença soa como um sofismo nonsense, mas resume o espírito daquela geração, que, através de um discurso cada vez mais indireto, começava a escapar da violência e da censura, instigadas com a promulgação do Al-5.

O ano de 1968, quando o filme "O Bandido da Luz Vermelha" foi lançado, marcou o endurecimento da ditadura militar brasileira, passando de um regime de direita para um de extrema direita. 
A imposição do Al-5, o golpe dentro do golpe, estabeleceu uma relação muito clara entre o teor agressivo do cinema experimental, realizado a partir de 1969, e o fechamento definitivo do regime. Nas produções rotuladas de Cinema Marginal, observa-se o tom apocalíptico dos discursos, a referência à repressão, à violência e à tortura.

A situação presente no Brasil no início dos anos 70 força boa parte dos cineastas marginais a emigrar em direção à Europa. Estiveram no exterior, nem sempre na mesma época ou região geográfica escolhida para o exílio: Júlio Bressane, Rogério Sganzerla, Neville D'Almeida, Andrea Tonacci, Sylvio Lanna, Elyzeu Visconti, Geraldo Veloso, Luiz Rosemberg e outros.

Para Inácio Araújo, os filmes do Cinema Marginal mostravam agonia e dor. O cinema não era visto como uma arte; o bem-feito, a gramática coerente e a luz bem composta não tinham importância. O cinema era uma guerrilha contra o bom gosto e contra o mundo estabelecido, não representava o mundo preexistente. Existia um gosto pelo fantástico, pelos óvnis, pela ficção científica, pelos beatniks (PUPPO, 2001).

A famosa frase pronunciada no filme "O Bandido da Luz Vermelha", de Rogério Sganzerla (1968), "Quando a gente não pode fazer nada, a gente avacalha e se esculhamba", mostra a dimensão das transformações sofridas pela ideologia estabelecida ao redor da necessária inserção da obra no social durante o transcorrer da década de 60. Se não se pode fazer nada, o avacalho e o esculhambo não tem nenhum vínculo com atitudes construtivistas de ação.

Para o crítico norte-americano Robert Stam, num artigo publicado em 1979, intitulado "Brazilian Avant-Garde Cinema from Limit to Red Light Bandit", "o ponto alto do movimento underground, coincide com o amplo movimento cultural denominado Tropicalismo" (RAMOS, 1987, p.53).

Para alguns autores, a filiação do Cinema Marginal com o Tropicalismo deve ser traçada com reservas. Embora existam vínculos por razões de convivência temporal e espacial, a justaposição do arcaico e do moderno, a exposição fragmentária dos detritos industriais e das relíquias do Brasil, e a articulação destes elementos de uma forma alegórica, não podem ser consideradas como estruturas do Cinema Marginal, apesar de se fazer presente em alguns filmes do ciclo.

O Tropicalismo foi um movimento de ruptura que agitou o ambiente da música popular e da cultura brasileira entre 1967 e 1968. Os cantores-compositores 
Caetano Veloso e Gilberto Gil foram os artistas com maior destaque, além da cantora Gal Gosta, do compositor Tom Zé, da banda "Os Mutantes" e do maestro Rogério Duprat. Participaram também do movimento a cantora Nara Leão e os letristas José Carlos Capinan e Torquato Neto, e o artista gráfico, compositor e poeta Rogério Duarte (OLIVEIRA, 2000).

Os tropicalistas queriam universalizar a linguagem da MPB, agregando elementos da cultura jovem mundial, como o rock, a psicodelia e a guitarra elétrica. Eles uniam a eletricidade com as informações da vanguarda erudita por meio de arranjos diferenciados feitos por maestros. Ao unir o popular, o pop e o experimentalismo estético, as ideias tropicalistas acabaram incitando a modernização da música e da própria cultura nacional.

Algumas composições tropicalistas foram consideradas poesia, pois havia diálogo com obras literárias como as de Oswald de Andrade ou dos poetas concretistas. Suas canções formavam um quadro crítico e complexo do Brasil - uma conjunção do Brasil arcaico e suas tradições, do Brasil moderno e sua cultura de massa e até de um Brasil futurista, com astronautas e discos voadores.

A Tropicália inovou ao transformar os critérios do gosto vigentes, tanto em relação à música e à política, quanto à moral e ao comportamento, ao corpo, ao sexo e ao vestuário. A contracultura hippie foi assimilada, com a adoção da moda dos cabelos longos encaracolados e das roupas coloridas e irreverentes, como mostra a figura 24 .

Figura 24 - Os "Mutantes", Caetano Veloso e Gilberto Gil na estreia de "Divino Maravilhoso", na TV Tupi, em 28 de outubro de 1968.

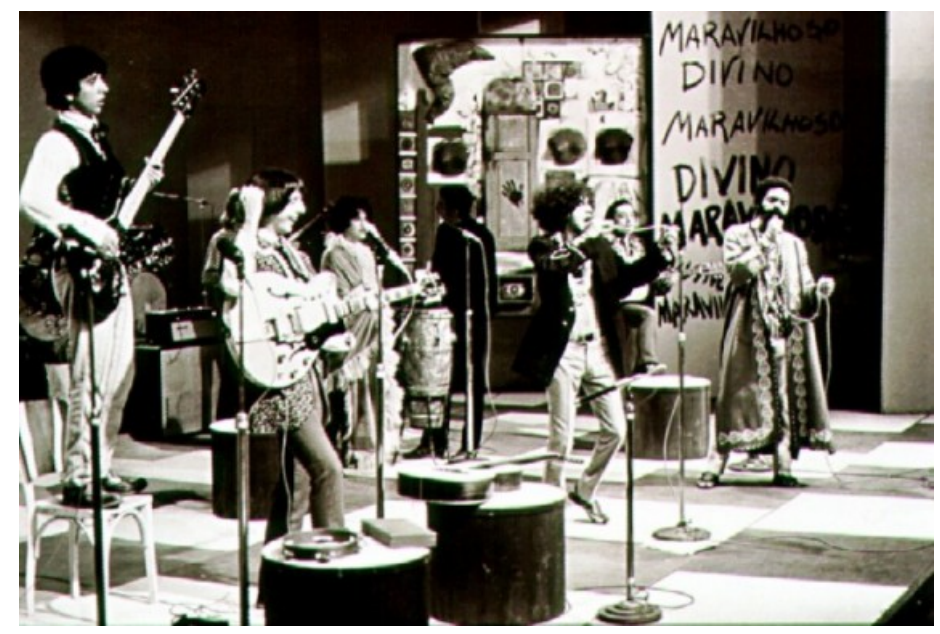

Fonte: http://tropicalia.com.br/olhar-colirico/fotos?page=3 Acesso em 01/01/2013 
O movimento foi reprimido pelo governo militar. O começo do seu fim teve início com a prisão de Gilberto Gil e Caetano Veloso, em dezembro de 1968, que depois seguiram para o exílio em Londres.

Nas artes plásticas, Hélio Oiticica e Lygia Clark fizeram da sua obra um completo exercício experimental de seu comportamento, somadas, num mesmo plano, elementos de várias vertentes vanguardistas daquele período. Através da obra destes artistas, conceitos fundamentais transitavam para a configuração do pensamento que moldou as décadas de 1960 e 70. Numa carta destinada à Lygia Clark em 1968, Oiticica escreve: "Para Marcuse (Herbert), os artistas são os que têm consciência e agem marginalmente, pois não possuem classe social definida" (CANUTO, 2006, p.63).

A Pop Art explodia na esfera mundial. Introduziu novos temas, eliminou as divisões entre as categorias como pintura, escultura, gravura e colagem e acrescentou aos meios e suportes tradicionais os diversos tipos de possibilidades oferecidas pela indústria e tecnologia, pelos canais de informação e pela comunicação de massa. Foi a partir das ideias de Marcel Duchamp ${ }^{10}$,quando as imagens do dia-a-dia e os objetos ordinários apresentados por artistas deixaram de ter o caráter utilitário e passaram a ser obra de arte, que se abriu o caminho para o deslocamento de elementos da cultura de massa para a área das artes.

Os artistas que protagonizaram o movimento dando uma fisionomia singular à arte de seu tempo foram: Robert Rauschenberg ${ }^{11}$, JasperJohns ${ }^{12}$, Andy Warhol ${ }^{13}$, Roy Lichtenstein ${ }^{14}$, Claes Oldenburg ${ }^{15}$, Tom Wesselmann ${ }^{16}$ e James Rosenquist ${ }^{17}$.

Os seguidores da Pop apontavam problemas sociais e se rebelavam contra o sistema da arte, desejando popularizar as obras de arte, que poderiam ser vendidas

\footnotetext{
${ }^{10}$ Marcel Duchamp (1887-1968): pintor e escultor francês, um dos grandes representantes do movimento Dadaísta.

${ }^{11}$ Robert Rauschenberg (1925-2008): artista norte-americano pertencente ao movimento expressionismo abstrato e posteriormente à Pop Art.

${ }_{12}$ Jasper Johns (1930): pintor norte-americano, um dos pioneiros na Pop Art.

${ }^{13}$ Andy Warhol(1928-1987): artista multimídia americano, maior representante da Pop Art.

${ }^{14}$ Roy Lichtenstein (1923-1997): Pintor estadunidense pertencente à Pop Art, com grande interesse por histórias em quadrinhos.

${ }^{15}$ Claes Oldenburg (1929): escultor norte-americano, de origem sueca, faz parte do grupo de artistas da Pop Art.

16 Tom Wesselmann (1931-2004): pintor norte-americano iniciou carreira fazendo histórias em quadrinhos e depois foi um dos integrantes da Pop Art.

${ }_{17}$ James Rosenquist (1933): pintor norte-americano, pertencente ao movimento Pop Art, reconhecido pela justaposição de imagens em grandes painéis.
} 
em supermercados, ou distribuídas em jornais e periódicos (CINTRÃO; SANT'ANNA, 2003).

No campo da moda internacional, as transformações já não estavam sendo ditadas de cima para baixo, como sempre havia sido na história do mundo ocidental. Na década de 60, elas vinham das ruas.

\begin{abstract}
No plano da arte, através das pesquisas experimentais de vanguarda, Giovanni Lista comenta "assiste-se a uma descompartimentização das artes e a uma coletivização do ato de criação, o que permite uma circulação e uma sinergia que são a origem de uma nova afirmação do lugar da arte na sociedade moderna". Tal sinergia - que se dá através da junção de várias linguagens, permitindo uma visão mais ampla do objeto, começa a ser experimentada com os happenings e desemboca nas performances. No Brasil, assim como no exterior, essa questão também é sentida nos diversos campos da arte: nas Artes plásticas, as experiências de Hélio Oiticica; no teatro tem-se o exemplo dos espetáculos do Arena - Arena canta Zumbi e Arena canta Bahia, entre outros. Mesmo os músicos percebem que seu novo tipo de música não pode ser expresso apenas pela voz e som dos instrumentos, Os Mutantes, Caetano Veloso e Gilberto Gil, introduzem em seus shows o impacto visual e as performances no palco (TOLEDO, 2004, p.21).
\end{abstract}

Em primeiro lugar nos Estados Unidos, mas no Brasil também e em todo o mundo, a geração do baby-boom ficou marcada na história por ser aquela nascida no pós-guerra e que cresceu num momento de grande prosperidade, educada para viver num âmbito com ausência de conflitos e traumas, e com muita liberdade.

Foi justamente esta geração, no auge de sua juventude, que tinha o discurso e procurava abrir os caminhos na década de 60. As garotas começaram a usar a pílula anticoncepcional, adotavam o amor livre, fumavam, moravam sozinhas e queriam se igualar ao homem, no sentido, que o homem era um ser igual a elas. Estas atitudes fundamentavam, filosoficamente, o feminismo.

Nota-se que durante as filmagens do filme "A verdade" (1960), do diretor Henri-Georges Clouzot, Brigitte Bardot posa para fotógrafos e jornalistas vestindo uma calça jeans e um suéter em tricot, como mostra a figura 25. Nesta foto, pode-se observar a nova postura da mulher da década de 60. Além de estar fumando, a atriz está sentada com as pernas abertas, movimento permitido pelo conforto das calças compridas.

A repulsa aos tabus sexuais é demonstrada pela renúncia ao soutien, considerado como o corselet usado até o início do século XX. Outra demonstração 
seria o fato das mulheres usarem roupas transparentes, exemplificada na cena do filme "A Mulher de Todos", de Rogério Sganzerla na figura 26.

O primeiro Festival de Woodstock, em 1969, foi o maior exemplo de desobediência civil da época. Meio milhão de jovens desertores assistiram aos três dias de shows históricos tomando LSD e fazendo sexo livre em decorrência da pílula anticoncepcional. Jimi Hendrix, Santanna, Janis Joplin, Joe Cocker, Ravi Shankar e Jefferson Airplane são alguns dos nomes que se consagraram (DAVID; SIMÕES; BORBA, 2012, p.23).

Figura 25 - Brigitte Bardot no set de filmagem do filme "A verdade", de HenriGeorges Clouzot, 1960.

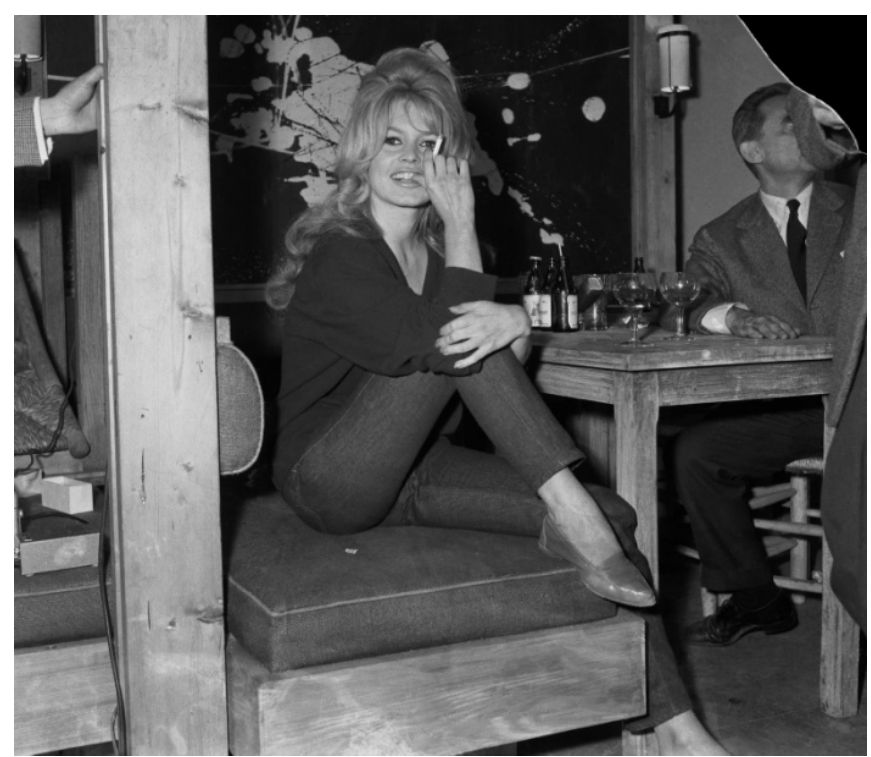

Fonte: http://brigittebardot.canalblog.com/archives/2010/07/04/18497569.html Acesso em 17/12/2012

Figura 26 - Helena Ignez na cena do filme "A Mulher de Todos”, 1969.

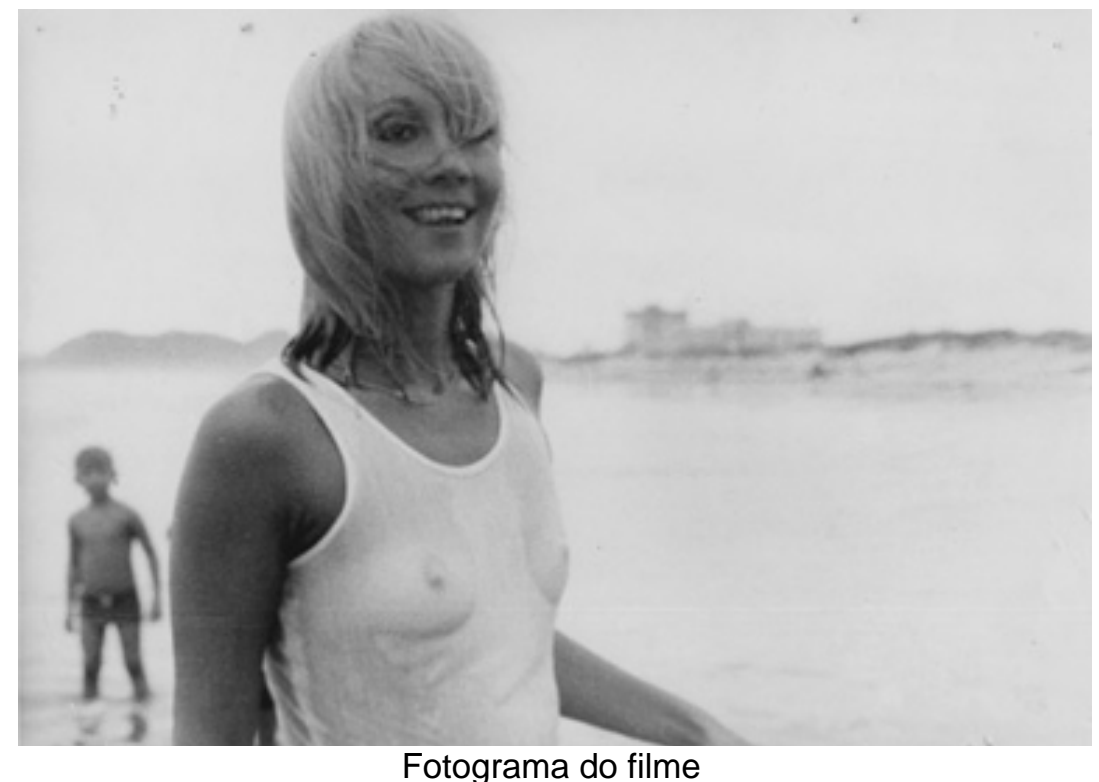

Fotograma do filme 
Jimi Hendrix ${ }^{18}$ foi um dos artistas que tocou no Festival de Woodstock, ao norte de Nova York, em 1969, como mostra a figura 27. Rogério Sganzerla era fã do músico, inclusive, escreveu artigos sobre o mito para a Folha de São Paulo, em 1980, intitulados "Retiro Espiritual" e "Jimi, gênio total", e fez o documentário sobre o músico "Mudança de Hendrix" (1970-1978).

A tríade "sexo, drogas e rock'n roll" não foi apenas um mito eternizado por ídolos da cultura pop, mas sim um horizonte cultural brasileiro e mundial estabelecido. Este triângulo ditava o comportamento, o pensamento e a estética daquele período. A revolução sexual, as experiências com drogas e a busca da consciência cósmica oriental faziam cenário para a criação artística e do pensamento intelectual daquela geração.

Figura 27 - Jimi Hendrix no Festival de Woodstock, em 1969.

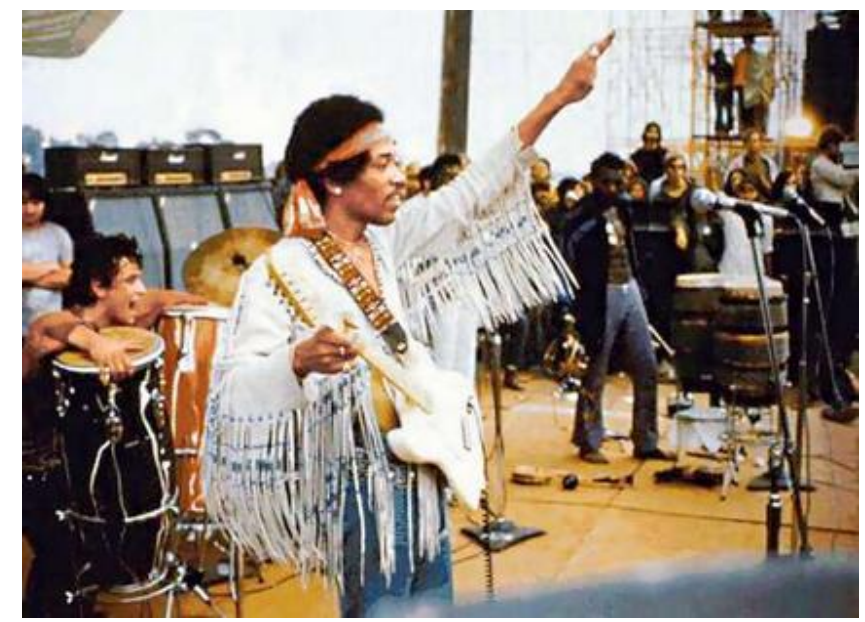

Fonte: http://www.mundomax.com.br/blog/tag/woodstock-fotos/ Acesso em 23/12/2012

Os jovens não aceitavam mais as roupas tradicionais, como o terno ou o tailleur. A rebeldia da juventude era explícita nos modos de se vestir ou pentear. Essa força era introduzida cada vez mais como um segmento quantitativamente expressivo e qualitativamente relevante na determinação dos valores sociais. Assim, a indústria passou a considerar estes interesses e necessidades de consumo. Podemos citar alguns itens como o jeans, a camiseta pólo, os vestidos floridos de algodão e as jardineiras (NOGUEIRA; PICCHETTI, 2011).

\footnotetext{
${ }^{18}$ Jimi Hendrix (1942-1970): músico e compositor norte-americano, considerado um dos maiores guitarristas da história do rock`n roll.
} 


\subsection{Correntes estéticas que influenciaram este movimento}

O Cinema Novo buscava construir um mundo novo através da política, ainda subordinado de certa forma à questão estética. Suas fontes foram principalmente os cineastas Luchino Visconti, Luis Buñuel e Akira Kurosawa (mestres de uma escrita clara e direta, à beira do classicismo). Outros diretores, como Roberto Rosselini e François Truffaut, também foram importantes fontes de inspiração de cineastas específicos e semimarginais.

As origens dos diretores do ciclo Marginal são bem diferentes. Embora a maioria fosse ou se declarasse politicamente progressistas, sua preocupação principal sempre foi à subversão da linguagem cinematográfica. Os marginais surgiram durante o governo militar (diferente dos cinemanovistas, formados no período democrático de Juscelino).

Como a estrutura cinematográfica do Cinema Moderno, a estrutura do Cinema marginal é fragmentária, incompleta, barroca. Os filmes tendem a ser uma sucessão de quadros independentes e momentos privilegiados sobre alguns personagens em um momento importante de sua existência. A integração de estilos diferentes num só filme rompe ao antigo conceito de estilo irreversível e totalitário (SGANZERLA, 2001).

Em entrevista para Alfredo Sternheim, Revista "Filme Cultura" (1967), o cineasta Luiz Sergio Person fala sobre uma característica do cinema paulista, onde cada um tem um cinema desvinculado do outro:

Todo autor, aqui, busca um tipo de cinema que consciente ou
inconscientemente leva a uma pesquisa, a uma temática diversa de outro
realizador. Não há - eu diria uma unidade - mas, uma certa equivalência de
ideias, de aspirações, alguma coisa que pudesse ser o elemento comum de
definição do cinema paulista. Todos eles o são na medida que se
encontram marginalizados e através dessas individualidades diversas, de
objetivos contrários, formam um todo. A Margem, por exemplo, é um filme
inesperado, totalmente diverso de tudo o que já se fez aqui em São Paulo,
da mesma forma que São Paulo S.A, creio, e alguns outros (MORAES,
2010, p. 468).

Segundo João Carlos Rodrigues, as influências do Cinema Marginal parecem vir de Jean-Luc Godard ("Pierrot Le fou" de 1965, "La chinoise" e "Weekend", ambos de 1967); dos neo-expressionistas americanos do cinema B; e das Chanchadas 
(humor ausente no Cinema Novo anterior a Macunaíma ${ }^{19}$ ). E da literatura de Oswald de Andrade, Jorge Mautner, José Agrippino de Paula; da arte conceitual de Hélio Oiticica; da música popular de Mário Reis à Tropicália, passando por Jimi Hendrix; do teatro de Zé Celso. Tinham também entre si diferenças estéticas, fáceis de confirmar se compararmos o cinema agitado de Sganzerla e Trevisan com os constantes silêncios da obra de Bressane e Candeias (PUPPO, 2001).

Na cena final do filme "O Bandido da Luz Vermelha" a guitarra de Jimi Hendrix une-se ao som do candomblé, usado no filme "Terra em Transe" de Glauber Rocha, e assim Ismail Xavier expõe:

\begin{abstract}
No final, a presença-chave do som de Jimi Hendrix, justaposto ao candomblé, define o reconhecimento de uma parcela da nova geração cujo movimento de globalização da experiência teve como via, não a Universidade mas a cultura eletrônica da mídia, a vertente do rock no momento de sua utopia antiautoritária de final da década (militância política e rock não eram excludentes, mas a parcela da juventude focalizada em Terra em Transe era ciosa de sua alteridade face à cultura jovem veiculada pela mídia) (XAVIER, 1993, p.111).
\end{abstract}

A relação do cinema americano com o Cinema Marginal é nitidamente mais forte em São Paulo do que no Rio de Janeiro. O cinema japonês, o qual os cineastas tinham acesso nos cinemas de colônia no bairro da Liberdade, também são citados como grande inspirador. Os cineastas americanos Samuel Fuller, Orson Welles e Alfred Hitchcock, Nicholas Ray, são louvados e plagiados pelos marginais. O filme "O Pornógrafo" de João Callegaro, é recheado de citações do cinema americano, e pode-se ainda arriscar esta influência, na maneira de vestir de alguns personagens, como mostra a figura 28.

A forma pela qual o Cinema Marginal se apropria da narrativa clássica é a "citação", a inserção de trechos inteiros característicos de outras obras dentro da estrutura do filme. Ou a assimilação é realizada através do retrato, de forma estilizada, do universo da ficção próprio da narrativa clássica: a fotografia, a trilha musical, cenários, personagens.

No ciclo Marginal ocorre a verticalização da narrativa, a exploração de situações dramáticas sem que haja preocupação em relacioná-las com outros momentos, posteriores ou anteriores, da ação. A narrativa elabora a ficção sem se preocupar com a disposição espacial ou temporal.

\footnotetext{
${ }^{19}$ Macunaíma: Filme de Joaquim Pedro de Andrade, de 1969, baseado na obra de Mário de Andrade.
} 
Figura 28 - Cena do filme "O Pornógrafo", de João Callegaro, 1970.

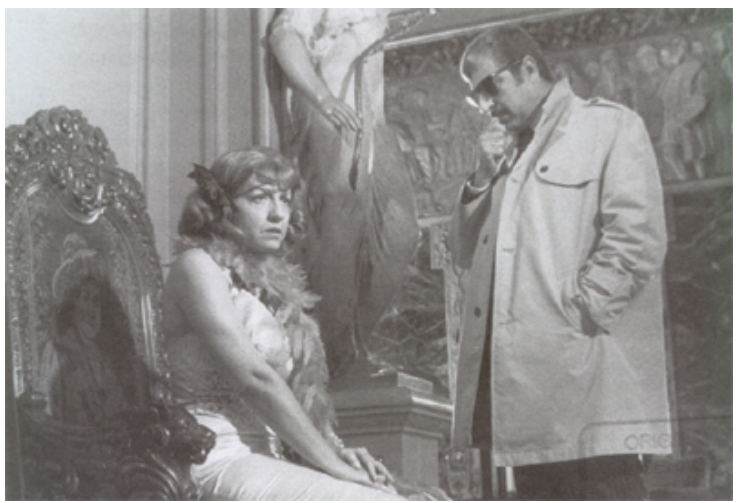

Fonte: RAMOS, 1987

Rogério Sganzerla no texto "Divisibilidade" de 1980 comenta sobre a narrativa no Cinema moderno:

O Cinema Moderno recusa todo desenvolvimento lógico da narrativa: a organização de elementos combinados, dependentes, integrados pela conclusão final e através da qual desenvolvem-se outras personagens gradualmente reveladas em toda sua complexidade, através de frases narrativas; jogos de ação/reação entre os personagens (SGANZERLA, 2001, p.65).

A atração por cineastas e produções classe "B", pelo estilo kitsch, se desenvolve no sentido de criticar a linha "esteticista" do Cinema Novo. Rogério Sganzerla diz em entrevista ao jornal "O Pasquim", que dentre toda a obra de Orson Welles, ele prefere o filme "O Estranho" (figura 29), "que eu não vi mas dizem que é horroroso (...) um filme que em vez de estar baseado no luxo e no equilíbrio do Cidadão Kane, está baseado na miséria, na escrotidão dos atores, na diferença de qualidade, de técnica, de negativo" (RAMOS, 1987, p.76).

Figura 29 - Cena do filme "O Estranho", de Orson Welles, 1946.

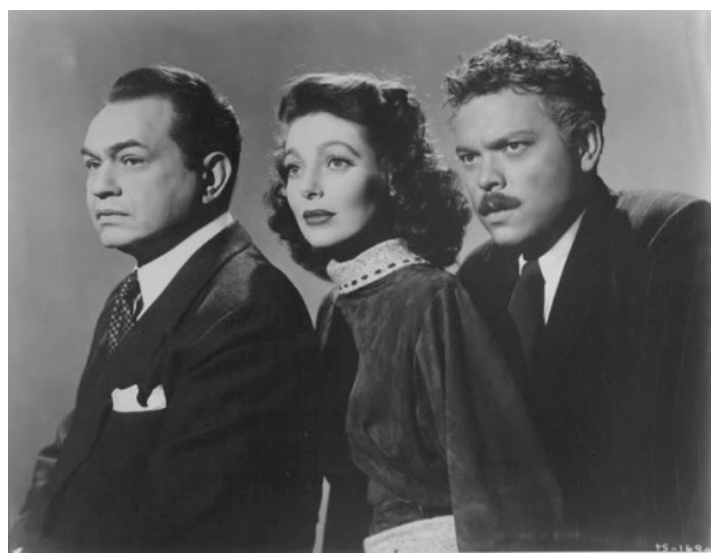

Fonte: http://cinecafe.wordpress.com/2010/10/14/o-estranho-orson-welles-1946/ Acesso em 23/12/2012 
A Pop Art também tem grande influência nos filmes deste ciclo, principalmente na obra de Rogério Sganzerla. Na década de 60, os artistas defendiam uma arte popular ( $p o p)$, com comunicação direta com o público através de signos e símbolos retirados do imaginário que cerca a cultura de massa e a vida cotidiana. A Pop Art acrescentava ao seu repertório, cenas das histórias em quadrinhos, da publicidade, das imagens televisivas e do cinema.

Os principais expoentes deste movimento no mundo são Richard Hamilton, Andy Warhol, Roy Lichtenstein, Tom Wesselmann, entre outros. No Brasil, sugestões foram trabalhadas por Antonio Dias, Rubens Gerchman e Cláudio Tozzi.

$\mathrm{Na}$ esfera cinematográfica, o impacto da Pop Art dependeu muito da influência de Andy Warhol, ocorrida a partir de 1964, o que elucidava uma atenção maior à vertente Pop do cinema experimental. 


\title{
3. O processo criativo na construção do figurino
}

A primeira exibição pública do cinema ocorreu no final do século XIX em Paris, pelas mãos dos irmãos Lumière. As produções eram rudimentares, em geral documentários curtos, cerca de dois minutos sobre a vida cotidiana. Mas é Georges Méliès o pioneiro na utilização de figurinos, atores, cenários e maquiagens, opondose ao estilo documentarista e realizando os primeiros filmes de ficção. A partir de então, o cinema passou a ser disseminado por toda a Europa e depois pelo mundo.

Segundo Sarah Falcão:

\begin{abstract}
O cinema de início tinha como principais funções registrar acontecimentos e narrar histórias. Por ser um registro de imagens valioso, ele também é visto como uma das principais fontes de pesquisa de moda. De início a questão do figurino não era de tamanha relevância, mas a partir do momento em que os filmes passaram a ser produzidos mais cuidadosamente o figurino passou a ter uma grande importância tanto na função de acervo histórico como para dar realismo aos personagens da trama retratada (FALCÃO, 2006).
\end{abstract}

O conceito de "direção de arte" em cinema surge no final da década de 30 , em Hollywood, por exigência de David O. Selznick, produtor do filme "E o vento levou" (1933). A visualização global do espetáculo nas mãos de um único profissional, o production designer, era conveniente ao produtor/autor. William Cameron Menzies foi o primeiro diretor de arte, responsável pela unidade visual de um filme (HAMBURGUER, 2014).

O figurino passa a ter grande relevância dentro de uma narrativa, complementando o personagem, colaborando no entendimento da trama, trabalhando com o imaginário do receptor, e ainda influenciando a moda. O cinema é uma das grandes referências para os profissionais da moda, sobretudo para os estilistas, sendo que os figurinos usados por personagens de alguns filmes passam a ser copiados pelo mundo todo; e não são somente as roupas, é todo um gestual, um comportamento, um estilo de vida. Mesmo quando no Cinema Moderno o espectador não é mais iludido pela tela grande, os personagens estão mais próximos do espectador, ainda assim, muitas referências são buscadas no cinema.

As opções estéticas do figurinista são de suma importância à narrativa, pois estas escolhas têm um papel pertinente na identificação do espectador com o 
personagem. Cada peça de roupa é lida como um signo relacionado a códigos sociais, ou até mesmo fetiches pessoais.

Mas o objetivo do figurinista, responsável pelos trajes de cena numa obra, ao criar figurinos para um filme, é respaldar a história narrada como elemento comunicador. O figurino, além de um elemento comunicador, é um elemento comportamental absolutamente indispensável para os atores. Certos símbolos são mais do que fundamentais para o reconhecimento dos personagens.

O figurino marca a época dos eventos, o status, a profissão, a idade do personagem, sua personalidade e sua visão do mundo. Muitas vezes ele aparece antes do gesto, da palavra. La Motte (2010) trata esse aspecto partindo da questão "Por que as pessoas vestem roupas?" e declara que as razões não mudam, as roupas estabelecem o período, o local, a cultura e as condições. O simbolismo é a raiz da criação dos figurinos, que se tornam metáforas da personalidade de seus personagens, sendo que as roupas refletem suas ações e condições, mesmo aquelas que atuam como pano de fundo e que estabelecem um mundo povoado pelos personagens principais.

Um corpo vestido serve para mudar a imagem do indivíduo. Criar um personagem requer juntar elementos estabelecidos, dispostos a se completarem. As cores, os materiais, as formas, permitem que o corpo apareça, é a roupa, o figurino como meio. O uso de cores e texturas nos figurinos também coopera na dramaticidade e no jogo determinado com os demais personagens.

Alison Lurie em "A linguagem das roupas" (1977) aborda o ato de vestir como uma forma de linguagem própria, uma forma de comunicação não verbal composta por elementos que funcionam como uma espécie de "vocabulário", cujo léxico é composto por cores, formas, tecidos, textura, volumes e modelagens como meio de expressão. O vestuário é talvez o mais eficiente meio de comunicação não verbal que o ser humano usa, nos dias de hoje e há séculos (LURIE, 1977).

Vestir personagens é criar roupas e acessórios para o mundo da ficção, da encenação, da arte. É preciso entender a vestimenta, seus aspectos sociais e culturais, e sua inserção no mundo do espetáculo. É necessário respeitar tipos físicos, emoções, ambições, frustrações, sexualidades.

A pesquisa é uma ferramenta importantíssima para o figurinista, é através dela que este profissional pode reconhecer os usos e costumes de um povo e, a partir daí, conceber figurinos para os personagens. O estudo das formas 
vestimentares revela as condições econômicas e os conhecimentos tecnológicos, os modos de produção, os sistemas de pensamento, organização social e as representações simbólicas da sociedade e dos indivíduos.

O figurino pode ser visto como um instrumento, um veículo para o ator compor seu personagem e, ao mesmo tempo, é a "pele" do ator. Helena Ignez em entrevista para esta pesquisa afirma que o figurino é a "segunda pele" (IGNEZ, 2015). O figurinista deve conhecer os gestos e a postura da época, para dar ao ator os elementos certos para a construção deste personagem. Um figurino mal resolvido pode arruinar uma interpretação e, consequentemente, a trama, o seu entendimento.

\begin{abstract}
Um figurino inadequado pode enterrar duas semanas de ensaio. Um figurino esperto, com um acessório acrescentado à última hora, pode dar aquele toque que faltava numa determinada cena, muitas vezes ensaiada, mas ainda não satisfatória. (...) Figurinos são signos que ajudam a construir personagens e devem participar da unidade dramática de cada papel. Um personagem desleixado deve estar constantemente "malvestido", o que não é o mesmo que estar "feio" (GERBASE, 2003, p.73).
\end{abstract}

\title{
3.1. O processo criativo do figurino no Cinema Marginal de Rogério Sganzerla
}

O que une uma equipe de produção de cinema é a criação de um universo visual, rítmico e sonoro especial, que oferece ao espectador a vivência de uma narrativa. Instrumento essencial da composição do espetáculo, a direção de arte atua sobre um dos componentes centrais de construção da linguagem cinematográfica: seu aspecto visual (HAMBURGUER, 2014, p.18).

A direção de arte de um filme é uma composição plástica compreendendo tanto as características formais do espaço e objetos como a caracterização das figuras em cena. É neste momento que entra o figurino.

Figurinos podem retratar o cotidiano, a realidade e o momento de um país de uma maneira tão realista que, muitas vezes, parecem nem existir, mas nem por isso deixam de cumprir o seu papel como colaborador na dramaturgia. São, de certa forma, o reflexo de uma época.

São poucas as fontes para pesquisar o surgimento do figurinista no cinema brasileiro. Para a diretora de arte Vera Hamburguer, nas décadas de 60 e 70, muitas vezes, os cenógrafos assumiam a concepção e produção de figurino, além das orientações de maquiagem. 
Existem registros de cenógrafos que orientavam a criação dos figurinos, como é o caso de Piero Massenzi (1925-2009), imigrante italiano que trabalhou na Companhia Cinematográfica Vera Cruz e atravessou diferentes momentos e escolas do cinema brasileiro entre as décadas de 50 e 60 (HAMBURGUER, 2014).

O cenógrafo tinha o conceito do figurino, mas quem realizava, confeccionava os figurinos eram as costureiras, a partir de imagens em livros. Tais profissionais também tinham liberdade para criar.

No filme "O Cangaceiro" (1953), de Lima Barreto, os desenhos dos figurinos foram feitos pelo artista Carybé (1911-1997) a partir dos cenários criados por Piero Massenzi. Carybé concebeu os figurinos antes de começar as filmagens. Massenzi completa: "Ele observava o enquadramento feito sobre os cenários e desenhava a cena montada pelo diretor" (HAMBURGUER, 2014, p.99).

Os figurinos e cenários de "Deus e o Diabo na Terra do Sol" (1964) e "Terra em Transe" (1967), ambos de Glauber Rocha, foram idealizados pelo jornalista e cineasta Paulo Gil Soares (1935 - 2000), o qual também assina a direção de arte. Os créditos de Clóvis Bornay (1916-2005), carnavalesco brasileiro, e Guilherme Guimarães, estilista de alta costura, também aparecem como figurinistas em "Terra em Transe". Bornay foi o responsável pelo figurino usado por ele mesmo no personagem "Conquistador Português", e Guimarães criou o vestido branco usado pela atriz Danusa Leão, intérprete da personagem Silvia (figura 30).

A atriz Helena Ignez cita que a mãe de Glauber Rocha, Lúcia Rocha, que era costureira, realizou os figurinos do filme "O Padre e a moça" (1965), de Joaquim Pedro de Andrade, a partir de desenhos do artista baiano Luiz Jasmim (1940-2013). Helena Ignez diz que D.Lúcia acrescentava muito, trabalhando entre a costura e os figurinos. Depois de prontos os figurinos, eles eram envelhecidos com chá (IGNEZ, 2015).

O diretor de arte Clóvis Bueno (1940-2015) comenta que na década de 70, além da cenografia e produção de objetos, ele também preparava os figurinos. Naquela época ele fazia uma visita na casa dos atores e escolhia as peças do seu guarda-roupa, e depois comprava ou confeccionava outras coisas para complementar (HAMBURGUER, 2014).

No filme de Luiz Sergio Person "São Paulo S.A." (1965), observa-se uma inovação para o cinema brasileiro relativa ao figurino. Baseado na indústria de Hollywood, onde grandes nomes da alta costura faziam parcerias com o elenco, 
como exemplo a atriz Audrey Hepburn e o estilista francês Hubert de Givenchy, a produtora do filme Sócine contratou a estilista Regina Tomaso, proprietária da grife de alta costura Confecções Tomaso, para vestir os personagens. Ela preparou um guarda-roupa para ser usado pelas três estrelas do filme (Eva Wilma, Ana Esmeralda e Darlene Glória). O objetivo era ajudar a definir cada personagem por meio do vestuário. No roteiro original do filme, existem anotações feitas pelo próprio diretor em relação às cores e tipos de roupas a serem usadas pelo elenco em algumas cenas (MORAES, 2010).

Figura 30 - A atriz Danusa Leão em cena do filme "Terra em Transe" (1967) vestindo figurino criado por Guilherme Guimarães.

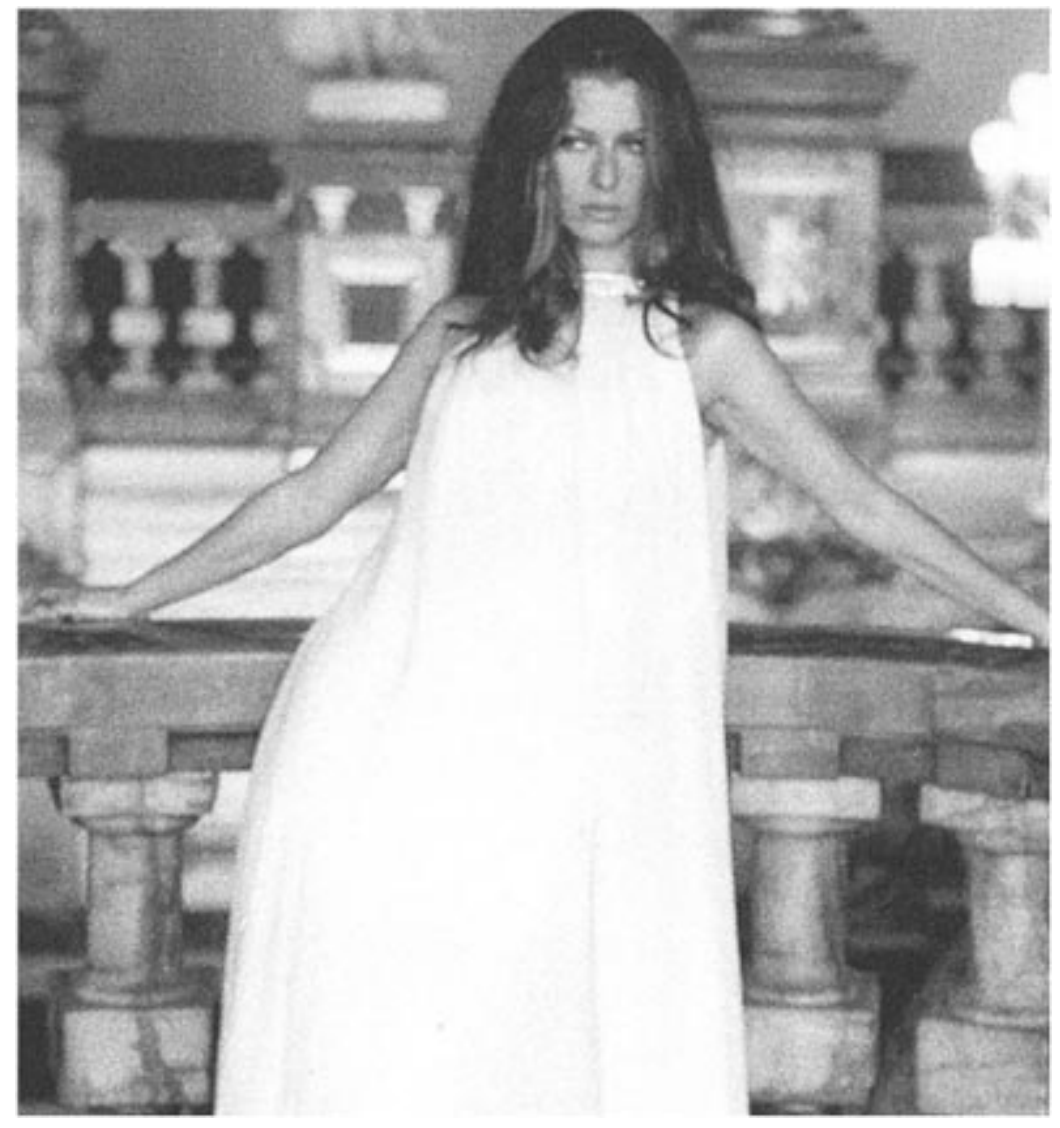

Fonte: http://figurinosebrasilidade.blogspot.com.br/p/terra-em-transe.html Acesso em 20/10/2015

Eva Wilma comenta na entrevista de 18 de junho de 2010, para Ninho Moraes, que se sentiu bem com todas as roupas. Todo o figurino pensado pela estilista Regina Tomaso agradou a atriz e demonstrou o entrosamento da equipe. Isso corrobora a finalidade do figurino (MORAES, 2010). 
Nos anos 60, o estilo de filme de Hollywood também foi desconstruído e redefinido. Estilo e glamour passaram a ter sua inspiração no "grungy non fiction films" e cinema verité, influência francesa da Nouvelle Vague. Os figurinistas procuravam resultados mais naturalistas. Os atores pareciam mais com a plateia do que com os movie stars de antes. E, assim, os espectadores escutavam os personagens.

O "belo" cinematográfico é fazer o espectador acreditar naquilo que vê, são conflitos visuais que tornam a imagem atraente e corroboram a autenticidade do mundo ficcional, muitas vezes excedendo os padrões convencionais de beleza (Hamburguer, 2014).

A "beleza" é um dos ideais que nos conduzem para além do mundo que já é. Seu valor está plenamente contido no seu poder de conduzir. Se já a tivéssemos atingido, ela teria perdido esse poder, e com ele seu valor. Nossa jornada teria chegado ao fim. Não haveria mais nada a transgredir ou transcender, e assim também não haveria vida humana tal como a conhecemos. Mas, graças à linguagem e à imaginação que ela torna tanto possível quanto inevitável, talvez não seja possível alcançar este ponto (BAUMAN, 2005, p. 141).

Sobre o realismo na direção de arte no cinema brasileiro, o diretor de arte Clóvis Bueno completa:

\begin{abstract}
O universo que a gente inventa se transforma em universo real. Trata-se de fazer esse mundo ser convincente, mas não é o realismo contra o fantasioso, é um universo criado para determinada história. Precisamos ser fiéis aos códigos estabelecidos. (...) Esse código não diz respeito exclusivamente à direção de arte, diz respeito ao comportamento do filme como um todo dentro daquele universo (HAMBURGUER, 2014, p.141).
\end{abstract}

No Cinema Marginal, observam-se figurinos tão reais, em alguns casos, simples, em outros, totalmente caricatos. Trajes nem sempre harmoniosos, usados por personagens que representavam a sociedade brasileira.

Alguns créditos de figurinista são encontrados em fitas do Cinema Marginal de acordo com o site IMDb, Internet Movie Database ${ }^{20}$, onde são catalogadas informações pertinentes sobre o cinema dentro de uma enorme coleção. Porém seria necessário aprofundar esta pesquisa para comprovar tais dados. Abaixo alguns exemplos de filmes de diretores do Cinema Marginal onde existem créditos para os figurinistas:

${ }^{20}$ Disponível em http://www.imdb.com/ Acesso em 17/11/2015 
- Gamal, o delírio do sexo (1970)

Direção: João Batista de Andrade

Figurino: Sebastião de Souza

- Os monstros do Babaloo (1971)

Direção: Elyseu Visconti

Figurinista: Hélio Eichbauer

- Bang Bang (1971)

Direção: Andrea Tonacci

Figurino: Lucilla Simon

- O paraíso proibido (1971)

Direção: Carlos Reichenbach

Figurinista: Sylvia de Souza Galante

- Maria... Sempre Maria (1973)

Direção: Ozualdo Candeias

Figurino: Solange Wayand

Segundo relato da atriz Helena Ignez, no bônus do DVD do filme "O Bandido da Luz Vermelha" (2007), era o próprio diretor Rogério Sganzerla quem solicitava o figurino aos atores, que colaboravam com suas roupas pessoais. Ela, inclusive, comenta que um dos figurinos mais extravagantes usado pelo ator Paulo Villaça no filme, "uma calça com estampa de bicho", foi o próprio Villaça quem comprou numa loja da Rua Augusta, em São Paulo. Em 1968, o filme recebeu prêmio de melhor figurino no $3^{\circ}$ Festival de Brasília do Cinema Brasileiro, e o prêmio foi para Rogério Sganzerla.

Para Helena Ignez, Rogério Sganzerla, além de um autor de cinema, era um diretor de arte. No "Bandido da Luz Vermelha", o diretor de fotografia Peter Overbeck também colaborou nesta área e acabou dividindo a direção de arte com Sganzerla. Overbeck vinha da Companhia Cinematográfica Vera Cruz, tinha uma formação sofisticada de luz, de cinema, de cenografia, e assim contribuía com a estética do filme (IGNEZ, 2015).

A atriz relembra que Sganzerla the explicou como queria a personagem vestida no filme "O Bandido da Luz Vermelha", com botas e minissaia. Helena Ignez apresentou ao diretor sua sugestão: uma autêntica minissaia preta acolchoada Mary 
Quant $^{21}$, botinhas brancas Courrèges ${ }^{22}$ e camiseta branca. O diretor, imediatamente, aprovou o figurino e assim surgiu a figura da personagem "Janete Jane" (IGNEZ, 2015).

O figurino era único e foi usado pela personagem quase em todas as aparições dela. A atriz recorda em tom de brincadeira que "só trocava as calcinhas"... Peça íntima sem continuidade no filme. Os figurinos ficavam sob a responsabilidade do ator, pois eram pessoais. Existia uma assistente de direção (não foi citado o nome e não existem créditos no filme) com atenção especial aos figurinos, mas o grande comprometimento era do elenco (IGNEZ, 2015).

Segundo Helena Ignez, o empresário do ramo de perfumaria Aparício Basílio (1936-1992), que era uma pessoa muito ligada à moda e amigo pessoal do ator Paulo Villaça, também indicou onde encontrar alguns figurinos, inclusive a calça de estampa de pele de cobra comprada na Rua Augusta, conforme citado anteriormente. Nesta época, a Rua Augusta era um local com lojas caras e diferenciadas.

Carlos Ebert comenta que a estética do filme "O Bandido da Luz Vermelha" tomou conta da equipe, para ele "todo mundo virou assecla do Bandido". Como todos estavam imbuídos da estética, do espírito do filme, as ideias que apareciam no set eram sempre pertinentes e funcionavam. Era muito bom trabalhar com o Rogério Sganzerla, existia espaço para criação coletiva, ele aceitava as sugestões e adicionava ao filme. O trabalho de equipe foi fundamental, uma conjuntura de pessoas muito talentosas, esforçadas e com foco na realização do filme (EBERT, 2013).

Segundo Ebert, o próprio Paulo Villaça contribuiu muito nos figurinos. Ele foi atrás das roupas, sugeriu muitos elementos. O ator trouxe alguns itens, como um chapelão usado em diversas cenas (figura 31). Algumas peças também foram compradas na Boca do Lixo, um exemplo é a camisa de jabot que o Bandido usa quando prepara sua última bomba (EBERT, 2013).

A farda (figura 32) usada pelo Bandido era emprestada de uma pessoa da equipe que tinha um parente militar. $O$ ator Paulo Villaça era um homem grande e a

\footnotetext{
${ }^{21}$ Mary Quant: (1934) Estilista britânica, considerada a criadora da minissaia. Popularizou o uso deste item do guarda-roupa feminino nos anos 60.

${ }^{22}$ Courrèges: André Courrèges (1923) Estilista francês que revolucionou a alta costura ao lançar sua coleção "Space Age" em 1964, com looks futuristas. Contribuiu para o sucesso da minissaia na década de 60.
} 
farda ficou um pouco pequena, mas isto colaborava com a narrativa, evidenciando que a farda era roubada (EBERT, 2013).

Figura 31 - O Bandido (Paulo Villaça) vestindo o chapelão.

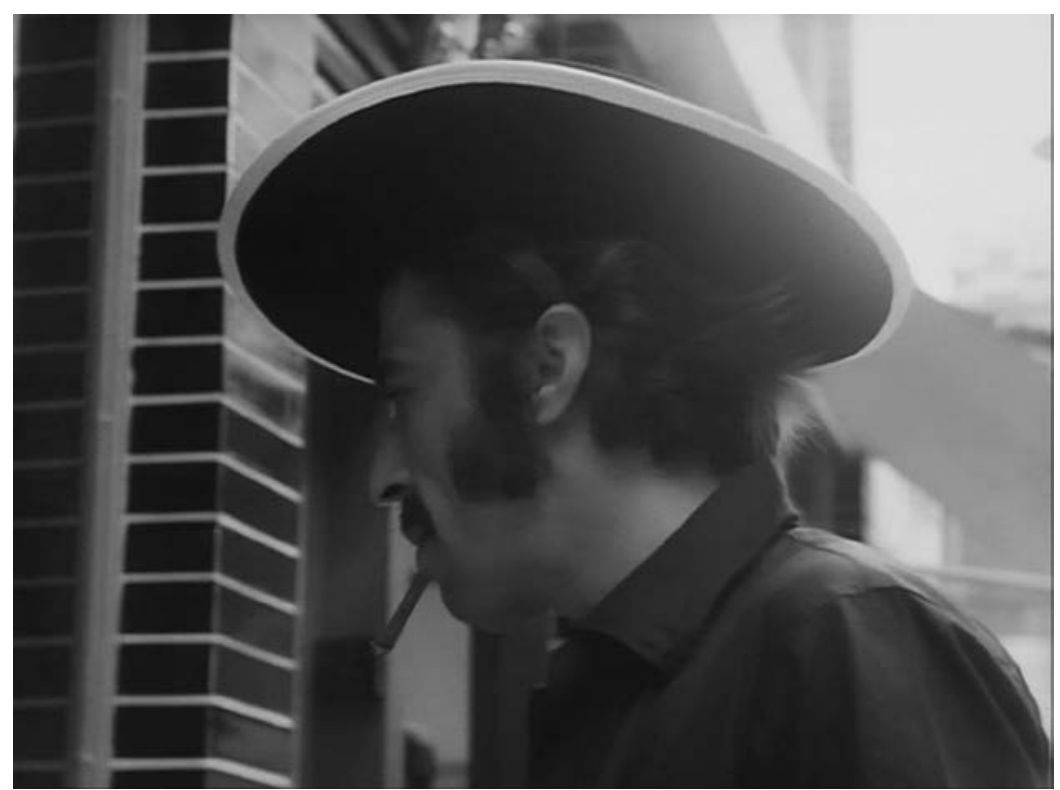

Fotograma do filme "O Bandido da Luz Vermelha"

Figura 32 - Cena em que o Bandido rouba a farda militar no armário de uma de suas vítimas.

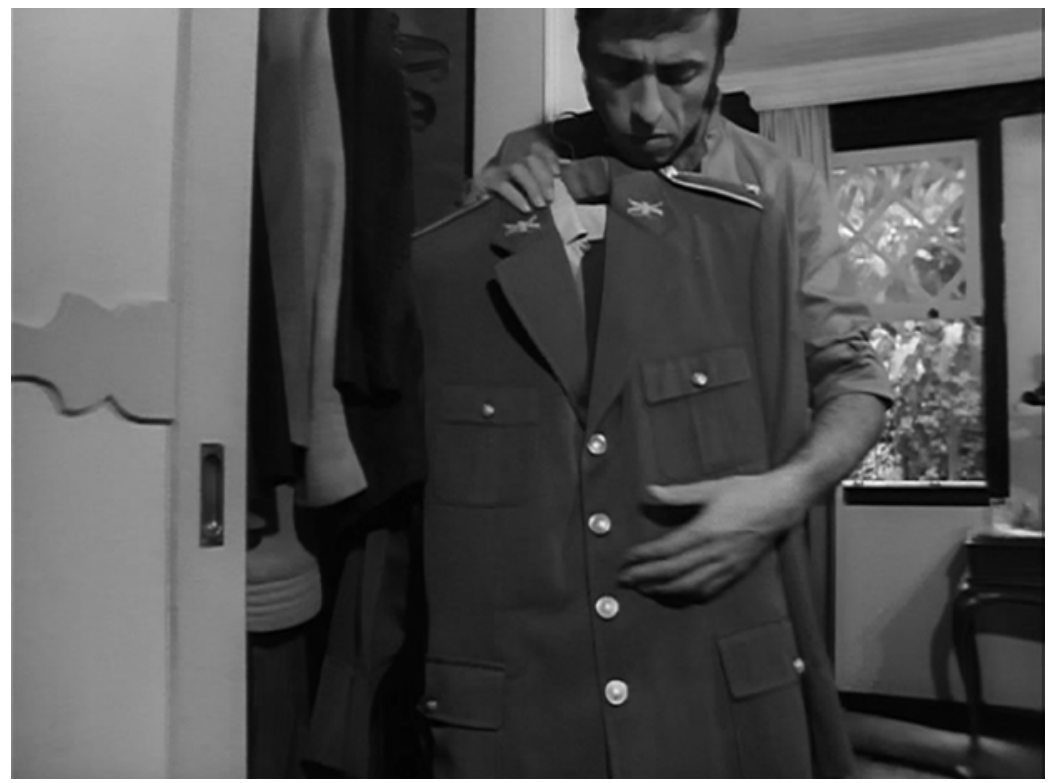

Fotograma do filme "O Bandido da Luz Vermelha"

Carlos Ebert completa, o diretor Rogério Sganzerla fazia uma sobrecarga de elementos sonoros, visuais, sem ser rococó no sentido do excesso. Só entrava na cena aquilo que era expressivo, não existia "uma gratuidade do ornamento". Tudo 
que era acrescentado ao filme tinha uma ligação essencial, radical com a ideia, com o roteiro do filme. E assim o protagonista estava sempre agindo com os objetos de cena (EBERT, 2013).

Helena Ignez comenta em entrevista que na época da "Belair" (produtora de Rogério Sganzerla e Júlio Bressane), ela teve um papel de figurinista, foram sete filmes, onde ela cuidava dos figurinos (IGNEZ, 2015).

De acordo com os depoimentos colhidos, observa-se que o processo criativo dos figurinos nos filmes de Rogério Sganzerla iniciava-se a partir da concepção do diretor. Como disse Carlos Ebert, ele sabia muito bem o queria, mas ao mesmo tempo era uma pessoa muito receptiva às ideias, a equipe e o elenco colaboravam tanto na criação como na busca dos figurinos (EBERT, 2013).

Os figurinos eram apresentados ao diretor e, assim, aprovados. Não existia teste de câmera. O negativo de cinema era muito raro na época e não era possível gastar negativo com testes de figurino, inclusive muitas vezes as cenas eram registradas em takes únicos devido aos custos do negativo.

Rogério Sganzerla tinha em mente os personagens e descrevia aos atores como desejava que eles estivessem vestidos. O elenco, na maioria das vezes, era responsável pelos figurinos e trazia as próprias roupas para compor os figurinos. Em Hollywood, no início do cinema também não existiam figurinistas e os atores vestiam suas próprias roupas.

Segundo o produtor do filme Julio Calasso Junior, quando era passado o horário de chegada no set de filmagem do "Bandido", era solicitado ao elenco que viesse vestido de acordo com as coordenadas (CALASSO, 2015).

Assim como nos filmes de Rogério Sganzerla, o processo criativo do figurino hoje parte das premissas do diretor. Em seguida, cada equipe de profissionais, em diferentes fases de produção, apresenta suas especialidades para construir o filme. Hoje as equipes de produção são bem maiores do que nos filmes marginais.

O diretor do filme, em conjunto com o produtor, escolhe a equipe de filmagem partindo do roteiro. Num primeiro momento, é formado o "tripé" diretor, diretor de fotografia e diretor de arte. A partir destas três visões reunidas, forma-se uma linguagem própria do projeto.

Para Clóvis Bueno "O diretor tem a visão dramática de um filme, o diretor de arte a materializa, e o fotógrafo participa nos dois lados: na parte material quando 
ele ilumina um cenário, e na parte dramática, quando, num movimento de câmera, sublinha ou constrói uma emoção" (HAMBURGUER, 2014, p.140).

Após a formação do "tripé", as equipes de figurino, cenografia, maquiagem e efeitos especiais são formadas e recebem as orientações da direção de arte e assim inicia-se a pesquisa e o trabalho em si. É como se cada um desses profissionais representasse a extensão do olhar do diretor de arte, contribuindo de forma criativa e técnica.

Segundo as entrevistas realizadas, a montagem da equipe no "Bandido da Luz Vermelha" não partiu da formação deste "tripé", inclusive o diretor de fotografia Peter Overbeck entrou no filme depois de iniciadas as filmagens e só então assumiu a fotografia e colaborou na direção de arte.

No processo criativo atual, na maioria das vezes, o figurinista de cinema apresenta ao diretor de arte as pastas de referências com ilustrações, desenhos, imagens, fotografias, amostras de tecidos e acessórios, para definir o repertório de cada personagem. É neste momento que se define o caminho a seguir para cada personagem e o figurinista inicia a busca dos itens para compor os figurinos após a aprovação destas referências. Helena Ignez comenta na entrevista que não se lembra de ter visto algum croquis do "Bandido da Luz Vermelha" (IGNEZ, 2015).

Os artigos do vestuário podem ser encontrados prontos em lojas ou brechós, ou confeccionados. Muitas vezes, após esta fase, é necessário dar um tratamento final aos trajes a fim de proporcionar um desgaste natural às peças, feito através de técnicas de tingimentos. Helena Ignez comentou que no filme "O Padre e a Moça" os figurinos eram envelhecidos no chá. Esta técnica ainda é usada por alguns figurinistas hoje em dia, apesar de existirem processos mais modernos.

Então, no sistema atual, iniciam-se as provas de figurino e os testes de maquiagem. Em alguns filmes são feitos testes de câmera com os personagens devidamente caracterizados. Esta etapa não ocorreu nas filmagens do "Bandido".

O projeto inicial pode sofrer algumas alterações ao longo deste processo, principalmente quando o ator não se identifica com o figurino concebido. Vale lembrar que os trajes devem acomodar não somente as formas e tamanhos do corpo humano, mas também a vida e as reflexões do personagem. O figurinista deve ser receptivo às sugestões e ter flexibilidade para fazer as modificações necessárias sem se distanciar da proposta original. 
Durante as filmagens, a equipe de figurino deve se planejar para que todas as vestimentas estejam em condições de uso e acessíveis ao ator conforme concebido. A presença do figurinista no set é essencial para acertar todos os detalhes, dar o acabamento e, se for necessário, improvisar.

Tudo indica que Rogério Sganzerla era um profissional extremamente detalhista e cuidava de todo o set, muitas vezes exercendo até a função de um assistente de direção dele mesmo, conforme dito por Carlos Ebert em entrevista. Não existiam figurinistas nos seus filmes marginais. Sganzerla era quem concebia a imagem do personagem e solicitava ao elenco que trouxesse os figurinos para sua aprovação. O próprio elenco cuidava dos trajes durante a filmagem, garantindo suas condições de uso e acesso (EBERT, 2013).

O processo criativo do figurino no Cinema Marginal não possuía algumas etapas se comparado com a maneira como é feito hoje. Porém, existia uma grande atenção aos trajes, corroborando sua importância na trama e, assim, pode-se dizer que foi criado um estilo de figurinos nos filmes de Sganzerla, chamado de "criação Sganzerliana", como citado por Helena Ignez (IGNEZ, 2015). 


\section{Análise do figurino no filme "O Bandido da Luz Vermelha"}

A escolha de analisar o filme "O Bandido da Luz Vermelha" no contexto do ciclo Marginal e, em especial a obra de Rogério Sganzerla, não foi aleatória. Existe uma importância, um destaque dado aos figurinos por este autor. Os trajes do filme são bastante impactantes e colaboram com a narrativa, mantendo uma relação evidente com o protagonista da obra.

A proposta de documentar e analisar os figurinos nesta obra-prima, baseia-se no estudo histórico do período e análise fílmica "frame a frame". A partir da fortuna crítica sobre a produção de Sganzerla e estudo de filmes realizados por ele durante este ciclo, alguns critérios são utilizados para caracterizar os figurinos deste longametragem.

É importante ressaltar que ao analisar mais profundamente um filme, surge um grande vilão da crítica do cinema moderno: a subjetividade. A transcrição frequentemente apresenta a opinião do "transcritor", comprometendo a fidelidade de uma tradução racional e objetiva do que era sensorial (CANUTO, 2006).

A análise foi estruturada principalmente partir do ensaio de Jean-Claude Bernadet "O vôo dos anjos: Bressane, Sganzerla" (1990) e, também, das críticas sobre o filme. Bernadet manipula elementos extraídos da psicanálise e faz um estudo dos personagens, que auxilia no entendimento da trama e na escolha estética (BERNADET, 1990).

A configuração visual gera conhecimentos cognitivos associados diretamente à narrativa, como interpretações simbólicas, históricas, sócio psicológicas, entre outras. As propriedades plásticas da cinematografia, em ação sinestésica característica do cinema, despertam os sentidos sensoriais do espectador, atribuindo novos significados à experiência.

A preocupação com os figurinos deve ser a tradução do personagem, seus anseios, seus desejos, a significação de uma determinada cena. É importante entender o figurino de cinema como linguagem visual. Os trajes também podem criar efeitos dramáticos e psicológicos e, assim, a análise das características plásticas da roupa em si, o tecido escolhido, o caimento, o movimento, o volume, a textura, a forma, a cor e outros aspectos auxiliam na compreensão das intenções do autor na concepção da obra visual. 
O figurino enquanto elemento visual contribui para a trama em parceria com a cenografia e iluminação. Ele tem que apoiar o ator na elaboração de seu personagem, um elemento de conexão entre ele e o espectador, transferindo imagens, causando impressões (VIANA, PEREIRA, 2015).

A composição cromática entre cenários e figurinos cria contradições ou consonâncias significativas. Efeitos de fusão entre a figura e o espaço cênico ou a exploração dos contrastes criados entre eles provocam sensações e significações próprias. O ritmo de leitura do nosso olhar sobre a tela também se dá à medida que os olhos acompanham o movimento e a intensidade dos contrastes entre as cores que sobre ela atuam.

Nos filmes, os trajes também servem como uma forma de descrição dos personagens, provocam um sistema de sentidos, onde o espectador tem condições de identificar a situação do personagem, mesmo sem os elementos sonoros. A imagem de uma pessoa é constituída pelo seu formato de rosto, suas feições, sua cor de pele, seu corte de cabelo, penteado, coloração, sua maquiagem, adornos e, no caso dos homens, seus pelos faciais. Esse conjunto faz uma declaração ao espectador de quem é este personagem por meio da linguagem visual.

Os acessórios (anéis, brincos, sapatos, bolsas, chapéus) também são elementos indispensáveis para compor este personagem e reforçar a mensagem sugerida na narrativa. Na história da indumentária, observa-se que os acessórios sempre tiveram forte simbologia, com significados sociais para distinção de classes, ou mesmo representação da sexualidade. Portanto o vocabulário das vestimentas inclui não apenas peças de roupas, mas também estilos de cabelos, acessórios, joias, maquiagem e decoração do corpo.

As transformações pelas quais os personagens passam ao longo da trama também geram mudanças formais ou de tratamento em seus trajes. O personagem pode iniciar o filme com roupas escuras e a montagem do seu guarda-roupa fica mais clara, ganhando luz e brilho, conforme a trajetória dramática do papel.

As escolhas estéticas das vestimentas dos protagonistas e da figuração também colaboram para a criação da atmosfera geral do filme, "determinando a qualidade dos contrastes existentes entre a massa anônima e os corpos centrais da narrativa" (HAMBURGUER, 2014, p.48).

A partir de pressupostos teóricos de Barthes (2009), alguns parâmetros foram destacados para realizar a análise das imagens do figurino no filme "O Bandido da 
Luz Vermelha" produzido pelo cineasta Rogério Sganzerla durante o ciclo Marginal. A análise dos figurinos baseia-se, também, na análise fílmica realizada por alguns críticos de cinema. Desta maneira, foi possível obter uma melhor compreensão estética e psicológica do filme e seus personagens, que auxiliaram no entendimento dos aspectos que influenciaram a criação e escolha dos figurinos.

\subsection{Os critérios utilizados para a análise dos figurinos do "Bandido da Luz Vermelha"}

O desenho de um figurino, as formas arredondadas, as linhas retas, as transparências, oferecem diferentes características do personagem ao espectador. Sensações ligadas à temperatura, peso e volumetria são intensificadas à visão das formas, cores e texturas nos trajes. Para fazer uma leitura dos figurinos usados pelos personagens é necessário recorrer à semiótica.

Roland Barthes, escritor francês, considerado um dos mais importantes críticos literários, fez críticas às atitudes sociais e cotidianas. Trabalhou em uma ciência geral dos signos, foi um grande especialista das linguagens e dedicou seus estudos para o verbal, escrito e visual, com inclinação também artística.

Barthes elege a descrição do vestuário de moda, pois é também um fato social, um elemento incontestável da cultura de massa, e tem a função de divulgar a moda como um sentido. Revistas de moda do ano de 1958-1959, de junho a junho, foram o corpus escolhido pelo escritor francês. Ele apresenta um inventário completo dos traços da moda (inventário de gêneros e inventário de variantes) para analisar a descrição do vestuário de moda. (BARTHES, 2009)

Para Barthes (2009) existem três vestuários. O primeiro é apresentado fotografado ou desenhado, é um vestuário-imagem, a estrutura plástica. O segundo é esse mesmo vestuário transformado em linguagem, descrito, verbal. Existe uma diferença de material e relações entre o vestuário-imagem e o vestuário escrito, que são diferentes da terceira estrutura, o vestuário real. Portanto a mesma peça de roupa possui três estruturas diferentes: uma icônica, uma verbal e uma tecnológica.

O autor nomeia espécies do vestuário as substâncias que são sempre materiais: uma blusa, uma luva, uma gola, podendo ser ora objeto e ora suporte. $\mathrm{O}$ inventário substancial dos objetos e dos suportes coincide com o inventário do vestuário (os nomes dados às peças de roupas). 
O gênero é uma classe de espécies. Entre as espécies do mesmo gênero existem ao mesmo tempo semelhanças e dessemelhanças. As semelhanças incidem sobre a função da espécie de um mesmo gênero, por exemplo, corpete e bustiê têm mais ou menos a mesma funcionalidade no conjunto do vestuário. $E$ as dessemelhanças recaem sobre a forma das espécies.

As variantes qualificam o vestuário e exibem essencialmente uma diferença. As variantes são imateriais; acrescentar uma variante à uma espécie é "interpretar" o real. Os termos das variantes não podem ser atualizados ao mesmo tempo num mesmo suporte, por exemplo, uma gola não pode estar aberta e fechada. Mas uma saia pode ser ampla, macia e longa.

Para obter um inventário completo dos traços da moda, faz-se necessário o inventário das variantes. São trinta variantes distribuídas em oito grupos.

Destas trinta variantes, seis foram eleitas para analisar os figurinos do filme "O Bandido da Luz Vermelha" e corroborar a sua importância na obra de Rogério Sganzerla durante o ciclo Marginal. É evidente que, durante a descrição de um figurino, outras variantes serão citadas, porém será dada ênfase a seis delas:

Variante de forma: encontra-se dentro do grupo variantes de configuração. A forma pode ser rodada, reta, pontuda, quadrada, esférica, alongada, entre outras. Cada termo pode opor-se aos outros e dois critérios acessórios são utilizados para estruturar esta oposição. O critério de paralelismo, ou de divergência, das linhas que participam da forma principal, assim, o reto gera o quadrado, o afilado, o pontudo; e o curvo dá nascimento ao rodado, ao evasê, ao oval. E o critério geométrico, a forma é considerada ora como plana, ora como geométrica: o reto dá o quadrado (plano) e o cúbico (volumoso). Construindo figurinos, a forma do traje é essencial para desenhar a silhueta e dar a postura ao ator. Uma personagem que usa uma saia reta tem um comportamento diferente de outra que usa uma saia rodada, a forma da saia oferece ou não movimentos à atriz diante da câmera.

Variante de movimento: também pertence à configuração. Possui a tarefa de animar a generalidade do traje. A linha da indumentária costuma ser inspirada pela estatura do corpo humano, que é vertical. E a variante de movimento utiliza-se de termos como subido/descido (palavras traduzidas do francês para a língua portuguesa que soam estranhamente aos ouvidos), mas que não devem ser confundidos com alto/baixo, pertencentes à outra variante. Assim, um suéter subido provavelmente é uma blusa de gola alta, mas o importante a ser observado é que a 
peça inteira tem um movimento de aspiração, para cima. Outros adjetivos são incorporados nesta variante, como: esvoaçante, tombado, inclinado, caído, recuado, entre outros. O movimento de um figurino pode completar a composição da cena enquadrada e sugerir ou facilitar a ação. Uma blusa de ombro caído facilita a ação de desnudar-se, por exemplo.

Variante de peso: faz parte do grupo variantes de matéria, que são variantes cenestésicas (consciência que temos do próprio corpo, a representação do corpo), participam da ordem das sensações centrais do corpo humano (térmicas, viscerais, circulatórias, entre outras). O peso é o que define melhor um material e está relacionado à sua rigidez, assim como a transparência à leveza. O denso está associado ao espesso, encorpado, grosso e assim está ao lado da sombra, do esquecimento, do frio; por este motivo. O vestuário com peso compartilha dos sonhos fundamentais do homem, do céu e da caverna, da vida sublime e do enterramento, do vôo e do sono, é com seu peso que um vestuário se torna asa ou mortalha, sedução ou autoridade. Os trajes cerimoniais, muitas vezes, são pesados: a autoridade é um tema de imobilidade, de morte. Diferente dos trajes de bodas, de batizados, que são vaporosos e leves. A leveza é frequentemente eufórica. A estrutura da variante é polar, pesado/leve. O peso de um figurino colabora com o ator, fornecendo a ele os elementos necessários para encontrar o tom do personagem. Ao vestir um sobretudo de lã, o ator, quase que instintivamente, adotará uma postura rígida, austera, pois o figurino terá um peso.

Variante de volume: está dentro das variantes de medida. Esta variante costuma servir para representar uma dimensão global, e por isso é bem mais imprecisa do que o comprimento e a largura. Ela está bastante próxima da variante de ajuste. É avaliada no nível de sua superfície externa e em relação ao espaço geral que cerca o vestuário. A distância de referência se abre para o espaço circundante. O volume aumenta o corpo, tornando-o pouco definido e, em algumas situações tem uma função protetora. A importância do volume pressupõe, segundo certas análises, uma ética da personalidade e da autoridade, enquanto que a do ajuste, uma ética do erotismo. A figura de um personagem está vinculada à forma, como ele se apresenta para o público. A silhueta fotografada na tela está ligada ao volume do figurino, que pode preencher a tela quando for necessário.

Variante de equilíbrio: encontra-se no grupo variantes de distribuição. É a simetria e assimetria. Para existir esta relação é necessário que a variante se 
posicione em referência a um eixo, que pode ser a linha mediana do corpo. Por exemplo, uma peça de roupa é considerada assimétrica quando a linha de transpasse dos lados atravessa de maneira irregular o eixo vertical do corpo ou quando o abotoamento de uma peça é disposto de maneira dissimétrica em relação a esse eixo. A dissimetria torna o produto "desigual" ou "irregular", o que acontece nas estampas dos tecidos. O contraste, quando é baseado na contrariedade simetria/dissimetria, é um intensivo da simetria, ao mesmo tempo reforçada e complicada, pois pressupõe duas linhas de referência. A mulher está mais ligada a simetria do que o homem, talvez porque a inclusão de um elemento irregular num grupo simétrico é símbolo de espírito crítico, de subversão. Assim, a moda incorpora o desequilíbrio com um leve toque, oferecendo um movimento ao vestuário. “(...) o movimento é uma metáfora da vida; o simétrico é imóvel, estéril (...)" (BARTHES, 2009, p.230). O equilíbrio de um figurino é essencial na sua construção, assim como o equilíbrio do quadro a ser filmado, pois é inerente à estética. Quando existe um desequilíbrio no figurino, é provável que o personagem exija este artifício e propositalmente incomode o espectador.

Variante de associação: faz parte das variantes de conexão. A moda dispõe de operadores binários, que fazem sentido com a combinação de dois ou vários elementos indumentários. Duas peças de roupas podem ser consideradas afins, destoantes ou associadas (de uma maneira neutra). O termo afim (combinado com) sugere uma aliança, uma harmonia entre os suportes que os une. Neste caso, podem ser dois elementos do mesmo tecido, cores combinadas, ou quando a ligação é feita de maneira absoluta. A combinação sugere diversas metáforas de afinidade, sobretudo, a do par. O segundo termo, destoante, é raro na moda. O termo associado é neutro, corresponde a uma correlação pura, que já é bem mais frequente. O modo de associação das peças define o personagem numa trama. Através das combinações pode-se fazer uma leitura da classe social, do estilo, do repertório do personagem. Diferente da moda, o destoante é mais comum ao construir figurinos.

Além das variantes citadas acima, o gênero cor também estará presente na análise dos figurinos. No caso do "Bandido da Luz Vermelha", uma película em preto e branco, é possível reconhecer os tons claros e escuros das roupas, e realizar o estudo. As cores podem ser vivas, claras, brilhantes, escuras, sombrias, apagadas, neutras, pálidas. 
O comportamento das cores nos filmes preto e branco depende da iluminação e do fundo. Por exemplo, um fundo escuro iluminado pode sobressair o vermelho; num fundo claro, o vermelho fica preto. O importante é a tonalidade e o contraste. Nos anos 60, de maneira geral, o cinema comercial era colorido e o de arte era em preto e branco.

$\mathrm{Na}$ descrição dos figurinos também foi levado em consideração a textura, a estampa e a padronagem dos tecidos. Num filme preto e branco, estas questões possuem muita relevância. Algumas correlações cromáticas entre figurinos e as locações ainda foram apontadas, indicando fusões ou contrastes entre a figura e o cenário.

A análise dos figurinos no "Bandido da Luz Vermelha", feita na ordem de aparição dos looks, foi realizada com base em cada uma das seis variantes escolhidas, levando em consideração os trajes dos principais personagens listados abaixo:

- Bandido - interpretado pelo ator Paulo Villaça é o protagonista da história. Personagem baseado no verdadeiro Bandido da Luz Vermelha. É o anti-herói.

- Janete Jane - interpretado pela atriz Helena Ignez é a prostituta traidora que se relaciona com o Bandido. É o retrato da femme fatale.

- J.B. Da Silva - interpretado por Pagano Sobrinho, é o clássico político corrupto, gângster e populista, é o Rei da Boca do Lixo. Defende a miséria como maneira de garantir e preservar o folclore brasileiro.

- Delegado Cabeção - personagem de Luiz Linhares, é o policial responsável pelo caso do Bandido da Luz Vermelha.

Também foram explorados os figurinos de alguns personagens com pequena participação, porém com forte poder imagético, tais como:

- "Gay exagerado"

- "Madame Misteriosa"

- "Anão Profeta"

Importante lembrar que a análise dos figurinos se baseia na obra de Barthes, onde o autor considerou fotografias de revistas de moda, nas quais as imagens são estáticas, diferente dos trajes de cinema que possuem movimento. 
Espera-se desta forma, identificar como foram eleitas as vestimentas para as cenas do filme e, de certa maneira, justificar esta escolha.

\subsection{O filme e seu contexto}

Ficha técnica detalhada

Título: O Bandido da Luz Vermelha

São Paulo, Brasil, 1968, pb, 35mm

Companhia produtora: Distribuidora de Filmes Urânio Ltda

Direção, argumento, roteiro, diálogo e direção musical: Rogério Sganzerla

Assistente de Direção: Afonso Coaracy

Direção de Produção: Julio Calasso Jr

Coordenação de Produção: Paulo Rufino, Ivan de Souza

Produção: José da Costa Cordeiro, José Alberto dos Reis e Rogério Sganzerla

Assistente de Produção: Almir Amorim, Vassily Wosniak, Pereirinha

Fotografia: Peter Overbeck e Carlos Ebert

Câmera: Carlos Ebert

Montagem: Sílvio Reinoldi

Assistente Montagem: Jovita Pereira Dias

Continuista: Sandra Abdalla

Sonoplastia: Edmar Agostinho

Sonorização: Odil Fono Brasil

Técnico de Som: Julio Peres Caballar, Orlando Soares Macedo

Maquinista / Eletricista: Wladimir Warnowsky

Narração: Hélio Aguiar, Mara Duval

Duração: 92 minutos.

Elenco Principal: Paulo Villaça, Helena Ignez, Luiz Linhares, Pagano Sobrinho, Roberto Luna, José Marinho, Renato Consorte, Sônia Braga, Itala Nandi, Sérgio Mamberti, Lola Brah, Ezequiel Neves, Miriam Mehler, Maurice Capovilla.

O filme narra a história de um assaltante de residências de São Paulo, apelidado pela imprensa de "Bandido da Luz Vermelha". Sempre auxiliado por uma 
lanterna vermelha, ele possui as vítimas, tem longos diálogos com elas e protagoniza fugas ousadas, desconcertando a polícia ao utilizar técnicas peculiares de ação. O Bandido gasta o fruto do roubo de maneira extravagante e se relaciona com Janete Jane, uma prostituta da Boca, a femme fatale envolvida com o crime organizado. Conhece outros assaltantes, um político corrupto e acaba sendo traído. Perseguido e encurralado, encontra somente uma saída para sua carreira de crimes: o suicídio.

"O Bandido da Luz Vermelha" é um marco e pode ser considerado como o ponto de partida do Cinema Marginal, obra que consolidou o movimento em São Paulo. Dialoga ainda com o terreno em que foi aplainado, porém apresenta elementos radicalmente novos, de ruptura com o quadro cinematográfico da época. É deflagrador deste processo.

Para se entender a riqueza do filme é fundamental que se compartilhe o espírito daquele momento. Sua produção acontece dentro do quadro ideológico do Brasil dos anos 60, onde ocorreu a falência dos projetos revolucionários de transformação social e a relativização de discursos antes homogêneos de pretendida abrangência totalizadora. O contexto histórico resultante da dialética política, da ética e da estética gerou uma onda de escolas conceituais ligadas ao cinema. As barreiras geográficas dos contornos europeus foram rompidas pela crítica e adquiriram seguidores na América Latina e no Underground norteamericano.

O experimentalismo proporcionou uma explosiva liberdade criadora, a busca da ruptura de conceitos e formas ganhou as telas e os filmesmanifestos conquistaram realizadores em todo o mundo. O cinema nunca foi tão poético em discursos sociais e políticos, gerando resultados estéticos quase sempre instigantes (CANUTO, 2006, p. 34 e 35).

Rogério Sganzerla declara no documentário para o Canal Brasil "Rogério Sganzerla: Elogio da Luz", de Joel Pizzini, que "O Bandido da Luz Vermelha" foi rodado em maio de 1968 e lançado um pouco antes de dezembro de 1968, quando acontecia o Al-5, segundo o autor o filme previa uma situação que ainda não existia (PIZZINI, 2004).

"O Bandido da Luz Vermelha" é um filme singular em diversos aspectos por seu ineditismo, por introduzir com certa intimidade a utilização irônica da narrativa clássica, apesar de ser ainda bastante marcado pelo Cinema Novo. Recebe a 
herança desta escola ao tratar a temática do Terceiro Mundo, porém de uma forma anárquica, niilista, exemplificada na frase profética, perturbadora, repetida pelo Bandido diversas vezes no decorrer do filme "O Terceiro Mundo vai explodir. Quem tiver sapato não sobra".

Gêneros comuns ao Cinema Marginal são apresentados neste filme: o cinema noir, o musical, o documentário, a chanchada e a ficção científica aparecem em uma reunião de paródias.

A obra mostra o lado caricato e debochado da miséria, a estética urbana das favelas e a antropofagia como resposta ao nacionalismo incondicional. Reedita com uma linguagem moderna o elogio de um mundo despido socialmente, à margem de uma civilização que aprendeu com o cinema americano as suas vestimentas éticas e morais. O colapso desta sociedade é apresentado (CANUTO, 2006).

O filme narra, nos moldes de um programa de rádio policial, um período da vida do Bandido da Luz Vermelha. O cenário é a Boca do Lixo em São Paulo, um microcosmo do Terceiro Mundo, local onde além da prostituição e do tráfico de drogas, localizavam-se diversas distribuidoras de filmes e produtoras cinematográficas (inclusive a que produziu o filme). A região paulistana conhecida como Boca do Lixo é limitada pelas avenidas São João, Ipiranga, Rio Branco e, ao norte, pelas estações da Luz e Julio Prestes. O Bandido aparece em várias ocasiões assistindo a filmes, saindo ou entrando em cinemas do bairro.

\footnotetext{
É basicamente um filme policial que se vale de linguagem do policial norteamericano série B (o de produção barata): paisagem noturna, asfalto noturno, um cadáver no asfalto noturno, carros que brecam bruscamente, a câmera inclinada, etc. Mas não só O Bandido... inspira-se em inúmeros filmes e cineastas (BERNADET, 1990, p.12).
}

A cidade de São Paulo é vista no filme a partir da Boca do Lixo, aparece imersa na criminalidade e violência. Uma cidade sem fronteiras onde se vive a angústia, onde se lê grafites, jornais (figura 33), cartazes, histórias em quadrinhos e um jornal luminoso, onde se escutam vozes e músicas que vão de Beethoven à guarânia. Compõe-se um folclore urbano repleto de informações visuais e sonoras, nem sempre assimiladas pelo espectador.

O filme dialoga e inseri no seu discurso o mundo industrial e os modernos meios de comunicação existentes na época. Partindo do abandono da postura valorativa (ideologia centrada a compreensão do universo social), agrega o universo 
fragmentário da realidade industrial-urbana e capta os impulsos múltiplos e díspares desta realidade como alimento desejável para a representação.

Figura 33 - O Bandido cobre o rosto com o jornal "O Dia".

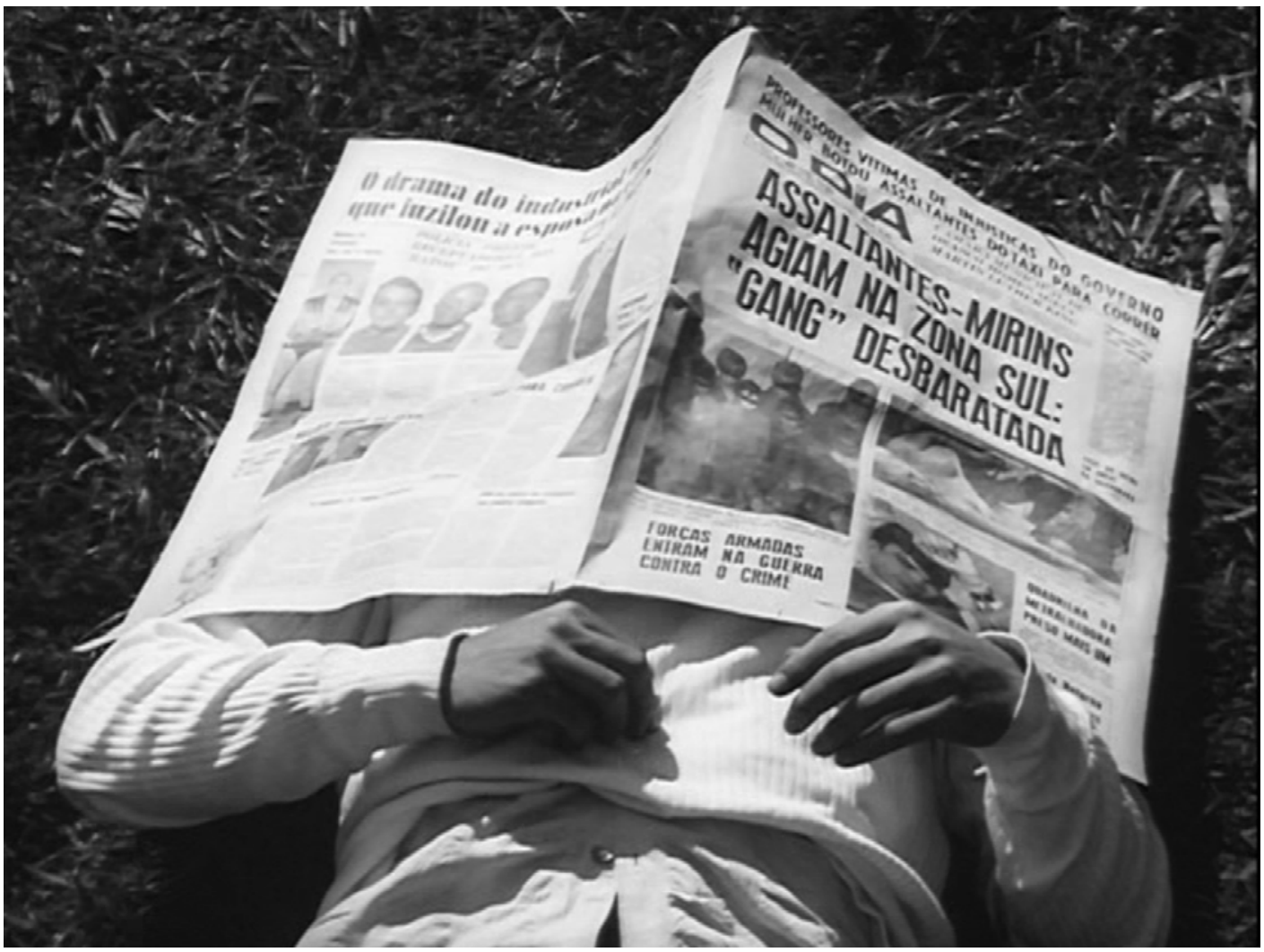

Fotograma do filme "O Bandido da Luz Vermelha"

Entre os elementos urbanos apresentados no filme, pode-se ressaltar: as histórias em quadrinhos, a propaganda, o romance policial, os meios de comunicação de massa (rádio e TV) e suas mensagens (cantores de iê-iê-iê, locutores, galãs, mocinhas apaixonadas), o jornalismo sensacionalista, o próprio cinema com sua vertente mais consumista, entre outros (RAMOS, 1987).

Em O Bandido da Luz Vermelha, o personagem central declara entre agonia e ironia: "Eu tinha que avacalhar, um cara assim só tinha que avacalhar para ver o que saía disto tudo; era o que eu podia fazer". O desprendimento do Cinema Marginal com relação às formas de compromisso e expectativas sociais permite um afrontamento radical com a sociedade institucionalizada que, às vezes, beira o histerismo (RAMOS, 1987, p.43).

"O Bandido da Luz Vermelha" é um filme que trabalha a fragmentação, o corte. A montagem é quem rege o tempo e o espaço. A montagem descontínua 
(desmontagem) é uma característica da Nouvelle Vague francesa, italiana e japonesa. Utiliza-se de sonância, consonância e dissonância.

O protagonista, interpretado por Paulo Villaça, declara diversas vezes ser um "boçal", que é construído de maneira a realçar o seu lado mais imoral, apontando para um individualismo mesquinho. A relação com o espectador permanece com certa distância, onde ocorre uma irritação com o representado.

Observa-se no filme a relação com o cinema americano e em especial com o filme policial. É travado um diálogo intenso com a narrativa clássica. O gênero americano exerce um inegável fascínio sobre Rogério Sganzerla.

1 - Meu filme é um "far west" sobre o III Mundo. Isto é, fusão e mixagem de
vários gêneros. Fiz um filme-soma: um 'far west' mas também musical,
documentário, policial, comédia (ou chanchada?) e ficção científica. Do
documentário, a sinceridade (Rosselini); do policial, a violência (Fuller); da
comédia, o ritmo anárquico (Sennett, Keaton); do 'western', a simplificação
brutal dos conflitos (Hawks), assim como o amor pelos grandes espaços
(Mann). 2 (...). 3 - Orson Welles me ensinou a não separar a polícia do
crime. 4 - Jean-Luc Godard me ensinou a filmar tudo pela metade do preço.
5 - Em Glauber Rocha, conheci o cinema de guerrilha feito à base de
planos gerais. 6 - Fuller foi quem me mostrou como desmontar o cinema
tradicional através da montagem. 7 - Cineasta do excesso e do crime, José
Mojica Marins me apontou a poesia furiosa dos atores do Brás, das cortinas
e ruínas cafajestes e dos seus diálogos aparentemente banais. Mojica e o
cinema japonês me ensinaram a saber ser livre e - ao mesmo tempo -
acadêmico. Ao demolidor devo a metade da minha liberdade e a ele dedico
todos os meus travellings talentosos. 8 - O solitário Murnau me ensinou a
amar o plano fixo acima de todos os travellings. 9 - É preciso descobrir o
segredo do cinema de Luís poeta e agitador Buñuel, anjo exterminador. 10
- Nunca se esquecendo de Hitchcock, Eisenstein e Nicholas Ray (...)
(BERNADET, 1990, p.198).

Esta somatória, mencionada pelo cineasta no "Manifesto" acima surge no filme através de mecanismos de citação onde outros discursos, não só cinematográficos, são incorporados na narrativa antropofagicamente. Isto pode ser identificado na voz off do narrador que remete ao universo da transmissão radiofônica sensacionalista; na velocidade e na forma características do filme policial, através da qual a narrativa se desenrola.

Em entrevistas dadas na época do lançamento do filme, Sganzerla chegou a elencar mais de vinte filmes em quem se inspirou. A cena do suicídio baseia-se no suicídio do personagem interpretado por Jean-Paul Belmondo no filme "O demônio das onze horas" ("Pierrot Le fou", 1965). A traição de Janete Jane, a amante prostituta do Bandido, sugere a traição do bandido pela amante em "Acossado" ("A bout de souffle", 1960), ambos de Jean-Luc Godard. A construção fragmentária do 
enredo e a busca de identidade do Bandido também estão presentes no filme "Cidadão Kane" (1941), de Orson Welles.

A obra é como um mosaico, onde são vistos trechos de diversos filmes, como nos momentos que o Bandido vai ao cinema; material de televisão, como os discos voadores no final do filme. No início e no final da fita, escuta-se os cantos afrobrasileiros de Terra em Transe (1967), de Glauber Rocha.

O Bandido... organiza a sua linguagem de modo a que o material que poderia ficar dispersivo se articule coerentemente. O filme é como o bandido: compõe-se de mil roupagens, só que o filme consegue - e é a sua indiscutível grandeza - estruturar uma linguagem que permite adquirir uma identidade (BERNADET, 1990, p.20).

O longa-metragem não é uma biografia do verdadeiro assaltante e assassino João Acácio Pereira da Costa, mostrado na figura 34, o qual a polícia teve dificuldades em identificar e prender em agosto de 1967, trata-se apenas de uma fonte de inspiração.

Figura 34 - Retrato do verdadeiro Bandido da Luz Vermelha, João Acácio Pereira da Costa, após ser capturado em 1967.

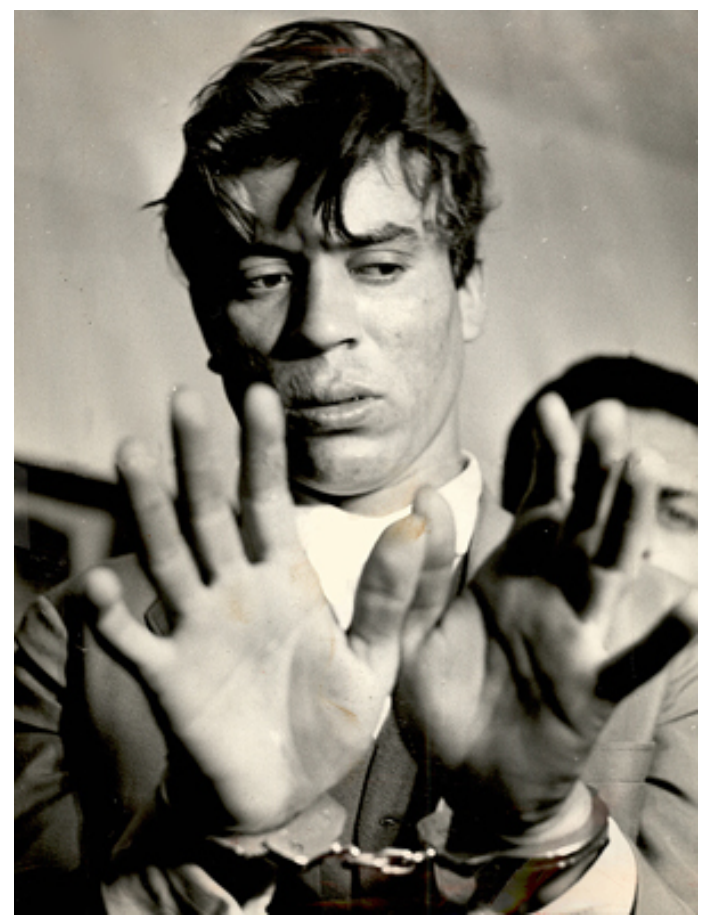

Fonte: http://f5.folha.uol.com.br/saiunonp/2013/10/1349858-o-temido-bandido-da-luz-vermelha.shtml Acesso em 20/12/2015.

João Acácio Pereira da Costa nasceu em Joinville, Santa Catarina, em 1942. Tornou-se órfão ainda criança e foi morar com o tio, onde sofreu maus tratos. Fugiu 
de casa e decidiu viver na rua quando começou a cometer pequenos delitos, como roubo de roupas em lojas para saciar sua vaidade (FERREIRA, 2013).

No início da década de 60 mudou-se para a cidade de Santos em São Paulo. Viajava para a capital paulista para praticar assaltos. Neste período foi considerado um dos bandidos mais temidos de São Paulo, pela forma impetuosa com que agia diante das vítimas. O criminoso gastou boa parte do dinheiro dos roubos com mulheres e boates na Baixada Santista (FERREIRA, 2013).

Em 1967, quando foi preso no Paraná, havia cometido setenta e sete assaltos, quatro homicídios e sete tentativas de morte. Foi condenado a 351 anos de prisão. Após cumprir 30 anos de prisão, dos quais os sete últimos foram passados em um manicômio, foi solto no final de 1997. Menos de cinco meses após sua liberdade foi morto em Joinville com um tiro na cabeça por um pescador que confessou o crime (FERREIRA, 2013).

\subsubsection{O figurino}

O "Bandido da Luz Vermelha" inicia com um luminoso onde algumas frases são exibidas diante da tela como: "um gênio ou uma besta" - referência à polêmica que envolveu os modernistas Oswald e Mario de Andrade, questionando se eles eram "gênios ou bestas". Em seguida uma voz off diz: "Quem sou eu?", que será repetida diversas vezes ao longo do filme. O luminoso avisa que os personagens não pertencem ao mundo, mas sim ao Terceiro Mundo (figura 35), referindo-se à Boca do Lixo, para neste momento anunciar o nome da produtora. Logo após entra o título do filme (invertido no reflexo da janela de um carro), e depois o crédito do diretor com a frase "um filme de cinema de Rogério Sganzerla".

Um locutor e uma locutora narram o filme para os espectadores, mas não para os personagens. A primeira informação passada refere-se ao próprio filme com uma das frases mais famosas do autor: "Trata-se de um faroeste sobre o Terceiro Mundo". A partir daí entram os créditos dos atores. O som do ritual de candomblé, vindo de "Terra em Transe" (1967), de Glauber Rocha, é utilizado para dar eco à expressão "Terceiro Mundo". 
Figura 35 - Luminoso em cena do filme.

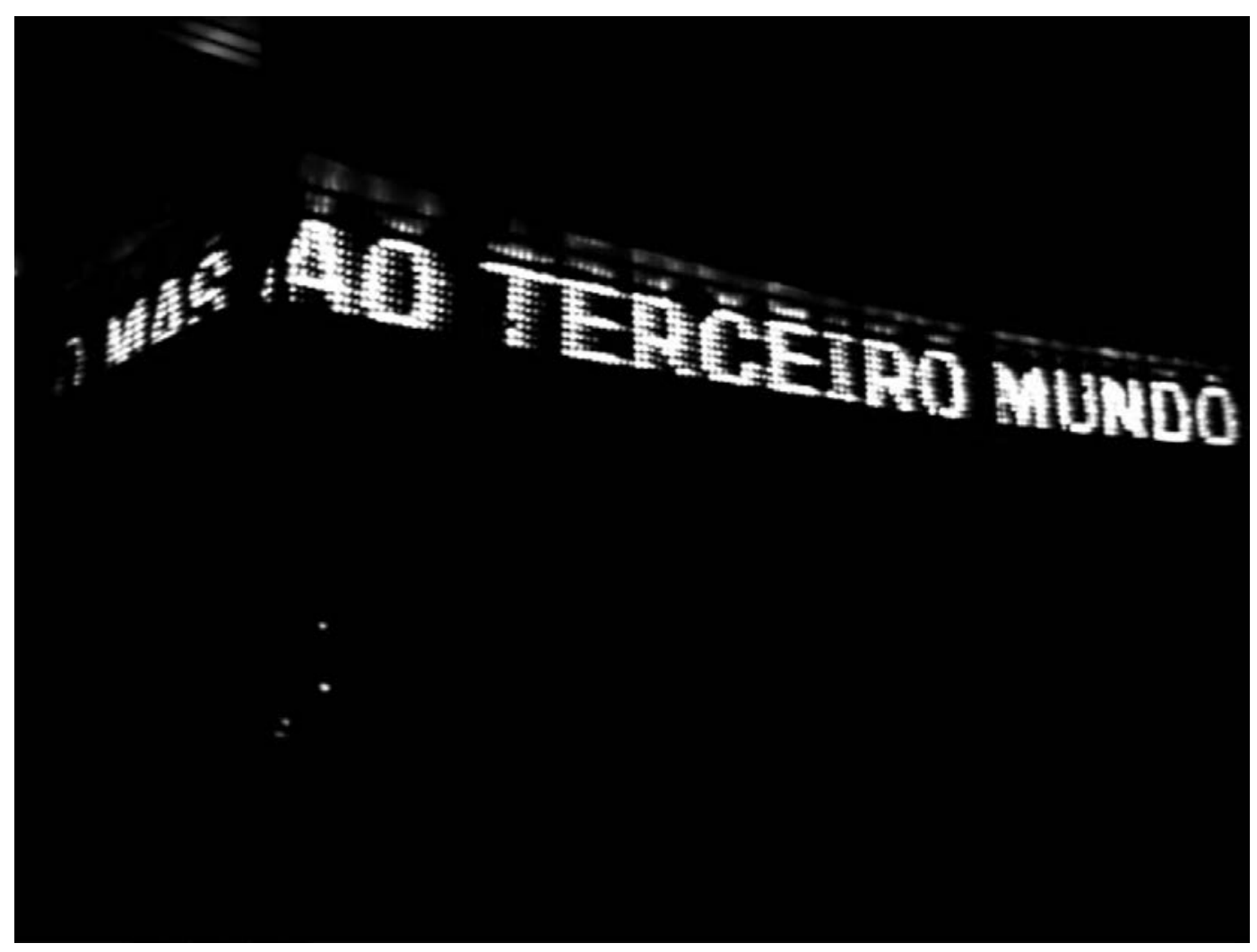

Fotograma do filme "O Bandido da Luz Vermelha"

A primeira sequência do filme é um monólogo em off do Bandido, onde ele dá informações biográficas a seu respeito. Enquanto isso é apresentado na tela um plano geral da cidade de São Paulo, um grupo de meninos e adolescentes pobres com armas de brinquedo num lixo da periferia, crianças assaltando favelas, simulando atirar. As roupas são desgastadas, rasgadas, envelhecidas. Algumas peças estão fora do tamanho das crianças, para acentuar a pobreza. Estampas geométricas tecem o quadro (figura 36). Algumas crianças estão sem camisa e outras descalças. Sganzerla compôs um cenário miserável destituído de moral, onde os habitantes do "lixão" carregam o mesmo cinismo da classe média, alienada e fútil, sob a mira do Bandido.

Quando o Bandido aparece, veste uma camiseta clara canelada manga curta, fotografada como branca, óculos escuros e uma calça clara. A camiseta é justa, revelando o corpo do ator, sua barriga malhada e seus braços fortes. A calça é estreita, sem volume, aliás, quase todos os figurinos do Bandido são desprovidos de volume. O figurino é regular e só existe contraste nos óculos escuros, que completam o look como uma forma de mascarar o personagem (figura 37). 0 acessório sublinha a caracterização do protagonista. 
Figura 36 - Criança na favela, habitante do "Lixão".

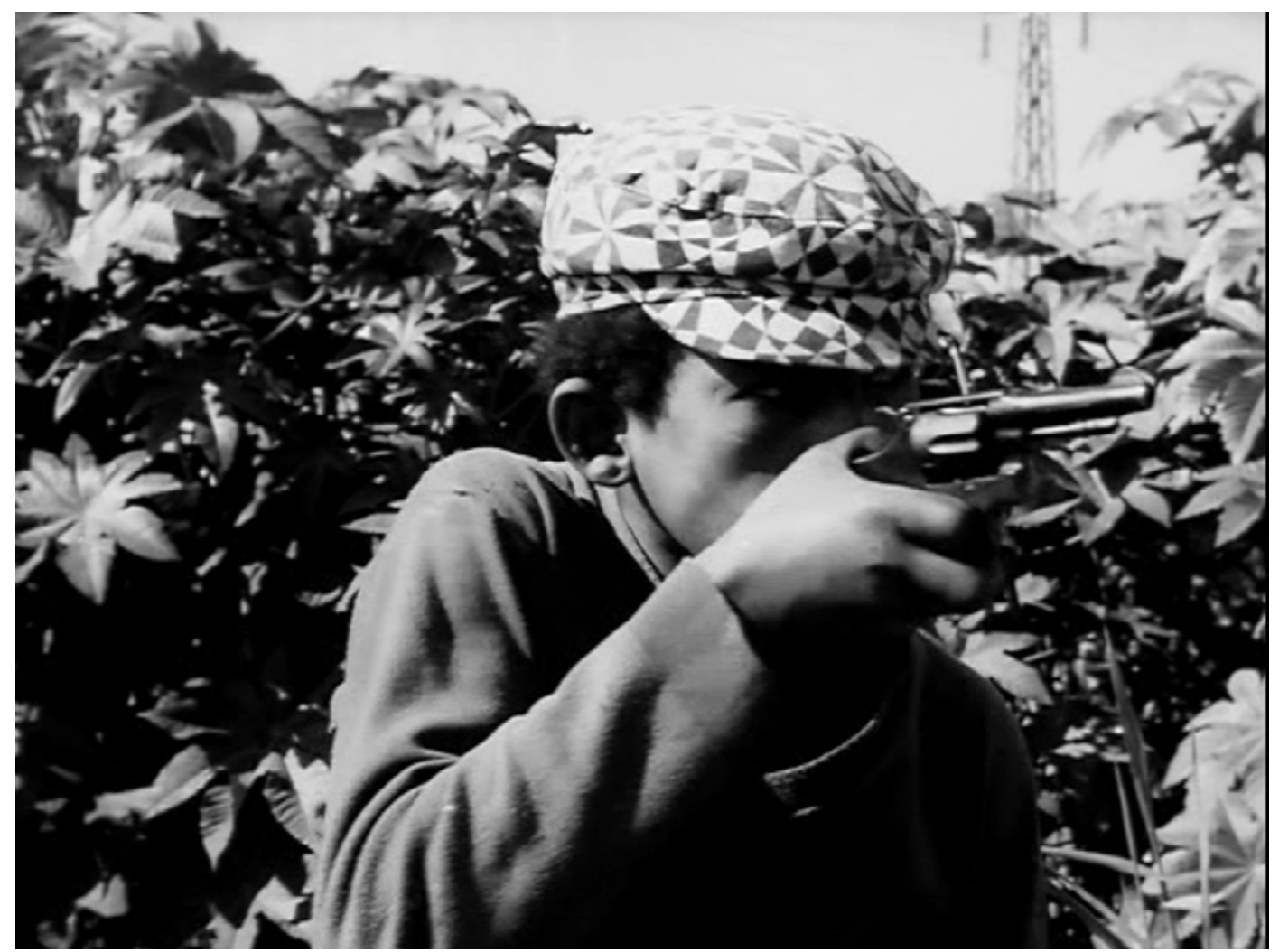

Fotograma do filme "O Bandido da Luz Vermelha"

Figura 37 - Primeiro figurino do protagonista no filme "O Bandido da Luz Vermelha"

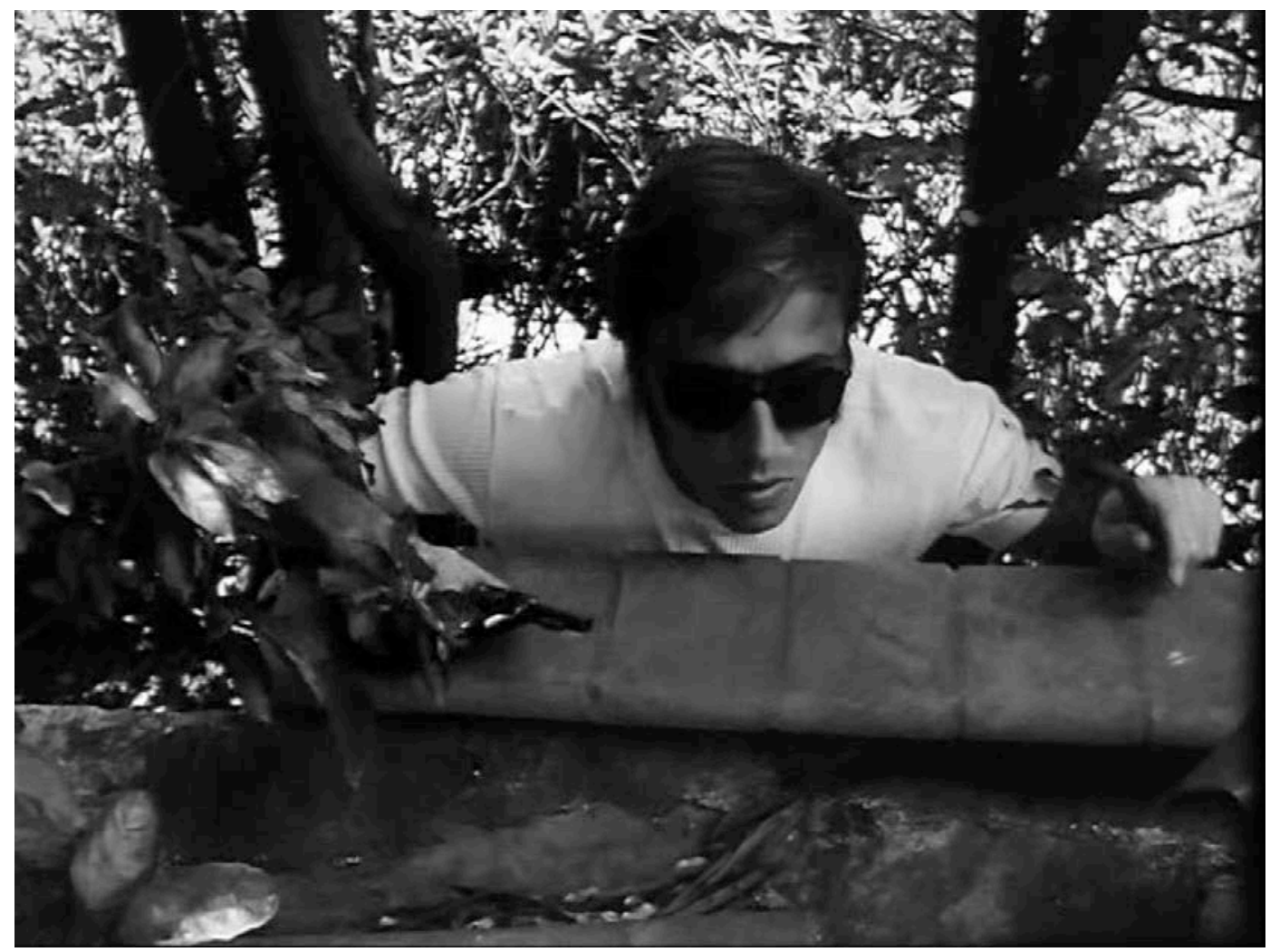

Fotograma do filme "O Bandido da Luz Vermelha" 
A questão da identidade do Bandido transcorre o filme todo e os locutores introduzem diversos adjetivos para ele: "monstro mascarado", "zorro dos pobres", "misterioso tarado", "criminal maconheiro", "um personagem sanguinário, abusivo, bárbaro e arbitrário", "um típico selvagem do século XVI jogado em plena selva de concreto", "um brasileiro à toa na maré da última etapa do capitalismo".

Os dados biográficos fornecidos pelo Bandido são contraditórios. Diz que saiu da favela do Tatuapé, mas sua história começou em "Asunción", Paraguai e continuou no Brasil. Outros dados sobre a sua origem são lançados: "bisneto de Chico Diabo, o brasileiro que matou o presidente Solano López na guerra do Paraguai", "primo de Mineirinho" (famoso bandido que foi tema do filme "Mineirinho, vivo ou morto", 1967), e "afilhado de crisma de Dom Helder Câmara". Quanto à sua nacionalidade, os locutores hesitam entre brasileiro, paraguaio, mexicano ou cubano. Diversos nomes são atribuídos ao Bandido, tais como Ari Galante, Jorge Vargas, Peres Prado ou Jorginho, como é chamado por sua namorada Janete Jane, interpretada por Helena Ignez. Profissões ou atividades mais diversas são atribuídas a ele: campeão de tiro, bicampeão de futebol de salão, falso vendedor de livros, fazendeiro, garçom, corredor porteiro de cinema de terceira classe, bancário... (BERNADET, 1990).

No primeiro assalto do Bandido, logo após vasculhar alguns pertences da casa da vítima, ele aparece usando um colar de bolas feminino, mostrado na figura 38. Apesar do roteiro ser apenas inspirado no bandido João Acácio, algumas características do assaltante são incorporadas pelo personagem do filme. O fetichismo com as roupas era uma característica de João Acácio, quase uma obsessão do bandido. A transformação do seu visual levava as vítimas a descrevê-lo de maneiras muito diferentes, uma forma de confundir a polícia. João Acácio costumava assaltar lojas de roupas, e quando foi capturado estava com quatro malas cheias de roupas de boa qualidade. No seu apartamento, foram encontradas roupas qualificadas pelos jornalistas de finas ou de exóticas, pares de botas, um par de luvas de pelica ou luvas de boxe, e notas fiscais de serviços em alfaiates, tinturarias e despesas em joalherias. Nota-se que os figurinos do protagonista do filme tiveram forte influência das roupas vestidas por João Acácio, como cita Bernadet: 
Num depoimento, João Acácio diz que, por ocasião de um assassinato, estava vestido de terno cinza, camisa de rendas, colete vermelho, gravata de veludo também vermelha e botinhas brancas. Após a prisão, numa acareação na polícia, veste smoking de lapela acetinada, botas brancas e camisa rendada; pediu que the fossem entregues essas roupas para o interrogatório, condição aceita pela polícia, pois lhe fazia as vontades para obter mais informações (BERNADET, 1990, p. 193).

Figura 38 - O Bandido usando um colar feminino de uma de suas vítimas.

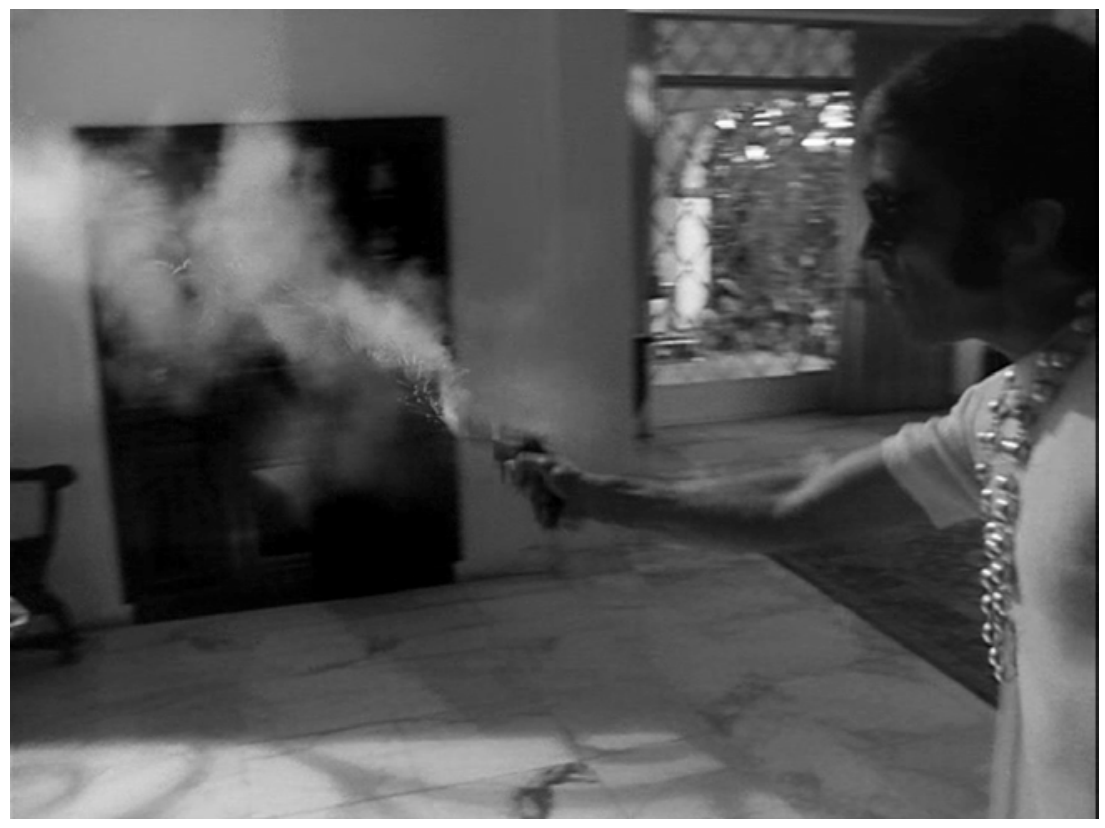

Fotograma do filme "O Bandido da Luz Vermelha"

Logo em seguida o Bandido aparece dentro de um carro, em cena noturna, dando tiros pela cidade. Ainda usa o mesmo figurino inicial, acrescido de um blazer com microtextura, fotografado um cinza médio. O figurino está num tom sobre tom com o interior do automóvel e, assim, dá destaque às feições do Bandido. É possível notar que as mangas do blazer são um pouco curtas para os braços do ator e o tecido não é tão pesado, de maneira que forma alguns vincos como pode-se observar na figura 39.

Após esta sequência, o Delegado Cabeção, interpretado pelo ator Luiz Linhares, aparece na tela grande fazendo uma ronda noturna pela cidade. Quando ele está dentro da viatura, veste os óculos. O uso de óculos escuros, mesmo em cenas noturnas, compõe o figurino de vários personagens do filme, como é possível ver ao longo da trama. Ao sair do carro, o Delegado ainda está de óculos, para logo em seguida tirá-los em cena, como mostram as figuras 40, 41 e 42. Neste caso o acessório serve como extensão do personagem, oferecendo uma ação ao ator. 
Durante toda a narrativa, em suas aparições, o policial irá vestir e tirar os óculos enquanto atua. No cinema americano, os investigadores e os policiais na maioria das vezes são caracterizados usando óculos escuros. O cigarro na boca também indica os personagens durões do cinema noir. O figurino do delegado é um casaco escuro com botões dourados, pesado, provavelmente em lã, comprovando sua autoridade. A camisa clara tem o colarinho desabotoado, demonstrando o lado relaxado do personagem, que usa uma gravata riscada verticalmente, compondo o enquadramento que é de baixo para cima.

Figura 39 - O protagonista dá tiros pela cidade dentro de um automóvel.

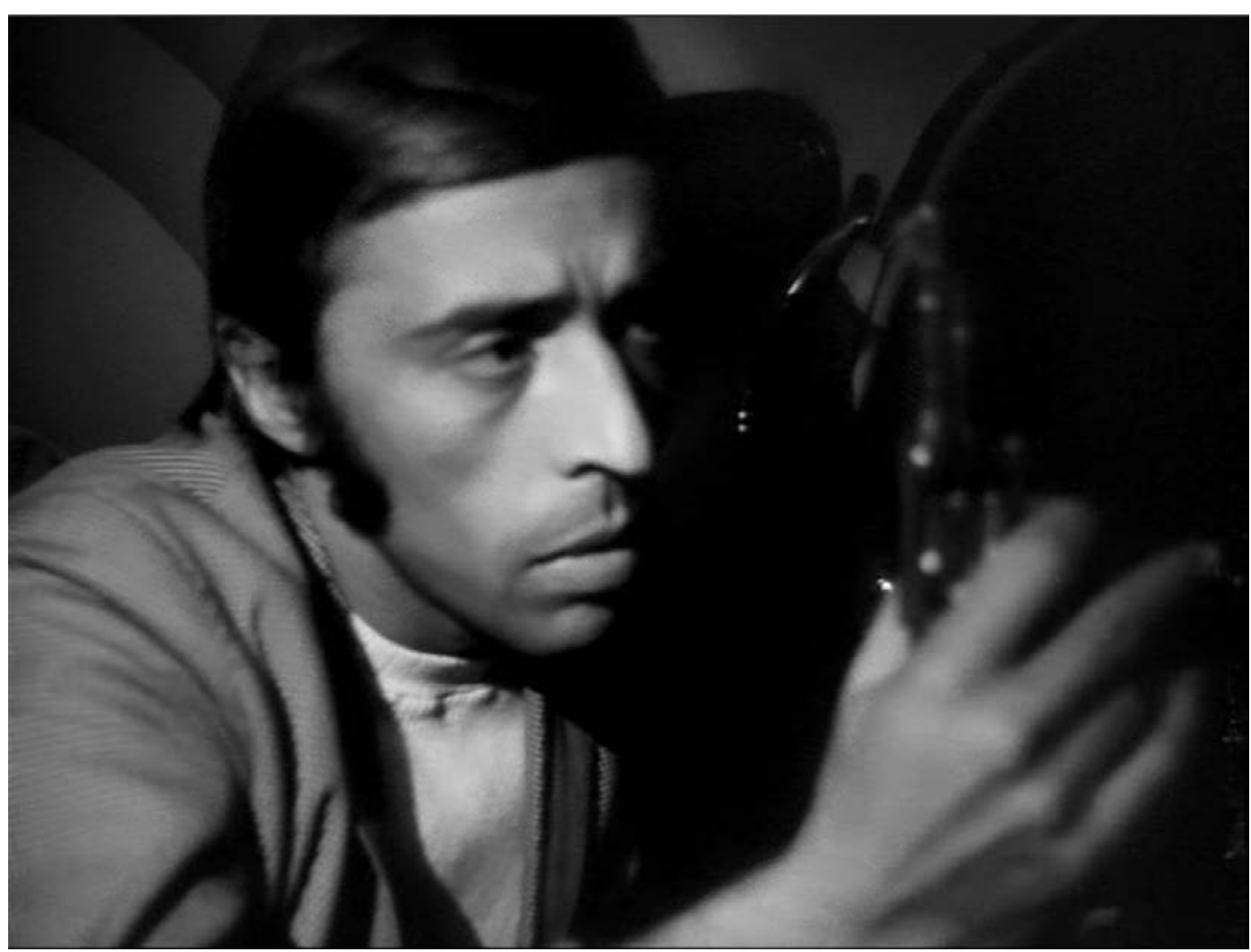

Fotograma do filme "O Bandido da Luz Vermelha"

$\mathrm{Na}$ figura 42 também pode-se observar que o assistente do Delegado Cabeção vestiu um chapéu estilo Panamá e um cachecol xadrez enquanto o policial falava e tirava os óculos. Isto mostra como o diretor Rogério Sganzerla dava diversas ações aos personagens, citado, anteriormente, pelo fotografo Carlos Ebert (EBERT, 2013). 
Figura 40 - Delegado Cabeção veste os óculos dentro da viatura de polícia.

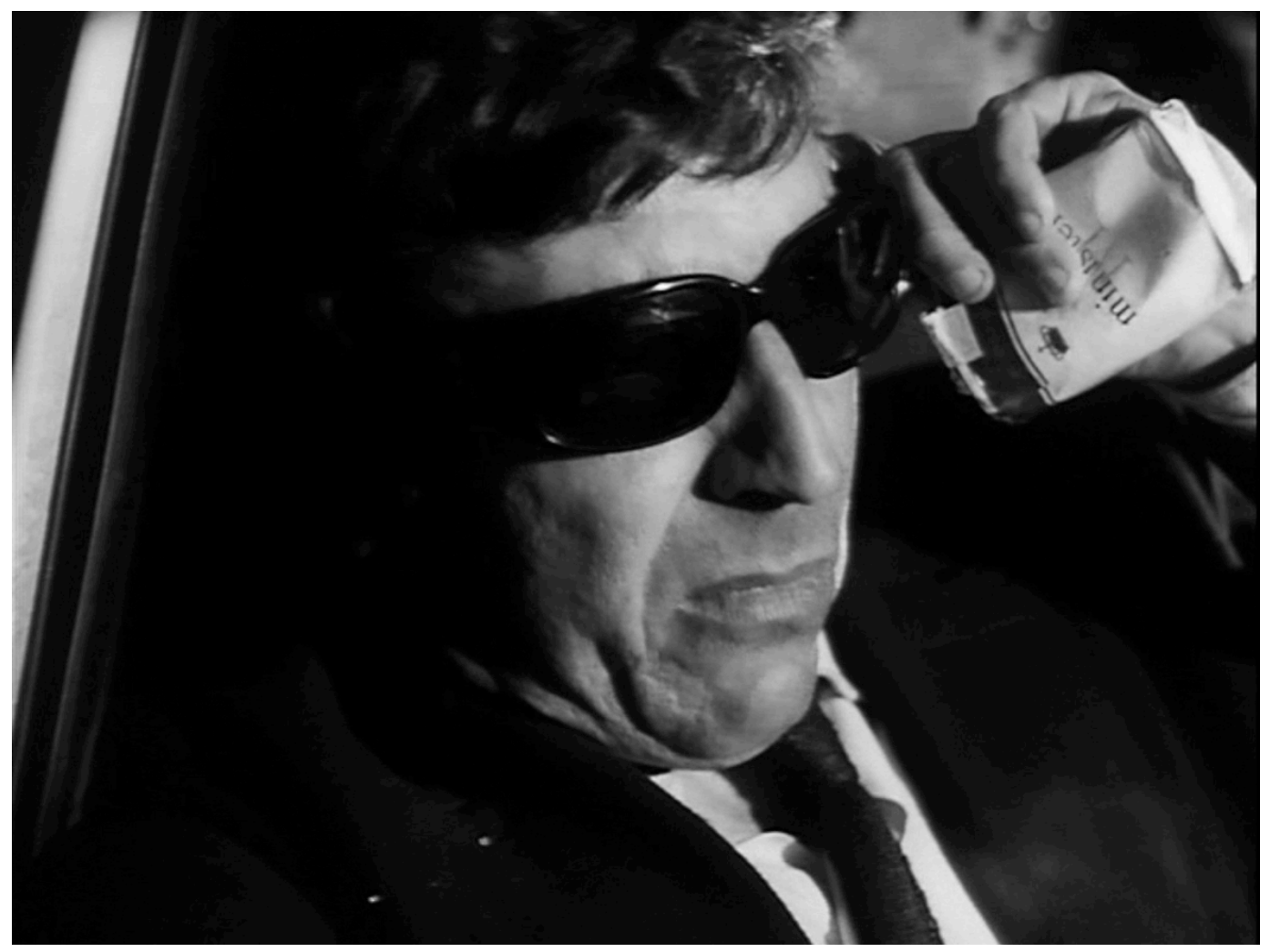

Fotograma do filme "O Bandido da Luz Vermelha"

Figura 41 - Delegado Cabeção usando óculos em cena noturna.

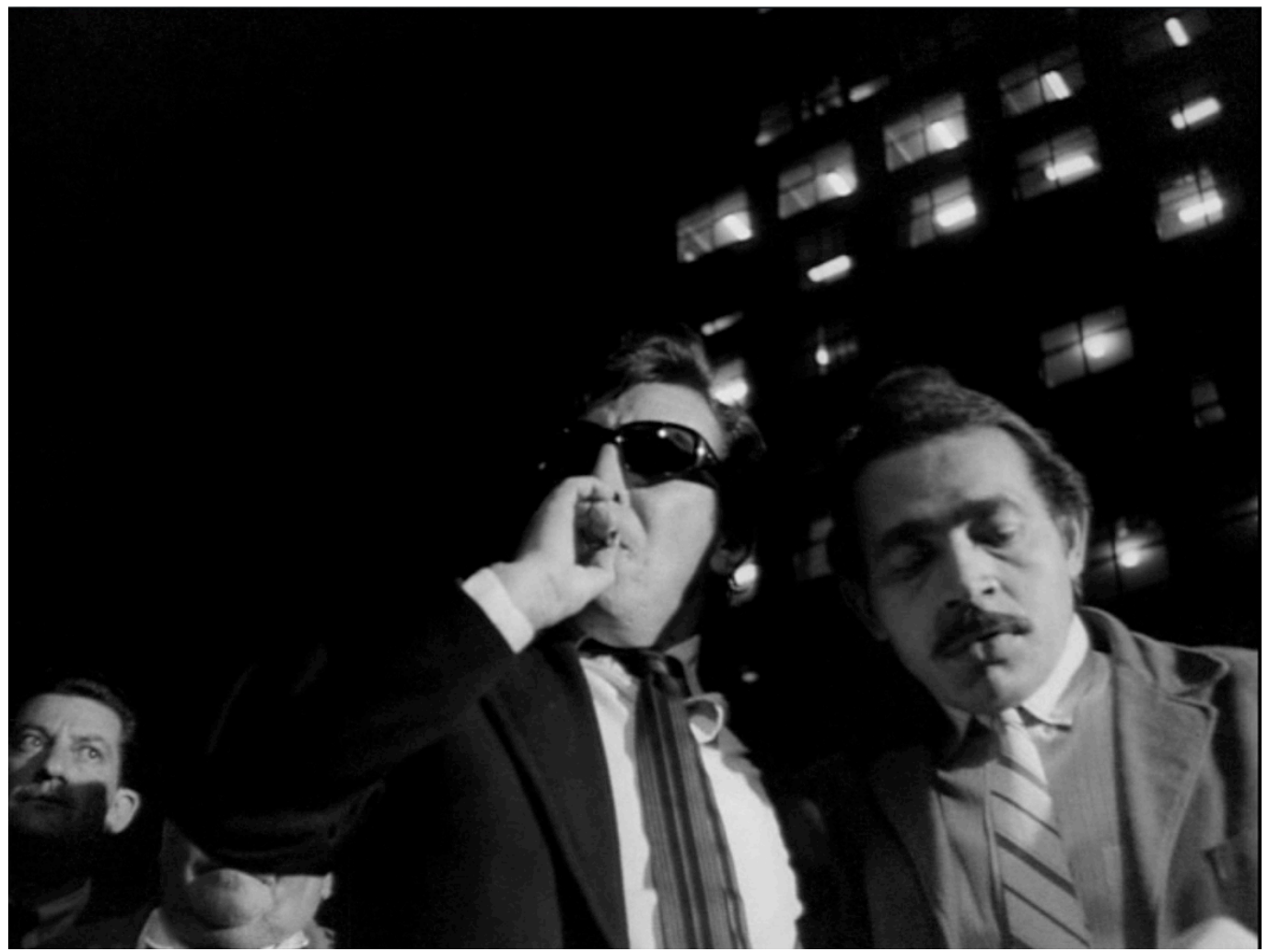

Fotograma do filme "O Bandido da Luz Vermelha" 
Figura 42 - Delegado Cabeção tira os óculos em cena noturna.

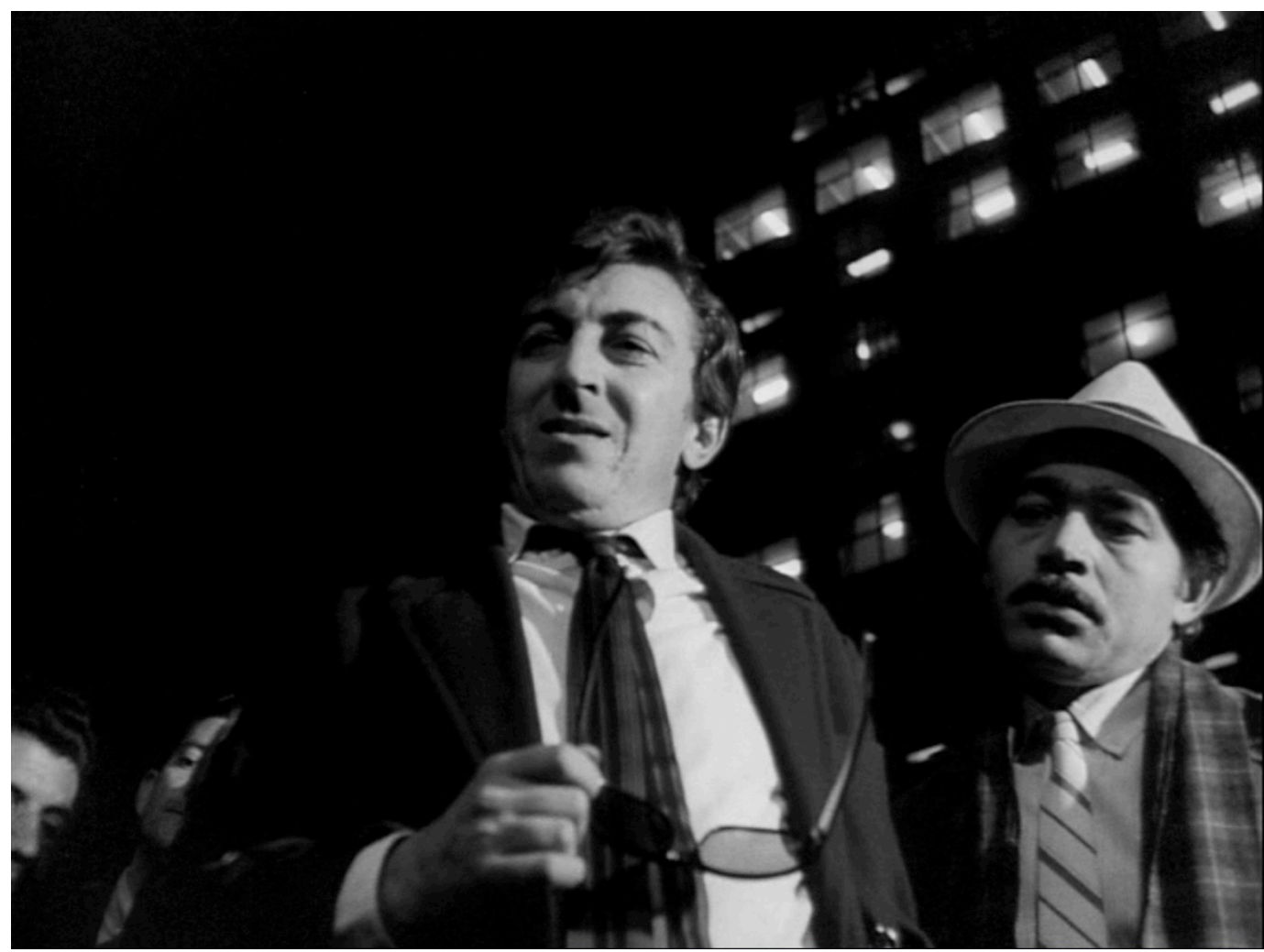

Fotograma do filme "O Bandido da Luz Vermelha"

Não se pode deixar de citar o "Anão Profeta", um dos personagens mais esquisitos do filme. É ele quem repete o refrão nonsense: "O terceiro mundo vai explodir, quem estiver de sapato não sobra... não pode sobrar!". Nesta cena é possível notar a falta de continuidade do filme, uma das características do cinema de Rogério Sganzerla. Quando ele diz: "O terceiro mundo vai explodir...", veste uma calça de alfaiataria em meio tom, camisa pólo bem clara, paletó abotoado, um pouco mais escuro que a calça, e um chapéu panamá claro. Está diante de um muro com trepadeiras (figura 43).

Na segunda parte da frase "... quem estiver de sapato não sobra... não pode sobrar!", está com o mesmo figurino, só que o paletó está desabotoado e sem chapéu, diante de uma grade, como pode ser conferido na figura 44. Neste momento, é possível reconhecer que a pólo clara possui uma textura, tecido canelado. Depois disso, as cenas são intercaladas com o personagem usando ou não o chapéu. O anão possui uma mancha no rosto, o que torna sua figura mais bizarra. 
Figura 43 - "Anão Profeta" repetindo o refrão nonsense diante do muro.

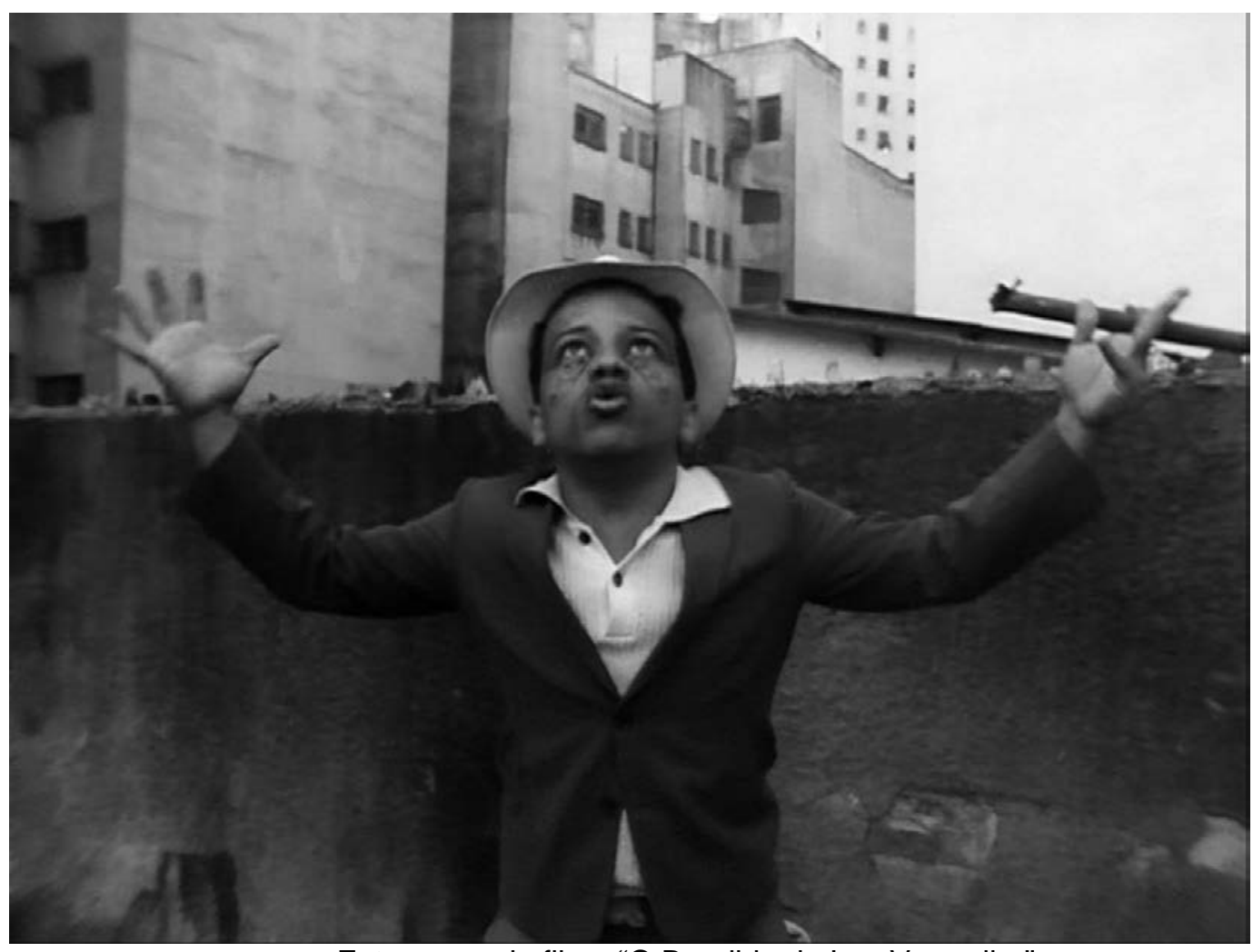

Fotograma do filme "O Bandido da Luz Vermelha"

Figura 44 - "Anão Profeta" repetindo a segunda parte do refrão nonsense diante de uma grade.

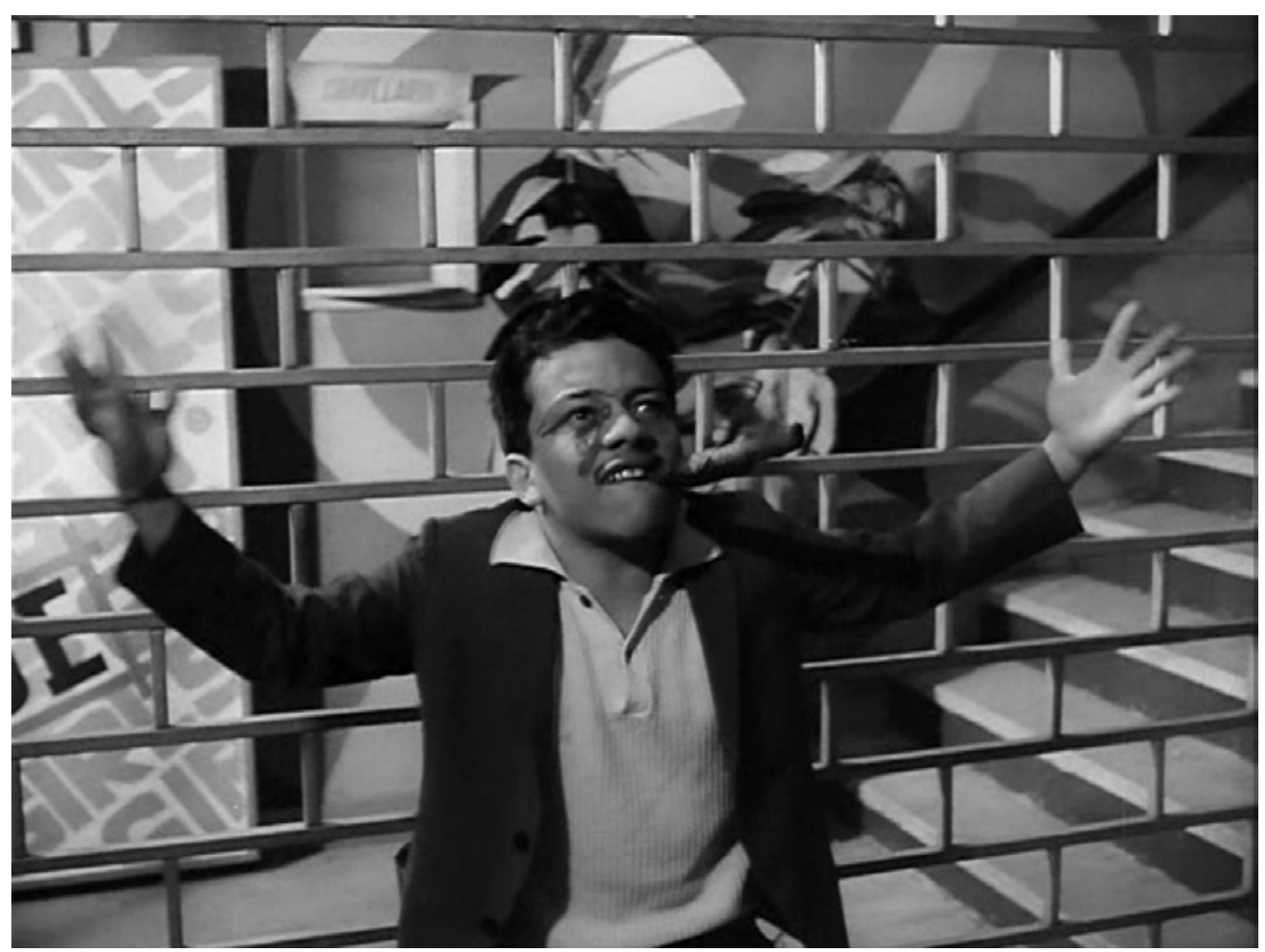

Fotograma do filme "O Bandido da Luz Vermelha" 
Diversas cenas urbanas mostram a passagem de tempo e pela primeira vez Janete Jane, a amante do Bandido, aparece num frame ao lado de seu cafetão Lucho Gatica, interpretado por Roberto Luna, como pode ser visto na figura 45. A personagem usa uma minissaia escura, fotografada como preta, levemente evasê, com matelassê, provavelmente em cetim, camiseta clara manga curta transparente, cinto de argolas com ligeira assimetria e uma bolsinha clara. Tem uma pulseira fininha no braço esquerdo. Em contraste à sua figura, o cafetão está todo em tom escuro, calça, camisa, foulard e óculos escuros. Mais uma vez, o acessório mascara outro personagem da trama. A camisa é de um tecido pesado e a calça larga possui pregas, não revelando a silhueta do ator. Este figurino sugere movimento de ascender. Nesta cena o espectador ainda não conhece estes dois personagens.

Em todo o filme, observam-se dois momentos onde o Bandido dá uma gargalhada, quando ele rouba um carro (figura 46) e na cena que antecede o seu suicídio. Com exceção destas cenas, está quase sempre em estado de tensão ou depressão, com uma visão negativa de si mesmo. Após roubar um carro em um estacionamento, o Bandido segue dirigindo e gargalhando. Usa uma blusa gola alta bem clara combinada com um blazer claro, porém mais escuro que a blusa, e uma calça em médio tom. O blazer tem um tecido leve, que demonstra movimento no instante que ele salta para dentro do carro conversível que irá roubar.

Figura 45 - Janete Jane aparece pela primeira vez ao lado de seu cafetão.

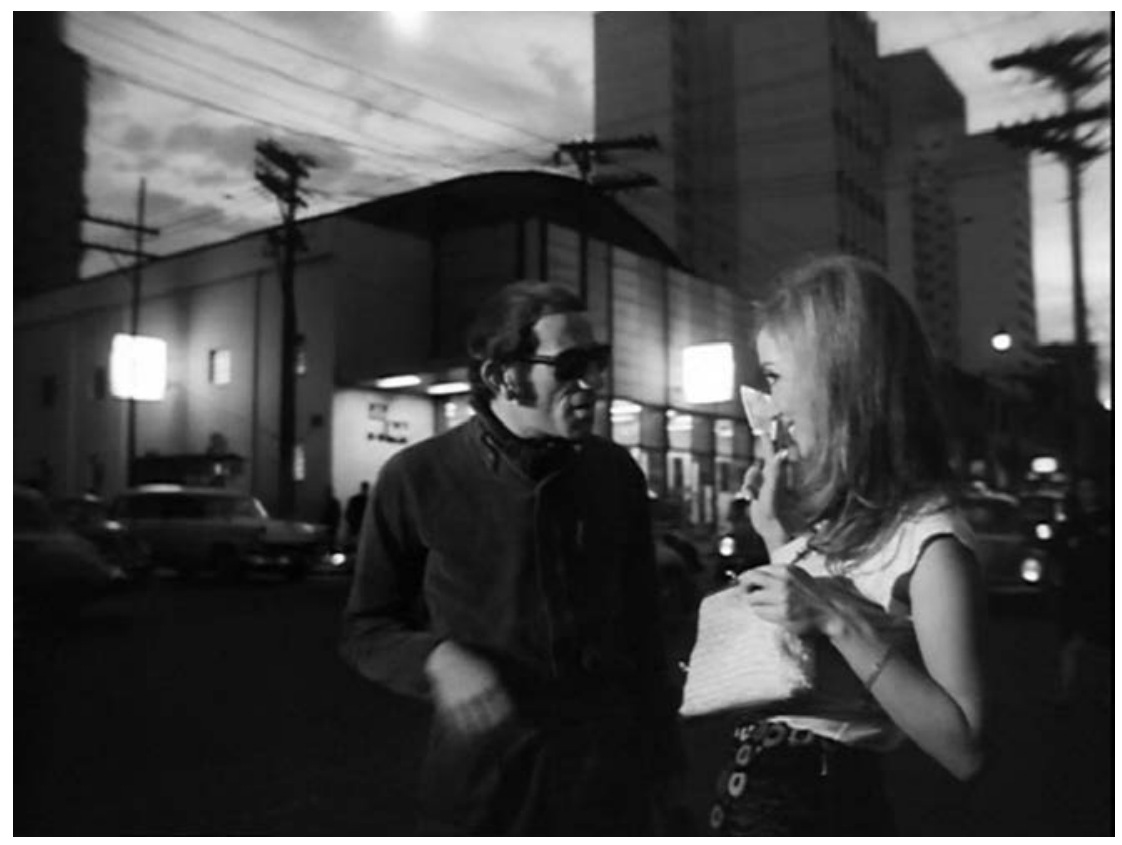

Fotogramas do filme "O Bandido da Luz Vermelha" 
O figurino é constantemente alterado dentro de uma mesma cena. Numa cena de assalto, o Bandido está com o blazer claro com microtextura, provavelmente a mesma peça usada quando ele dá tiros pelas ruas, sobre uma malha de gola alta bem clara canelada, calça estreita com a boca afunilada, aparentemente em veludo, com um lenço cobrindo o rosto. De repente ele aparece com um chapéu de plumas roubado da vítima (figura 47). Está sentado diante do armário da vítima e abaixa o lenço que Ihe cobria o rosto para comer uma omelete na frigideira. A escolha do acessório feminino para esta cena destoa do restante do figurino do personagem e contrapõe-se à atitude de um homem viril e que causa horror às vítimas. Os acessórios, como mencionado anteriormente, possuem forte simbologia e significados para a representação da sexualidade. Nesta sequência, pode-se comprovar que o blazer do personagem está curto nas mangas, indicando ser de outra pessoa. É também a primeira vez que vemos os pés do Bandido, calçando meias e botas escuras de cano curto. Este tipo de calçado dá firmeza e peso ao andar do ator.

Figura 46 - O Bandido gargalha ao roubar um carro.

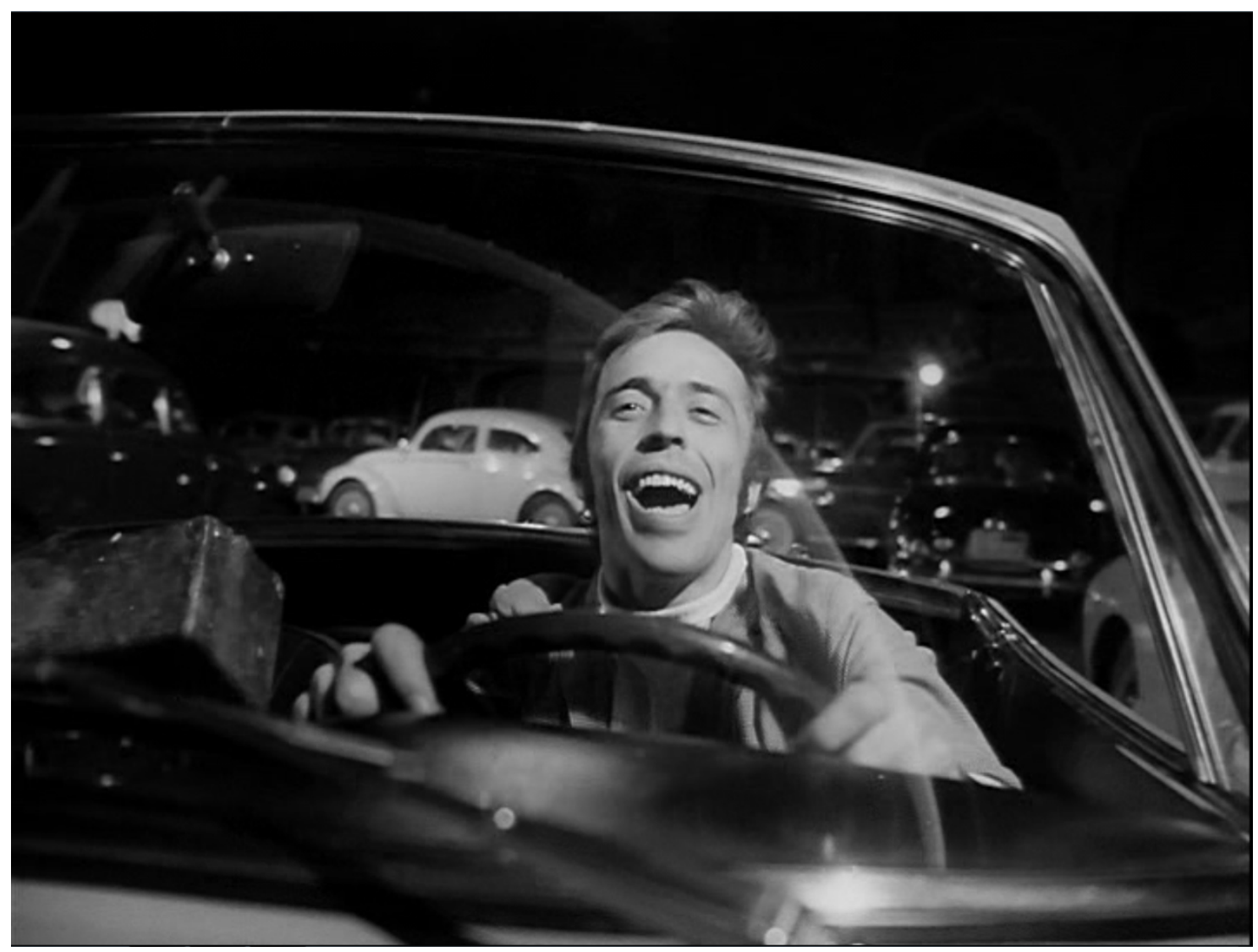

Fotograma do filme "O Bandido da Luz Vermelha" 
Para Bernadet (1990), o ator Paulo Villaça possui uma brilhante e estilisticamente homogênea interpretação, cujas entonações, olhares, gestos mantêm uma unidade do início ao fim do filme, em oposição à eclética dispersão verbal escrita (luminoso, jornais, revistas, cartas anônimas, grafite) ou oral (os locutores off, o bandido off ou in) apresentada no filme. O corpo do ator, seu gestual e expressão, têm unidade, mas não necessariamente o personagem interpretado por ele. Bernadet aponta uma unidade que manifesta a multiplicidade, a ausência de unidade perceptível no figurino do personagem.

\begin{abstract}
Villaça usa uma quantidade bastante grande de figurinos. Arrisco uns 20, talvez mais. As peças são simples e relativamente poucas: camisas, calças, alguns acessórios como chapéu, bigode, óculos, que sendo combinados, acabam compondo uma série de figuras, o que coaduna perfeitamente com a multiplicidade de suas ex-profissões, nacionalidades e nomes falsos. Raramente o bandido repete o mesmo figurino, e se o fizer, será em sequências distantes uma das outras, sem que se note entre elas um vínculo narrativo (BERNADET, 1990, p. 159).
\end{abstract}

Figura 47 - O Bandido vestindo um chapéu feminino diante do armário de uma de suas vítimas.

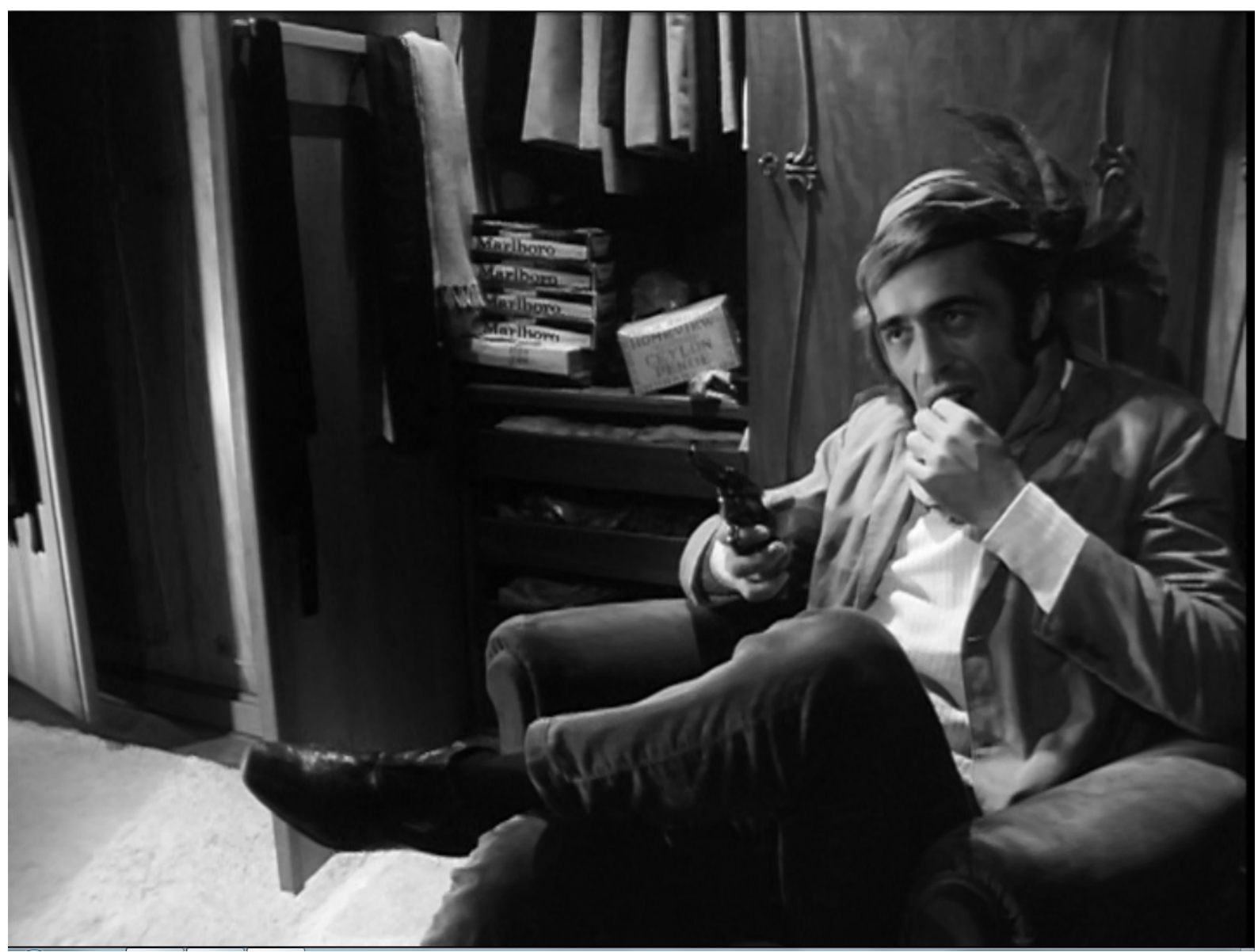

Fotograma do filme "O Bandido da Luz Vermelha" 
No processo de caracterização de um personagem, o figurino é o instrumento que mais comumente o identifica, pois consegue definir sua classe social, idade, sexo, estação do ano, às vezes, nacionalidade, localização geográfica, religião, e até costumes, preferências pessoais, traços de caráter e maneiras de pensar (GUERRA; LEITE, 2001). Por isso, o figurino comprova a falta de identidade do Bandido com os múltiplos trajes e disfarces exibidos por ele.

Em alguns momentos o Bandido troca de roupa durante a sequência. Muitas vezes diante dos armários de suas vítimas. Importante pontuar a riqueza dos detalhes num plano fechado, quando o protagonista se arruma à frente de um guarda-roupa, como se observa na figura 48. As abotoaduras têm o brilho necessário para pontuar a vaidade do personagem. O blazer escuro de veludo cotelê traz textura e peso ao enquadramento, que se opõe à peça xadrez, Príncipe de Gales, ao fundo no canto esquerdo do quadro. A camisa lisa bem clara de tecido leve vestida por cima do suéter canelado, como é possível ver no punho do ator, contrasta com o blazer.

Figura 48 - Detalhes do figurino do Bandido.

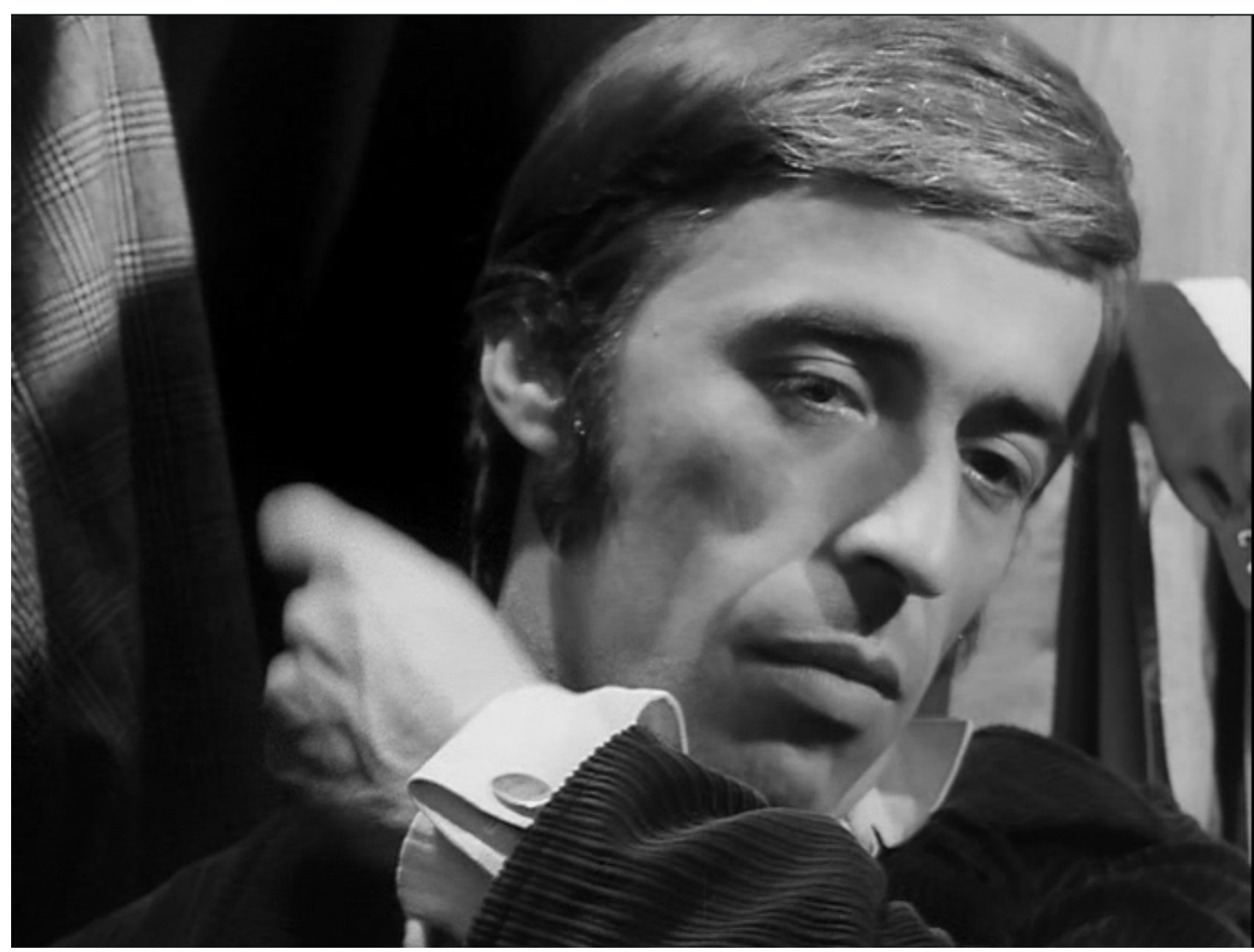

Fotograma do filme "O Bandido da Luz Vermelha" 
Delegado Cabeção usa sempre camisa clara, gravata escura e casaco em lã também escuro. Em algumas cenas é possível visualizar um anel de dedinho usado na mão direita. Após um dos assaltos do Bandido, durante a investigação na casa de uma das vítimas, ele aparece com camisa clara, gravata de crochê escura e carregando o casaco no braço esquerdo. Neste momento, pode-se ver o coldre de ombro com a arma aparente, acessório bastante comum nos filmes policiais americanos. Na mão direita, segura os óculos escuros, acessório presente na sua caracterização, vide figura 49.

Figura 49 - Delegado Cabeção revela o uso de coldre de ombro.

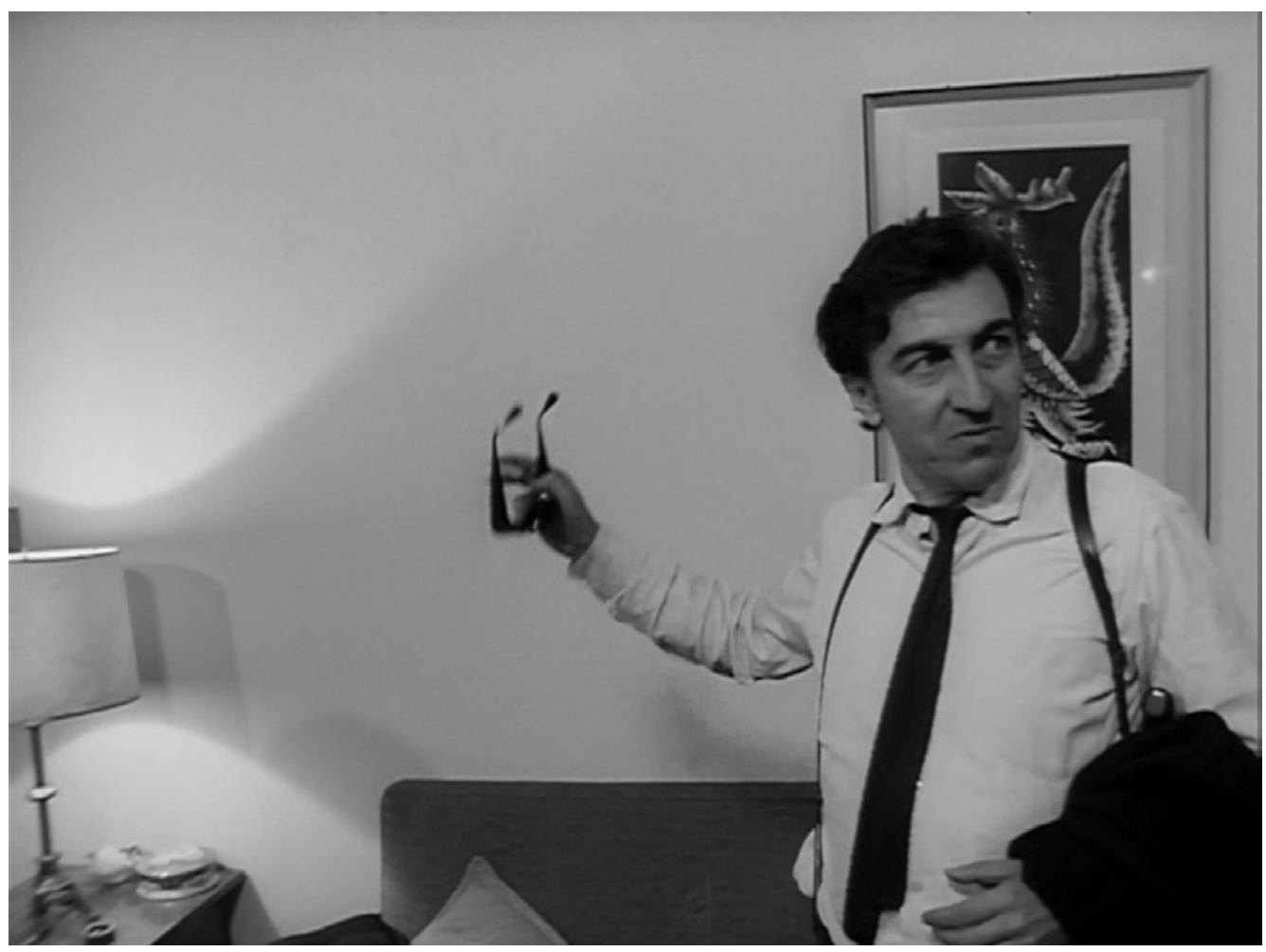

Fotograma do filme "O Bandido da Luz Vermelha"

Nos assaltos praticados pelo Bandido, sua concentração constantemente se volta para objetos que destacam a desproporção entre sua violência, sua fama e o lucro obtido. Nas horas de lazer, o Bandido se preocupa com sua aparência: é frequente a compra de roupas, o que ressalta a sua fixação pelos guarda-roupas das casas invadidas e a prática da experimentação de calças, paletós, chapéus.

Numa loja onde o Bandido experimenta roupas, elas aparecem alinhadas. Antes do personagem começar a ação, tem-se um plano onde a câmera passeia sobre vários ternos enfileirados nos cabides. Nesta cena, o Bandido veste camisa 
bicolor em tom bem claro contrastando com as mangas curtas bem escuras, em anarruga, com uma gravata estampada, visível na figura 50, calça risca de giz e cinto com listras horizontais. O figurino é destoante e torna-se mais conflitante no momento em que ele experimenta um casaco xadrez (figura 51). Não existe equilíbrio no look, que contrasta com a arrumação das peças dentro da loja.

Figura 50 - O protagonista experimenta roupas na loja.

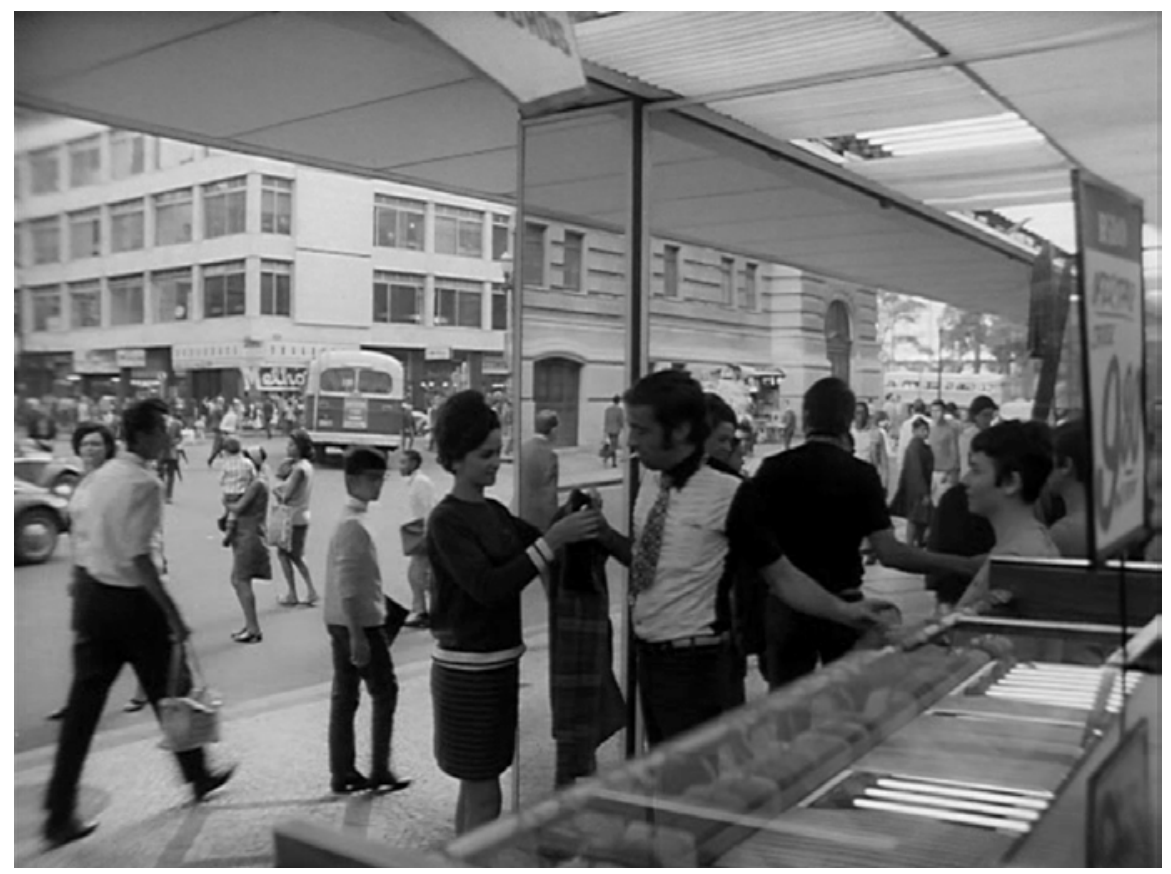

Fotograma do filme "O Bandido da Luz Vermelha"

Figura 51 - O protagonista experimenta casaco xadrez.

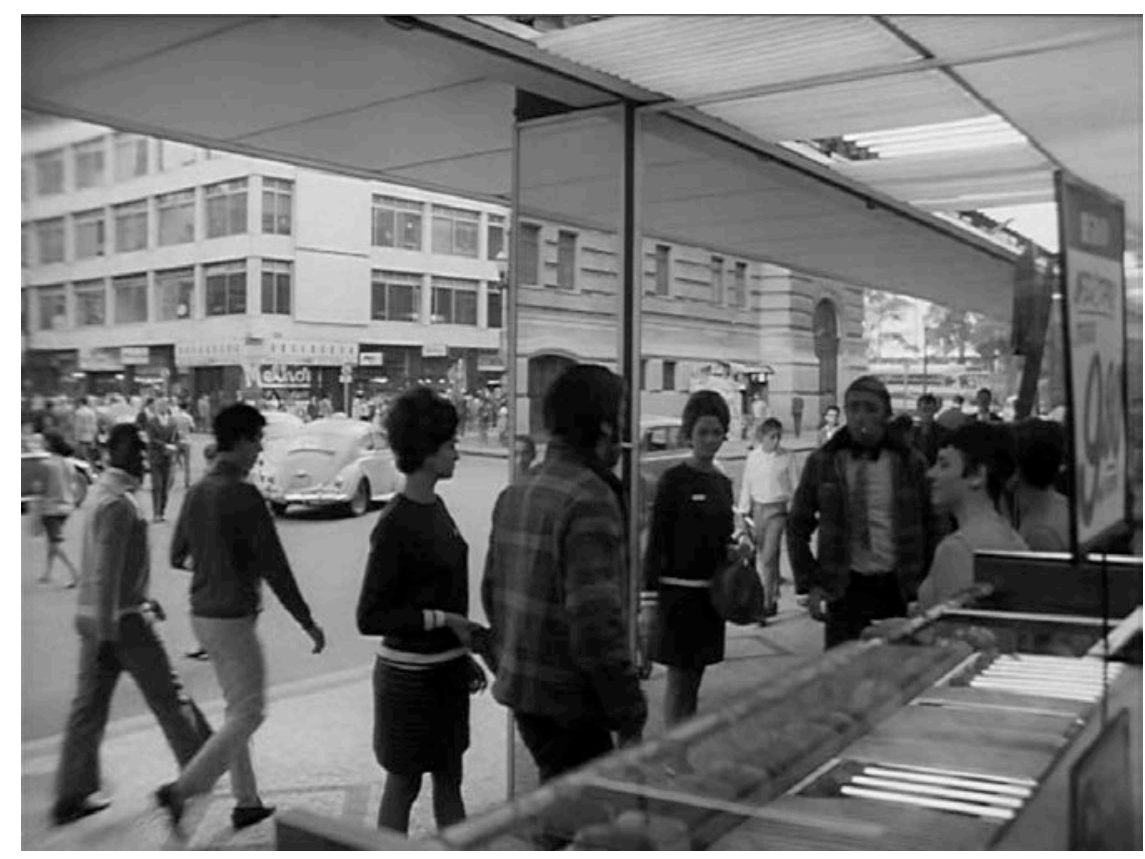

Fotograma do filme "O Bandido da Luz Vermelha" 
$\mathrm{Na}$ sequência seguinte, o protagonista se encontra com um comprador de objetos roubados em um coreto da cidade. Ele já está sem a gravata e vestido com o casaco xadrez que comprou na loja de roupas, carrega um rádio e usa fones de ouvido. O comprador é interpretado pelo cineasta Ozualdo Candeias, que faz uma ponta no filme. Veste uma camisa com um xadrez miúdo, jaqueta preta e óculos escuros, fumando uma cigarrilha (figura 52).

Figura 52 - O cineasta Ozualdo Candeias faz ponta no filme.

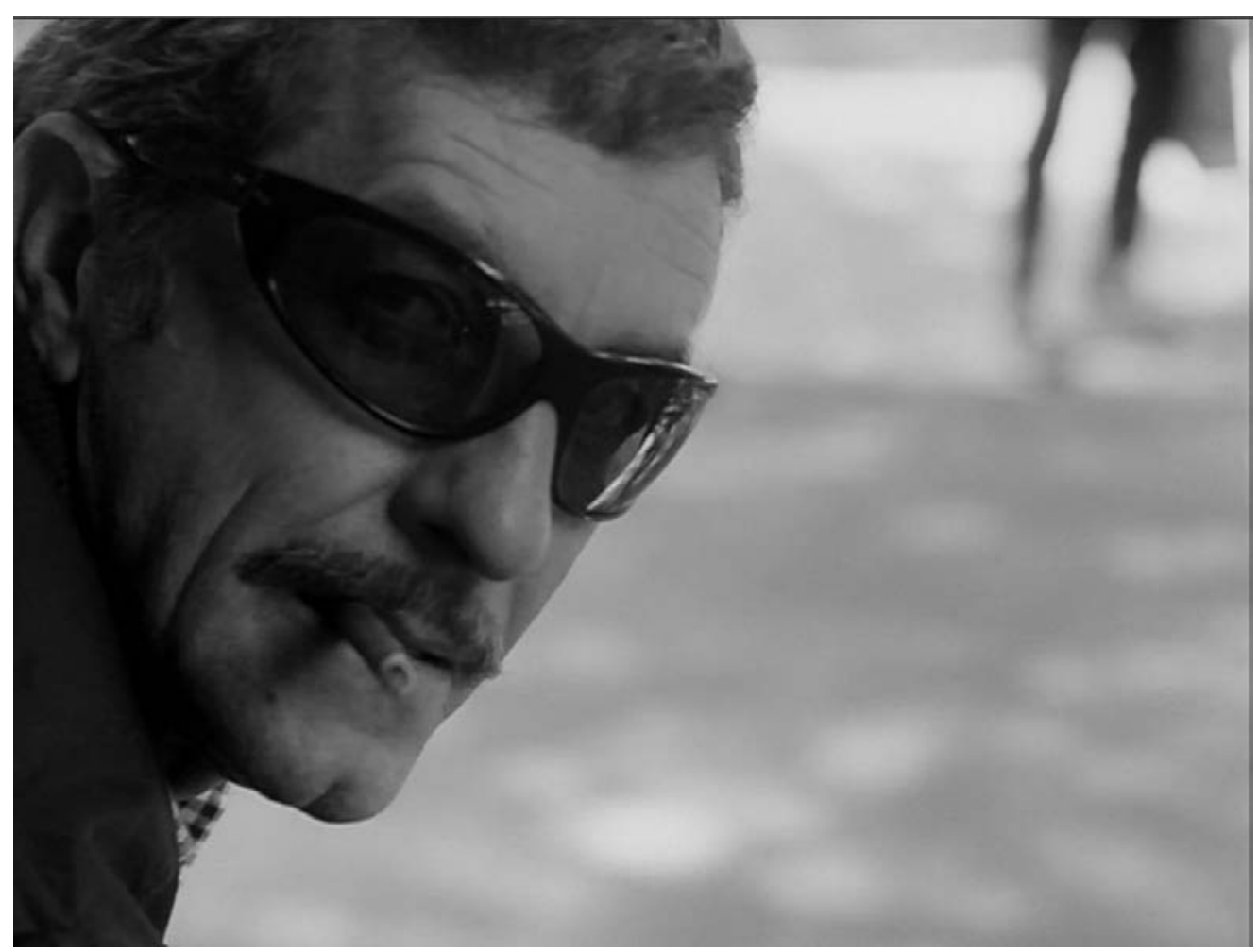

Fotograma do filme "O Bandido da Luz Vermelha"

Em diversos momentos, não existe continuidade da ação e do figurino. Em uma cena em que o protagonista escreve uma carta anônima, provavelmente em seu quarto, está com um roupão claro, espesso, volumoso e com textura, com a mão nua. Na mesma sequência, e aparece vestindo uma luva de couro sem dedos, como se observa na figura 53 e 54. O roupão felpudo e alvo transmite uma sensação de conforto, limpeza. A textura da peça compõe o quadro, que é repleto de objetos. 
Figura 53 - O Bandido escreve cartas anônimas.

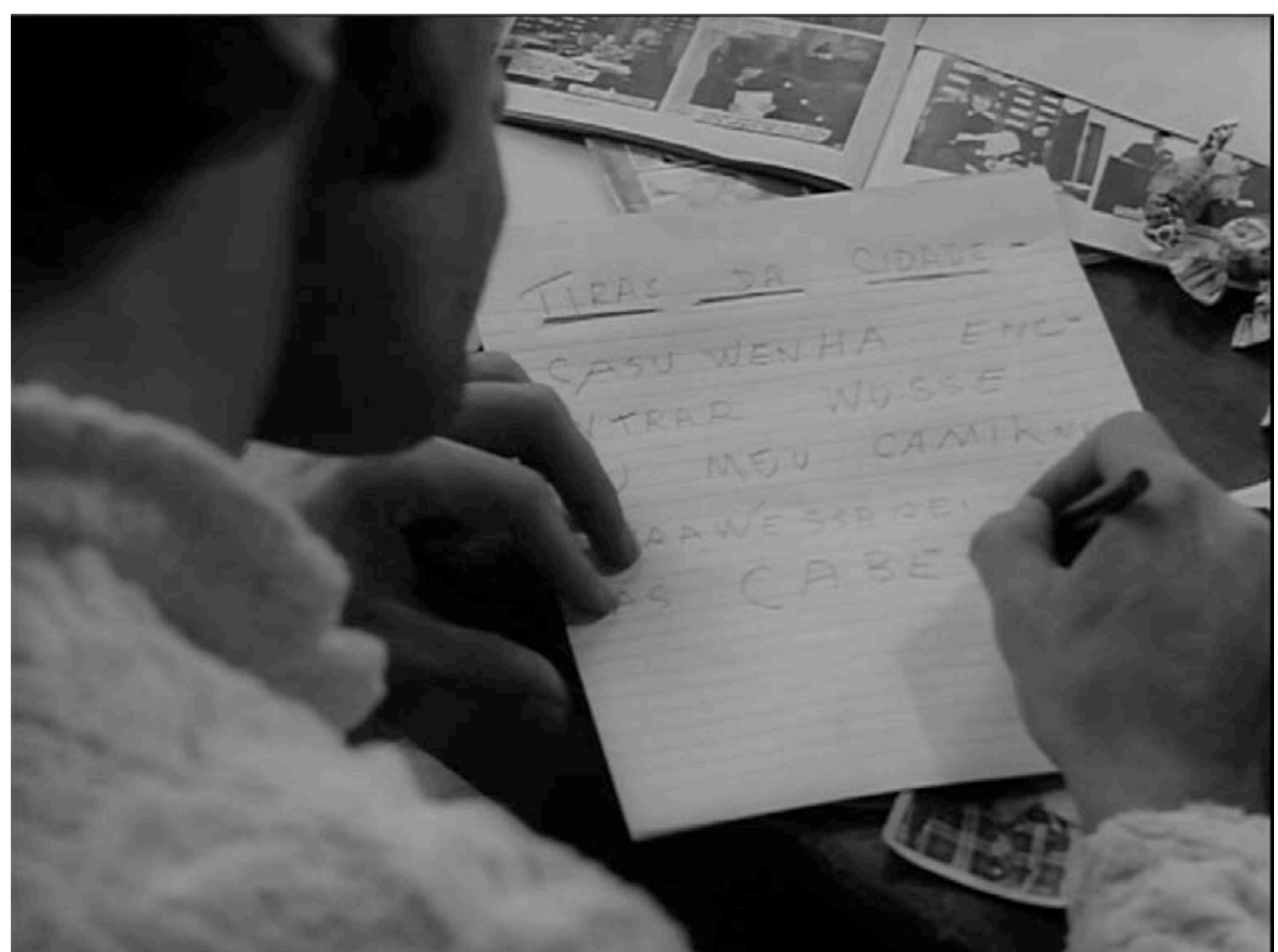

Fotograma do filme "O Bandido da Luz Vermelha"

Figura 54 - O Bandido escreve cartas anônimas com luva.

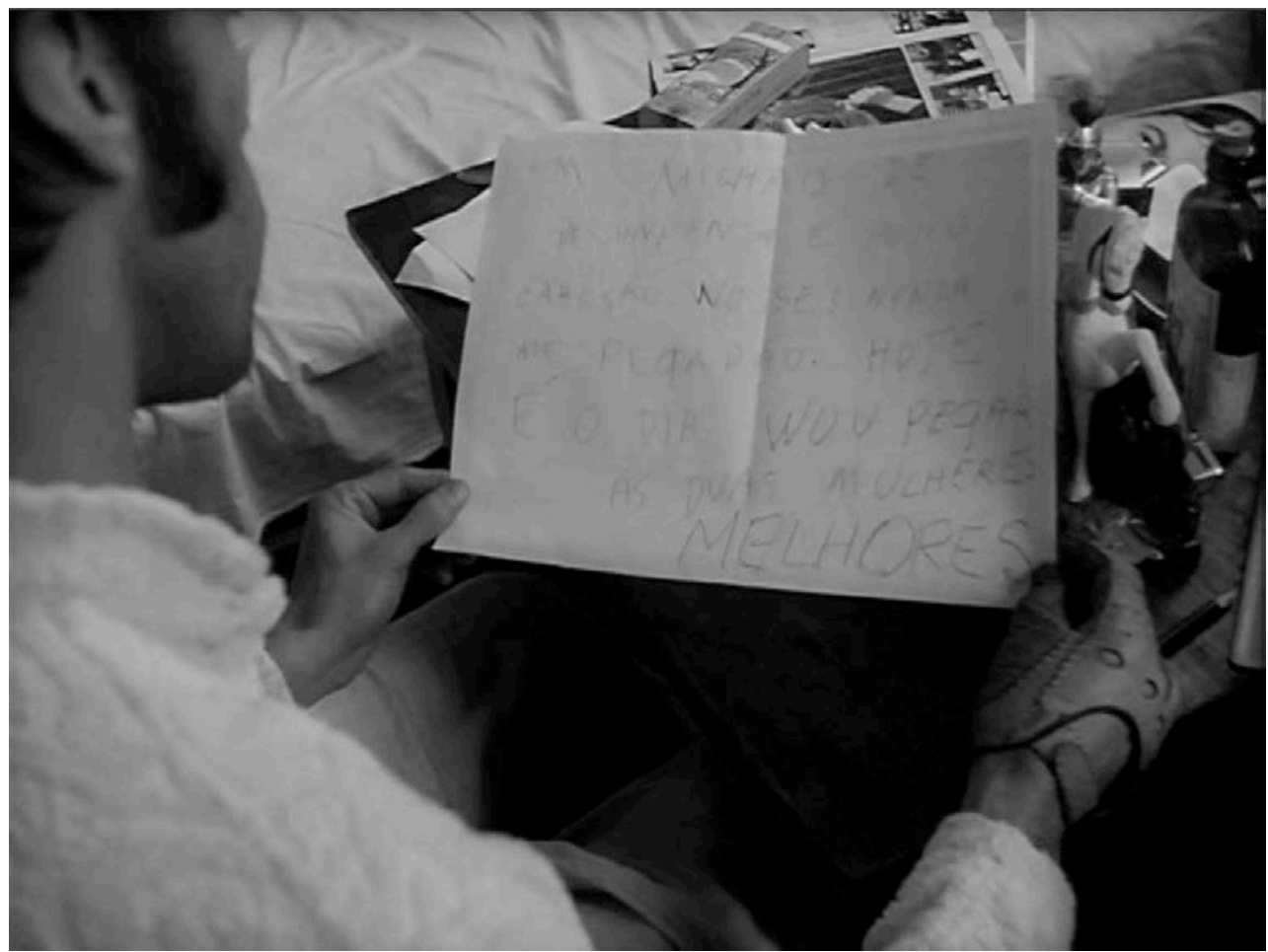

Fotograma do filme "O Bandido da Luz Vermelha" 
$\mathrm{Na}$ sequência que acontece na cozinha onde o Bandido beija uma de suas vítimas, o personagem experimenta vários óculos escuros que estão sobre uma mesa repleta de objetos e alimentos, misturados com alguns produtos de limpeza, sabão em pó e desinfetante, imagem do consumo, da densidade kitsch dos ambientes. Ouve-se o barulho em off de um liquidificador. Em seguida, o Bandido despeja o líquido num copo, acrescenta dois ovos e outros ingredientes, e depois bebe o conteúdo. Alusão feita ao filme, que é composto de vários elementos bebidos de diversas fontes. O personagem usa um blazer xadrez Príncipe de Gales, curto nas mangas (novamente indica que não deve ser dele), combinado com camisa clara com o colarinho desabotoado e uma gravata estreita escura. O blazer tem um peso e parece ser em lã fria. A vítima ao seu lado possui todos os elementos da moda da década. Usa minissaia com meia calça trabalhada e blusa manga longa em tricot listrado, cílios postiços e delineador (figura 55). No momento em que os dois se beijam um mix de texturas preenche a tela (figura 56).

Figura 55 - O Bandido prepara uma bebida.

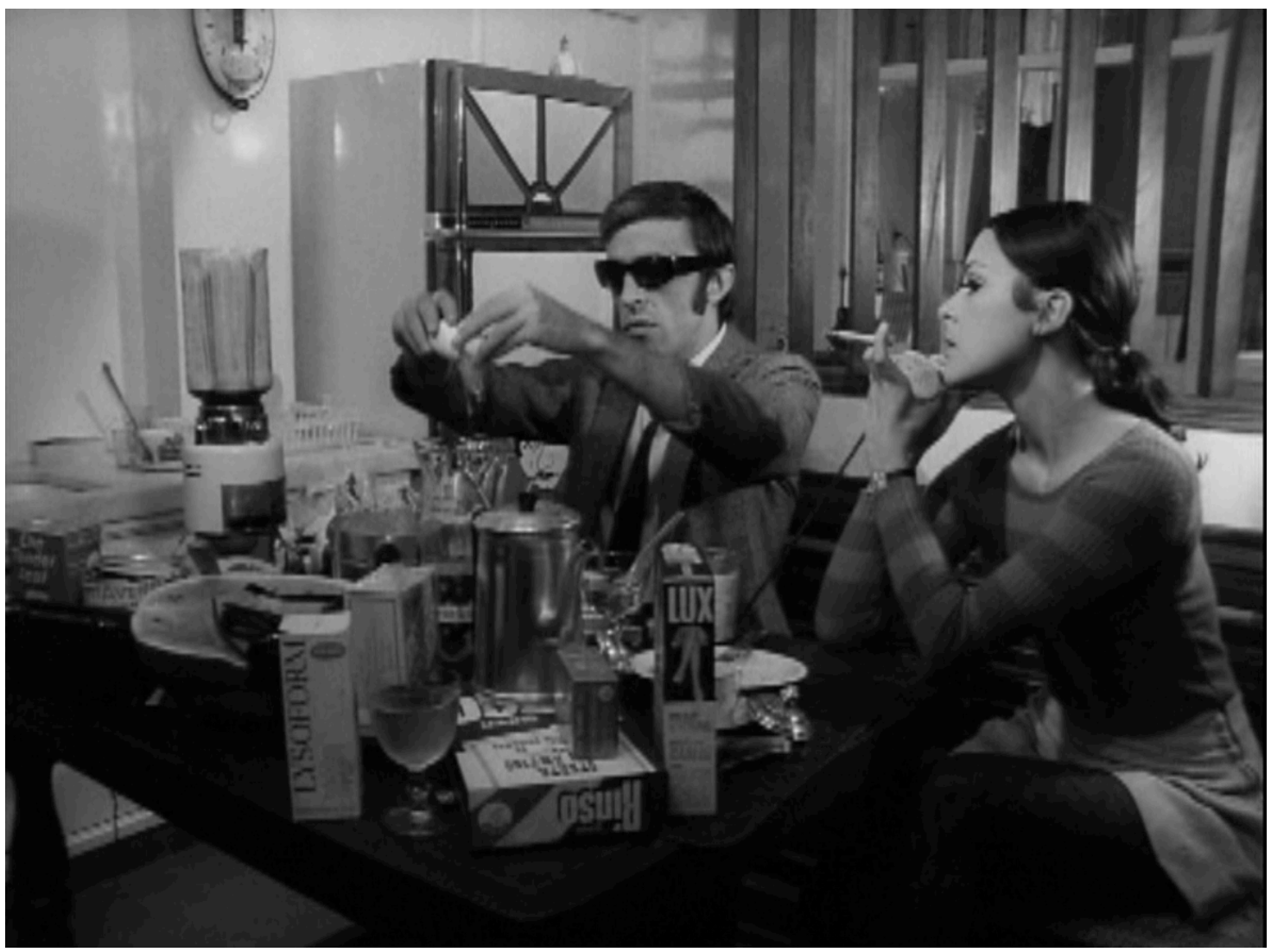

Fotograma do filme "O Bandido da Luz Vermelha" 
Figura 56 - O Bandido beija uma de suas vítimas.

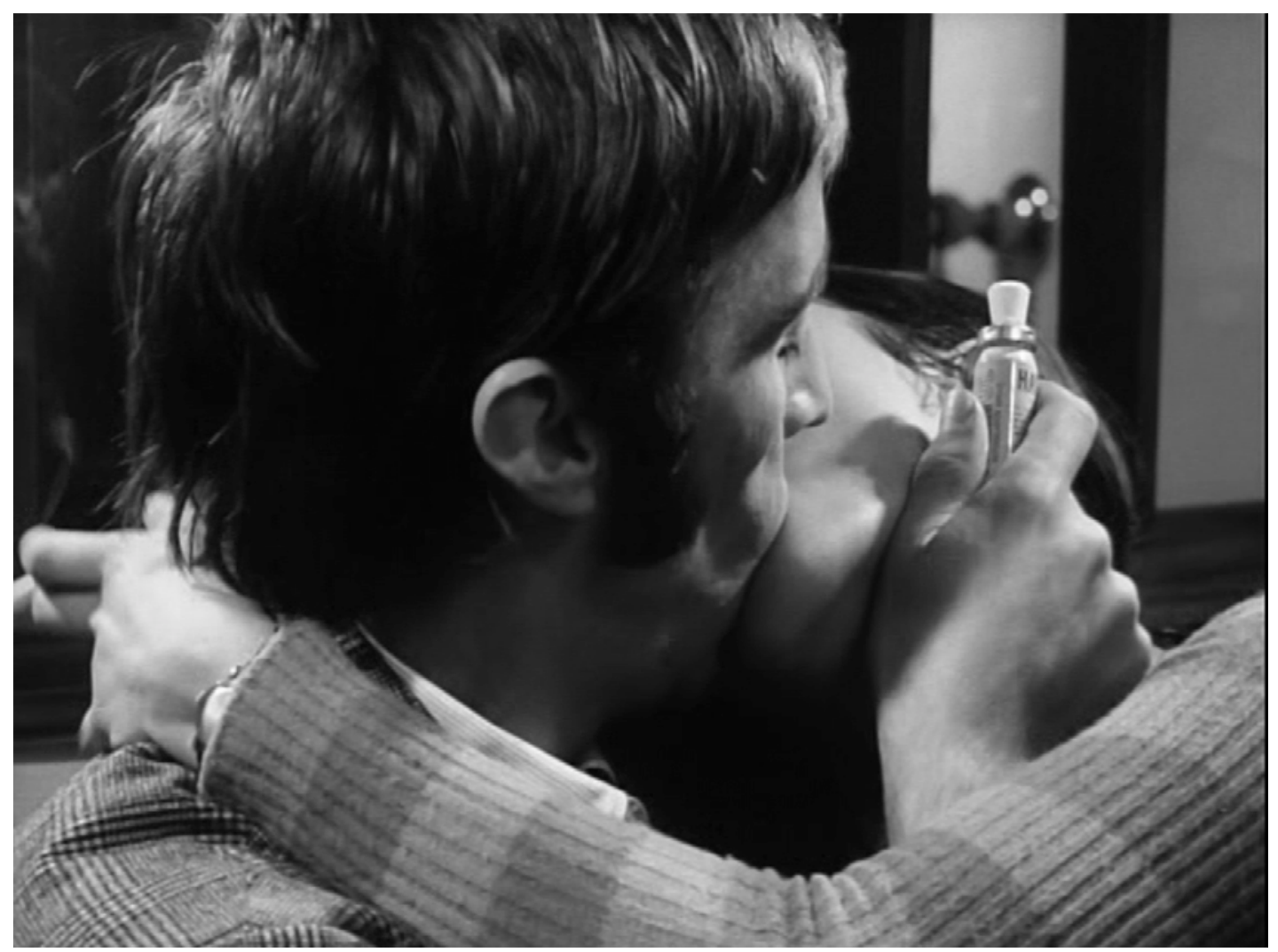

Fotograma do filme "O Bandido da Luz Vermelha"

Em um de seus assaltos, o protagonista troca de roupa diante de um armário. A cena tem início com o Bandido de cueca e camisa clara desabotoada. Ele usa um chapéu mais escuro, meias e sapatos escuros contrastando com o restante do figurino, que tem tecidos leves. Primeiramente, experimenta um paletó escuro, tira e arremessa no chão. Depois coloca uma calça em tom médio, como mostra a figura 57. Diferente do figurino do Bandido onde existe uma flutuação, as roupas dos armários são estáticas, não existe mobilidade, ficam contidas dentro de uma casa.

$O$ personagem central também usa uma blusa que parece ser feminina durante assalto a um apartamento. Carlos Ebert, em entrevista para esta pesquisa, afirmou que a camisa era masculina, "brega", comprada na Boca do Lixo (pode-se comprovar tal informação pelo abotoamento da camisa que é do lado masculino). Enquanto a vítima está no banheiro, o protagonista surge na tela grande com uma camisa de bolas brancas grandes e mangas amplas bufantes do cotovelo para baixo, combinada com uma calça riscada. Segundo Lurie (1997) as linhas curvas sugerem liberdade e descontração. Padrões em pois, sugerem o humor. Quanto maiores os círculos, mais explícito e físico é o humor. Bolas grandes sugerem farsa, 
pregar peças em tolos. A gravata listrada escura, acessório do guarda-roupa masculino, opõe-se à feminilidade da blusa e o fato de estar curta deixa o look mais esquisito, visível na figura 58. O cinto do protagonista possui uma estampa geométrica e os óculos escuros completam o visual. O figurino é desigual, não existe harmonia na sua composição, o que gera certo estranhamento ao espectador. É mais um indício da falta de identidade do personagem (EBERT, 2013).

O filme é repleto de personagens bizarros e instintivos, o melhor exemplo deles é o próprio Bandido quase que transformado num clown tragicômico. Inclusive existe uma rápida cena após um assalto, em que o personagem central está entre duas gaiolas de passarinho avaliando as joias roubadas, provavelmente no quarto dele, onde veste uma camiseta manga longa listrada, justa ao corpo, e um chapéu com abas estreitas, remetendo mais uma vez à figura clássica do clown (figura 59).

Figura 57 - O Bandido experimenta roupas.

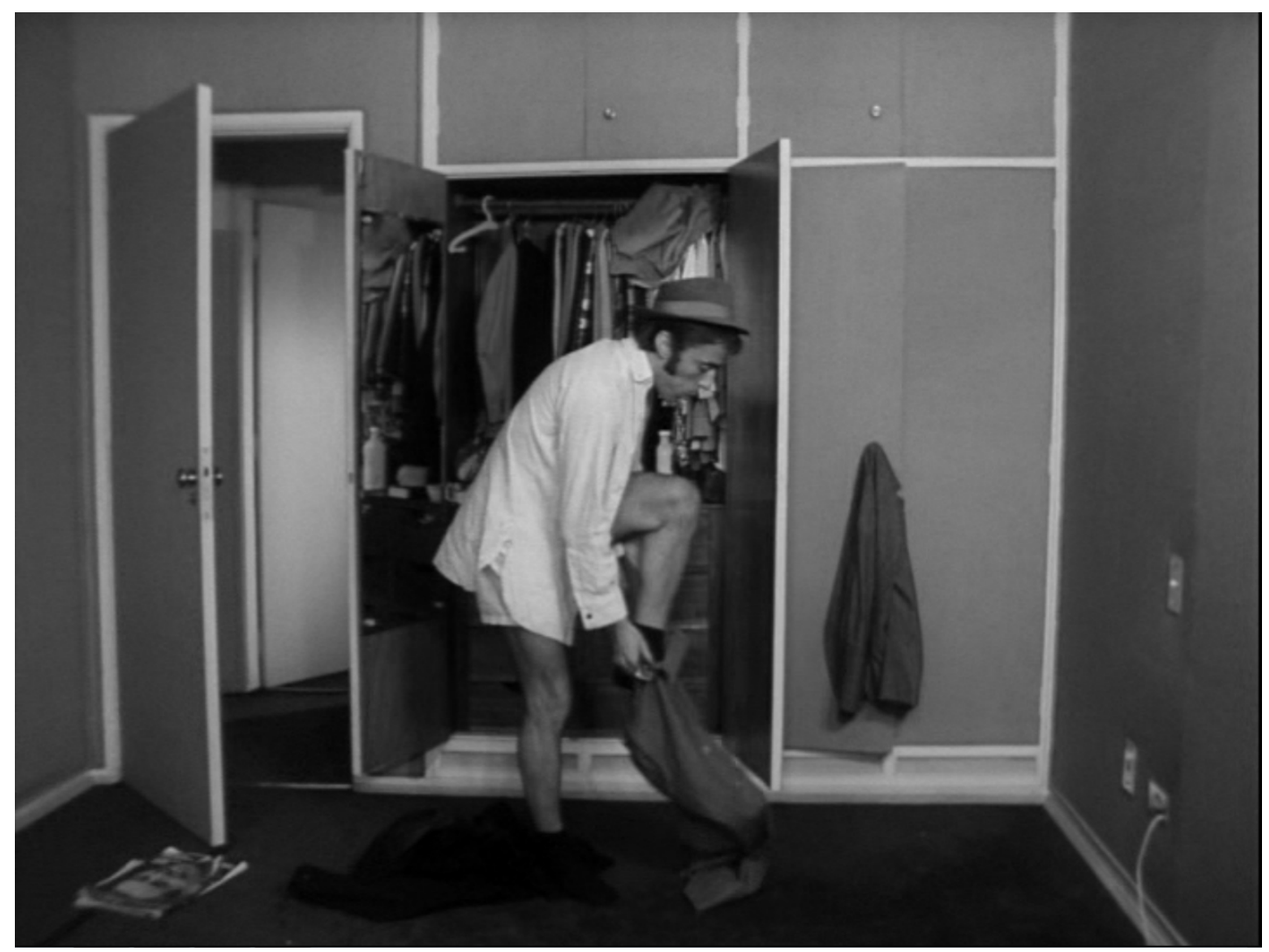

Fotograma do filme "O Bandido da Luz Vermelha" 
Figura 58 - O Bandido usa blusa de bolas.

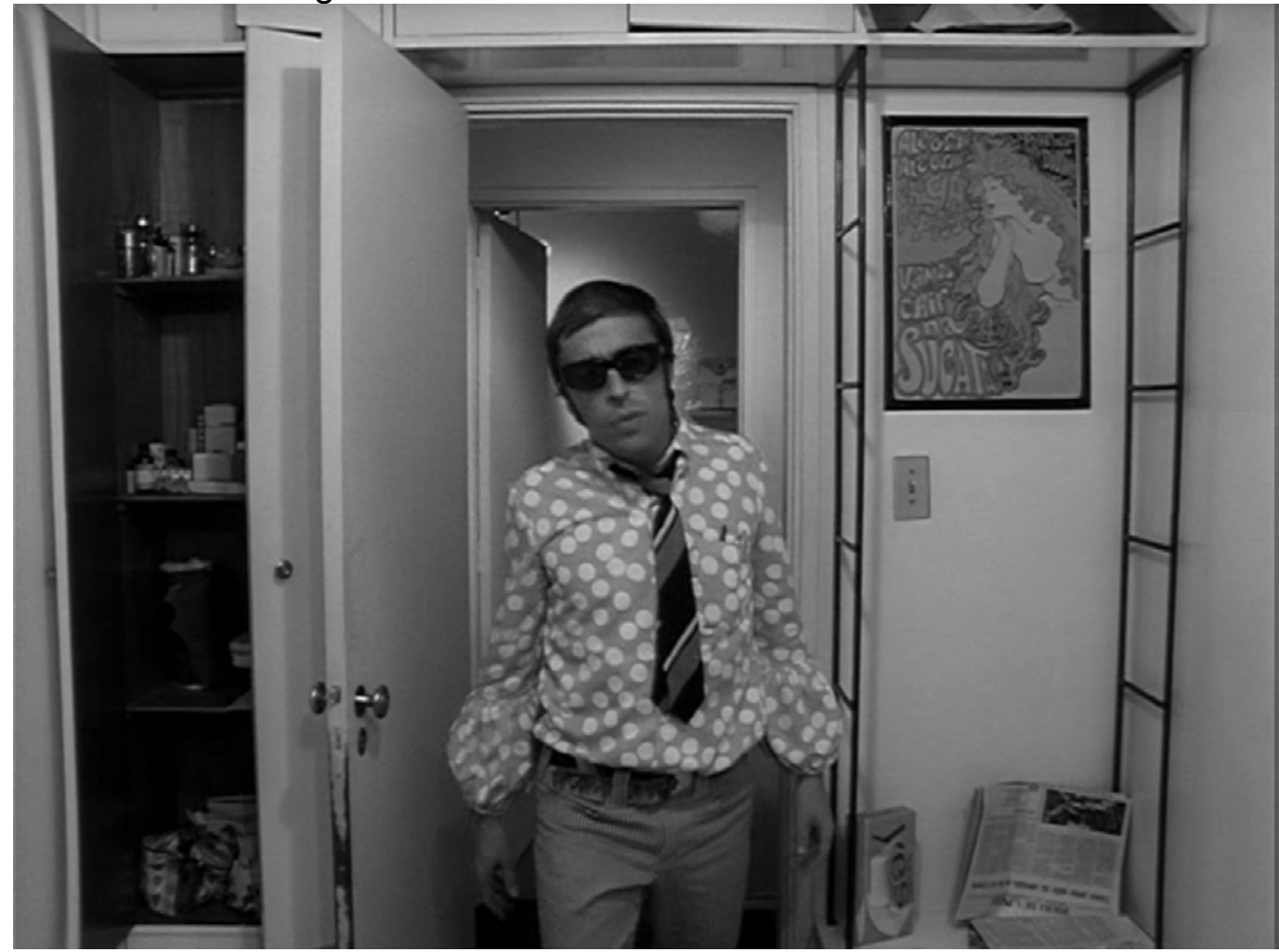

Fotograma do filme "O Bandido da Luz Vermelha"

Figura 59 - O protagonista como clown tragicômico.

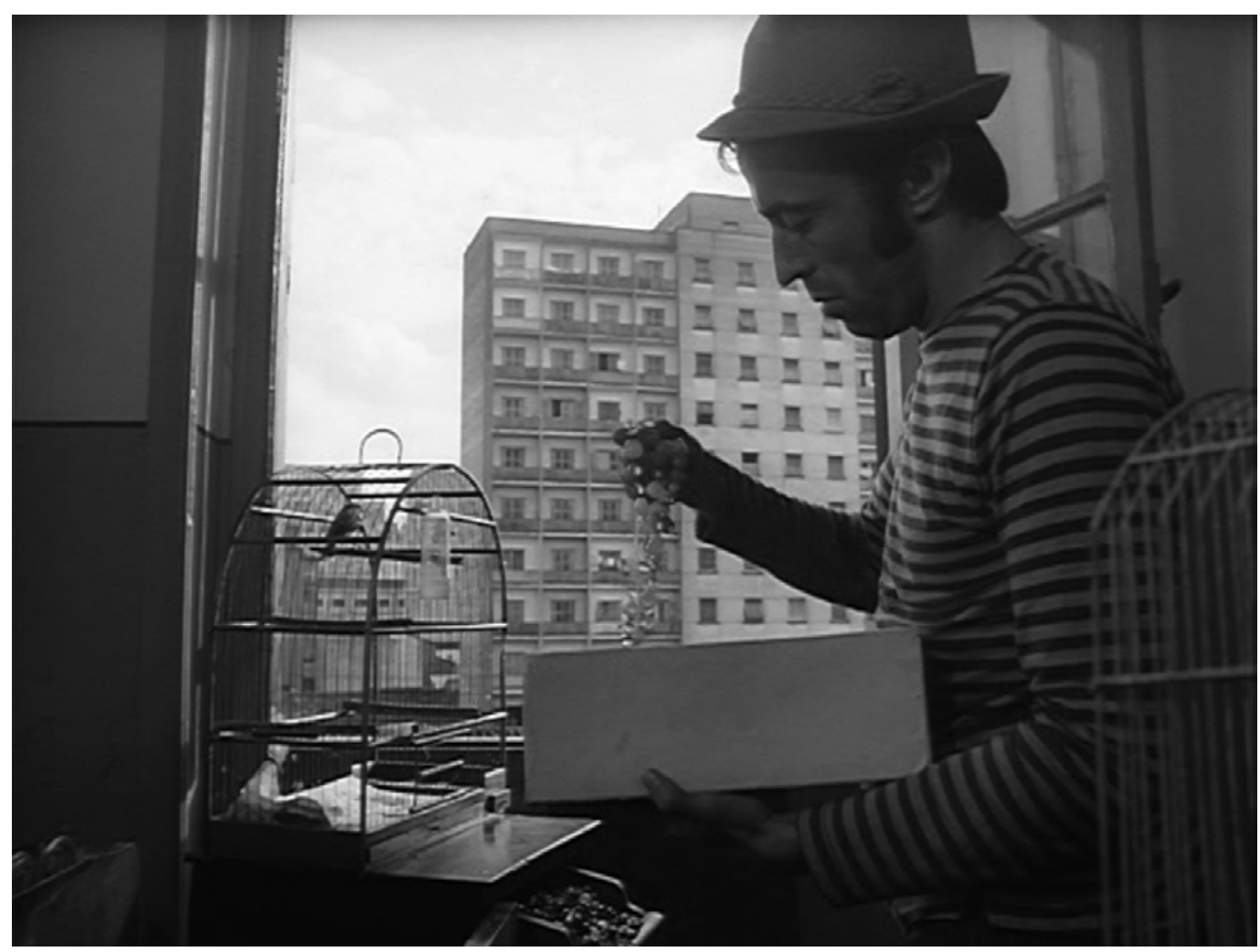

Fotograma do filme "O Bandido da Luz Vermelha" 
O Bandido tem fascínio por malas e as carrega em muitas ações, como se fossem armários portáteis. As malas apresentam a mesma desordem do armário do quarto do Bandido, como será apresentado posteriormente, mas isso só é visível quando mala está aberta, pois quando está fechada toda a bagunça fica escondida, como se observa na figura 60.

Figura 60 - O Bandido carrega uma de suas malas.

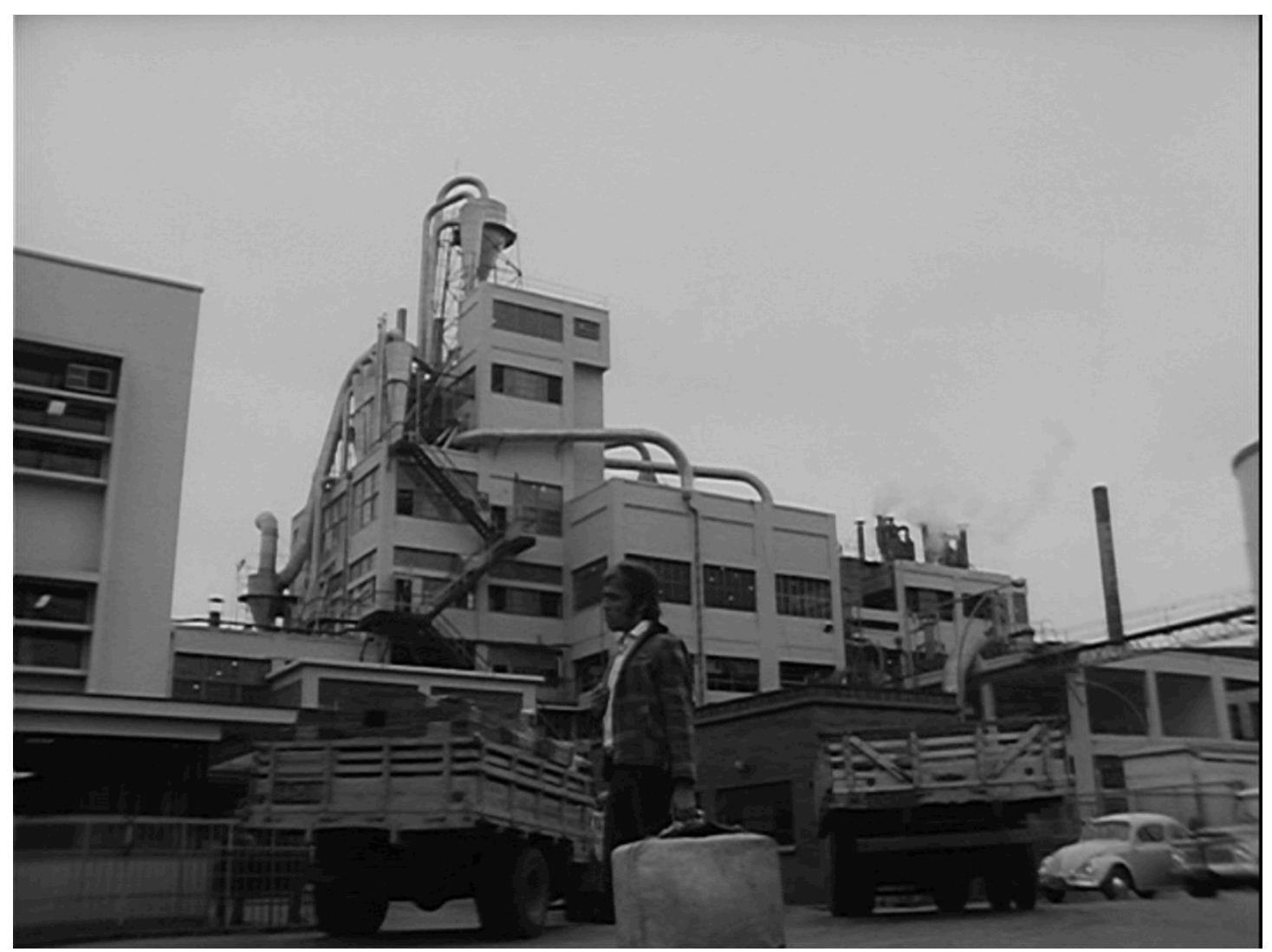

Fotograma do filme "O Bandido da Luz Vermelha"

Às vezes, é a própria peça de roupa do figurino que gera uma flutuação e impressão da falta de continuidade na narrativa. Em mais de uma cena, o Bandido veste uma camisa que tem as costas, as mangas e o colarinho escuros, mas a frente é clara. Assim, a própria movimentação do ator deixa a camisa clara ou escura. Na sequência onde ele pratica tiro ao alvo em um parque de diversões, ao lado de um garotinho que veste uma camiseta listrada, vemos em primeiro plano a calça com estampa de cobra do Bandido e, em seguida, uma camisa escura; mas quando ele vira de frente, percebe-se que a camisa possui a frente clara com mangas, costas e colarinho escuros: é bicolor, como mostra a figura 61 . O figurino é 
leve, porém sem combinação. A calça estampada não casa com a camisa, que ainda possui uma textura na parte da frente, tecido anarruga. O figurino é confuso e, mais uma vez, sublinha a falta de personalidade do herói (anti-herói).

Figura 61 - A camisa bicolor do Bandido.

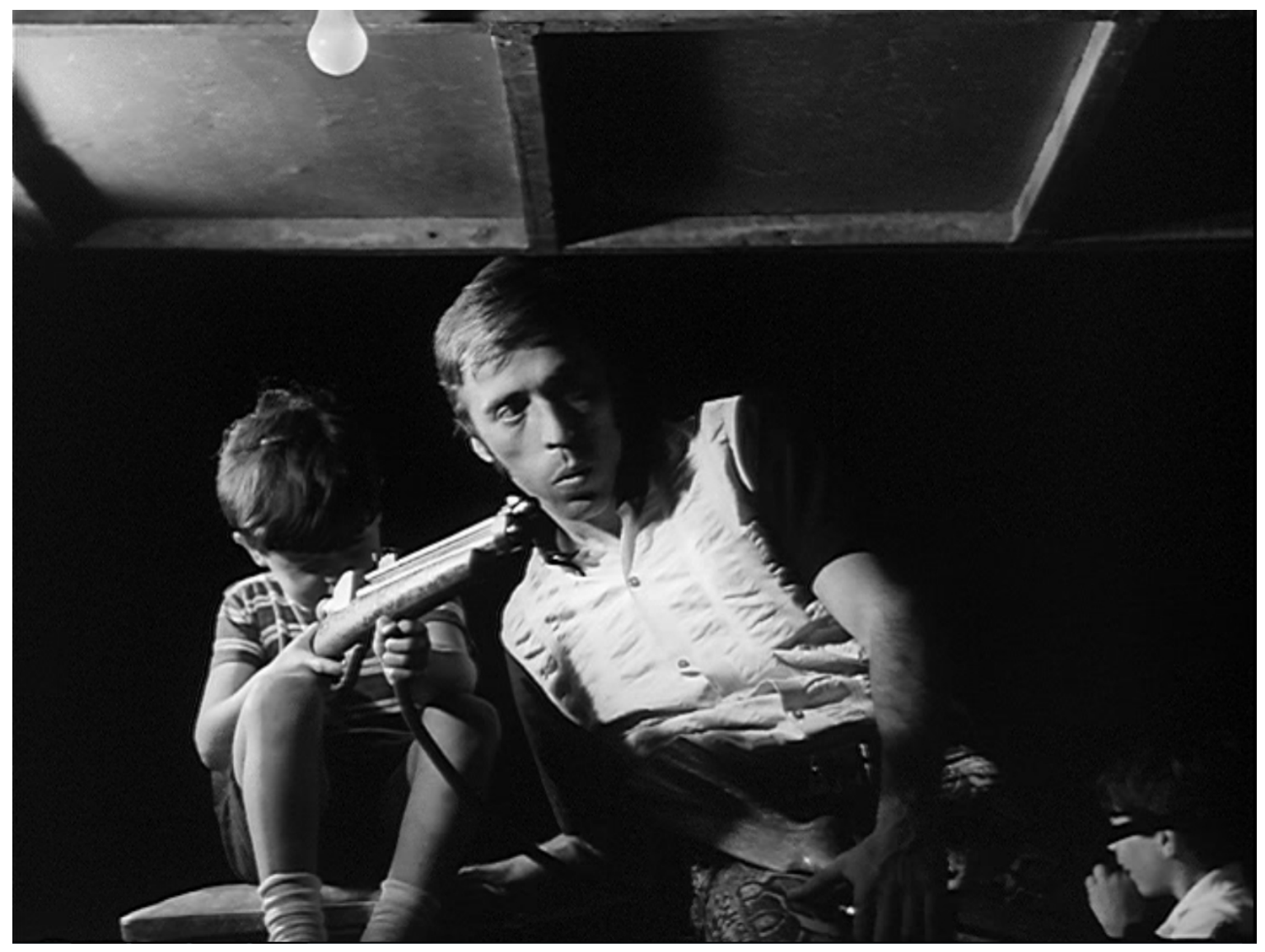

Fotograma do filme "O Bandido da Luz Vermelha"

Além da atração por malas, os armários também seduzem o Bandido. No interior do que se supõe ser seu quarto, observa-se um guarda-roupa. Logo após ele acordar, com pijama claro e vestindo meias escuras, tira um pé de meia e veste os chinelos. (figura 62) Neste momento o figurino deixa de ser simétrico, então o Bandido dirige-se ao armário, mancando, reforçando a dissimetria. Ele pega uma toalha, deixando cair no chão algumas coisas, que joga de volta no armário com certa irritação. A câmera está alta é não se pode ver o interior do guarda-roupa, mas tudo parece bastante bagunçado, diferente dos outros guarda-roupas das casas que assalta, onde as roupas estão organizadas, alinhadas e penduradas em cabides (figura 63). O ponto de vista absoluto vem sempre de cima e, segundo Sganzerla (2001), o cinema que vê do alto parece imitação do olhar divino. 
Figura 62 - O quarto do protagonista.

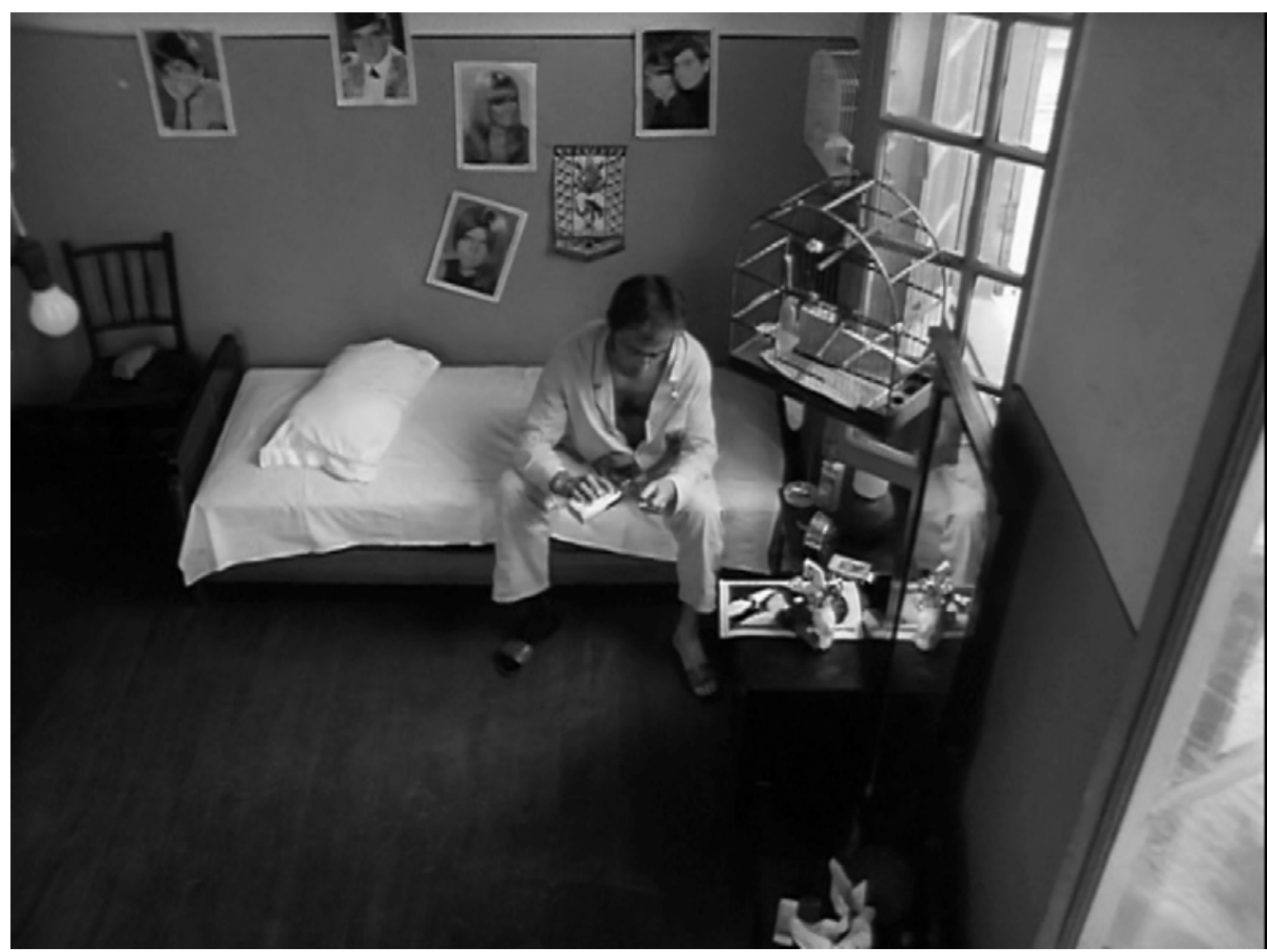

Fotograma do filme "O Bandido da Luz Vermelha"

Figura 63 - O personagem central diante de seu armário.

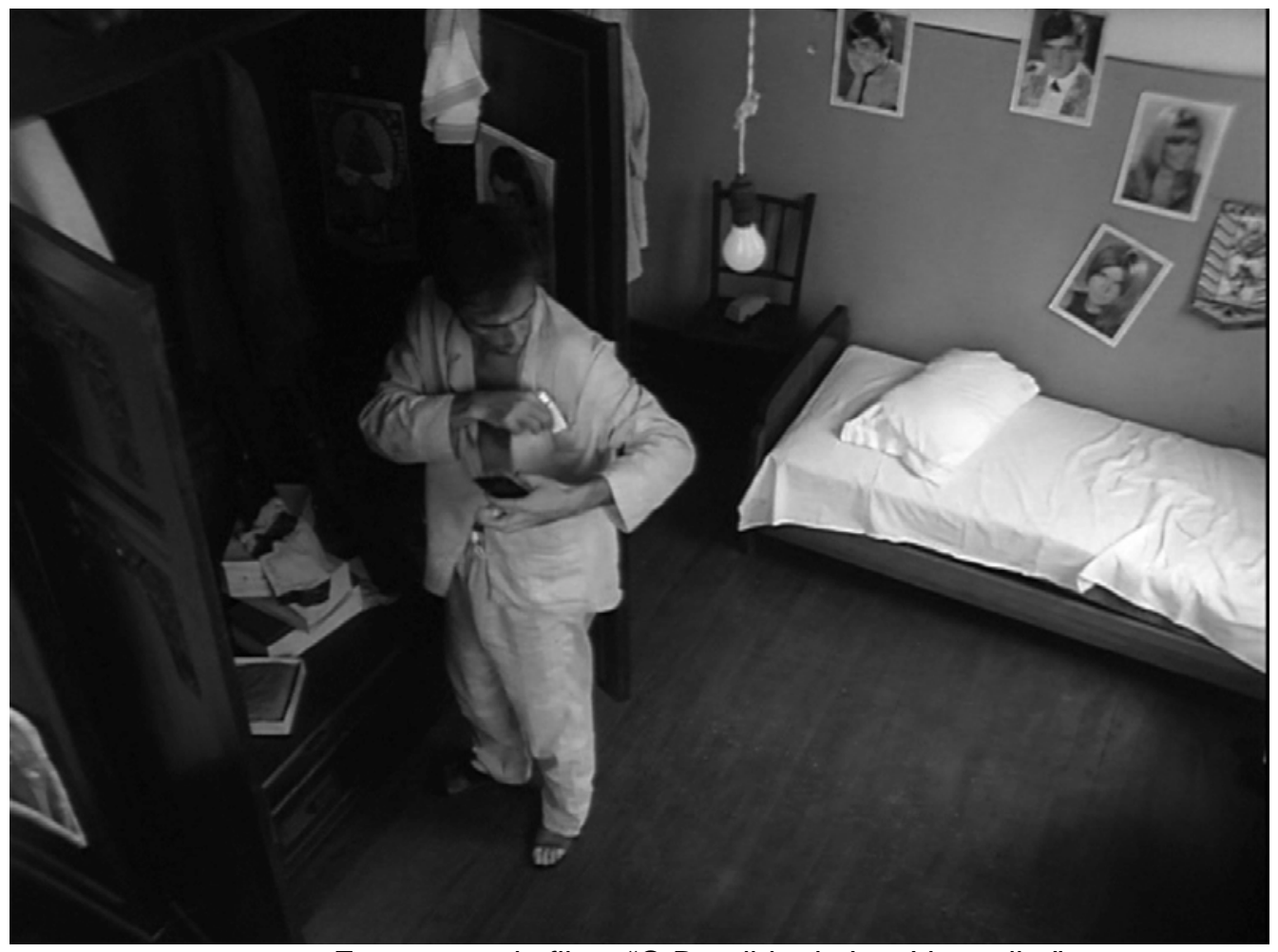

Fotograma do filme "O Bandido da Luz Vermelha" 
Nas cenas do quarto do Bandido, pode-se observar a densidade kitsch do ambiente. Coleções de objetos, gaiolas, decoração desarmônica, feita da estátua de São Jorge, da imagem da Nossa Senhora Aparecida, o retrato de Wanderley Cardoso, mobiliário velho e simples.

O personagem central repete várias vezes a frase: "Quem sou eu?". Numa destas situações, o Bandido está se preparando para se barbear num banheiro. Veste um pijama clássico masculino de cor clara, amarrotado, visto anteriormente na figura 16. Neste banheiro existem três espelhos que multiplicam as imagens e o espaço. Com o creme de barbear, o protagonista primeiro cobre o seu reflexo em um dos espelhos para depois passar a espuma no seu rosto e começar a se barbear. Em seguida borra a sua imagem no espelho, passando a mão e espalhando o creme. Sobre este gesto, entra em off a pergunta: "Quem sou eu?". Nesse momento, o Bandido vira-se de costas para o seu reflexo e dispara o spray espalhando espuma de barbear por todo o banheiro.

\begin{abstract}
Não há fronteira entre as faces do bandido, que seriam o alvo do creme de barbear, e o conjunto do espaço em geral, não há demarcação entre o bandido e o espaço circundante. Eu é o mundo todo. Se quisermos carregar metaforicamente a espuma de barbear com um sentido espermático, acrescentaremos que 0 desejo do bandido espalha-se em todas as direções, não há pontos sobre os quais convirja. A sequência do banheiro é provavelmente o momento em que essa relação bandido/espaço circundante/desejo encontra-se graficamente mais clara (BERNADET, 1990, p.165).
\end{abstract}

"O Bandido da Luz Vermelha" tem algumas sequências ambientadas em salas de cinema, característica dos filmes desta época. Numa delas, uma mulher desloca-se de cadeira, incomodada pelo assédio de um espectador. O Bandido está com a camisa bicolor, mencionada anteriormente. Ele come uma espiga de milho com a perna por cima da poltrona da frente, exibindo suas meias, botas fotografadas como pretas e calça escura de boca estreita. De vez em quando, usa um binóculo para assistir à tela grande (figura 64). A câmera revela a presença de outros cineastas fazendo uma ponta no filme, tais como Carlos Reichenbach, Antonio Lima e o próprio Rogério Sganzerla.

Quando o Bandido deixa a sala de exibição, é possível ver as imagens da Boca com seus outdoors, cartazes e fachadas de cinema, mostradas na figura 65. "A ligação entre o comércio cinematográfico e a Boca do Lixo se estampa na paisagem urbana onde circula o bandido (...)" (XAVIER, 1993, p.93). 
Figura 64 - O Bandido assiste a um filme com binóculos.

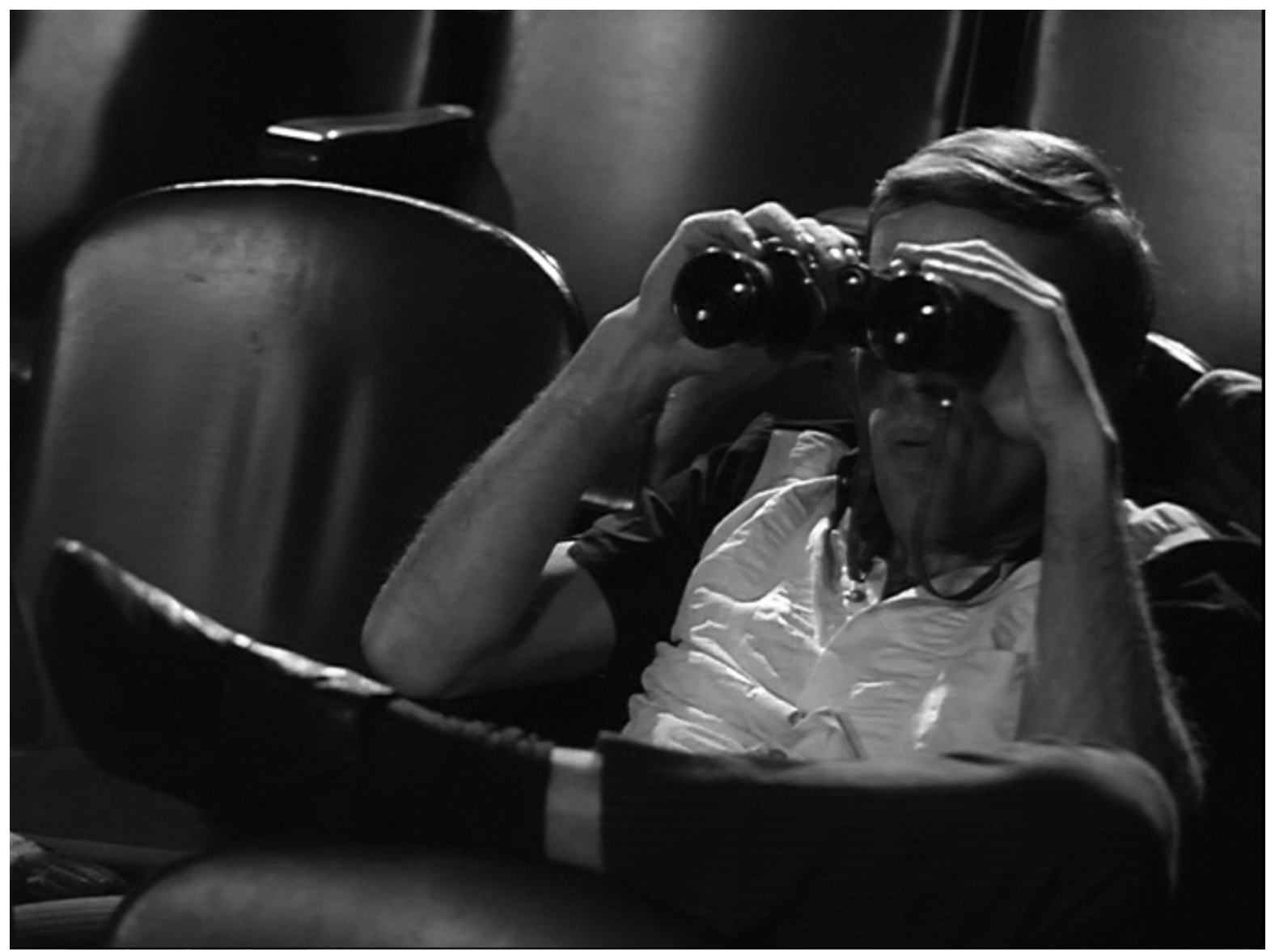

Fotograma do filme "O Bandido da Luz Vermelha"

Em seguida, o protagonista joga fotos ou dinheiro para o alto, deixando que as notas ou fotografias se esparramem pelo chão. Nesta ação, ele está com o mesmo figurino que estava dentro da sala de cinema na figura 64 , associado a um casaco carregado com uma das mãos por cima do ombro. O casaco, jogado displicentemente no ombro, oferece movimento ao figurino e ao mesmo tempo deixa a figura assimétrica, como se observa na figura 65. A calça com a boca estreita e ligeiramente curta evidencia as botas escuras de cano curto usadas pelo protagonista, item constante no figurino do Bandido e destacado pelos três entrevistados desta pesquisa (Carlos Ebert, Helena Ignez e Julio Calasso Junior), como se o ator Paulo Villaça também tivesse uma paixão pelo uso de botas. 0 diretor de fotografia Carlos Ebert comenta, em tom de brincadeira, que "a mania pelas botinhas" do ator Paulo Villaça era tão grande que a equipe dizia "Este personagem tem um traço de Sacker Masoch" (EBERT, 2013). 
Figura 65 - O Bandido diante das fachadas dos cinemas.

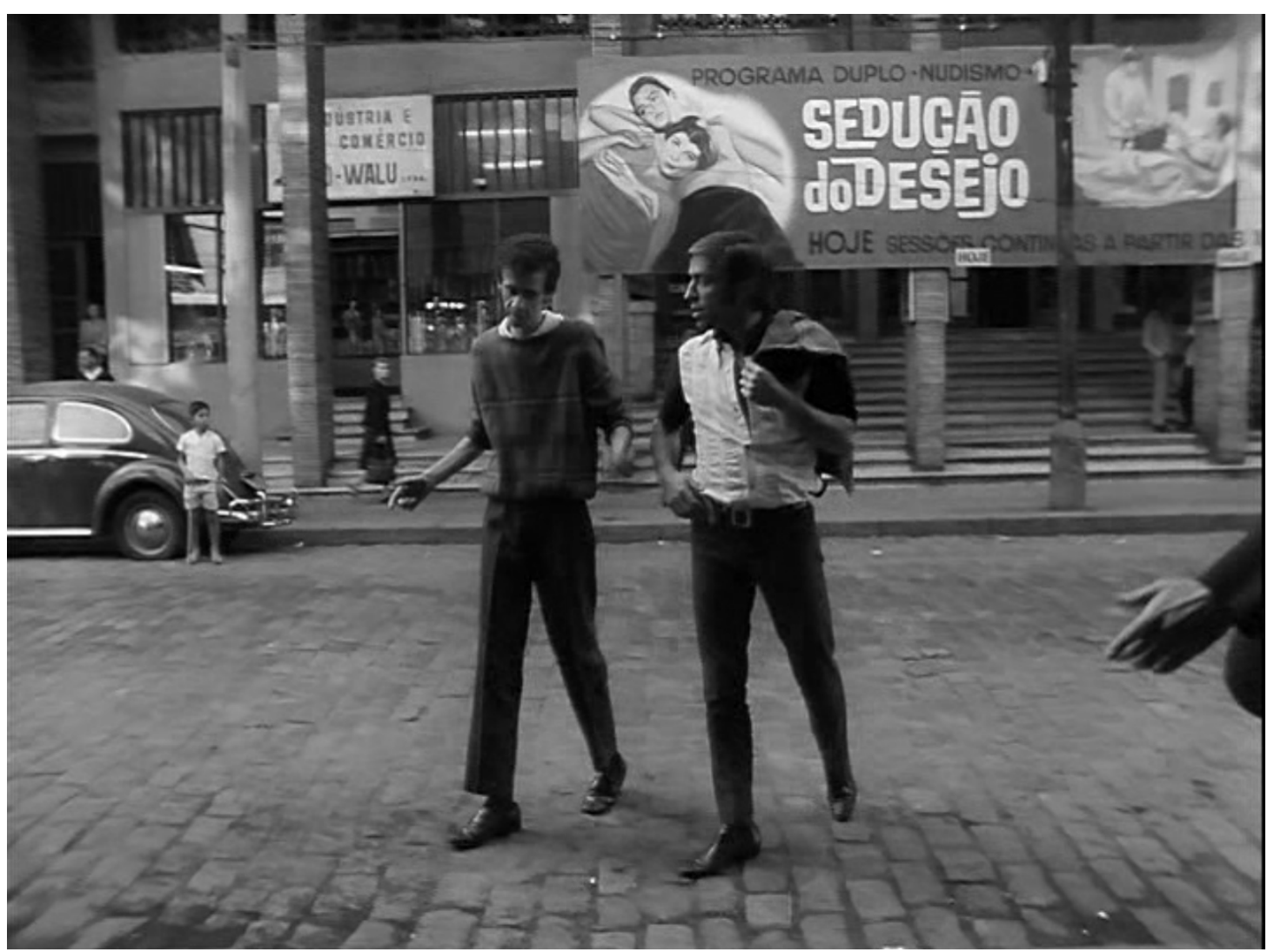

Fotograma do filme "O Bandido da Luz Vermelha"

Algumas cenas também apresentam grandes semelhanças com os assaltos reais realizados pelo criminoso João Acácio. Uma delas é um assalto que o personagem central faz e defronta-se com uma empregada doméstica que vai fazer o café. O diálogo entre os dois é muito parecido com um diálogo transcrito no jornal Folha de São Paulo entre uma doméstica e o verdadeiro bandido João Acácio. Na fita, ela pergunta ao Bandido: "Com que direito o senhor entra assim na casa dos outros sem pedir licença?". Ele responde: "Desde quando ladrão pede licença?". Nesta cena, o protagonista usa uma camisa manga longa com estampa psicodélica, muito utilizada na época. A camisa é leve e ampla, provavelmente em seda. Ele tem o rosto coberto com um lenço, também em seda, o que deixa sua voz pouco audível. O personagem usa este lenço em vários assaltos que comete. O figurino do Bandido contrasta com o uniforme claro usado pela doméstica, que possui uma ligeira textura quadriculada. O traje da moça quase mimetiza com a parede clara da casa e a estampa psicodélica da camisa do protagonista fica em destaque, acentuando o lado atrevido do personagem (figura 66). 
Figura 66 - O Bandido usa camisa com estampa psicodélica.

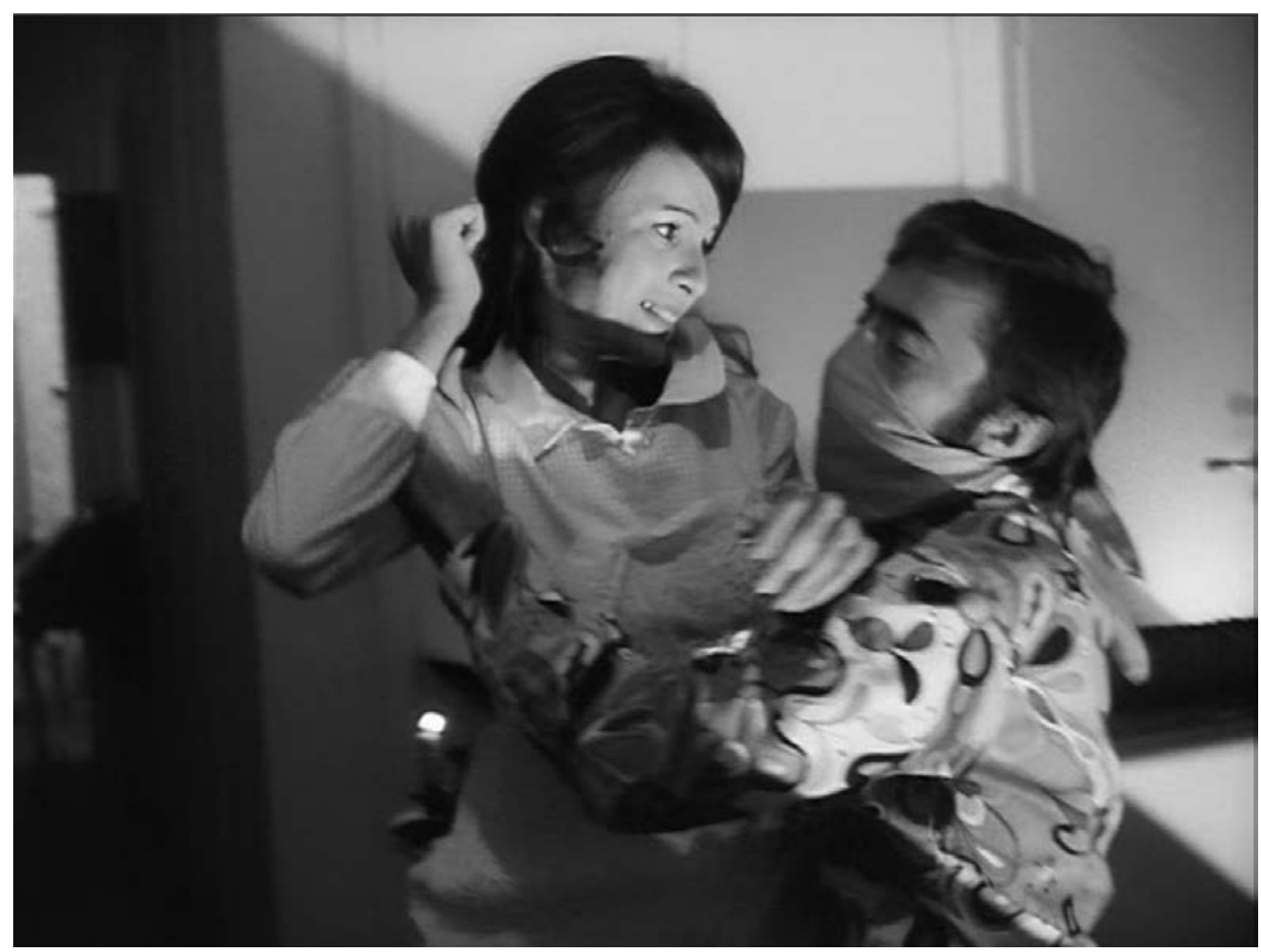

Fotograma do filme "O Bandido da Luz Vermelha"

É importante apontar a cena onde a "Madame Misteriosa", interpretada pela atriz russa-brasileira Lola Brah, liga para a polícia e passa informações sobre o Bandido. Em um primeiro momento, ela está diante de um pôster de cinema, ao telefone, vestindo um casaco de lã claro com gola e punhos de pele e um anel grande com pedra escura. Fuma um cigarro com a piteira. O casaco é volumoso e pesado, o que enfatiza sua classe social e faz referência ao cinema americano. A personagem é uma caricatura da classe alta brasileira, a grã-fina. A cena se alterna em cortes, entre a Madame e o gabinete de polícia. Em um dos cortes, quando a câmera volta para a Madame, ela está vestindo outro figurino, agora escuro com mangas três quartos, colar de pérolas, óculos escuros e o mesmo anel. O pôster de cinema ao fundo do quadro também é outro. A troca de figurino comprova a falta de continuidade, característica do filme, como mostra a figura 67 e 68 . Em ambos os looks, a personagem está de cabelo preso, milimetricamente penteado. Normalmente o cabelo de mulher usado preso sugere hábitos de autocontrole, acompanhados, frequentemente, de opiniões conservadoras, como aponta Lurie (1997). 
Figura 67 - Primeiro figurino da "Madame Misteriosa".

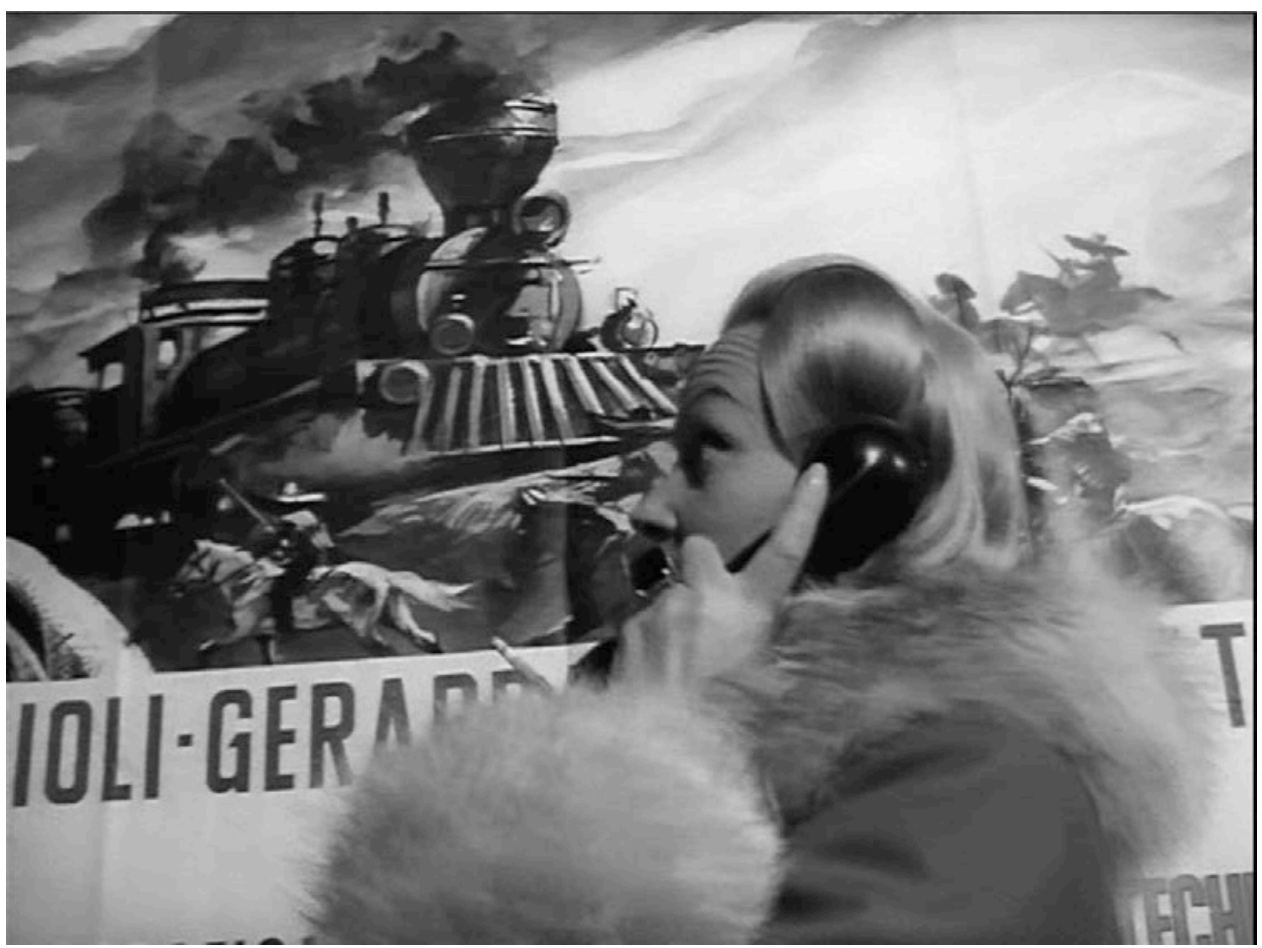

Fotograma do filme "O Bandido da Luz Vermelha"

Figura 68 - Segundo figurino da "Madame Misteriosa".

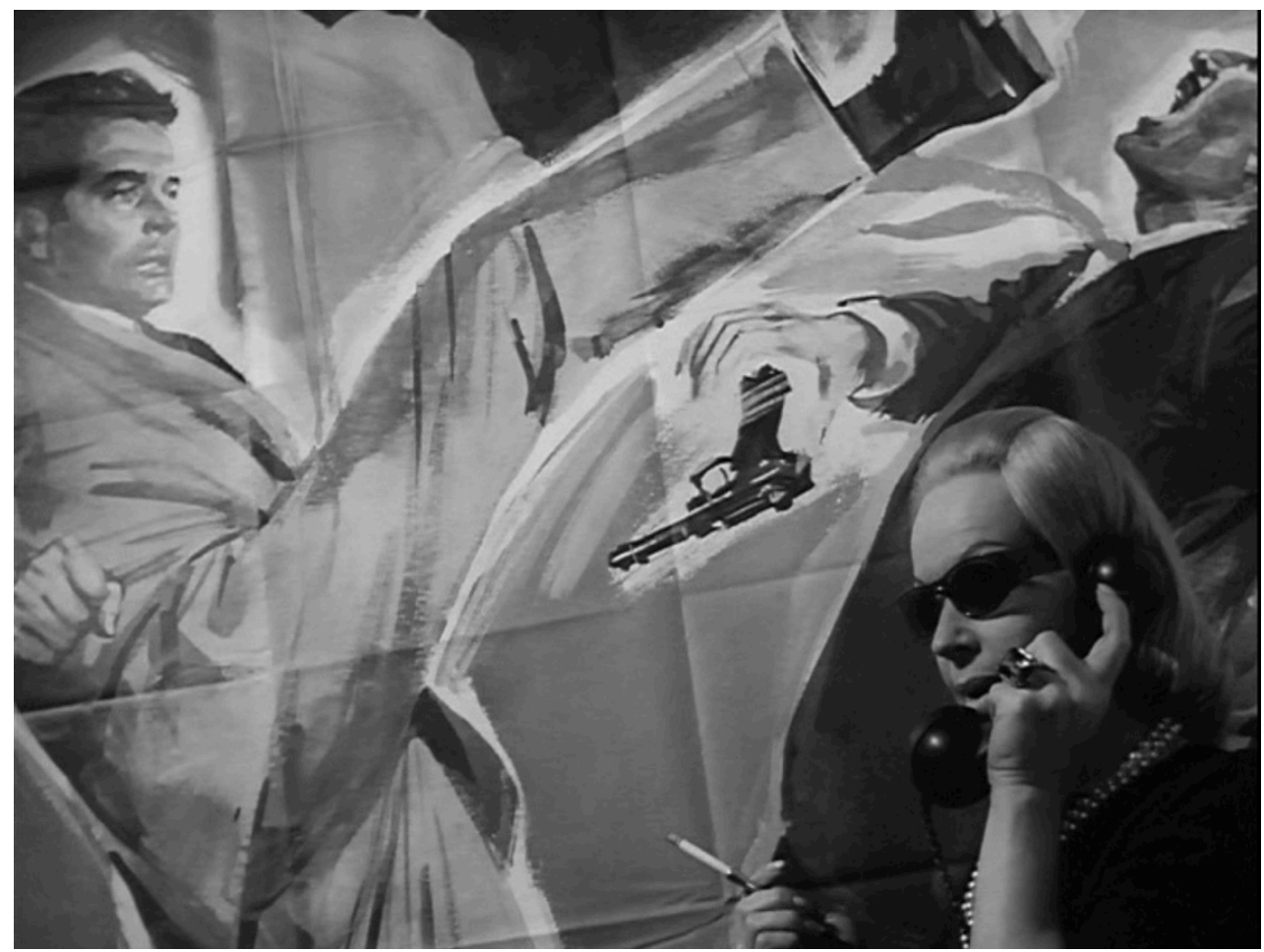

Fotograma do filme "O Bandido da Luz Vermelha" 
O espaço de tempo é elástico no filme. Não existe uma radical diferença entre o passado e o presente. A instabilidade temporal pode ser notada na cena em que as amantes do Bandido são descritas. Ele veste uma calça estreita listrada verticalmente e cinto com listras horizontais, como pode ser observado no detalhe da figura 69. As listras dos dois elementos do figurino são simétricas, regulares. 0 figurino é justo. A maioria dos figurinos do Bandido é próximo do corpo, artifício que alonga sua figura. Uma camisa escura manga longa com abotoamento duplo nos punhos, chapéu escuro com abas largas e debrum claro, fotografado preto e branco, compõem o look. O chapéu, assim como o cabelo, expressa ideias e opiniões. A convenção hollywoodiana para este acessório é: chapéu branco para o "Mocinho" e chapéu preto para o "Bandido". Portanto homens que desejam parecer rebeldes ou personagens temerários preferem as cores escuras, e os mais corretos, as mais claras (LURIE, 1997).

Figura 69 - Detalhe da calça e cinto do Bandido.

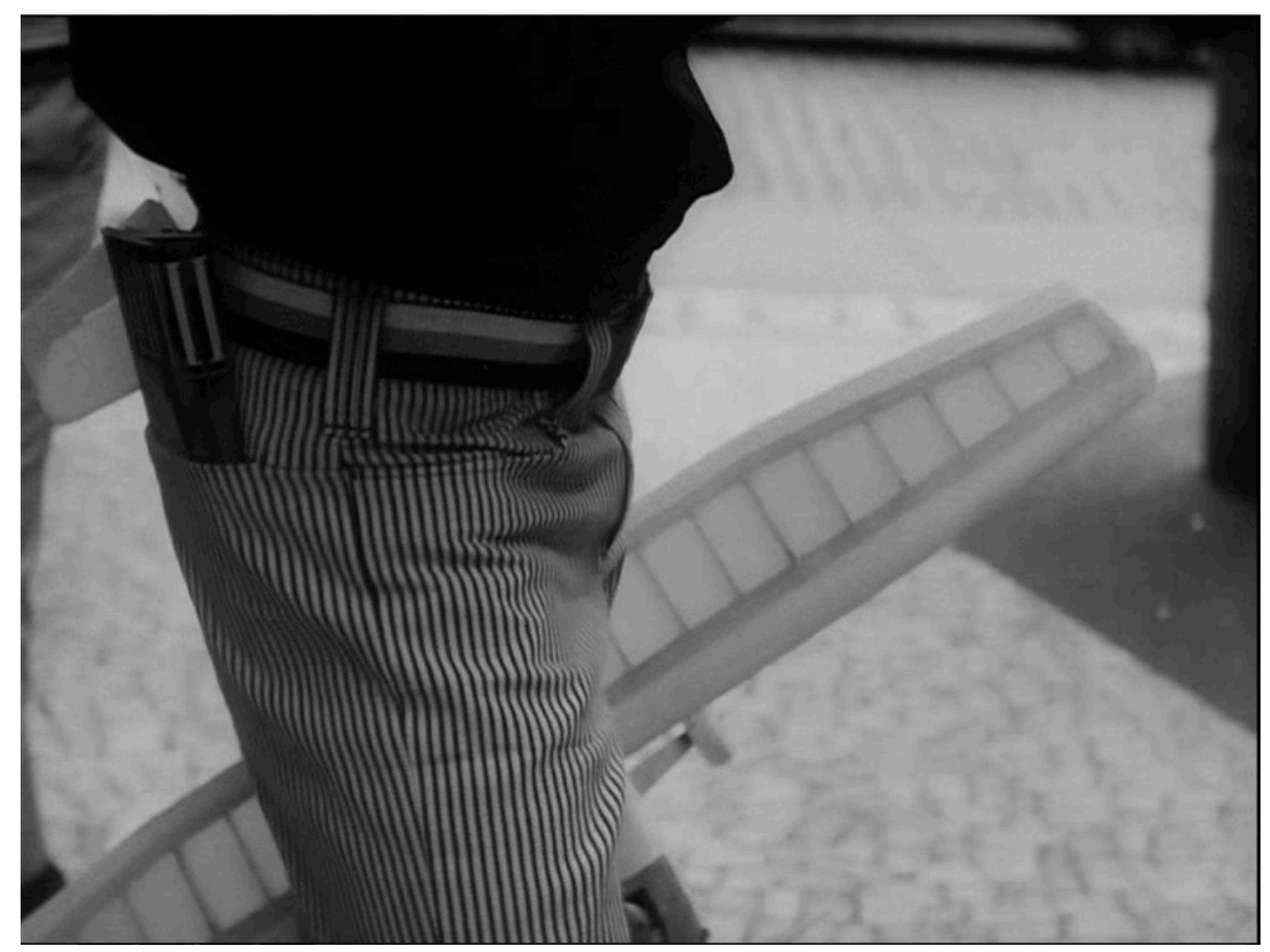

Fotograma do filme "O Bandido da Luz Vermelha" 
Ele também usa um bigode postiço e as costeletas estão bastante evidentes (figura 70) enquanto segura um planador de brinquedo. Depois, o personagem aparece deitado na relva e ao seu lado aterrissa um planador de brinquedo. Logo após, ele faz compras e toma um taxi segurando o planador que acabara de comprar. Estas cenas descontínuas são intercaladas com cenas onde aparece o protagonista pichando um muro com outro figurino, calça com listras largas e camisa clara com colarinho alto, abotoamento duplo, para fora da calça (figura 71).

Figura 70 - O Bandido e o planador que comprou.

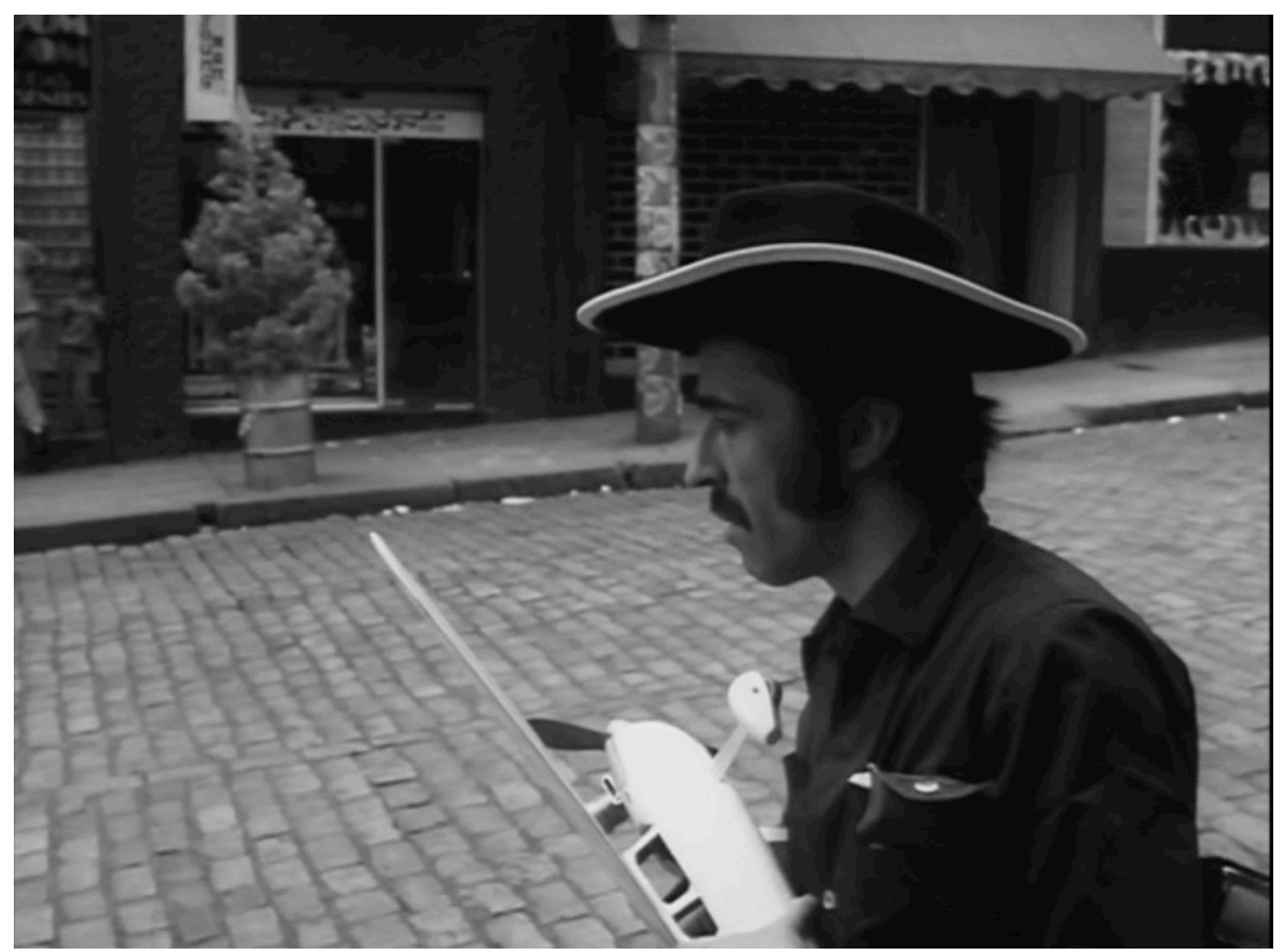

Fotograma do filme "O Bandido da Luz Vermelha"

Vale mostrar duas das amantes do Bandido, descritas nas cenas anteriores. Elas trazem todos os elementos da época, evidenciando que a trama da história se passa nos anos 60. Uma delas está com a maquiagem difundida pela famosa modelo inglesa Twiggy, ícone da década, feita com delineador preto, mostrada na figura 72. A outra fala ao telefone em frente a uma janela com uma saia calça clara, camisa em tom mais claro, sapato mocassim escuro, cabelo com volume, look clássico da década (figura 73). 
Figura 71 - Cena intercalada onde o Bandido picha o muro.

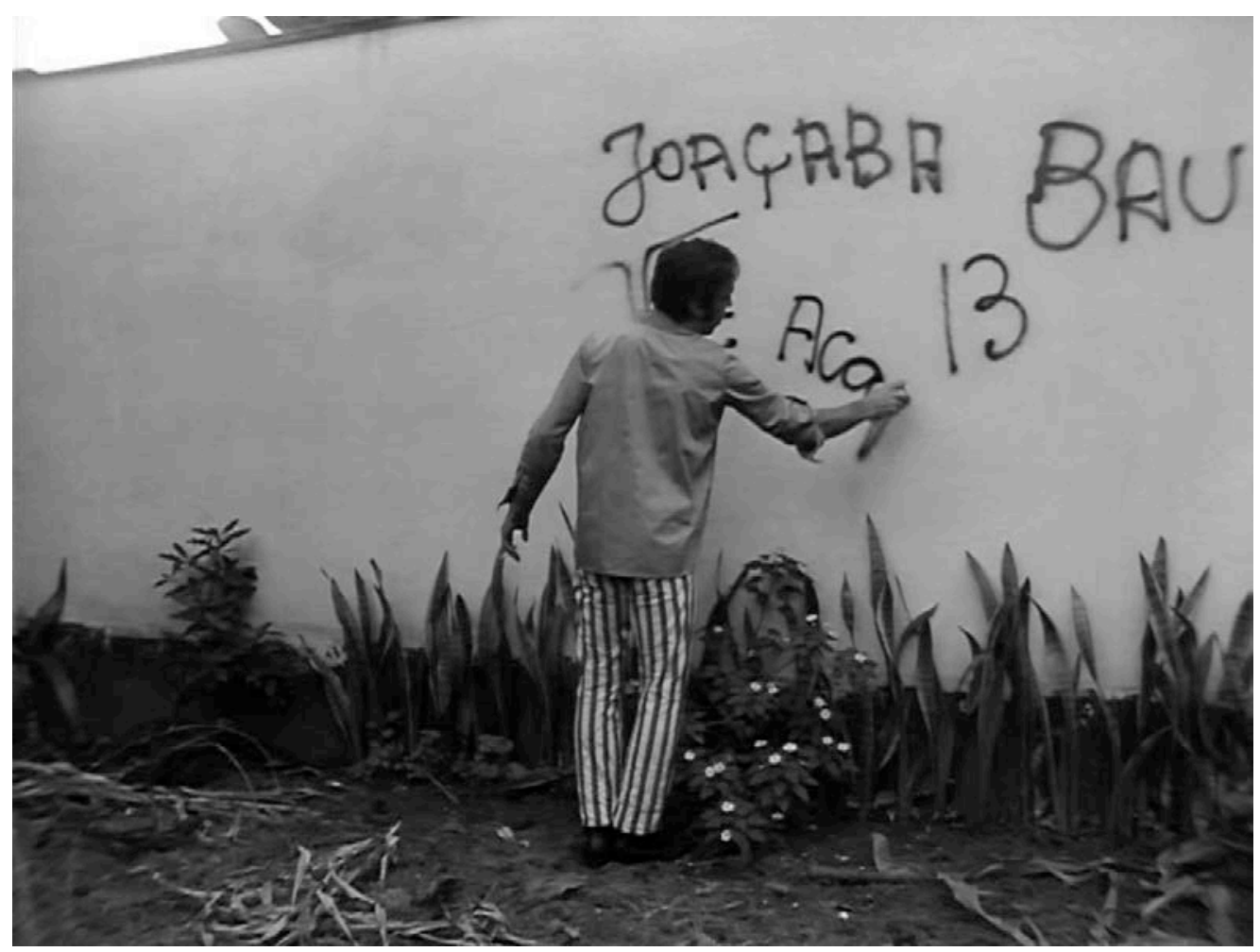

Fotograma do filme "O Bandido da Luz Vermelha"

Figura 72 - Uma das amantes do Bandido com maquiagem da época.

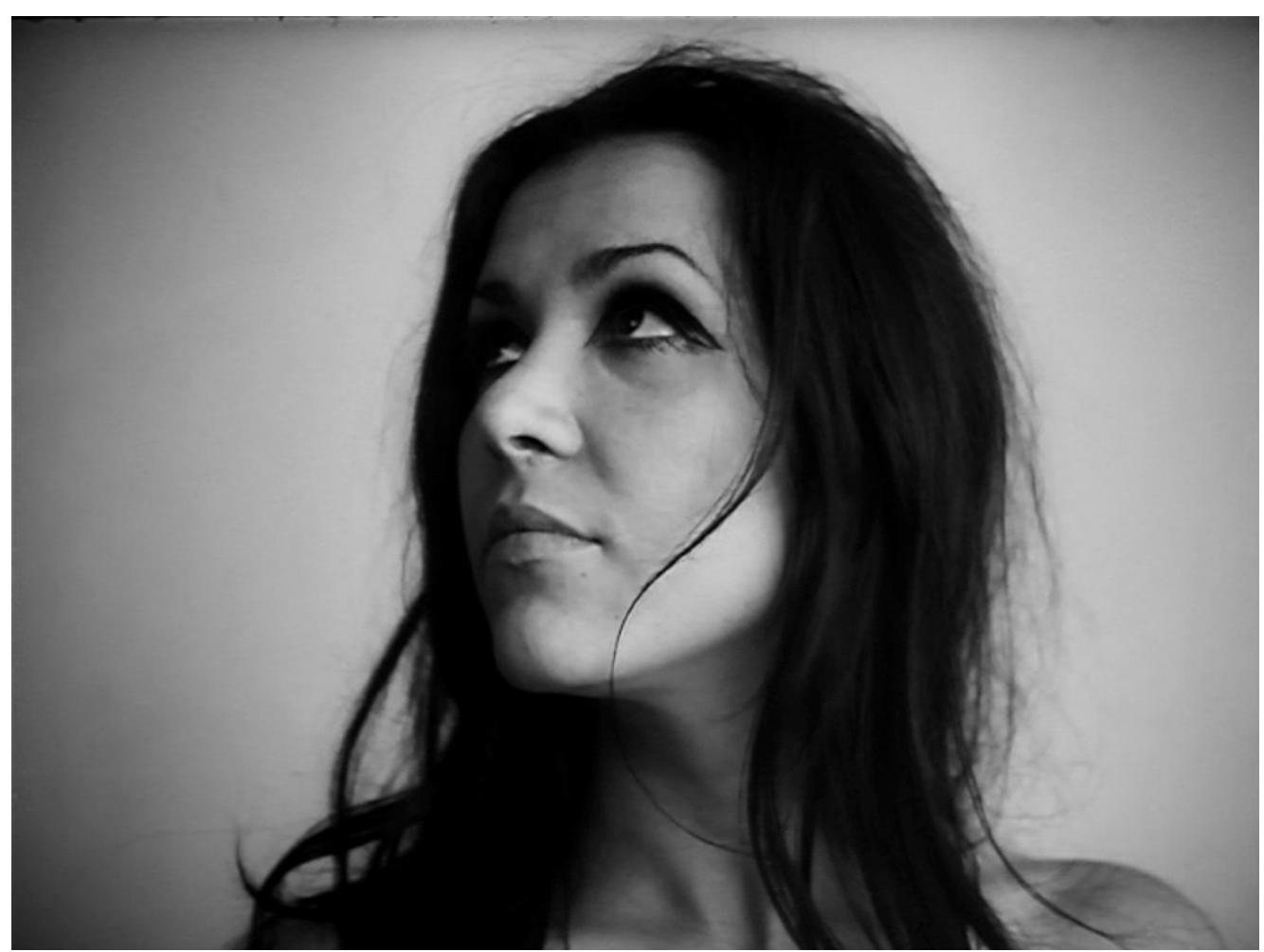

Fotograma do filme "O Bandido da Luz Vermelha" 
Figura 73 - Outra amante do Bandido com look clássico da década de 60.

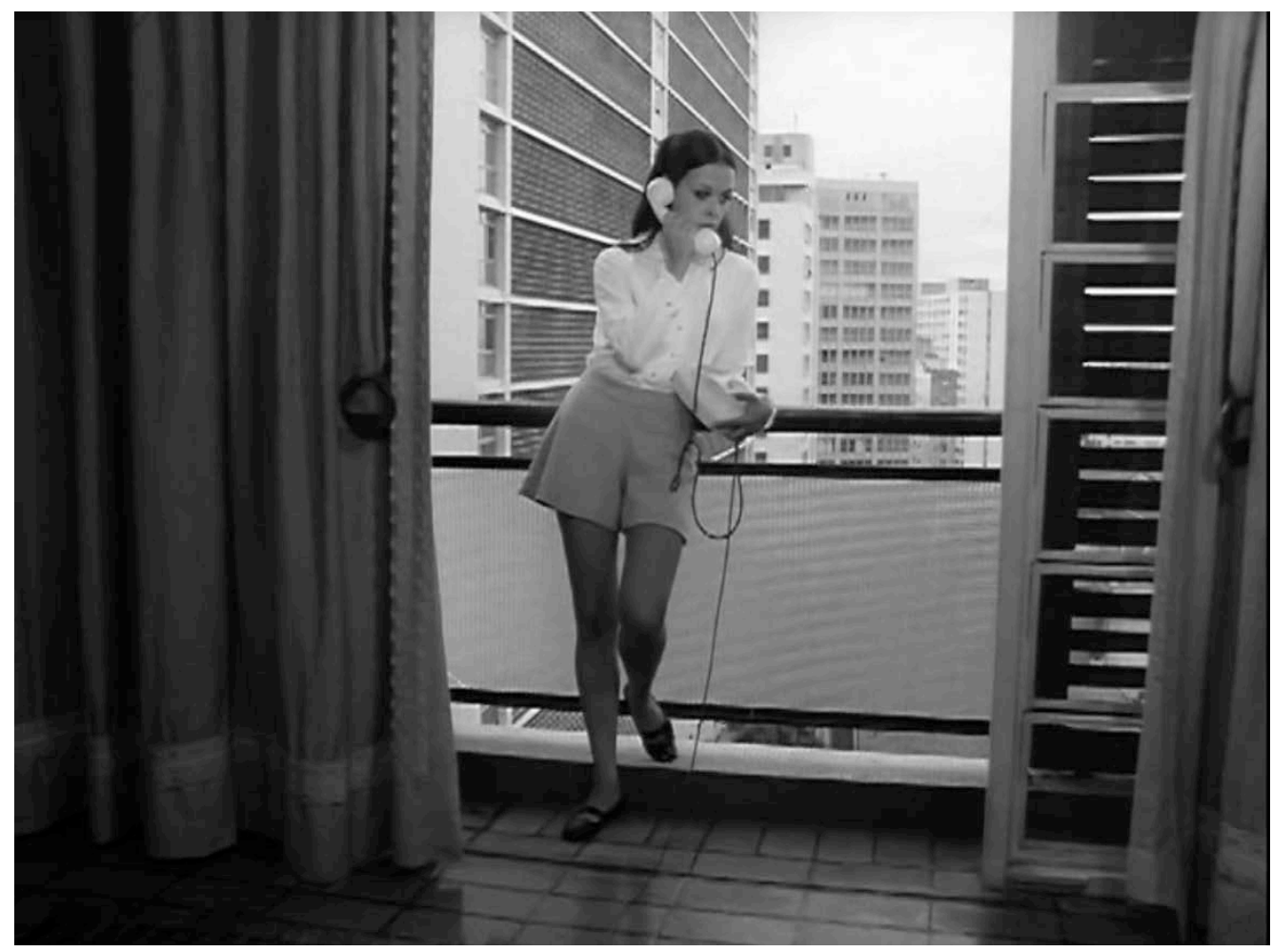

Fotograma do filme "O Bandido da Luz Vermelha"

Outro personagem bastante bizarro é o "Gay exagerado", interpretado por Sergio Mamberti, que dá receita de pudim ao Bandido, quando ele está disfarçado de motorista de táxi. O personagem usa uma camisa manga curta estampada, um foulard escuro com estampa de bolinhas amarrado no pescoço de maneira assimétrica, com movimento quando ele caminha. Segundo Lurie (1997), as bolinhas menores associam-se, de alguma maneira, a um humor em grande parte verbal, uma sagacidade, sátira e ironia sofisticadas. A calça bem estreita e justa parece estar com o zíper aberto, como pode ser observado na figura 74 . Sandálias completam o desenho da figura.

O personagem está de óculos escuros, vários anéis, relógio tipo bracelete, visíveis na figura 75. Segura um gatinho nos braços e uma sacola de material plástico. É bastante caricato e anda rebolando, dando pequenos gritos e beijando o gato. Todos os elementos do figurino demonstram a fragilidade e o lado feminino do personagem, camisa e foulard em tecidos leves, calça agarrada ao corpo e sandálias. O foulard dá ação ao ator, que mexe constantemente na peça, quando está dentro do carro. Logo em seguida revela que usa cílios postiços, ao tirar de uma das pálpebras. 
Figura 74 - O "Gay exagerado" com o zíper aberto.

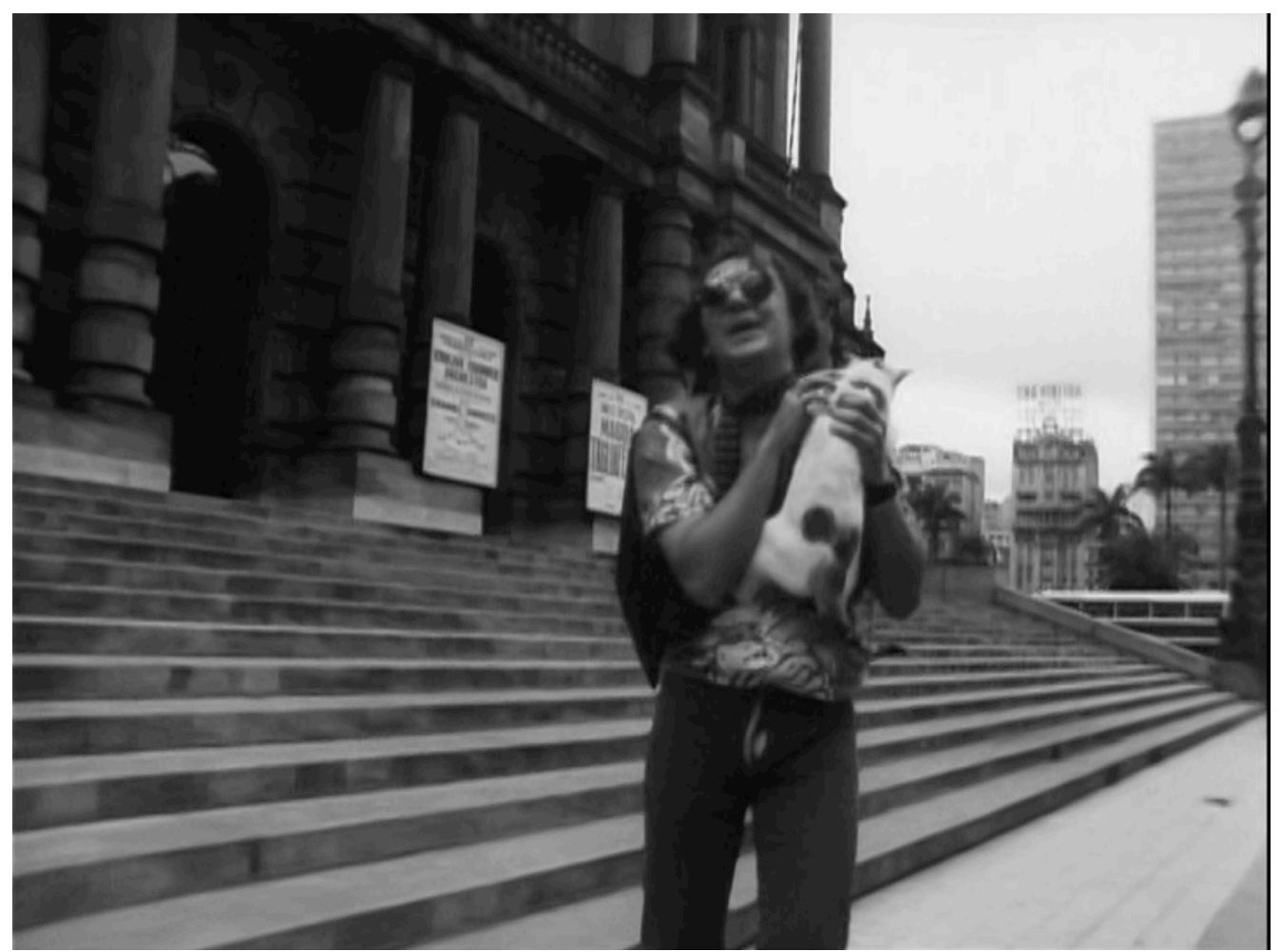

Fotograma do filme "O Bandido da Luz Vermelha"

Figura 75 - O "Gay exagerado" dá receita de pudim ao Bandido.

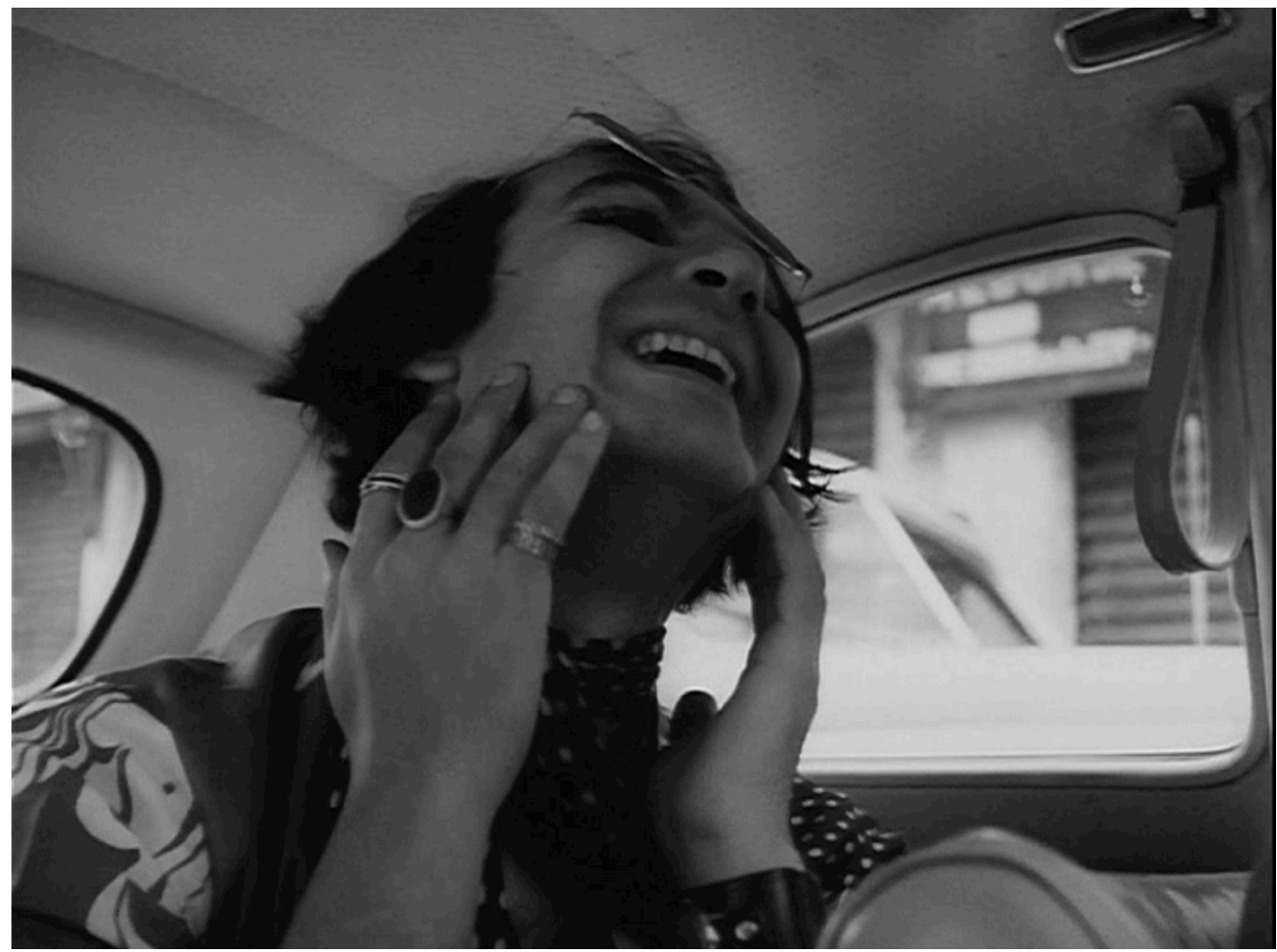

Fotograma do filme "O Bandido da Luz Vermelha" 
Bandido também troca de roupa em cena quando assassina um homem no jardim de sua própria casa. Antes da sequência do assassinato, existe uma cena onde o protagonista vasculha um guarda-roupa da casa. Ele veste uma calça justa com listras largas, clara e escura, e uma camisa de colarinho alto e abotoamento duplo, novamente o mesmo figurino mostrado na figura 71 . No momento do assassinato, o personagem central aparece com uma calça de cor única, escura e ampla, provavelmente que pegou do guarda-roupa da cena anterior. Após matar o homem, ele tira a calça de cor única e revela a calça listrada, nítido na figura 76. Talvez seja uma forma de não ser reconhecido pela polícia através de sua vestimenta, ou a prova de sua fixação por roupas.

Figura 76 - O Bandido troca de roupa no jardim.

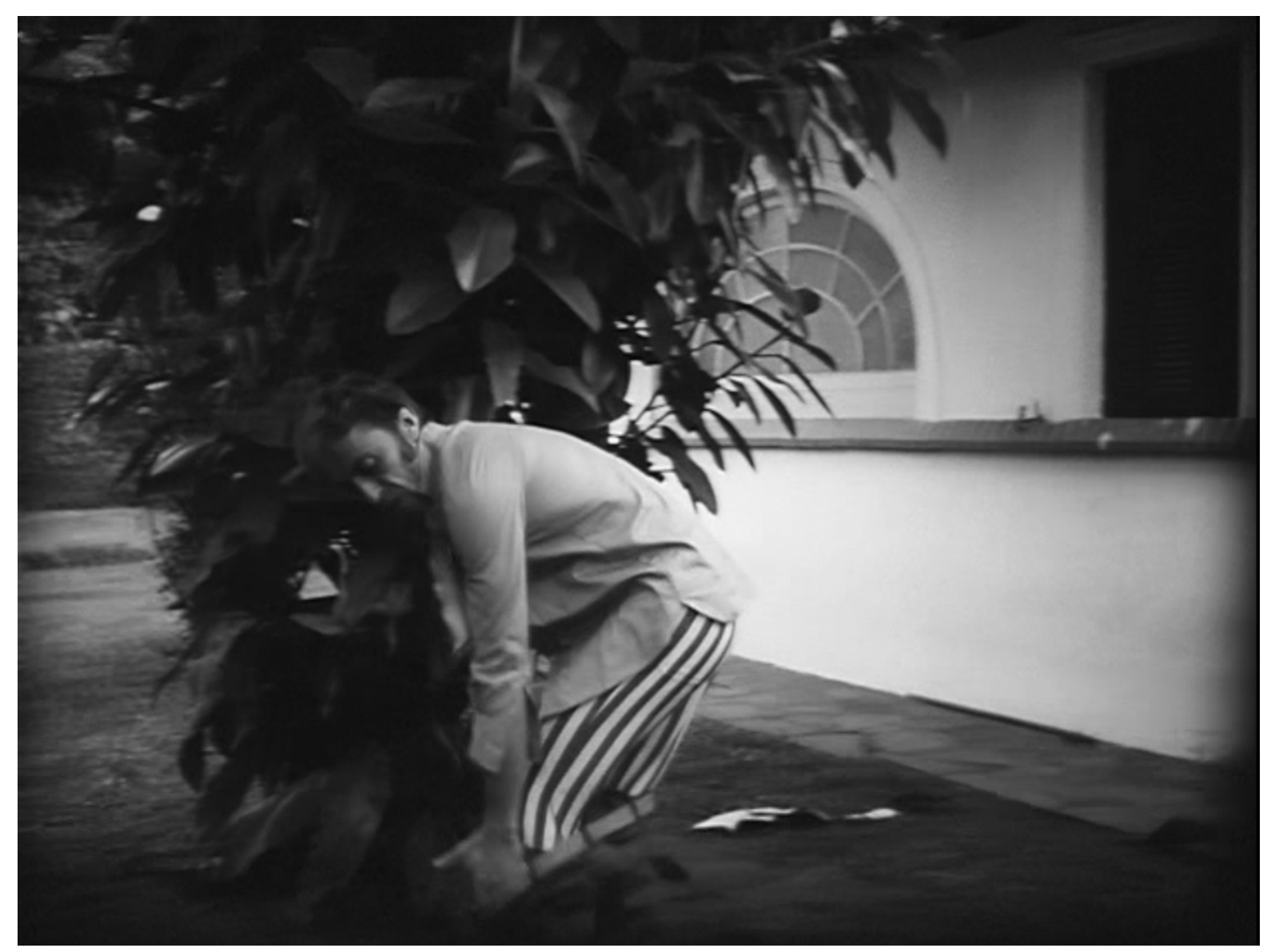

Fotograma do filme "O Bandido da Luz Vermelha"

A falta de continuidade de locação e figurino também é apresentada na cena em que o Bandido bebe tinta de um balde. Quando ele pega o balde está diante de um muro branco pichado, figura 77 . No momento em que bebe a tinta, o muro é 
escuro, coberto de folhas, figura 78. Ele veste uma calça justa com listras largas, camisa clara com colarinho alto e abotoamento duplo, uma espécie de dólmã usada pelos chefs de cozinha, que está para fora da calça e com as mangas simetricamente dobradas.

Figura 77 - O Bandido bebe tinta diante de muro branco com pichações.

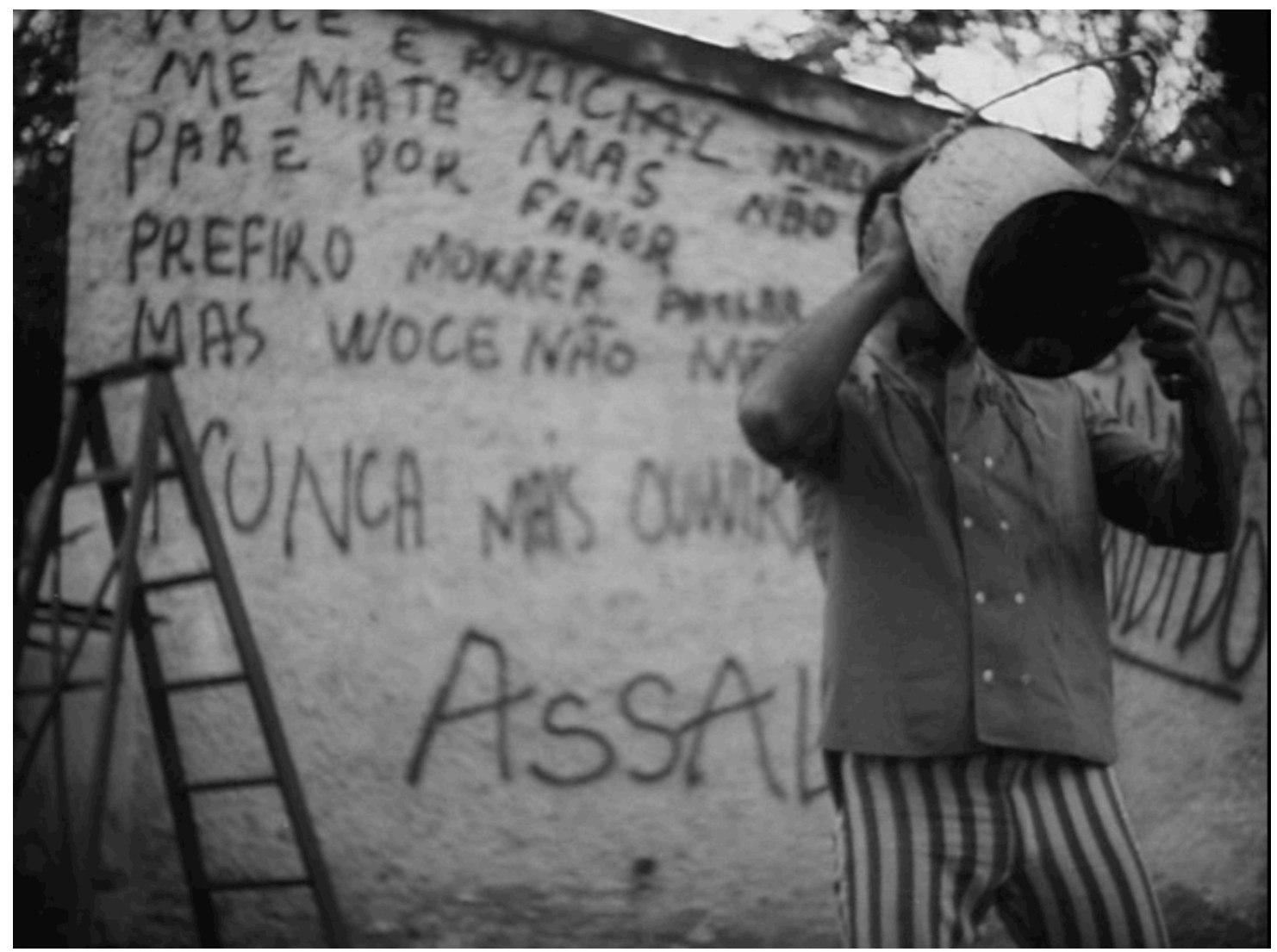

Fotograma do filme "O Bandido da Luz Vermelha"

Em seguida ele tira a camisa e tenta escalar o muro com o peito nu, para depois mergulhar numa piscina com camisa. Este figurino é repetido em algumas cenas ao longo da fita. Nesta, depois que o protagonista bebe a tinta, pode-se dizer que a máscara criada pela mancha de tinta no rosto e as calças listradas, plasticamente compõe a figura de um clown, como foi visto anteriormente na figura 11.

J. B. Da Silva, o candidato da Boca do Lixo, interpretado por Pagano Sobrinho, é outro personagem de grande importância no enredo do filme. Segundo Carlos Ebert, ele é uma "síntese do político brasileiro". Para ele, o político era o 
retrato do Tenório Cavalcanti ${ }^{23}$, do Assis Chateaubriand ${ }^{24}$, do Adhemar de Barros ${ }^{25}$, "de todos os políticos demagogos, populistas" (EBERT, 2013).

Sua primeira aparição, crucial para a junção fortemente estabelecida entre criminalidade e política, é durante a cena em que o Bandido bebe tinta do balde, detalhada anteriormente. Intercalado com a cena do balde, do muro e da piscina, vêse um avião aterrissar, vários planos do avião, até a saída de J.B. Da Silva do avião, descendo a escada triunfalmente.

Figura 78 - O Bandido bebe tinta diante de muro com folhas.

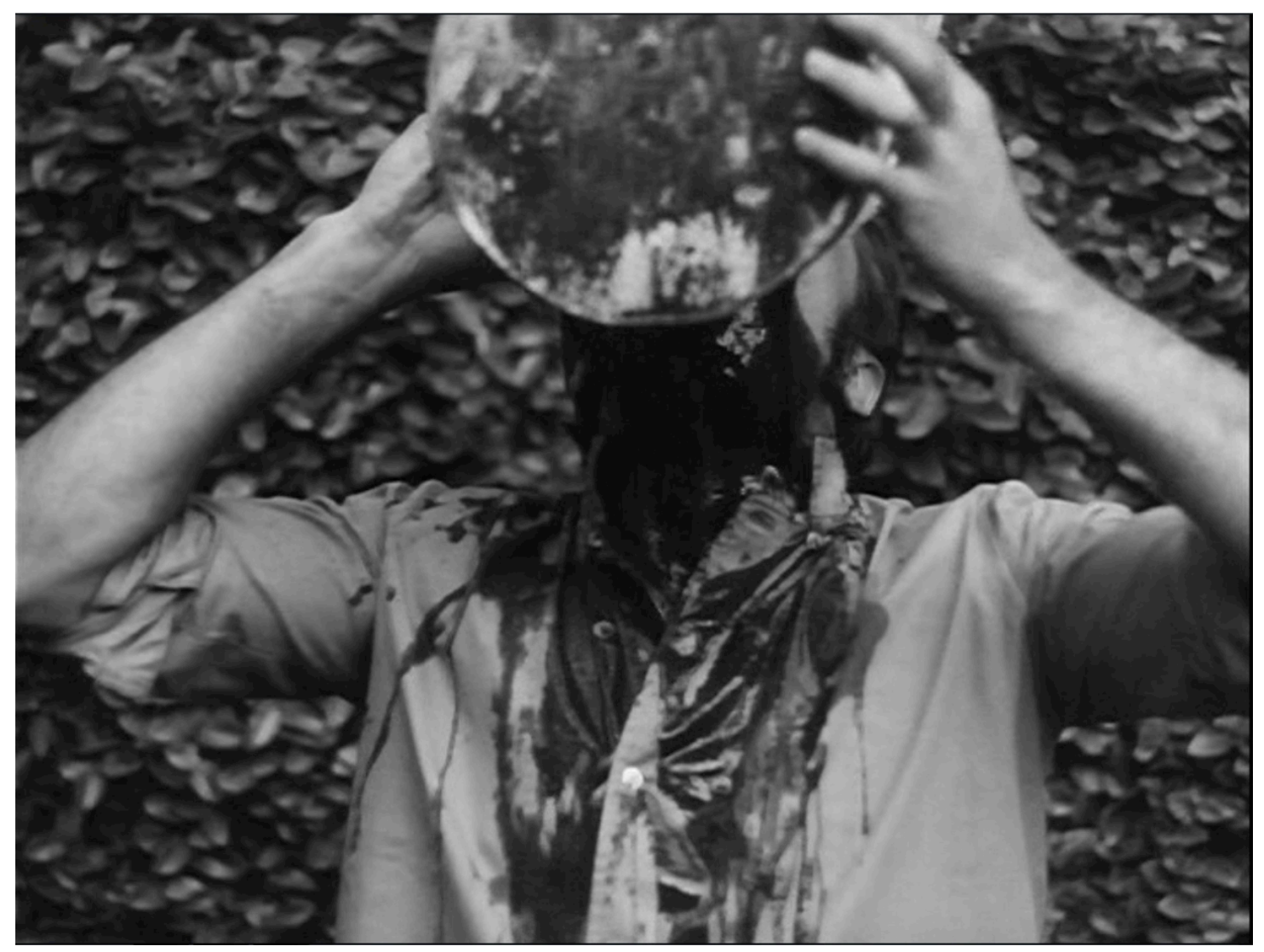

Fotograma do filme "O Bandido da Luz Vermelha"

J.B. Da Silva veste um terno escuro, como a maioria dos políticos da época. Camisa clara com abotoaduras e gravata escura com listras na diagonal discretas, tom sobre tom. Usa óculos escuros e um chapéu médio tom de abas estreitas, que permite ao ator realizar a saudação ao público. Os óculos escuros acentuam a falta

\footnotetext{
${ }^{23}$ Tenório Cavalcanti (1906-1987): Advogado e político brasileiro com base eleitoral no Estado do Rio de Janeiro.

${ }^{24}$ Assis Chateaubriand (1892-1968): Conhecido com Chatô, foi um jornalista, empresário e político, destacandose como um dos homens públicos mais influentes do Brasil nas décadas de 40 e 60 .

${ }^{25}$ Adhemar de Barros (1901-1969): Influente político brasileiro entre as décadas de 30 e 60. Foi prefeito da cidade de São Paulo e duas vezes governador do Estado de São Paulo.
} 
de credibilidade do personagem, de maneira que não é possível observar o seu olhar. Figurino regular, simétrico (figura 79). Completa a atuação do ator um sorriso no rosto estilo Getúlio Vargas.

Figura 79 - J.B. Da Silva desce do avião.

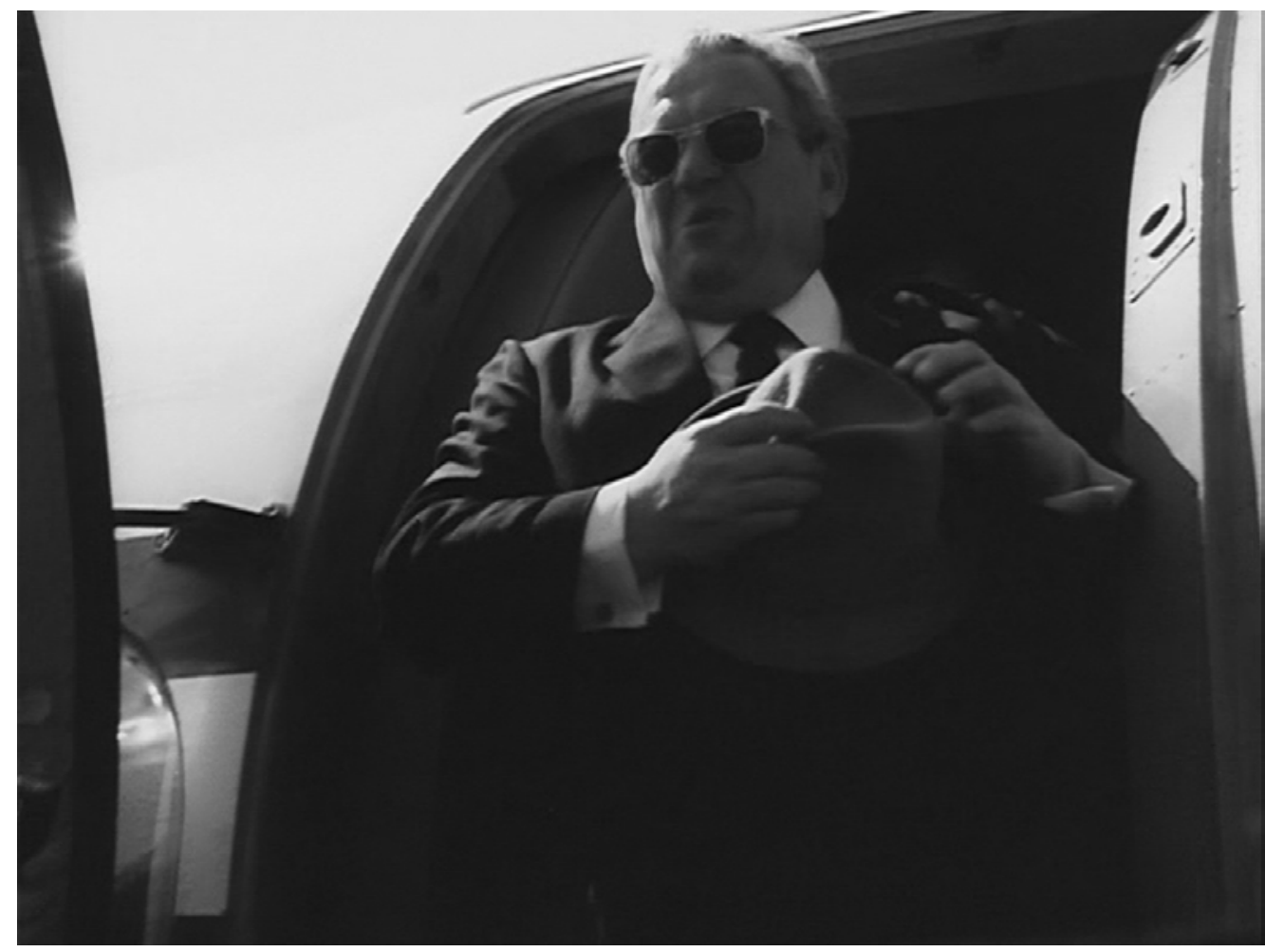

Fotograma do filme "O Bandido da Luz Vermelha"

Logo em seguida, Janete Jane aparece na tela de corpo inteiro. Ela está numa rua da Boca do Lixo encostada em um carro conversível em típica posição de "garota de programa" à espera de Jorginho (nome pelo qual ela chama o Bandido). A personagem usa o mesmo figurino praticamente todas suas aparições: camiseta canelada manga curta fotografada como branca, minissaia de cetim matelassê escura, cinto de argolas preso de maneira assimétrica, botas de cano médio clara com pequena abertura nos dedos e bolsinha clara de material maleável. Segundo a atriz Helena Ignez, as botas eram brancas e autênticas Courrèges, a minissaia era Mary Quant, e a camiseta emprestada de uma amiga. Por baixo da camiseta ela usava um soutien pontudo, típico dos anos 50, como se observa na figura 80 . 0 figurino é harmônico, com contrastes (claro e escuro, blusa leve e saia encorpada) que evidenciam a beleza da atriz, a camiseta ajustada ao corpo revela o lado sexy da personagem (IGNEZ, 2015). 
Figura 80 - Janete Jane aguarda o Bandido chegar.

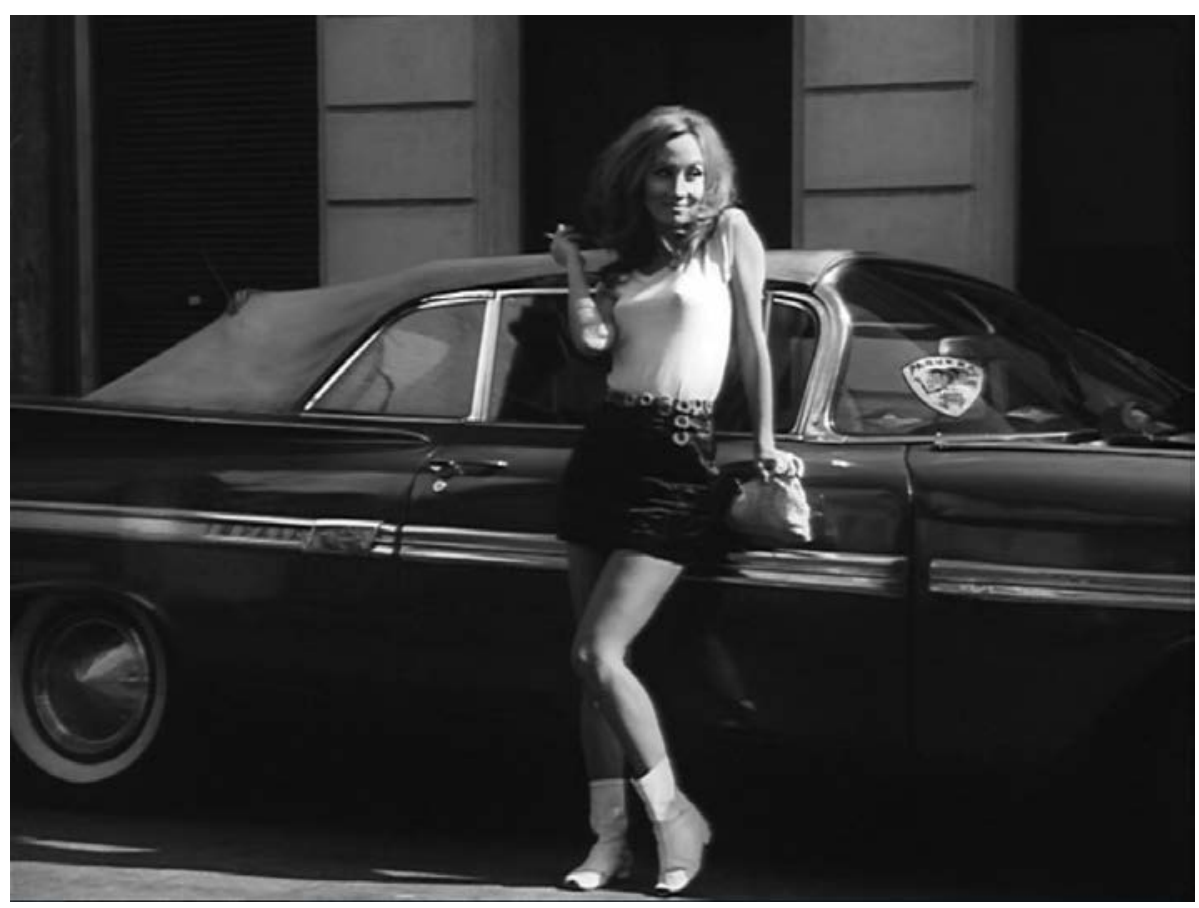

Fotograma do filme "O Bandido da Luz Vermelha"

Quando o Bandido chega, Janete Jane se aproxima do carro e neste momento é possível enxergar que a personagem usa um colar com um pingente geométrico. Outro item fundamental na caracterização da personagem é a beleza (cabelo e maquiagem). Os olhos são escuros, com delineador, cílios postiços e lábios contornados; ela também tem uma pinta no canto direito do lábio inferior. O cabelo loiro é penteado com volume característico da época, as unhas são compridas, pintadas com esmalte claro cintilante, como mostra a figura 81. Janete Jane entra no carro, que também é conversível, e o casal se dirige para a Baixada Santista. Conversam como novos ricos a simular grandes viagens.

O Bandido possui uma visão negativa de si mesmo quase durante toda a fita. Comprova-se esta atitude quando ele explica à Janete Jane: "Antigamente eu queria ser grande (...), ser famoso, ser o bacana pro bem e pro mal (...) meu negócio era o poder". E continua: "Eu sei que fracassei"; "posso dizer de boca cheia: eu sou um boçal"; "hoje eu sei que sou um coitado, não sou nada" (BERNADET, 1990, p. 204). O protagonista inicia o texto dentro do carro, vestindo um figurino listrado. Janete Jane usa biquíni médio tom (figura 82). A câmera vai girando enquanto o Bandido continua falando. Quando ele desce do carro, nota-se que ele veste um roupão, com listras largas e contrastantes (figura 83). 
Figura 81 - Janete Jane encosta no carro do Bandido.

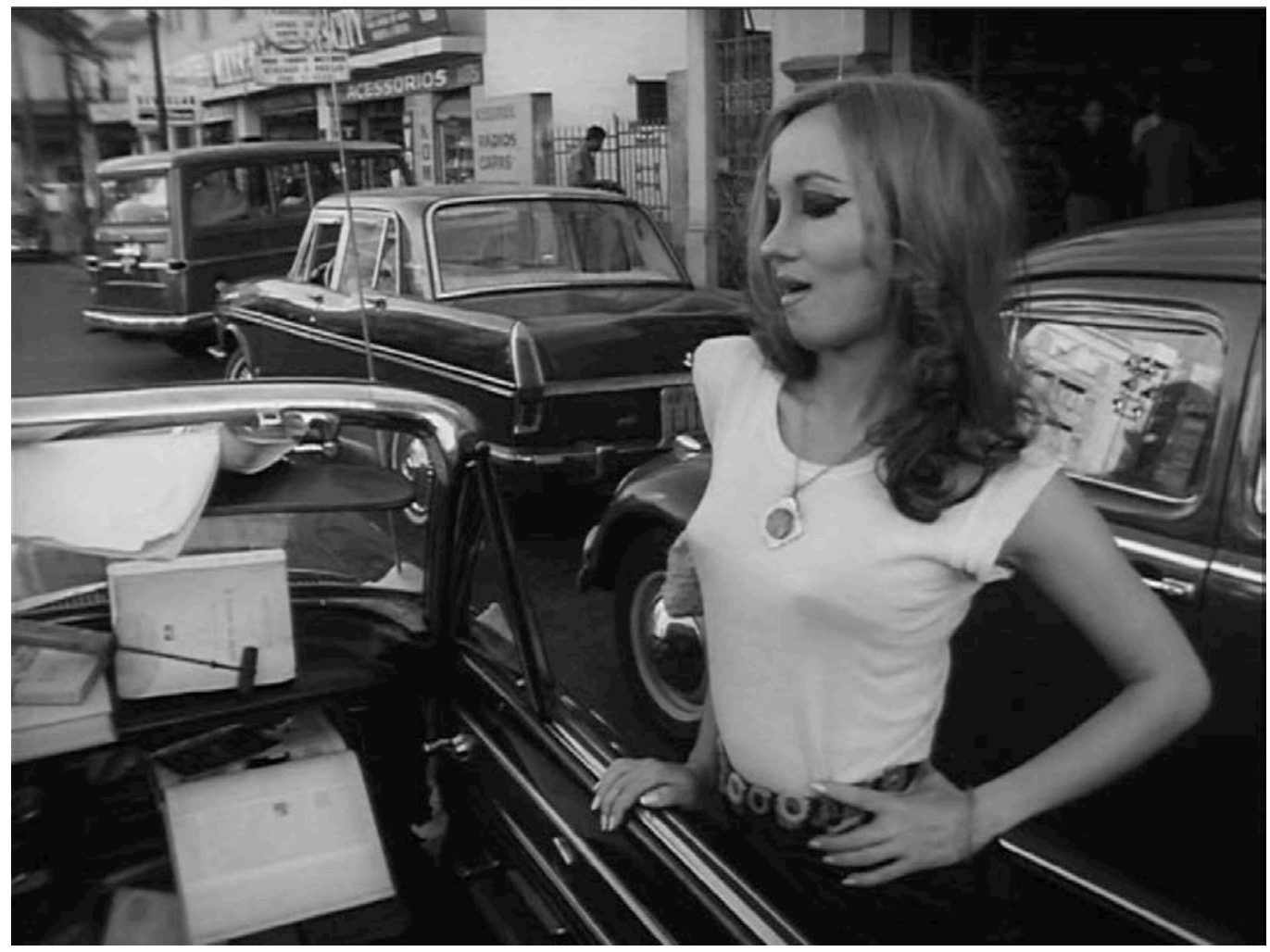

Fotograma do filme "O Bandido da Luz Vermelha"

Figura 82 - O Bandido e Jane na praia.

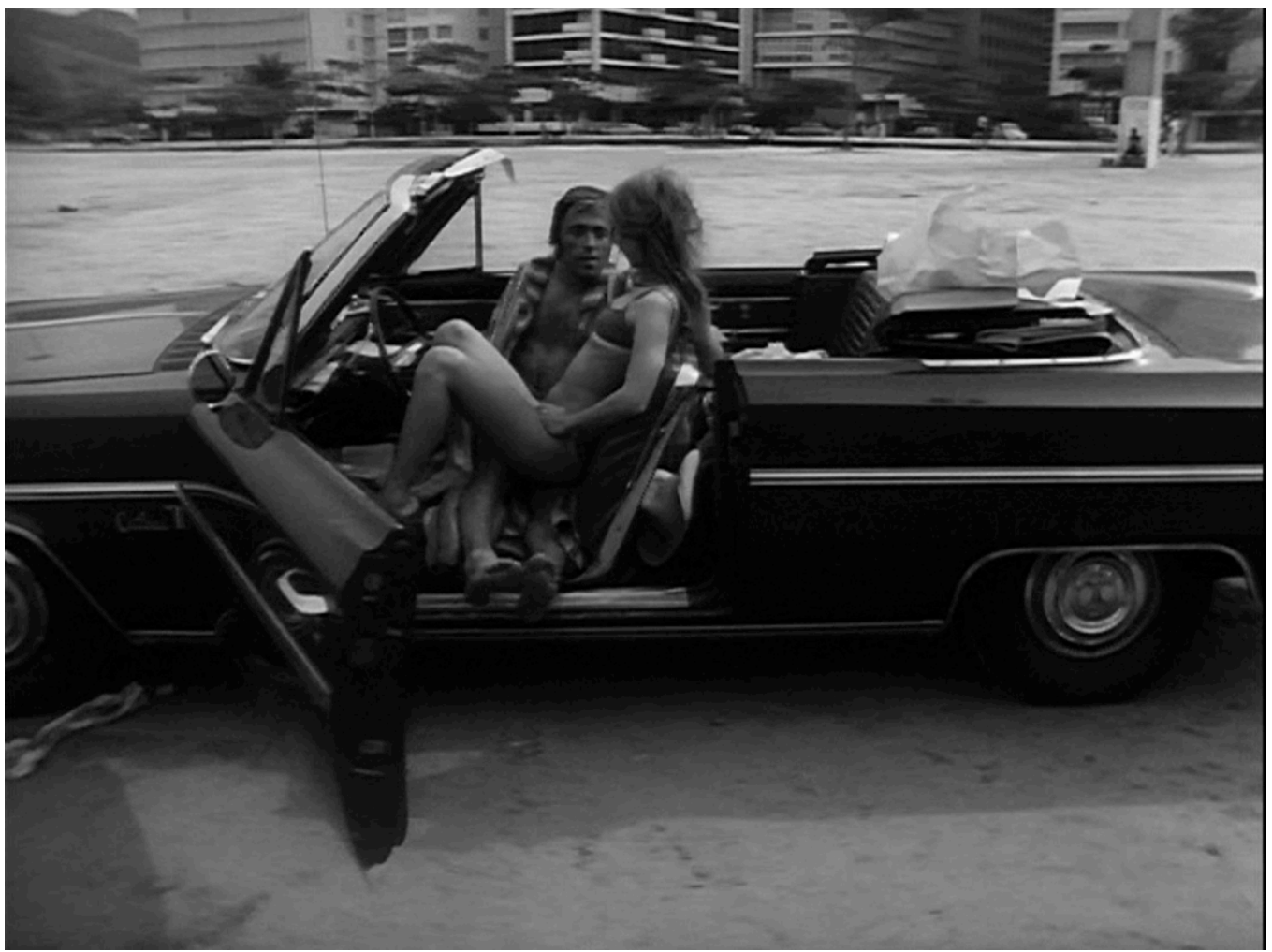

Fotograma do filme "O Bandido da Luz Vermelha" 
Figura 83 - O Bandido veste roupão listrado.

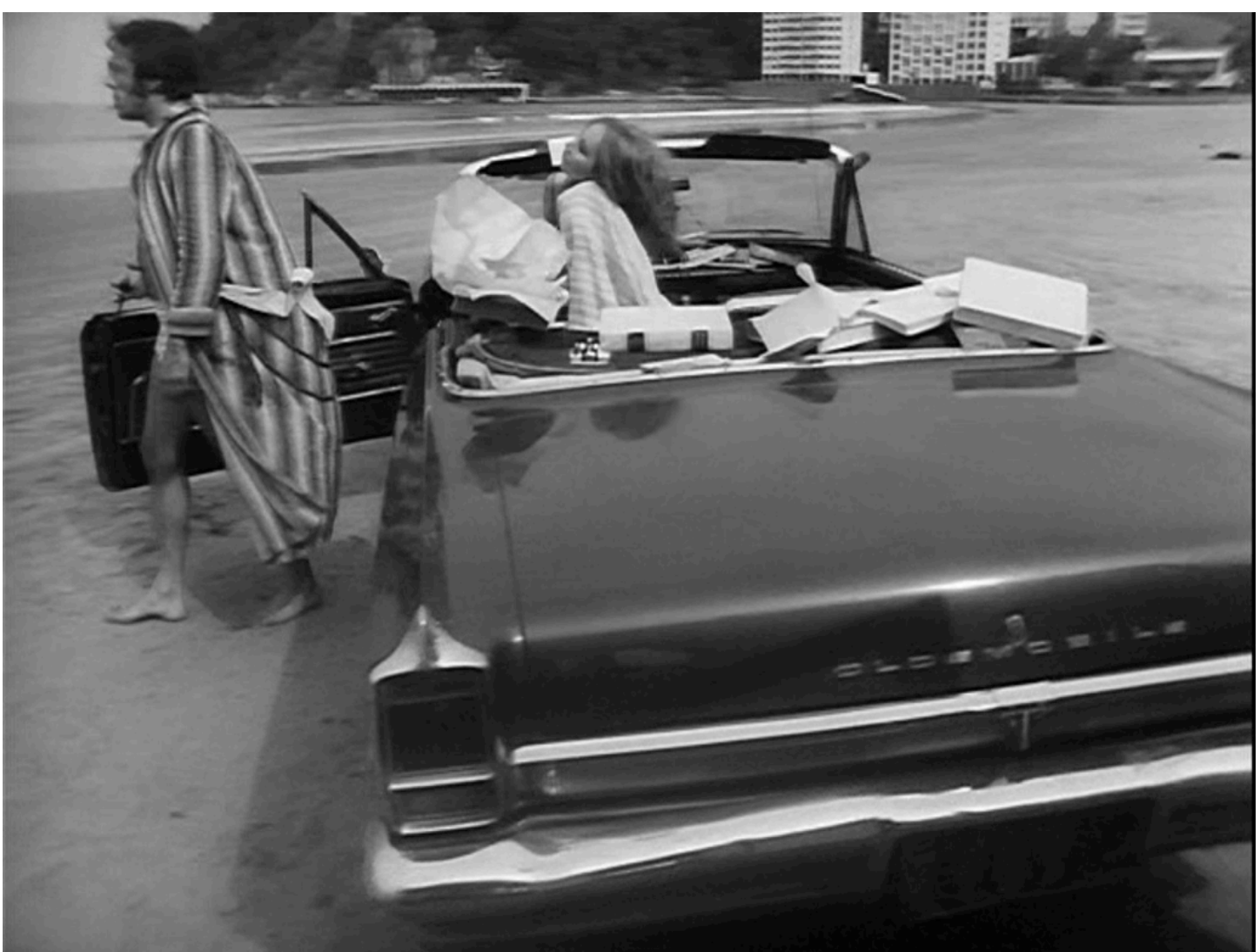

Fotograma do filme "O Bandido da Luz Vermelha"

As listras são elementos presentes no guarda-roupa do Bandido. Pode-se dizer que os padrões geométricos, inclusive as listras, parecem ter relação com o desejo de ordenar o universo de alguma maneira. As listras, por exemplo, frequentemente parecem expressar um desejo organizado, uma vontade ou capacidade de "seguir a linha" apresentada por si mesmo ou por outros. Por associações, podem sugerir segurança e retidão (LURIE, 1997). Talvez este fosse o desejo do protagonista.

Outra questão relevante nesta sequência é o uso do roupão felpudo na praia, tipo de vestimenta já usado pelo Bandido quando ele escrevia cartas. Os integrantes das classes sociais mais elevadas, dificilmente usam poucas roupas.

$\mathrm{Na}$ praia, embora os homens ricos mergulhem no mar em trajes tão escassos como os de qualquer um, assim que saem da água, correm a vestir o quimono de seda pura, o roupão felpudo ou a camisa de linho que combina com o calção e restabelece o status (LURIE, 1997, p.134). 
O uso desde item pelo Bandido revela sua vaidade, sua excentricidade, sua obsessão por vestimentas e acessórios. Inconscientemente, ou não, ele almeja pertencer à outra classe social, ele não quer parecer com um ser comum na praia.

O personagem central é fracassado e ao mesmo tempo destrutivo, não consegue agir. Fica evidente esta atitude quando o personagem diz a célebre frase: "Sozinho é ridículo, a gente não pode fazer nada. Quando não pode fazer nada, a gente avacalha, avacalha e se esculhamba", demonstrando impotência e degradação. Nesta cena, ele está dento do carro com Janete Jane e usa a mesma camiseta branca canelada do início do filme (figura 84). Outro elemento importante no gestual do Bandido é o cigarro. Muitos personagens na trama fumam cigarros, o que era muito comum nesta época.

Figura 84 - O Bandido diz a famosa frase: "Sozinho é ridículo, a gente não pode fazer nada. Quando não pode fazer nada, a gente avacalha, avacalha e se esculhamba".

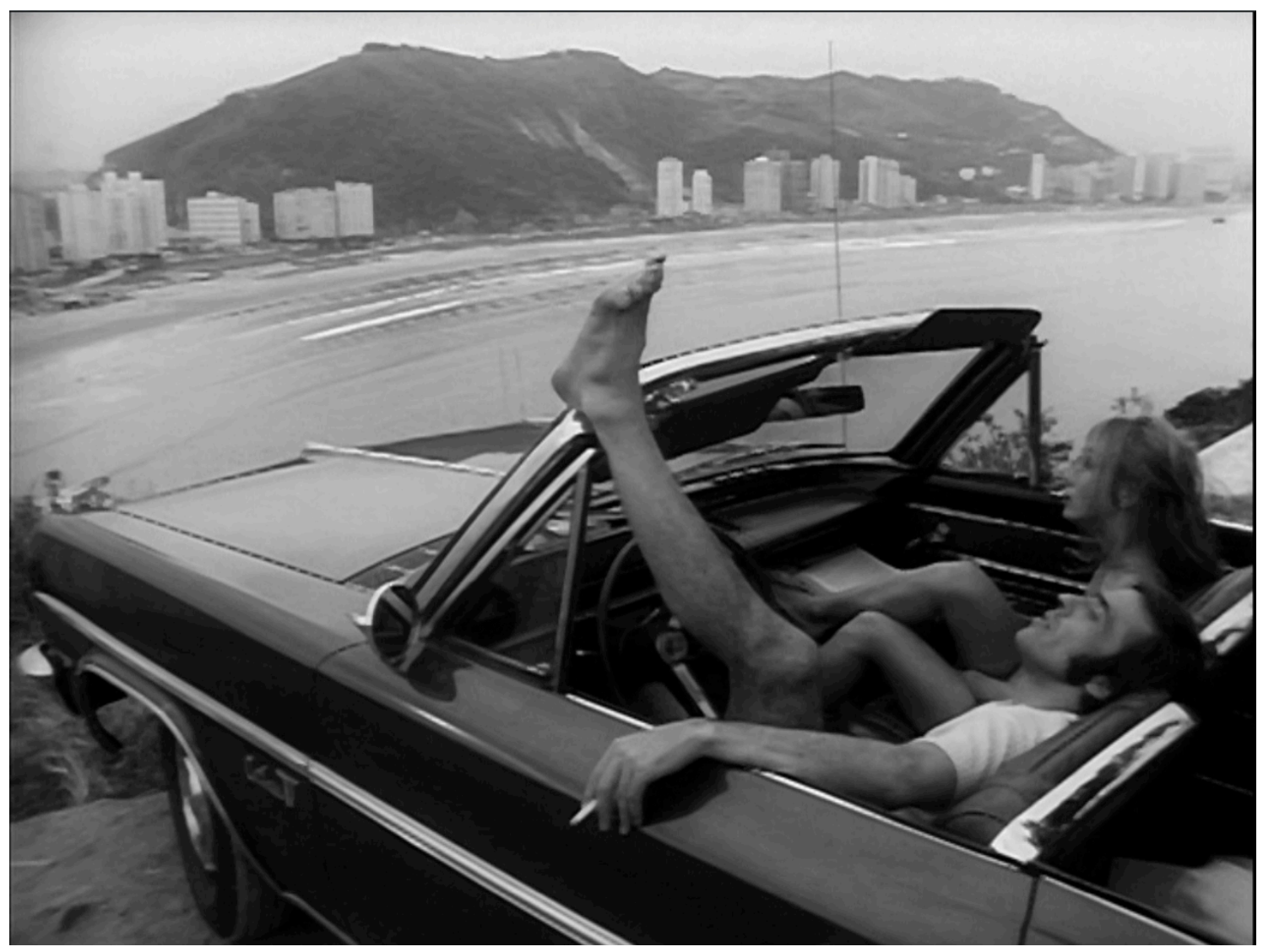

Fotograma do filme "O Bandido da Luz Vermelha"

No momento seguinte, o Bandido e Janete passeiam pela praia. Os dois namoram próximos do carro e num instante a amante faz menção de abrir o porta- 
malas. O Bandido afasta a moça e a impede de completar a ação, como se houvesse algum segredo no porta-malas que ela não pudesse ver. Janete Jane veste o biquíni em meio tom e o Bandido usa figurino claro, camiseta manga curta e calção. Ambos estão desprotegidos em relação ao vestuário e frágeis diante da cena (figura 85).

Figura 85 - Janete Jane tenta abrir o porta malas e o Bandido a impede.

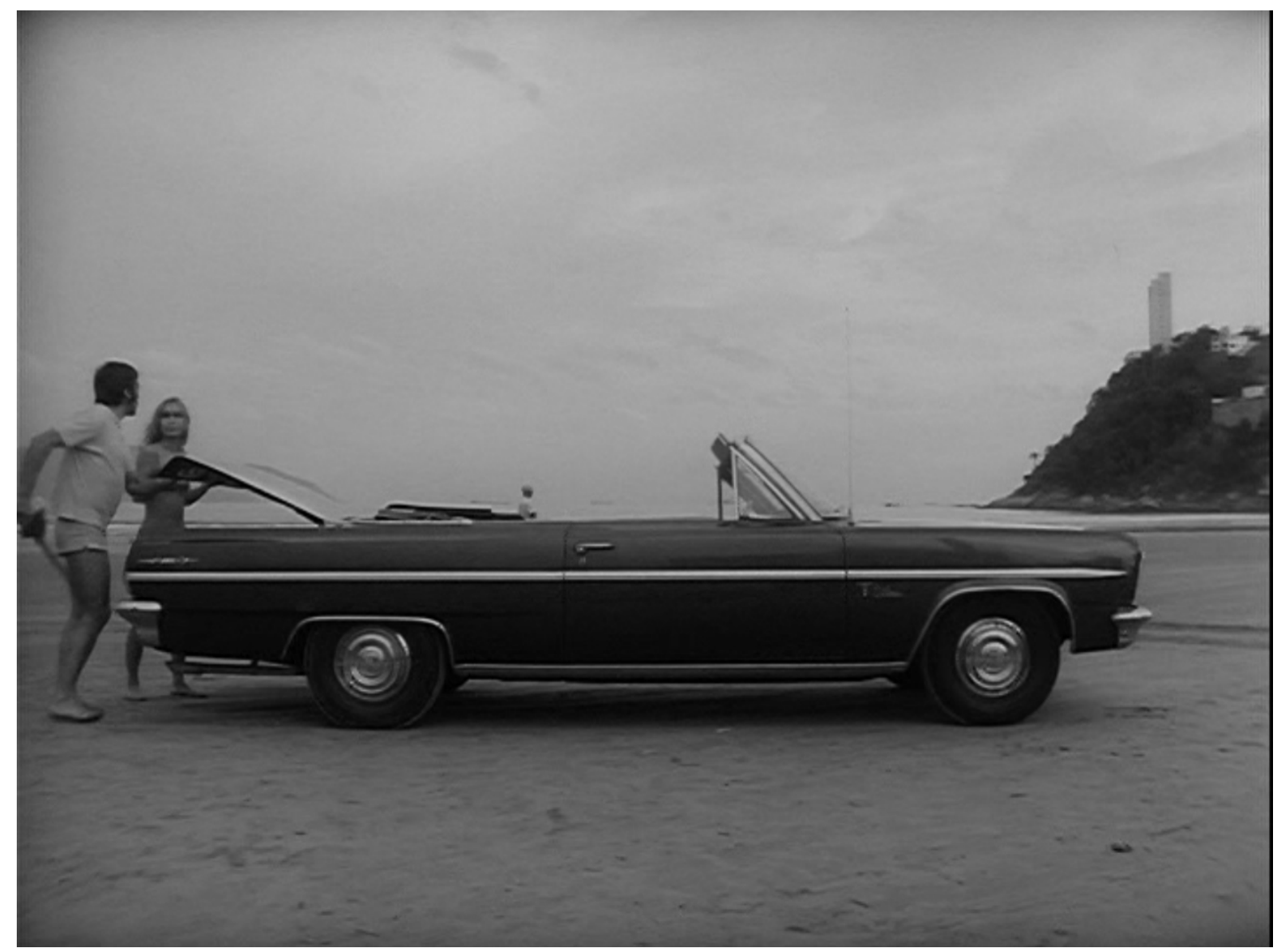

Fotograma do filme "O Bandido da Luz Vermelha"

O desejo de morte para o Bandido é contínuo. Numa das sequências ele espirra inseticida pelos ares e depois se joga no mar. Ele está elegantemente vestido com um paletó escuro, bem cortado, ombros no lugar, mangas com o comprimento correto, e uma camisa clara impecável. Seria um dos poucos momentos em que a roupa está exatamente do tamanho do ator. Um cachimbo completa a ação, como se ele fosse um bon vivant, vide figura 86.

Em seguida, ele se joga no mar e começa a boiar. Tentativa de suicídio frustrada, mais uma vez o herói fracassou. A camisa de tecido leve flutua na água, 
enquanto o paletó de um material pesado afunda, demonstrado na figura 87. Nesta cena é possível observar que o Bandido está descalço. Novamente o protagonista está vestido com trajes diferenciados da maioria das pessoas na praia, reforçando a ideia de que ele gostaria de recompor um status, de não ser um indivíduo comum.

O candidato J.B. Da Silva dá uma entrevista para uma emissora num estúdio de televisão. Seu figurino mantém o padrão de um político da época. Costume escuro e camisa branca. Porém nesta cena já temos indícios da extravagância deste personagem que usa uma gravata com motivo floral, descartando a ideia anteriormente concebida de se tratar de um homem tradicional, como pode ser visto na figura 88. O costume escuro tem peso, provavelmente é uma lã fria, que destaca com o fundo claro do quadro. A gravata estampada deixa o look harmonioso, porém inadequado para um político.

Figura 86 - O protagonista espirra inseticida pelos ares.

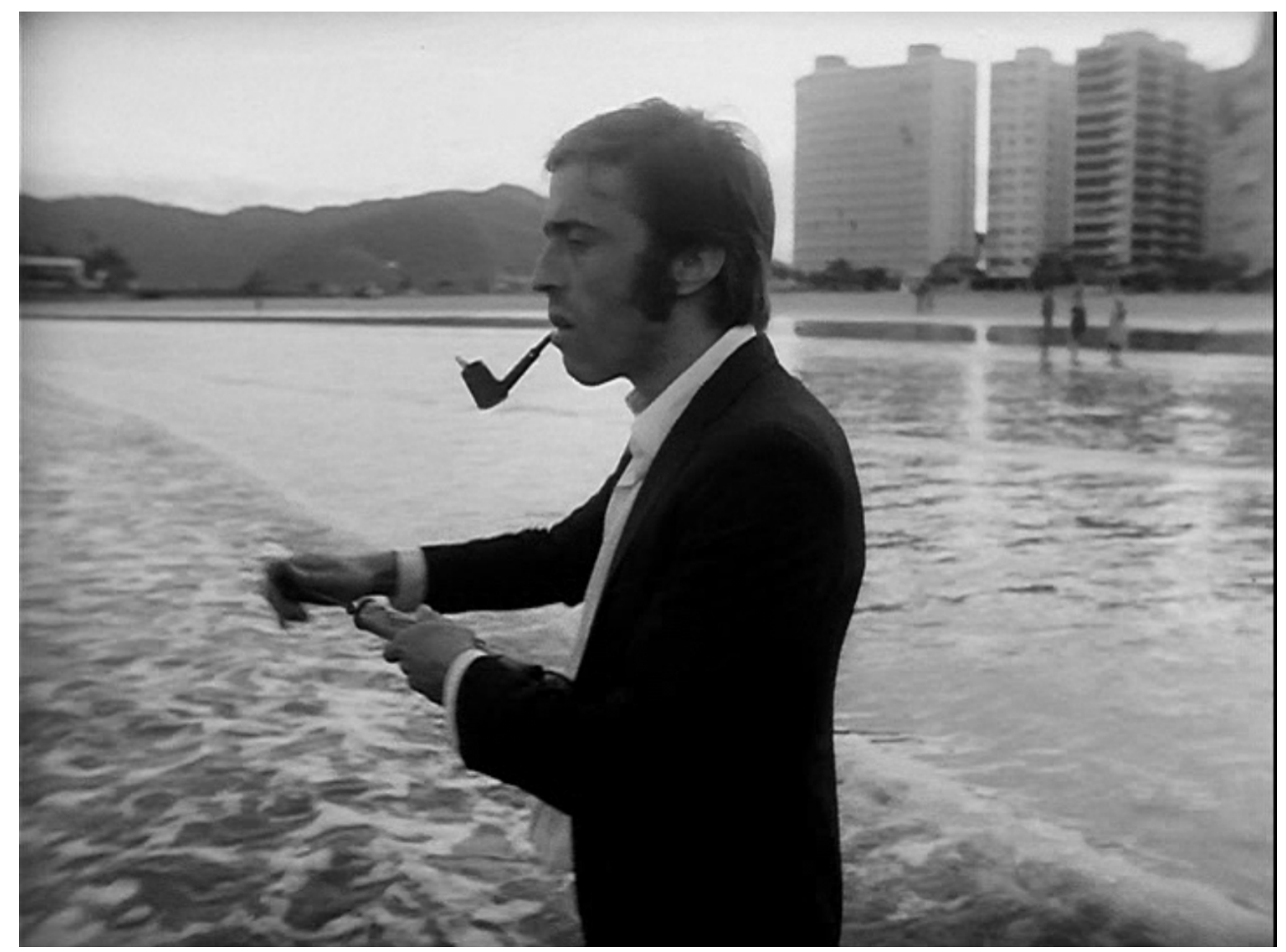

Fotograma do filme "O Bandido da Luz Vermelha" 
Figura 87 - O Bandido se joga no mar, numa tentativa de suicídio.

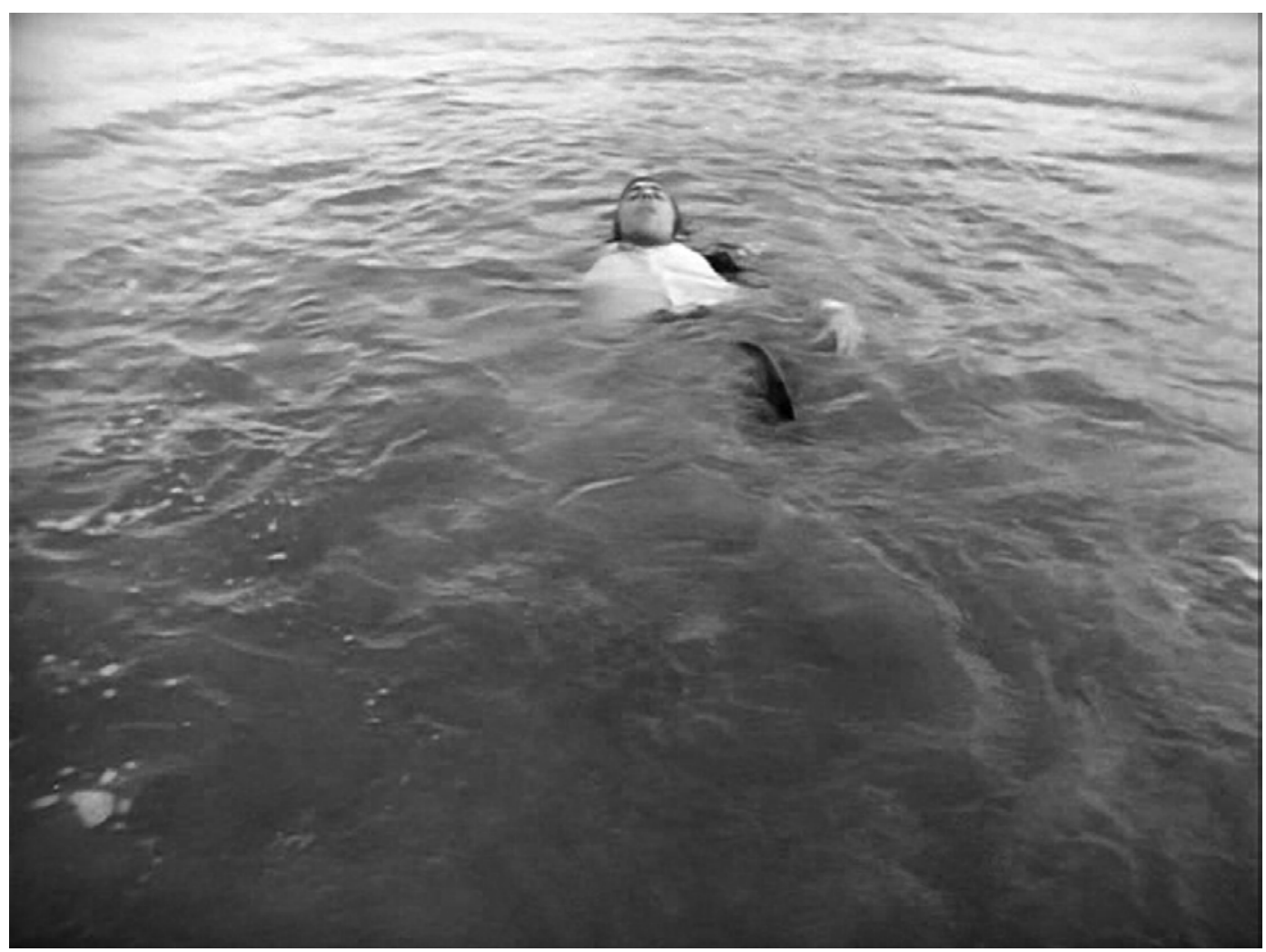

Fotograma do filme "O Bandido da Luz Vermelha"

Figura 88 - J.B. Da Silva dá entrevista em emissora de televisão.

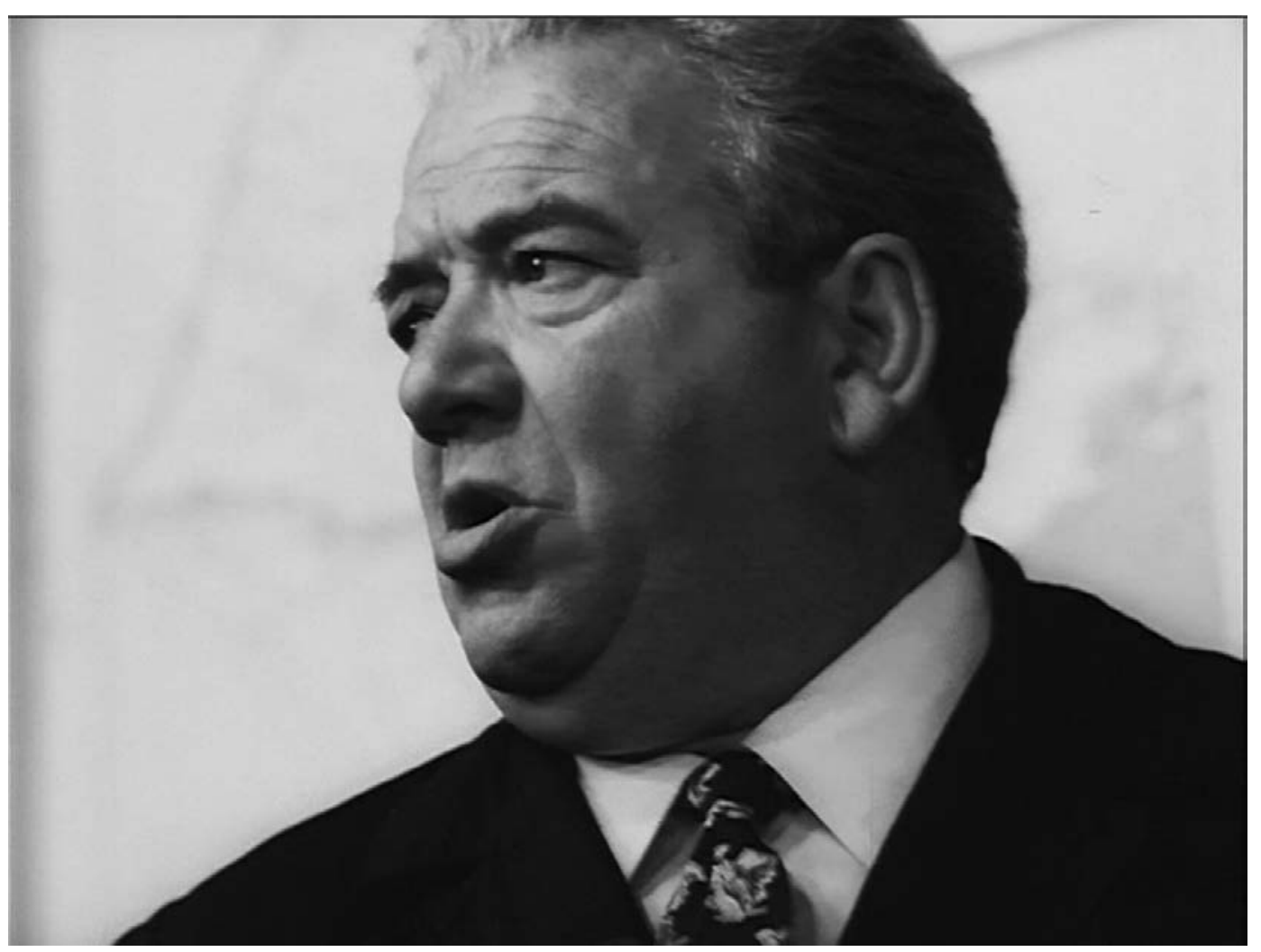

Fotograma do filme "O Bandido da Luz Vermelha" 
A amante do Bandido diz estar grávida e pede dinheiro para fazer um aborto. Ambos estão deitados na cama. Ela usa um soutien de renda escuro, peça do guarda-roupa de uma femme fatale para a época. O Bandido tem a camisa bicolor aberta, deixando o peito nu à mostra. Está com a calça de estampa de cobra e um cinto estampado, figura 89. O lençol claro destaca os figurinos.

Figura 89 - A amante dá a notícia da falsa gravidez ao Bandido.

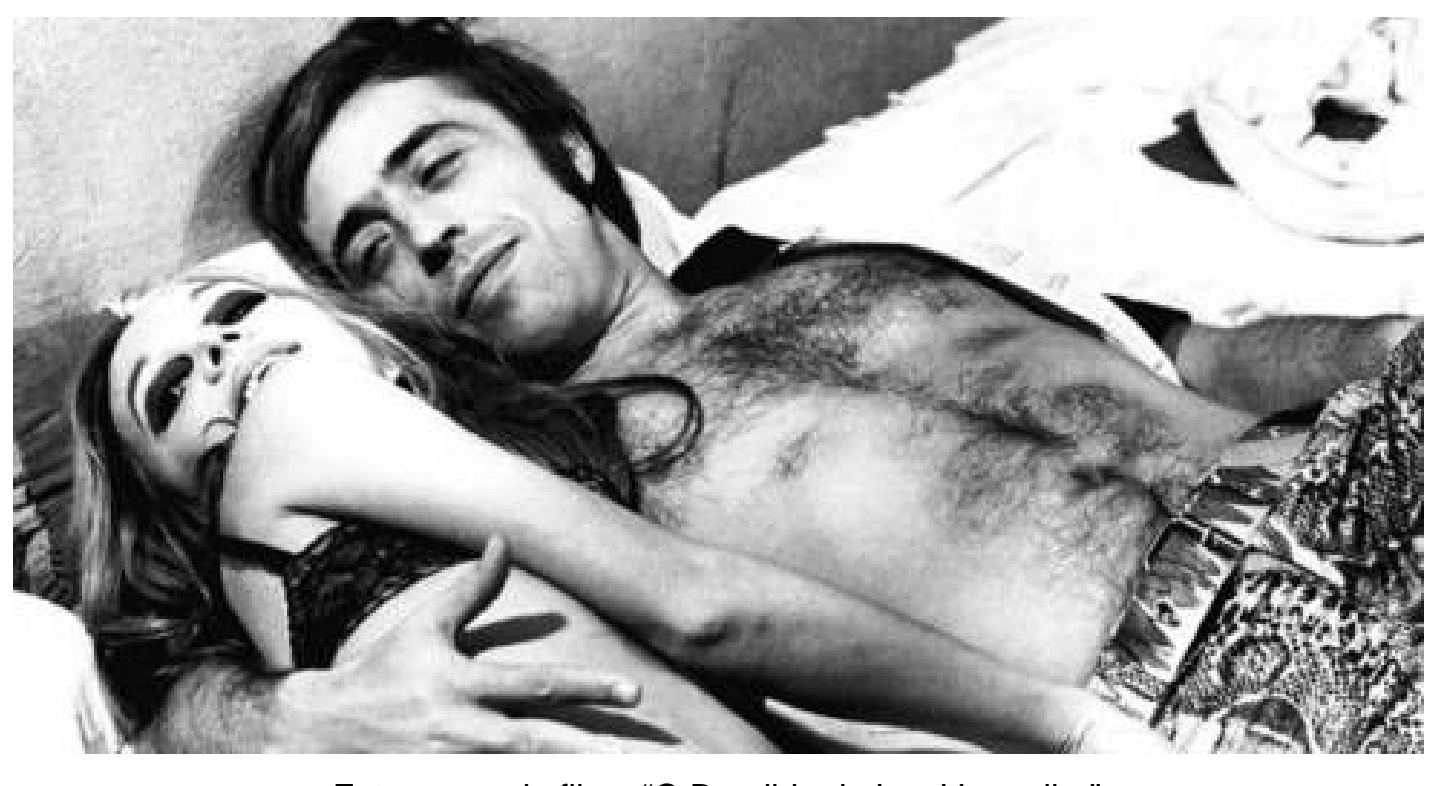

Fotograma do filme "O Bandido da Luz Vermelha"

Ao descer do apartamento do Bandido, Janete encontra seu cafetão Lucho Gatica, também conhecido como "mexicano", um dos capangas de J.B. Da Silva e Ihe entrega o dinheiro que recebeu do protagonista. Jorginho está na janela do seu quarto e percebe a traição quando vê sua amante oferecendo as notas ao gigolô. Jante Jane mantém seu figurino inicial. O figurino do cafetão é todo escuro como na sua primeira aparição, mas agora ele está vestido com um paletó e um casaco tipo sobretudo em lã escura jogado nas costas, peças de roupa fotografadas como preto. Muitas vezes, na história do cinema, os vilões aparecem de preto, assim como os feiticeiros, os magos e, na mitologia clássica, a própria Morte usa esta cor (LURIE, 1997). O gigolô usa óculos escuros, acessório presente no guarda-roupa de muitos personagens desta história. O sobretudo funciona como uma proteção, tem peso e não revela as formas do corpo. O figurino de Janete se opõe, pois é claro e transparente, o que sugere uma submissão, como pode-se observar na figura 90.

Nota-se a importância dos armários no imaginário do Bandido na cena onde ele e sua amante brigam. A briga acorre no quarto, logo após o protagonista ver 
Janete entregar o dinheiro, de um suposto aborto, ao cafetão. Quando o Bandido deixa o quarto, a primeira ação da amante Janete Jane é esmurrar a porta do armário, como se ela socasse o próprio Bandido. Posteriormente, ela tira as roupas do armário e espalha pelo chão, para depois pegar um terno e rasgar raivosamente. É como se ela dilacerasse o Bandido, apesar do personagem não ter se fixado em figurino algum. Em seguida, soca mais uma vez o guarda-roupa para depois entrar dentro dele e se fechar. Após esta sequência, o Bandido deixa de buscar roupas no armário ou experimentar roupas e acessórios.

Figura 90 - A amante entrega o dinheiro do Bandido para o cafetão Lucho Gatica.

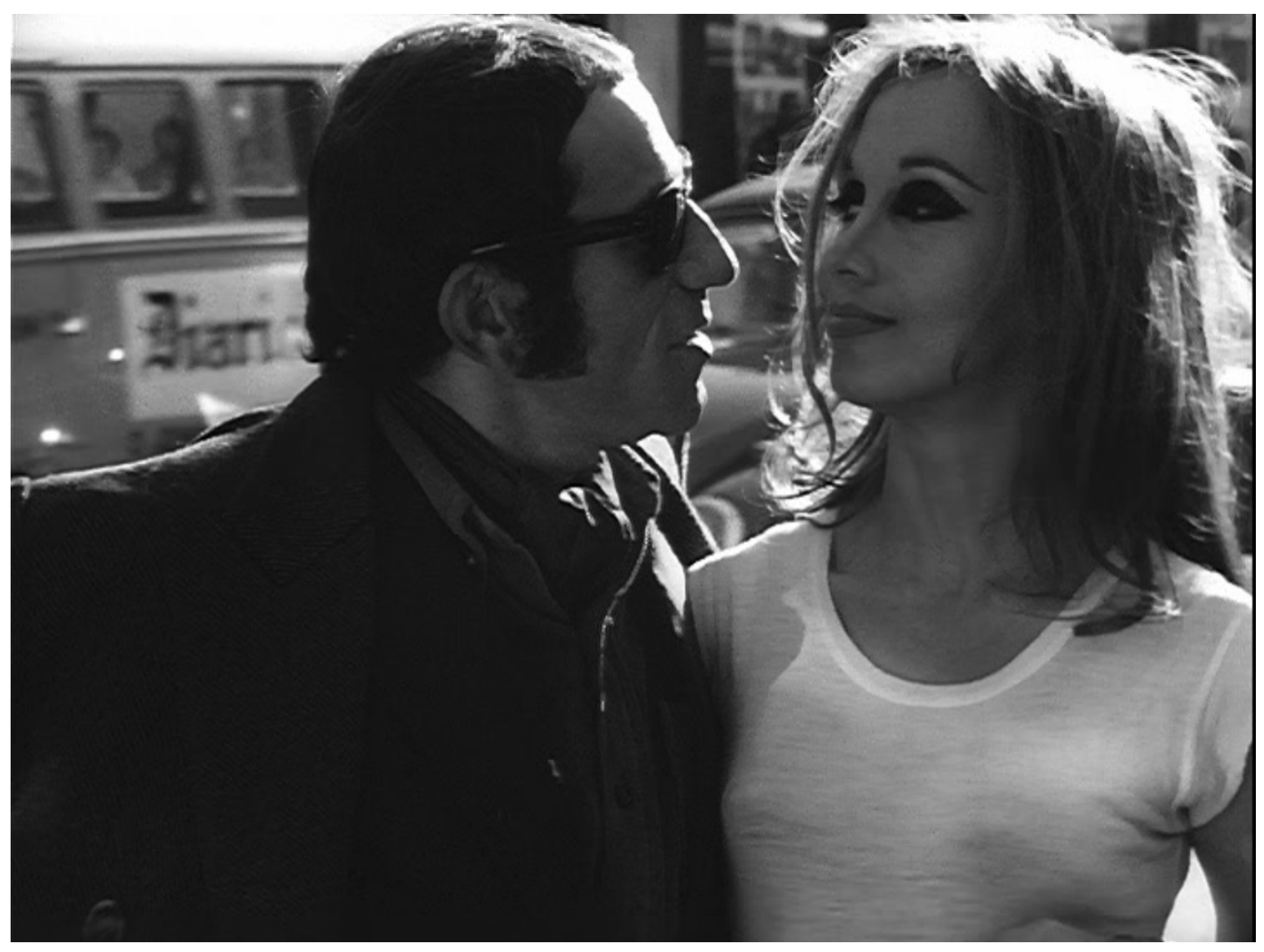

Fotograma do filme "O Bandido da Luz Vermelha"

Segundo Helena Ignez, o movimento da personagem ao rasgar as roupas do Bandido remetia a uma ação machista comum aos homens que picotavam as roupas das mulheres quando sentiam raiva, ou ciúmes, uma maneira de demonstrar autoridade (IGNEZ, 2015).

Conforme mencionado, o personagem central também tem um grande apego às malas cheias de quinquilharias, e no tampo interior das malas está escrito "EU", 
como se o interior fechado das malas pudesse substituir a interioridade que 0 Bandido não consegue elaborar (BERNADET, 1990).

A dimensão deste aspecto, o apego às malas, é evidenciado quando a amante do Bandido, Janete Jane, abre as malas do "EU" e espalha todo o seu conteúdo. Esta cena ocorre após a briga do casal no quarto do Bandido. Ela vai até o carro do Bandido, abre o porta-malas e começa a jogar todos os objetos das malas. Numa série de planos montados em descontinuidade com repetições e saltos, a personagem chama atenção para peças de roupas, rolos de papel higiênico, esteiras de praia, livros, a lata de inseticida, uma imagem de São Jorge entre outros objetos.

A amante usa o mesmo figurino contrastante que dá destaque ao espaço aberto onde ocorre a ação, com a cidade ao fundo. Durante a cena, existe um momento que é possível ver a calcinha da personagem, que também é clara (figura 91). O locutor em off anuncia que finalmente a amante descobre a verdadeira identidade do Bandido. Ao pegar o lenço de seda que ele cobria o rosto para fazer os assaltos, Janete Jane desvenda o mistério do Bandido da Luz Vermelha. É a partir da descoberta de um acessório do figurino do Bandido, que Janete Jane reconhece quem era o seu amante (figura 92).

Figura 91 - Janete Jane vasculha o porta-malas do carro do Bandido em busca da verdadeira identidade dele.

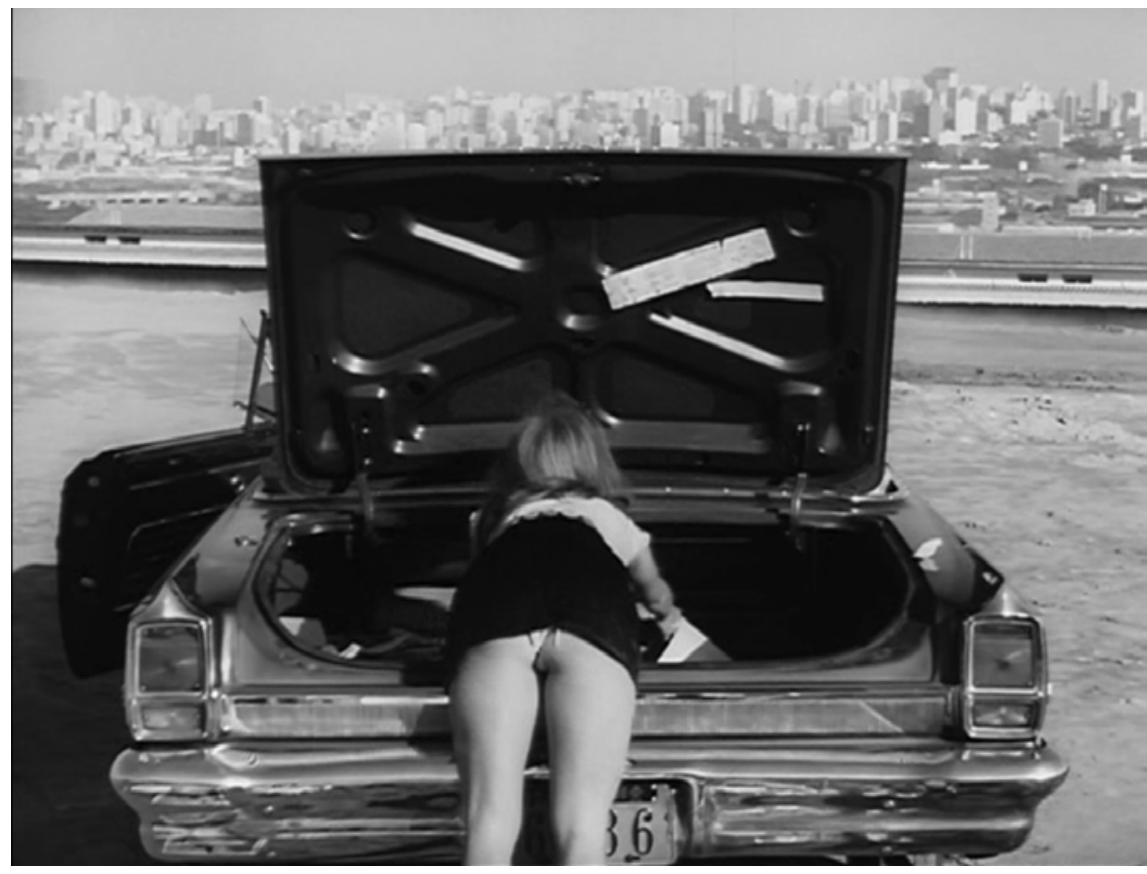

Fotograma do filme "O Bandido da Luz Vermelha" 
Figura 92 - Janete Jane descobre a identidade do Bandido.

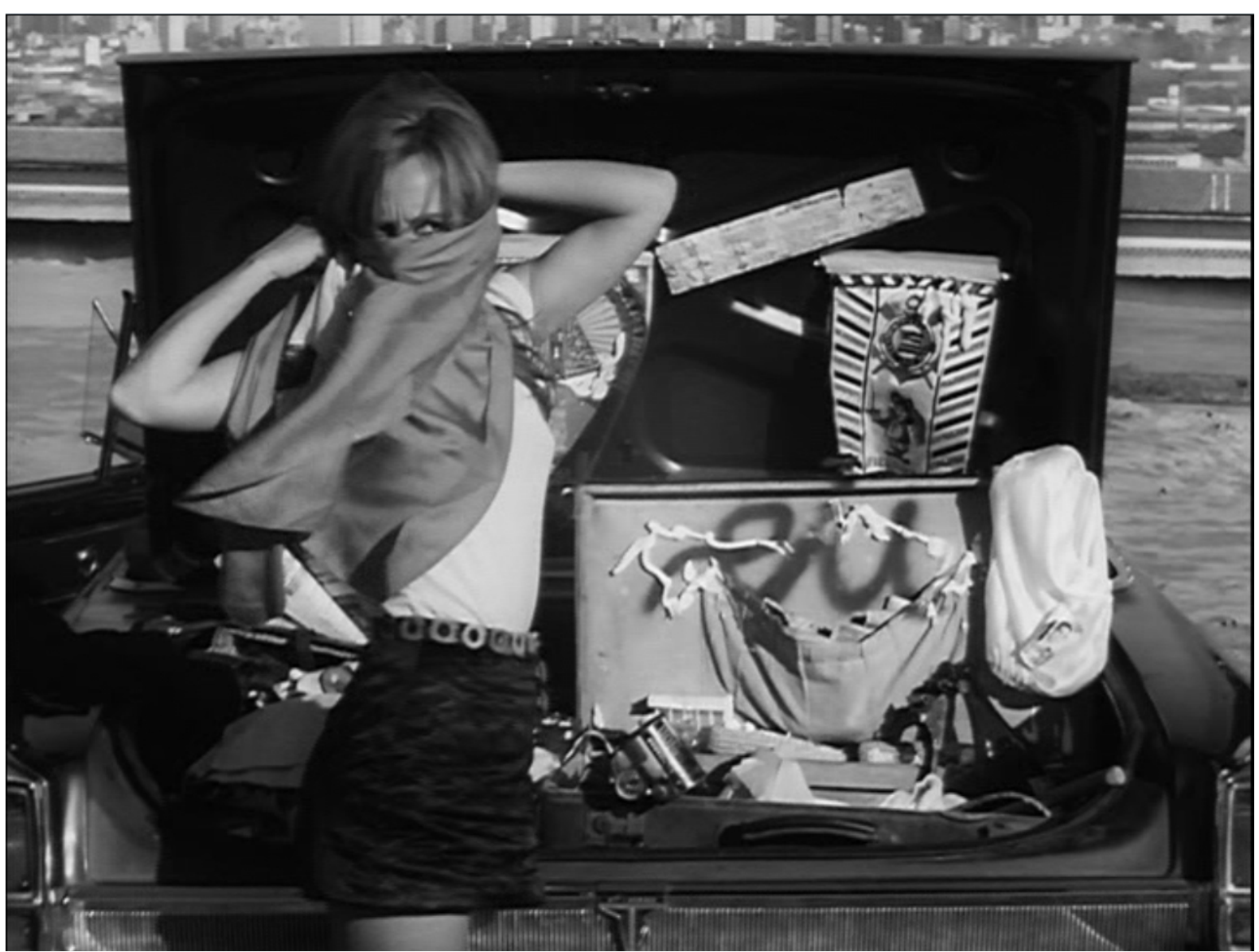

Fotograma do filme "O Bandido da Luz Vermelha"

Após algumas cenas onde o Bandido realiza diversas ações, com figurinos já descritos anteriormente, sequências sem continuidade, Janete Jane e Lucho Gatica aparecem jogando bilhar. Outra cena clássica do cinema americano. Ambos vestidos com o figurino inicial compõem o quadro de forma harmônica, tudo muito equilibrado e com a iluminação necessária para o clima da ação, observado na figura 93. O sobretudo jogado nas costas do cafetão tem peso e passa a ideia de proteção, enquanto a garota de programa, é suscetível à situação. A personagem fuma um cigarro.

Na fortaleza de J. B. Da Silva, é possível ver as relações entre Janete Jane e ele. A mulher fatal, sedutora, ambígua e infiel é a causadora da queda do herói. A relação de Jorginho, Janete Jane e J.B. Da Silva, o Rei da Boca, demonstra a afinidade de Sganzerla com a tradição noir. O candidato usa um robe de seda adamascado com gola e punho de veludo escuro, por baixo uma camisa de seda 
fundo escuro com estampa floral. As peças com volume indicam autoridade. Janete Jane conserva seu look. Uma figurante sentada no chão usa casaco de pele clara e boina escura. Este quadro apresenta vários elementos da riqueza, seda pura, veludo e pele de animal, vide figura 94. A câmera é alta, enquadramento do cinema clássico e segundo o próprio Rogério Sganzerla, como se fosse o olhar de Deus (SGANZERLA, 2001).

Após a descoberta de quem seria o verdadeiro Bandido da Luz Vermelha, a "fortaleza" do Luz é estourada, local onde ele habitava. Janete Jane e o Delegado Cabeção procuram pistas de onde estaria o Bandido. Nesta sequência, observa-se em frente ao imóvel a figura do cangaceiro em plena rua da cidade de São Paulo (figura 95), tendo ao fundo a música Asa Branca, detalhe que soma a ideia de "faroeste sobre o Terceiro Mundo". Para Xavier (1993), é a justaposição rural/urbana de O Bandido onde Glauber Rocha é referência. Helena Ignez diz em entrevista se recordar do momento em que Rogério Sganzerla coloca o chapéu de cangaceiro no personagem (IGNEZ, 2015).

Figura 93 - Janete Jane e Lucho Gatica jogam bilhar.

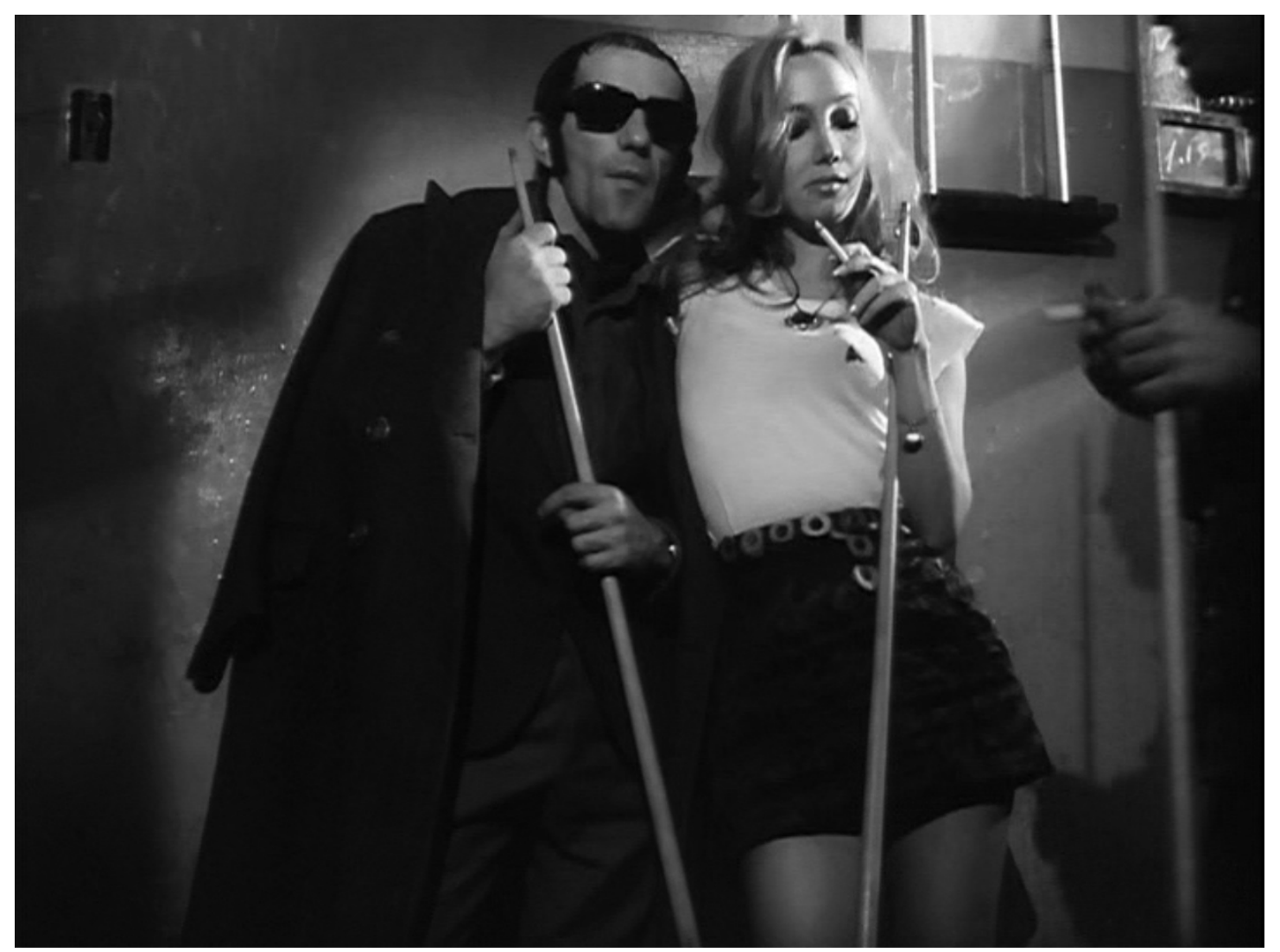

Fotograma do filme "O Bandido da Luz Vermelha" 
Figura 94 - Janete Jane na fortaleza de J. B. Da Silva.

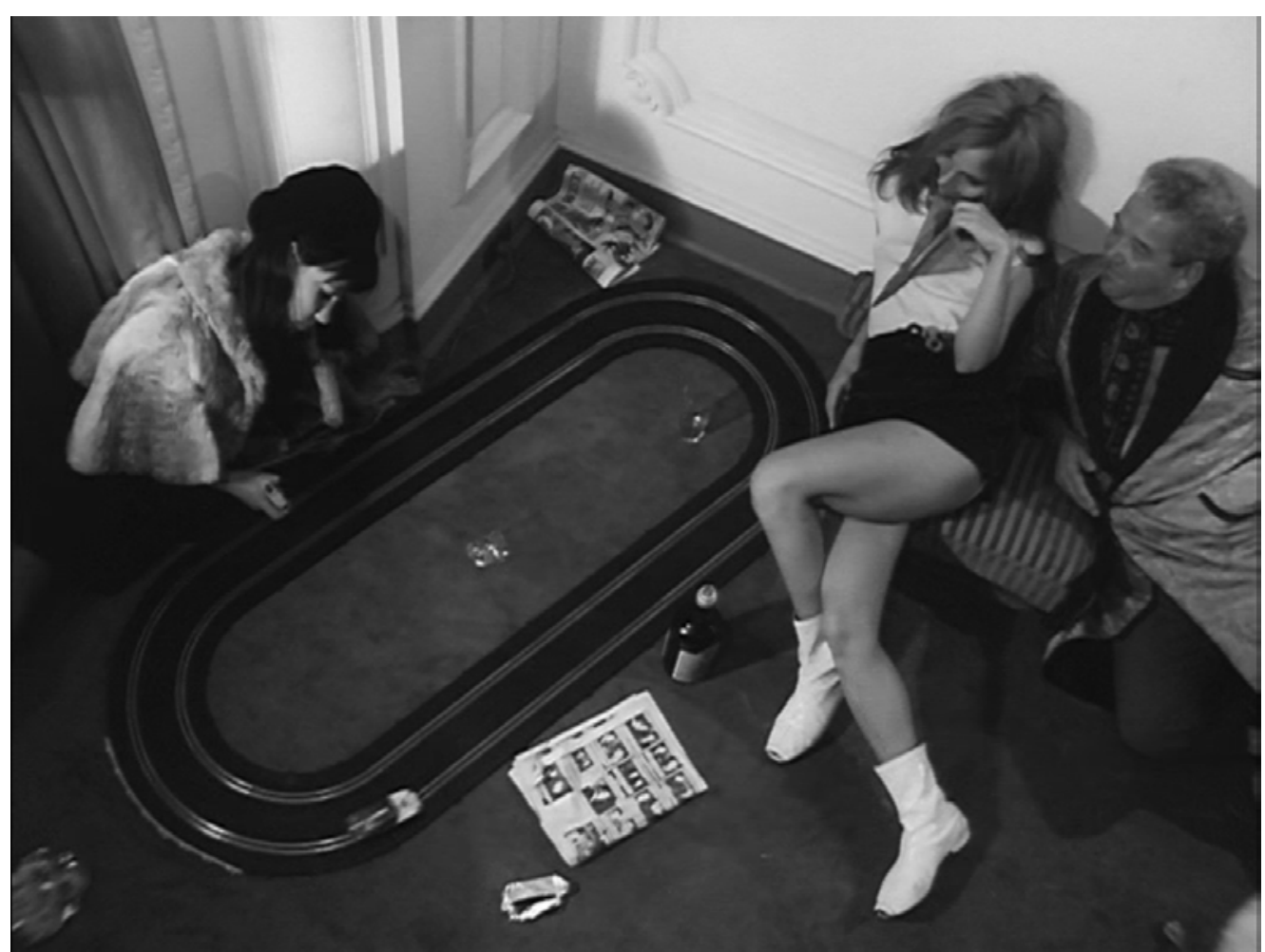

Fotograma do filme "O Bandido da Luz Vermelha"

Figura 95 - Cangaceiro em frente à "fortaleza" do Luz.

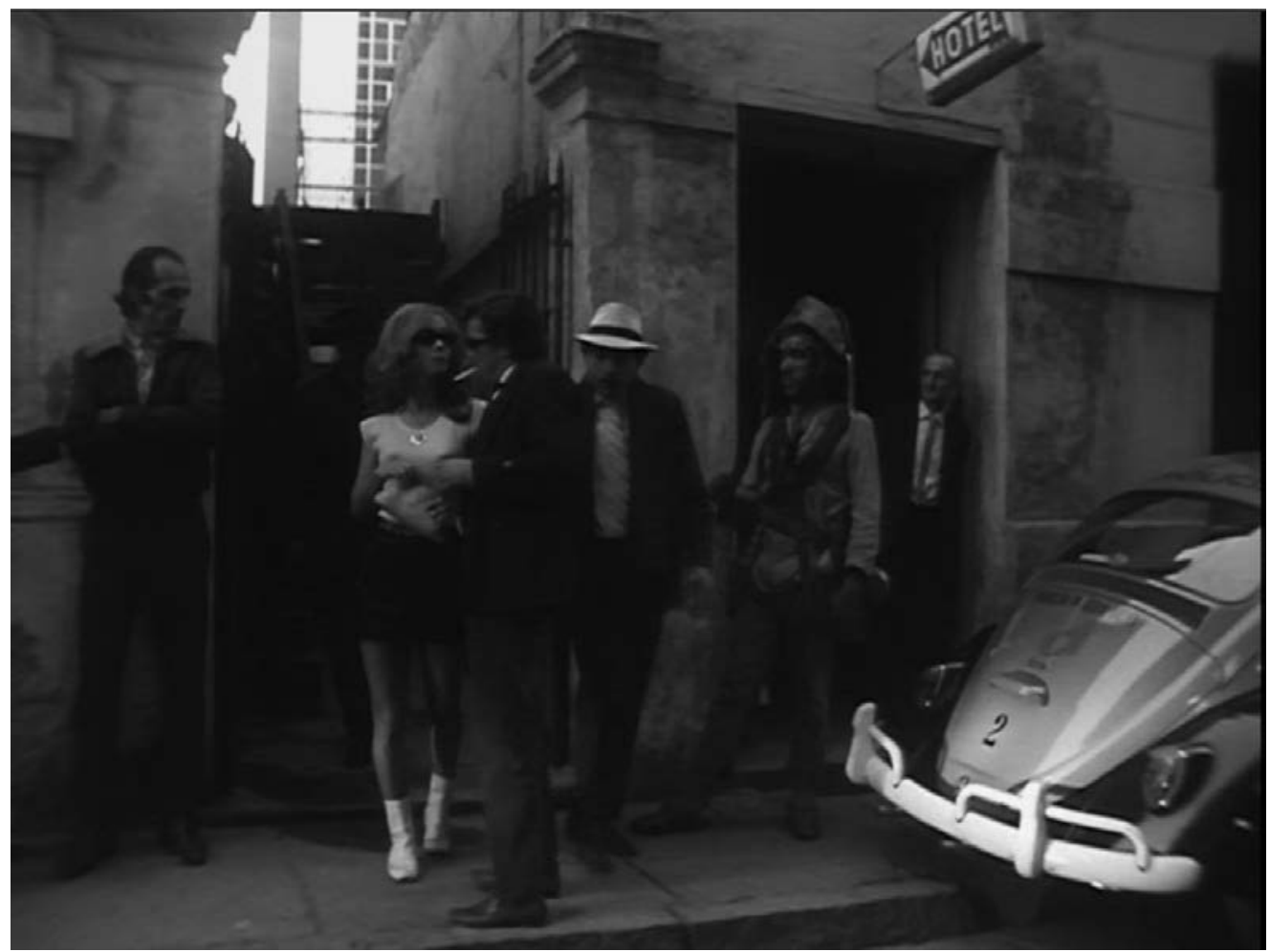

Fotograma do filme "O Bandido da Luz Vermelha" 
Em uma cena dentro do carro, J.B. Da Silva diz a frase sarcástica: "Um país sem pobreza é um país sem folclore. Sem folclore, o que vamos mostrar para o turista? Viva a pobreza!". Esta sentença é uma alegórica representação do coronelismo rural, somado ao malandro urbano, ao político brasileiro; além de remeter a notória expressão criada por Oswald de Andrade para denunciar a arte populista: "macumba para turista" (CANUTO, 2006). O político usa paletó em tom médio abotoado, possivelmente em shantung, com um foulard claro no pescoço. $O$ visual do político, um tanto quanto caricato, completa a frase do personagem que ironiza a situação do país, como pode ser visto na figura 96. Ao seu lado está um clássico personagem da Boca do Lixo, o Índio, usando figurino em tons escuros e com óculos escuros.

Figura 96 - J.B. Da Silva fala sobre a pobreza.

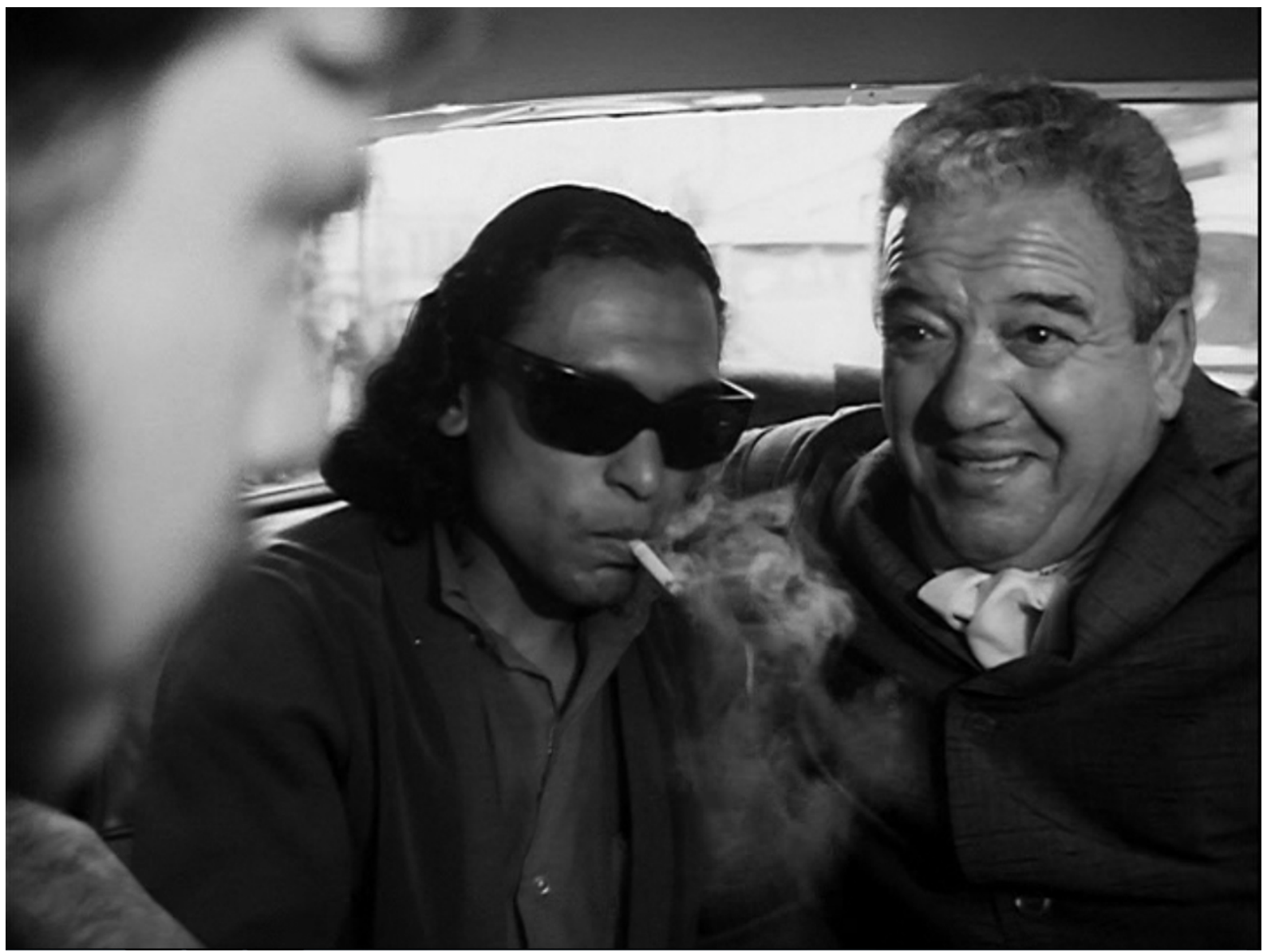

Fotograma do filme "O Bandido da Luz Vermelha"

Em sequência posterior, J. B. Da Silva caminha pelas ruas de São Paulo com seus assessores ao lado, entre eles Lucho Gatica, alguns jornalistas e eleitores. Ele 
usa o mesmo blazer da cena anterior com o foulard claro e completa o look com um chapéu panamá claro e um charuto. Sua calça e mocassim também são claros. Levando em consideração a convenção hollywoodiana, pode-se dizer que o chapéu claro tem a intenção de representar um "bom moço". Julio Calasso Junior comenta que o ator Pagano Sobrinho trouxe o figurino para interpretar o personagem. É possível notar que a roupa do candidato está bastante justa no ator, observada na figura 97 (CALASSO, 2015).

Figura 97 - J.B. Da Silva discursa nas ruas de São Paulo.

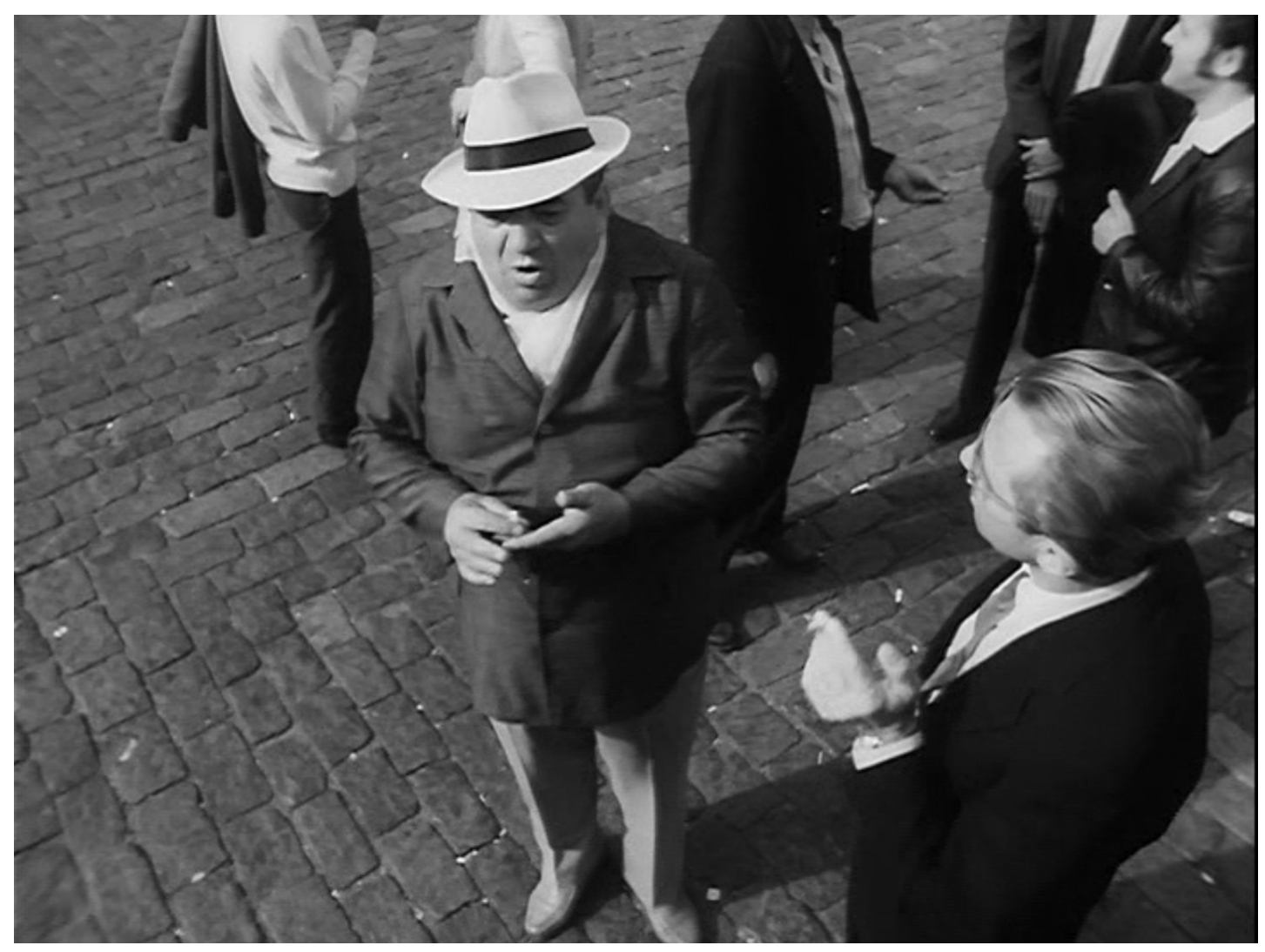

Fotograma do filme "O Bandido da Luz Vermelha"

O personagem J.B. Da Silva resume os traços de um populismo de direita, sustentado por clientelismo e negociatas, com referências ao político Adhemar de Barros. Para Ismail Xavier, o cenário da Boca do Lixo escancara a dimensão alegórica referida ao país. E ainda sua figura gorda remete ao Rei Momo, o Rei da Boca é o avesso da clandestinidade do Bandido da Luz Vermelha (XAVIER,1993).

Mais tarde, J.B. Da Silva será assassinado, com uma bomba que foi colocada em seu carro. Provavelmente uma mala bomba inserida no porta-malas do político pelo Bandido. Antes da morte de J.B. Da Silva, o Bandido prepara sua última 
bomba, como pode ser observado na figura 98. Enquanto o político está com Lucho Gatica numa boate cantando, Luz confecciona o explosivo. Nesta cena, o Bandido usa uma camisa clara com um jabot de renda, possivelmente branca, que tem as mangas dobradas simetricamente, traje usado pelos juízes nos tribunais. Este é mais um dos looks esquisitos do Bandido, sempre ironizando as situações e a sociedade. Carlos Ebert, em entrevista para esta pesquisa, cita que a camisa de jabot usada pelo Bandido foi comprada numa das lojas da Boca do Lixo (EBERT, 2013).

Figura 98 - O Bandido prepara sua última bomba.

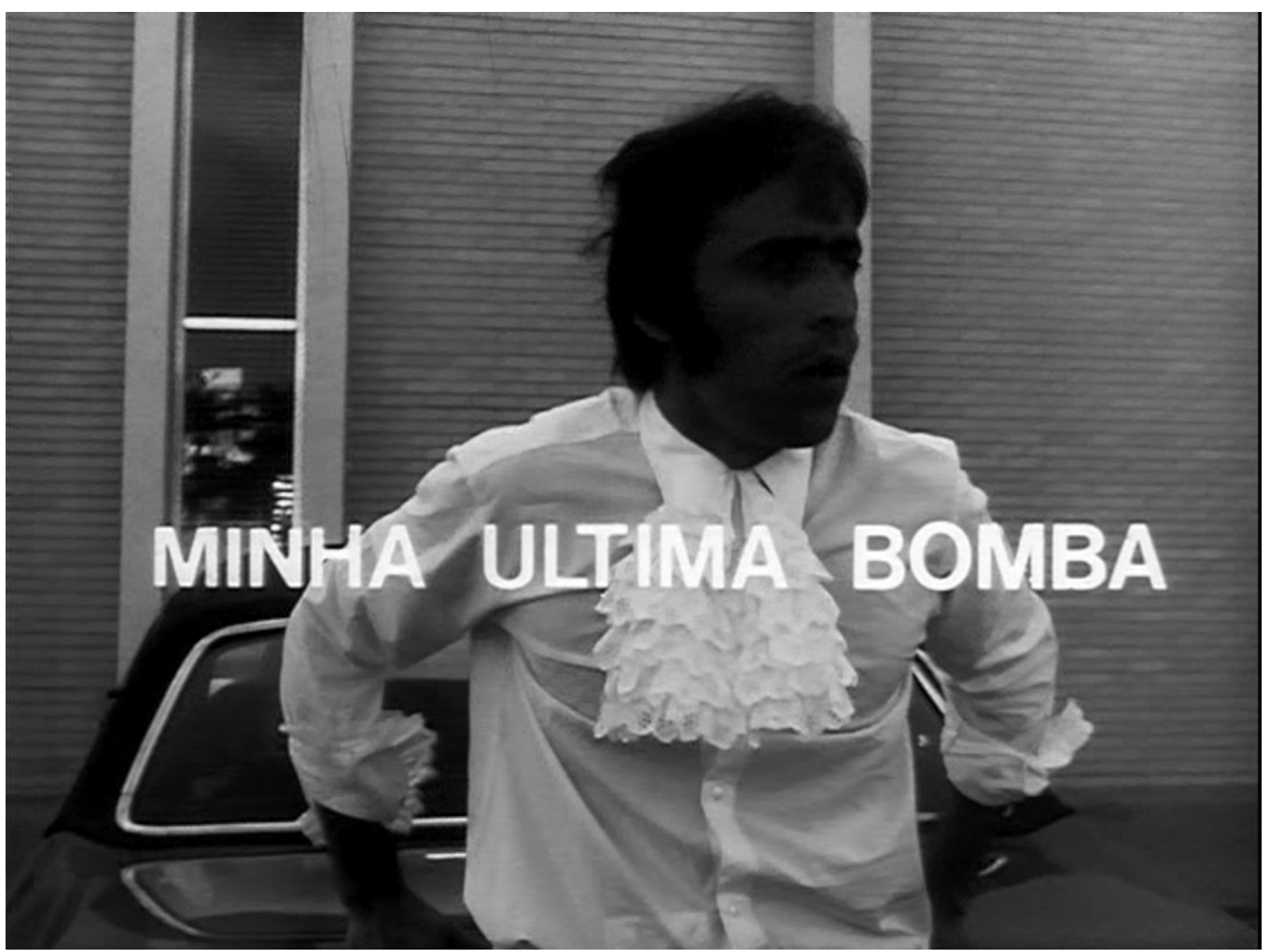

Fotograma do filme "O Bandido da Luz Vermelha"

Existem ações onde o Bandido não se volta para um ponto preciso, e espalha-se pelo todo. Uma delas é quando ele assassina sua amante com um tiro na barriga e em seguida, segurando o corpo de Janete Jane que caiu sobre o seu, dá um tiro em direção oposta ao corpo dela (figura 99). Janete Jane veste a camiseta clara combinada com minissaia escura e botas brancas, look já descrito 
anteriormente. Após ser assassinada, ela fica caída no chão e o sangue se espalha por seu corpo. A cor clara da camiseta destaca o contraste das manchas de sangue, acentuando a dramaticidade da cena (figura 100). O Bandido veste camiseta manga longa clara casada com um blazer em couro escuro, calça alfaiataria em meio tom, botas escuras e chapéu escuro com abas largas e debrum claro. O blazer em couro dá um brilho na tela para a cena noturna, conferindo um peso que garante segurança ao personagem para dar o tiro certeiro.

Figura 99 - O Bandido assassina Janete Jane.

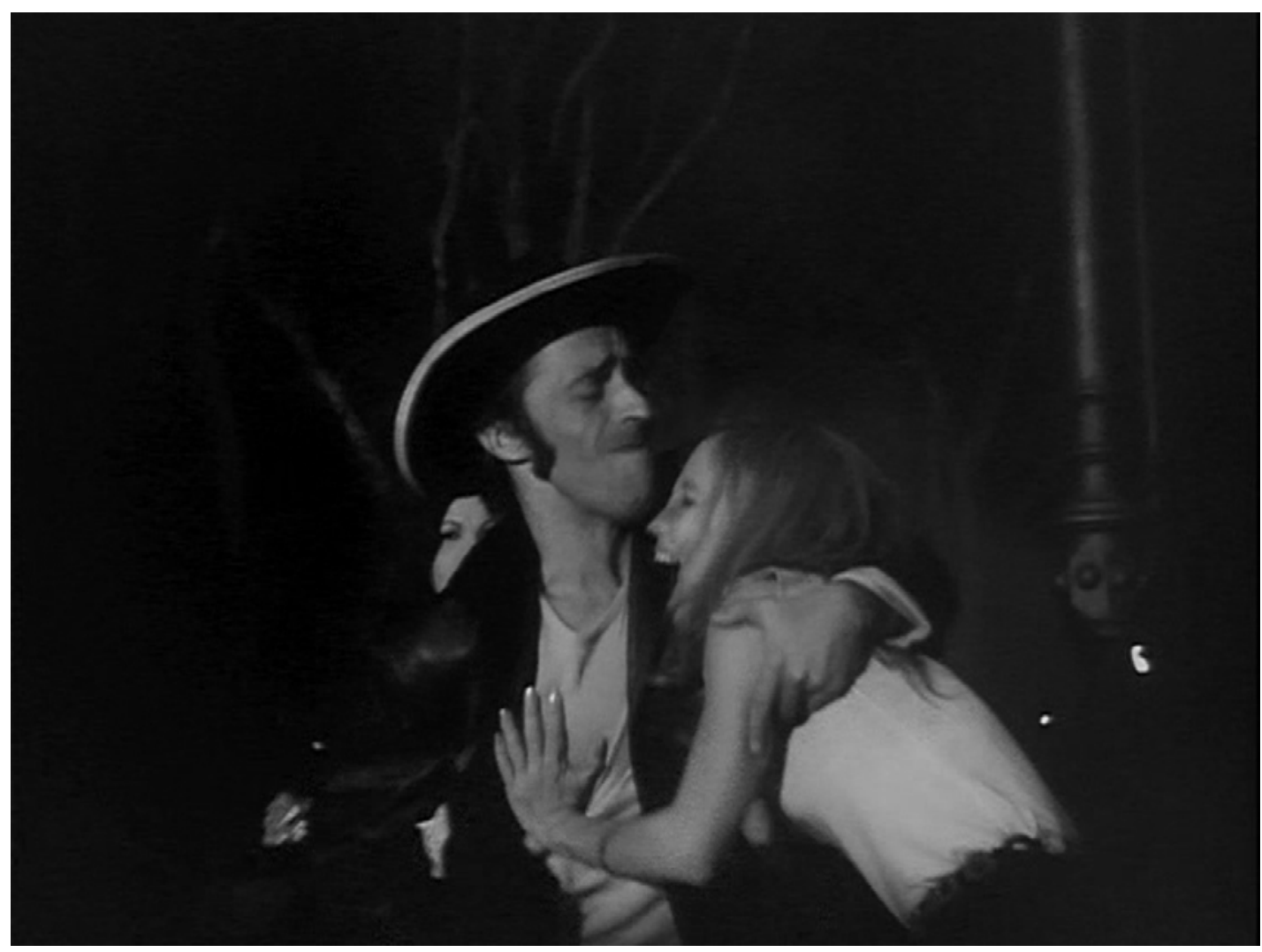

Fotograma do filme "O Bandido da Luz Vermelha"

A vitória é comemorada pelos fogos que uma prostituta triste faz pipocar em volta do cadáver da amiga Janete Jane. A prostituta usa um minivestido claro, sem mangas, em tecido com textura, uma renda. $O$ vestido tem um laço centralizado no decote. A personagem usa meias sete oitavos, de onde tira os fogos para acender, com botas escuras cano alto (figura 101) Em seguida, com os fogos acesos, ela caminha em volta do corpo de Janete como mostra a figura 102. A morte é celebrada com figurino claro, doce, ingênuo, totalmente contrário à situação violenta. 
Figura 100- O corpo de Janete Jane estendido no chão, ensanguentado após o tiro.

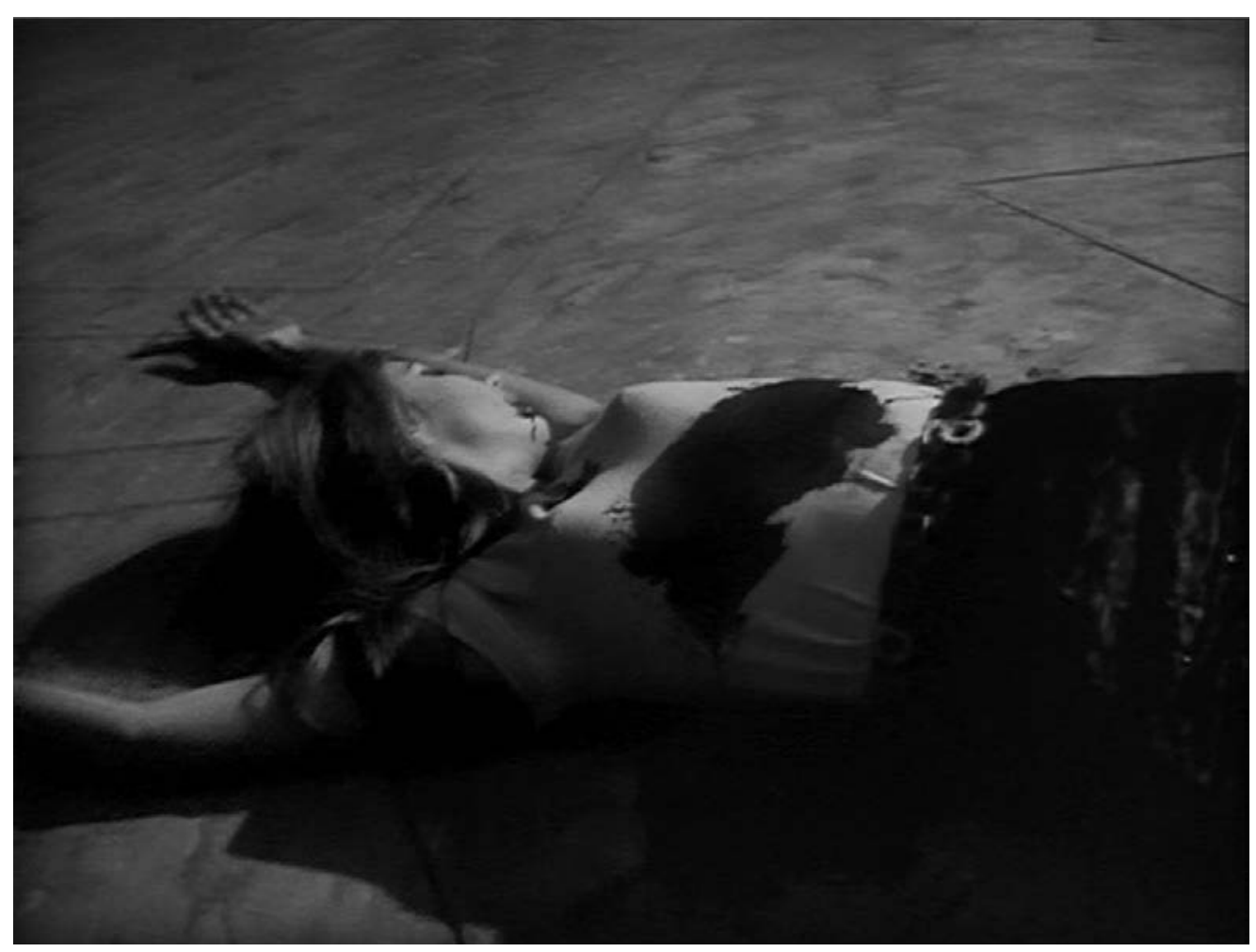

Fotograma do filme "O Bandido da Luz Vermelha"

Figura 101 - A prostituta amiga de Jane tira os fogos da cinta-liga.

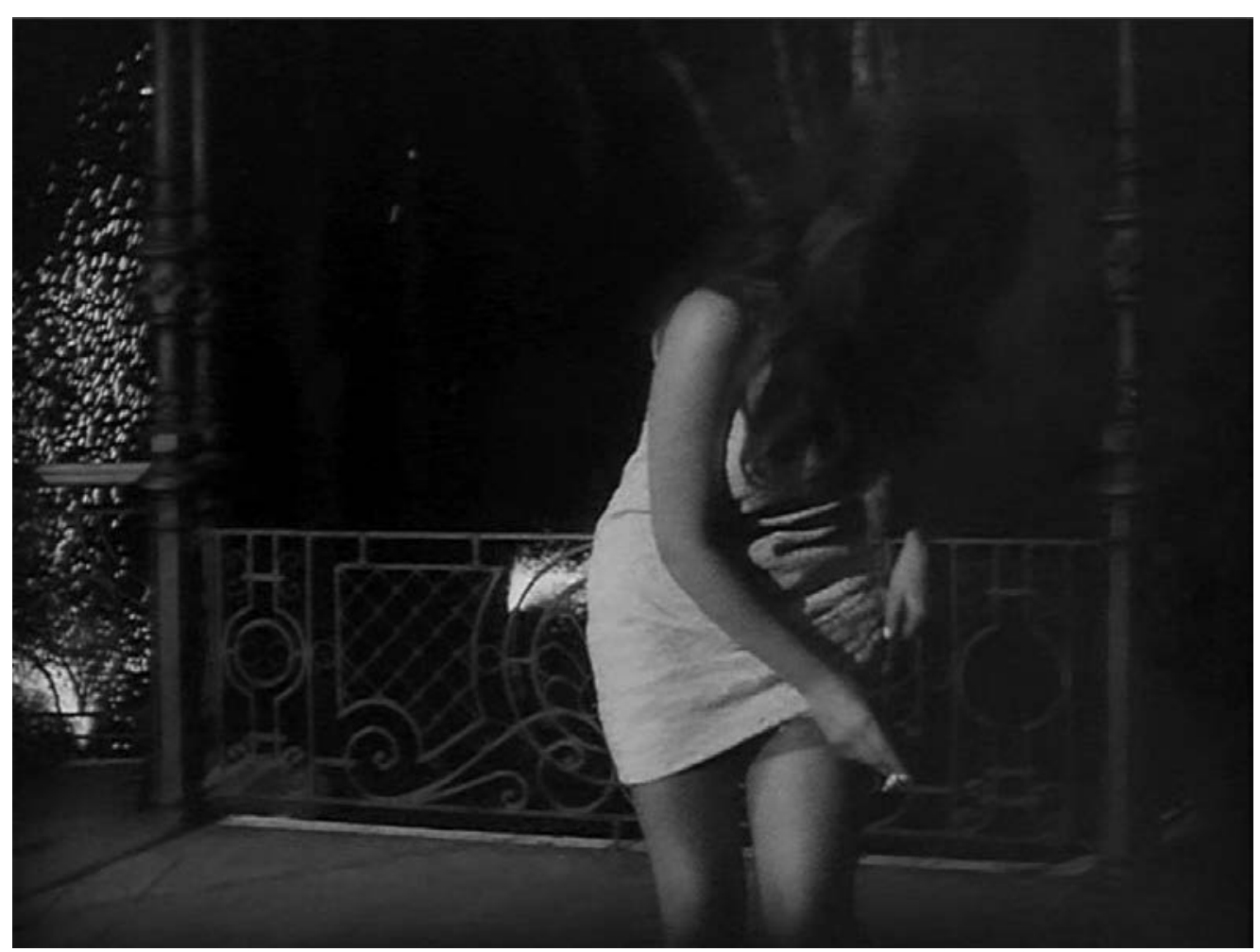

Fotograma do filme "O Bandido da Luz Vermelha" 
Figura 102 - A prostituta caminha ao lado do corpo de Janete Jane.

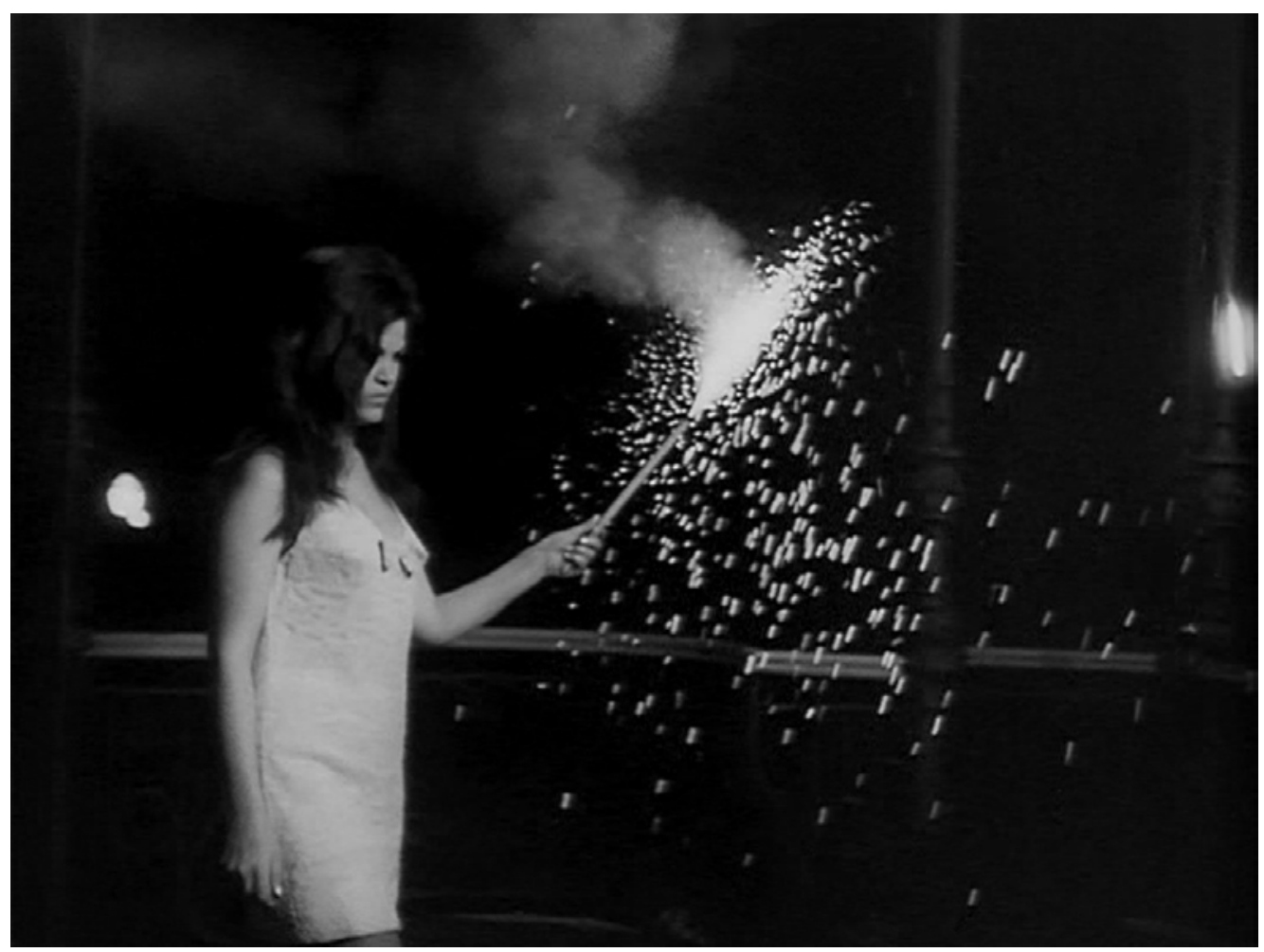

Fotograma do filme "O Bandido da Luz Vermelha"

Em seguida, à luz do dia, o Bandido aparece correndo por um parque girando dois fogos de artifício com as mãos. Usa uma camisa clara em tecido leve, manga longa, com os punhos abotoados. A camisa está por dentro da calça, que é escura e estreita, o cinto também é escuro O chapéu escuro com debrum claro é o mesmo usado pelo personagem em outras cenas. O figurino é regular e com contraste. $O$ ator inicia a cena dando risada, mas aos poucos vai mudando a fisionomia até ficar desolado, como mostra a figura 103.

Existe uma cena onde o Bandido sai da sala de cinema e vê seu retrato falado exibido num jornal. Neste momento, enfatiza seu lado narcisista ao falar: "Até que tá bacana!". E continua com sua postura destrutiva: "Acho que agora tudo isso vai acabar". Ele veste camisa clara manga longa, colarinho impecável, em tecido leve, combinada com blazer de couro escuro. Figurino com contraste e peso, mostrado na figura 104. O gesto de tragar o cigarro demonstra o desdém do protagonista. O fim do personagem está próximo, em breve ele se encaminhará para o suicídio. 
Figura 103 - O Bandido corre com fogos de artifício após a morte da amante.

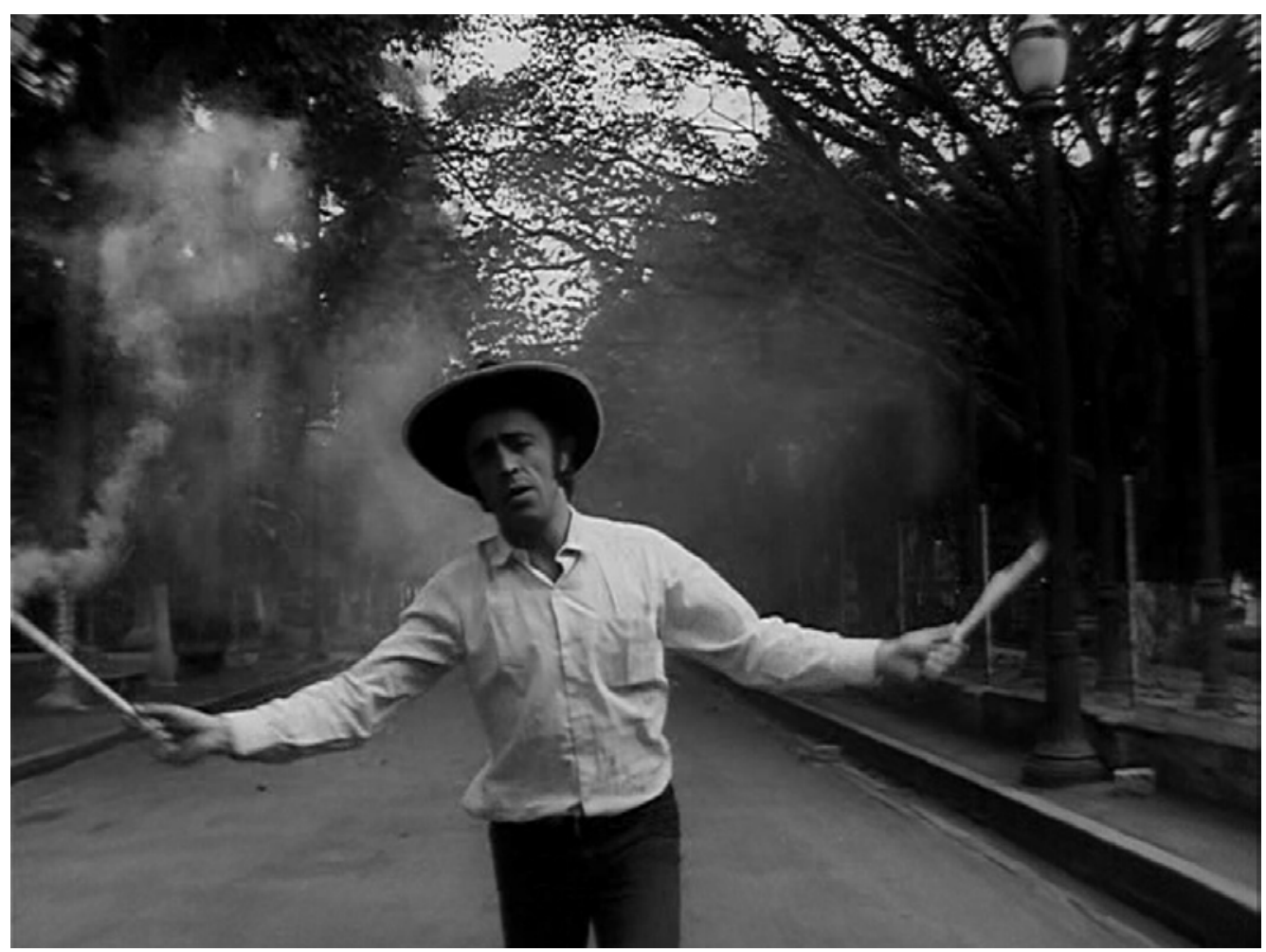

Fotograma do filme "O Bandido da Luz Vermelha"

Figura 104 - O Bandido vê seu retrato falado no jornal.

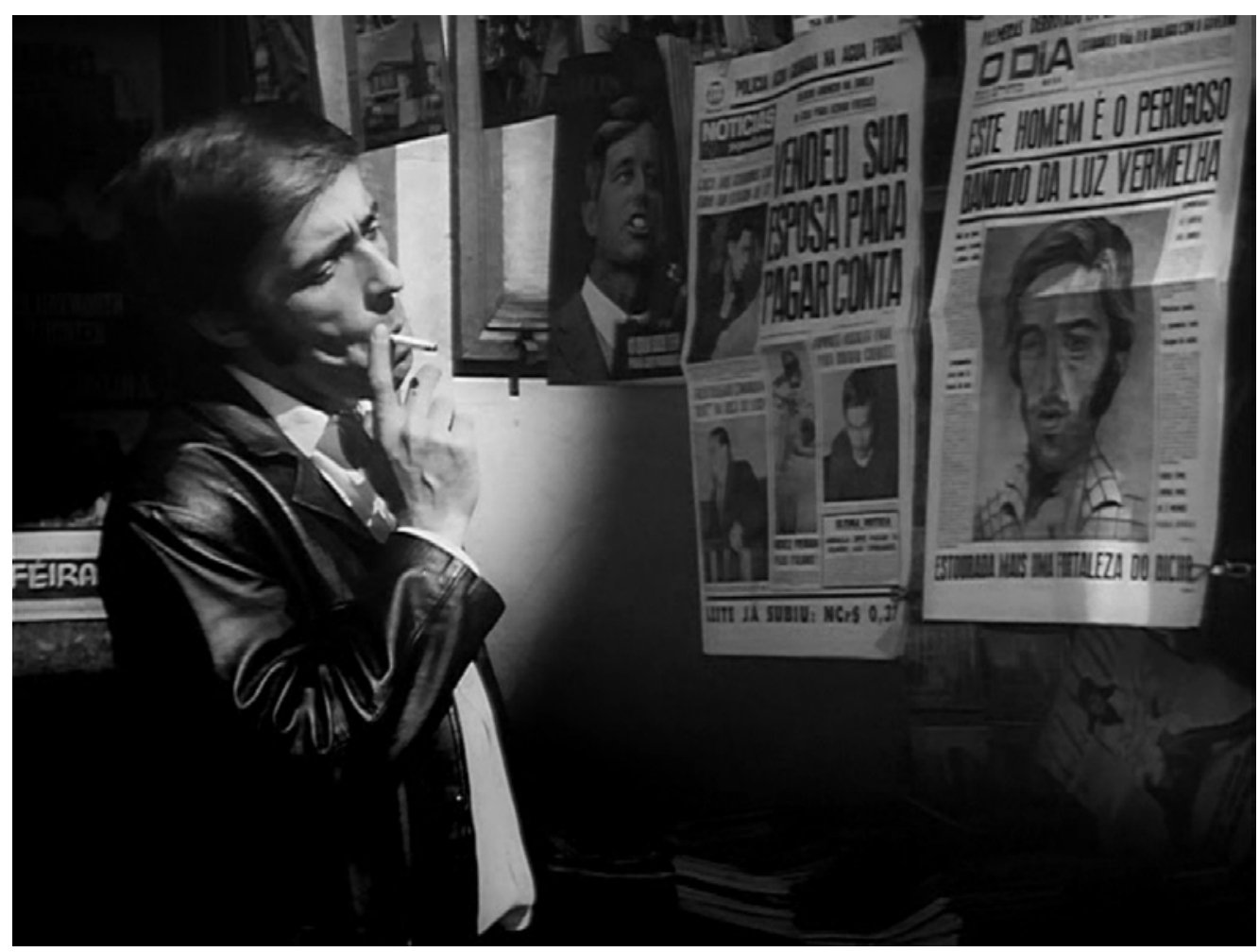

Fotograma do filme "O Bandido da Luz Vermelha" 
A última cena do Bandido com a mala é quando ele volta à favela do Tatuapé. Para Bernadet (1990), é o momento onde acontece o encontro do Bandido com sua identidade. Ele está de volta à favela onde inicia o filme, senta-se à beira de um rio com sua maleta aberta (as malas acompanham o Bandido durante todo o filme, malas cheias de quinquilharias com a palavra "EU" escrita no tampo interno, como pode-se observar na figura 105). Ele tira objetos disparatados de dentro da mala, joga um a um no rio e depois arremessa a própria mala. Ele não pode mais viver sem identidade e sem o fetiche (objetos da mala, o "EU" factício), e se dirige ao suicídio.

Figura 105 - O Bandido arremessa seus pertences da mala na água.

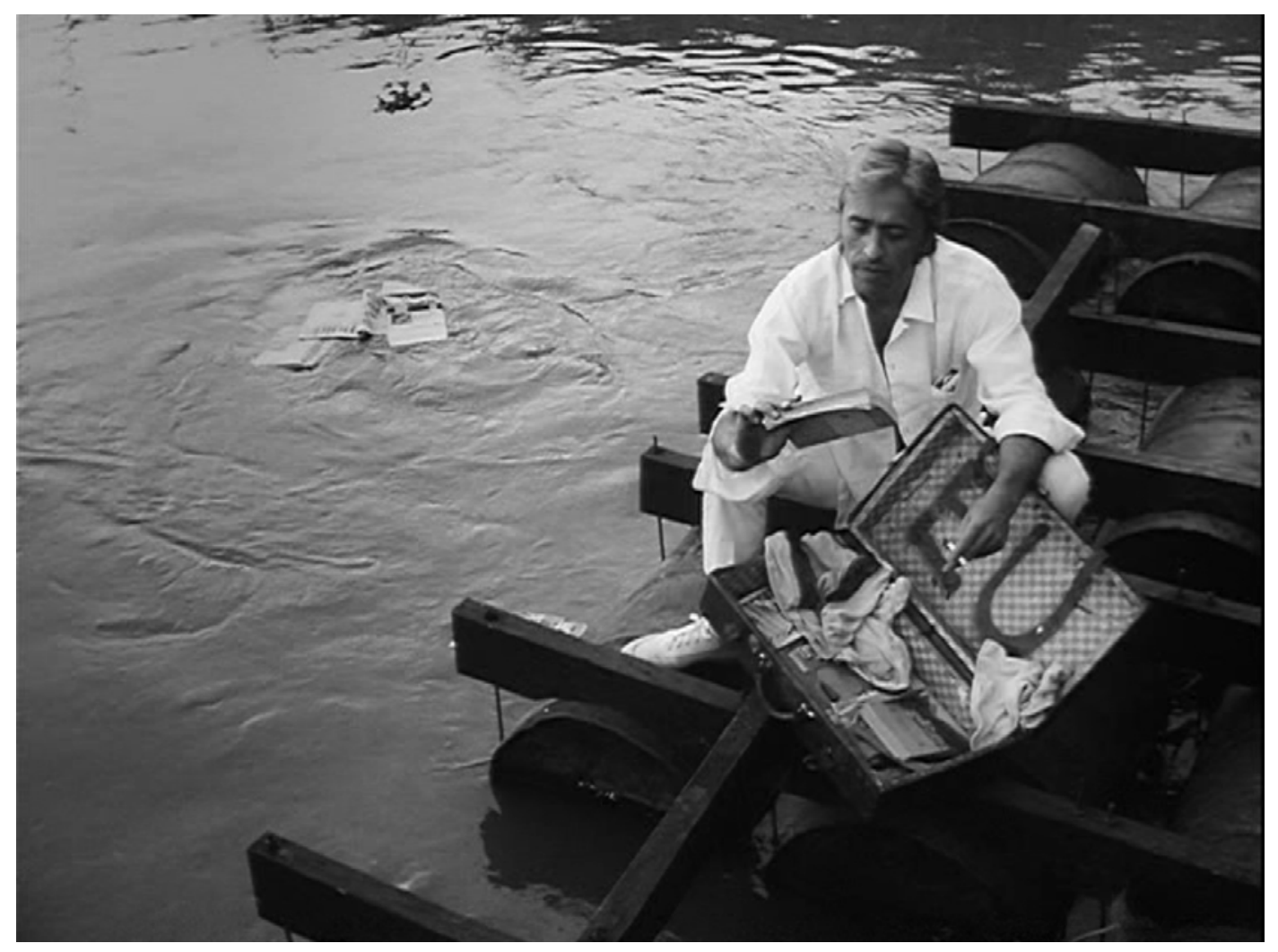

Fotograma do filme "O Bandido da Luz Vermelha"

O figurino expressa isso: nada de roupas espalhafatosas, ele está vestido todo em tom claro, fotografado como branco. Na religião cristã, o branco é a cor do prazer e pureza celestiais, é associada à Páscoa e à Ressurreição. Na vida secular, o branco sempre representou a pureza e a inocência (LURIE, 1997).

O personagem central usa uma roupa homogênea e harmoniosa. Neste momento, o protagonista está pronto para o suicídio que praticará logo em seguida, 
como se a morte ganhasse interioridade e identidade. O suicídio é um desejo do Bandido presente durante todo o filme, onde ele mesmo refere-se a tentativas mal sucedidas. Quando se suicida, diz: "Fracassei, mas vem outro".

O tecido da camisa é leve, e acrescenta um movimento esvoaçante quando o Bandido corre com ela aberta (figura 106). A leveza da camisa é contraditória com a situação de morte que sucede a cena, apesar do desejo de morrer do protagonista durante sua trajetória. A questão da morte não é colocada de forma catártica, metaforicamente é uma saída possível diante do absurdo. A calça, sem volume, deixa o personagem desprotegido e ao mesmo tempo demonstra seu lado erótico. $O$ comprimento curto da calça revela as meias envelhecidas, frouxas nos tornozelos do ator, que calça tênis claro. Um calçado mais leve, diferente das botas que fizeram parte do figurino do protagonista durante quase toda a narrativa.

Figura 106 - O Bandido corre às gargalhadas.

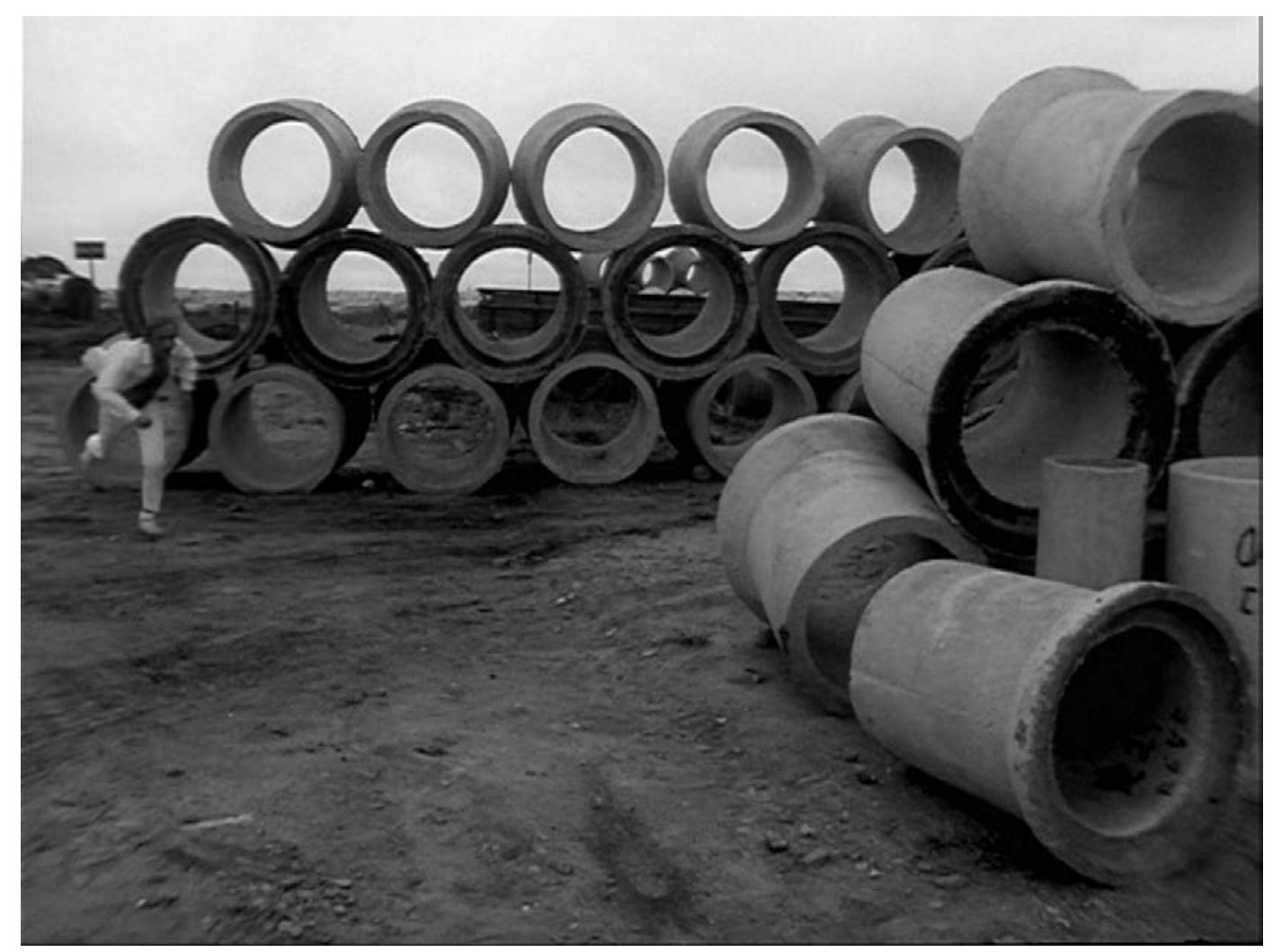

Fotograma do filme "O Bandido da Luz Vermelha"

O protagonista encaminha-se para o suicídio. Ele finge ter sido atingido no ombro por uma bala e cambaleia às gargalhadas, zombando da polícia que não conseguiu o prender (figura 107). 
Figura 107 - O Bandido finge ter sido atingido nos ombros.

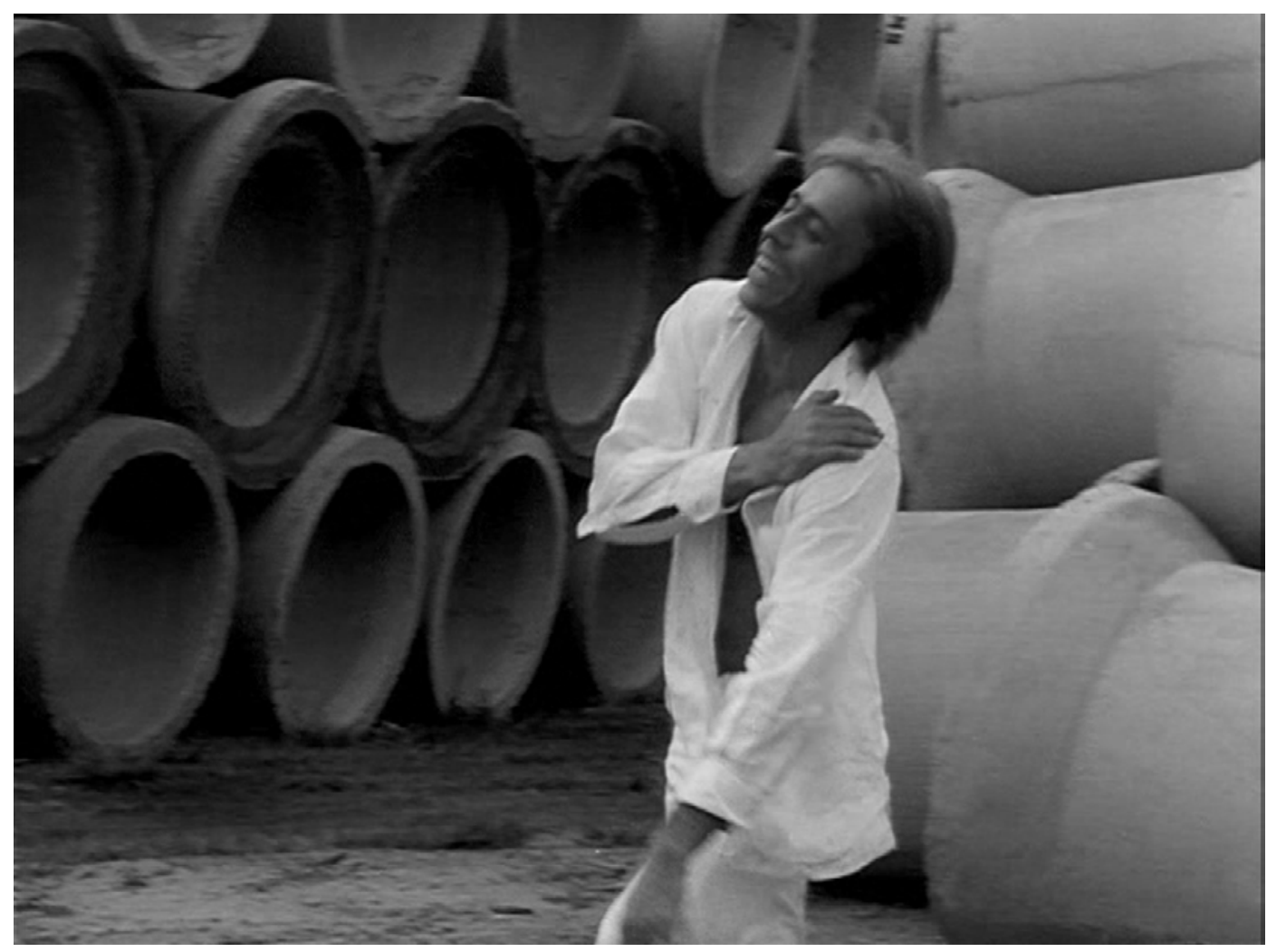

Fotograma do filme "O Bandido da Luz Vermelha"

Posteriormente, o personagem central envolve sua cabeça e seu tronco, agora sem camisa, com diversos fios elétricos, para em seguida pisar numa chave elétrica, morrendo eletrocutado. Neste momento, as meias do Bandido são reveladas frouxas e envelhecidas. O cadarço do tênis está frouxo, o que daria instabilidade ao andar do personagem, visível na figura 108. A ação final do herói é apresentada com muitos detalhes: primeiro plano do rosto, em seguida dos pés e por último da chave do circuito que se fecha. Antes de cair ao chão, o Bandido abre os braços como um gesto de libertação, o Cristo Redentor diante do caos, observado na figura 109. Nota-se a camisa alva do protagonista jogada atrás dele, sobre os escombros de concreto.

Todos os elementos do figurino desta sequência combinam entre si, calça, camisa, meias e calçado. O figurino é limpo, leve, harmonioso, sem contraste; o que se opõe à locação da cena, um lugar sujo, conflitante, cheio de entulhos. As variantes nomeadas por Roland Barthes (forma, movimento, peso, volume, equilíbrio e associação) estão presentes no look escolhido para esta cena, momento em que o Bandido se liberta. 
Figura 108 - O Bandido pisa na chave de força para se suicidar.

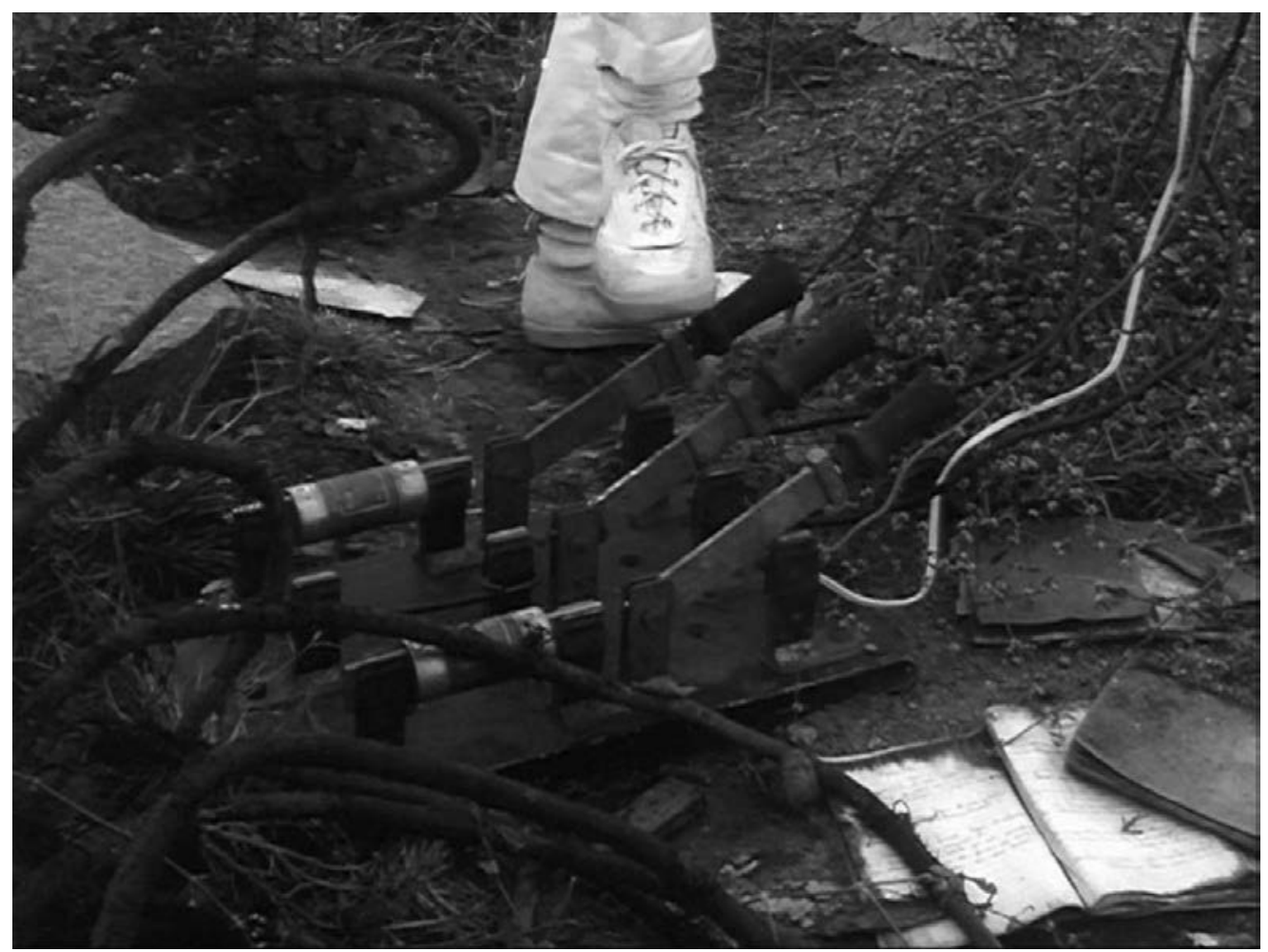

Fotograma do filme "O Bandido da Luz Vermelha"

Figura 109 - O Bandido abre os braços antes de cair ao chão.

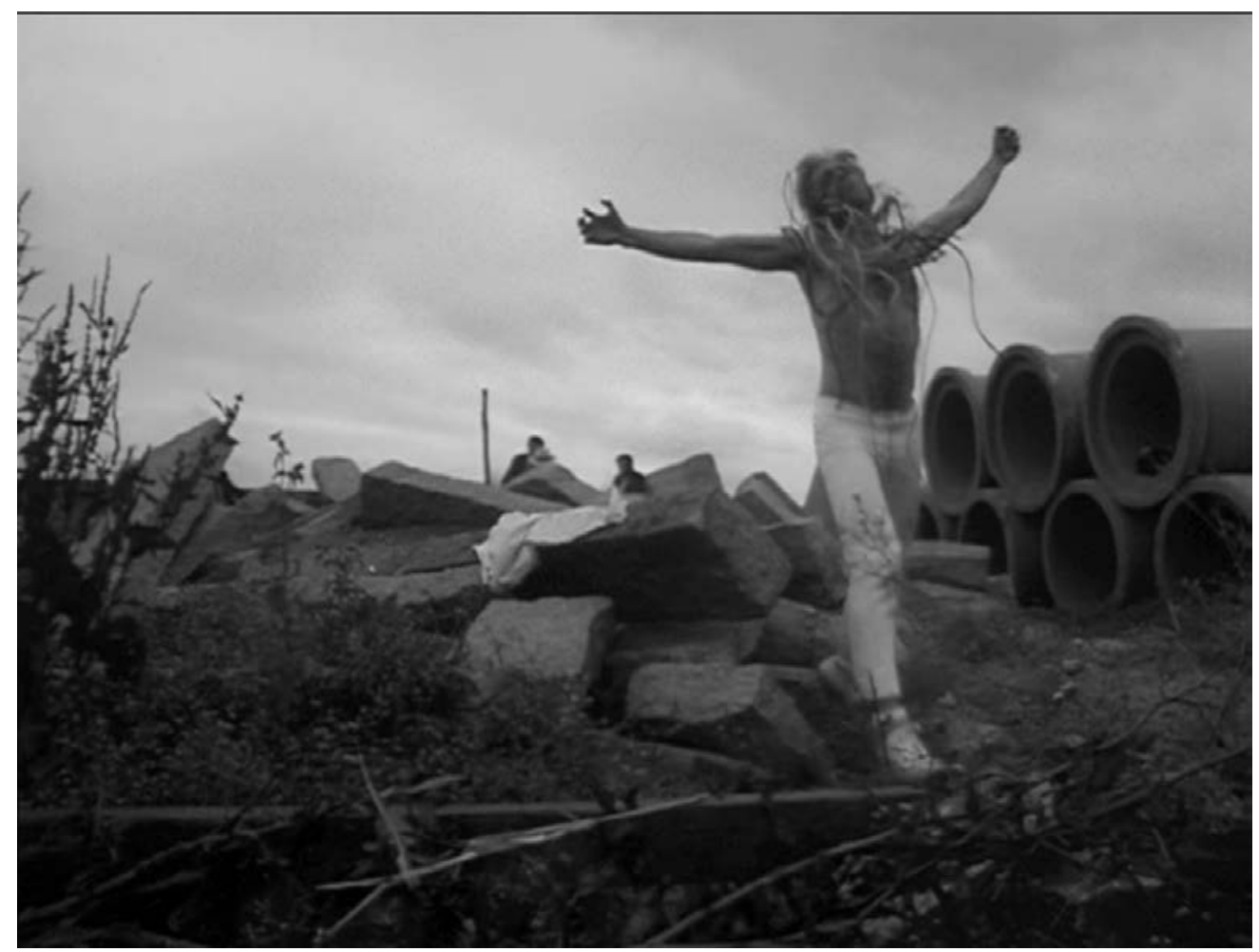

Fotograma do filme "O Bandido da Luz Vermelha" 
Em seguida a morte do Bandido a polícia chega, mas não acredita que aquele cadáver seja do Bandido da Luz Vermelha (figura 110). O delegado Cabeção, responsável pelo caso, desastrosamente pisa na mesma chave elétrica e também morre eletrocutado, pronunciando a última palavra do filme: "Mamãeeee". Ambos estão caídos paralelamente no chão com a mesma pose, como se houvesse uma simbiose entre os dois personagens, até então antagônicos. Um é o marginal e o outro é o funcionário da lei. O figurino do delegado opõe-se ao do Bandido, ele está vestido com terno escuro pesado, enquanto o Bandido tem seu dorso nu (figura 111).

Figura 110 - Delegado Cabeção observa o cadáver, mas não crê ser o Bandido da Luz Vermelha.

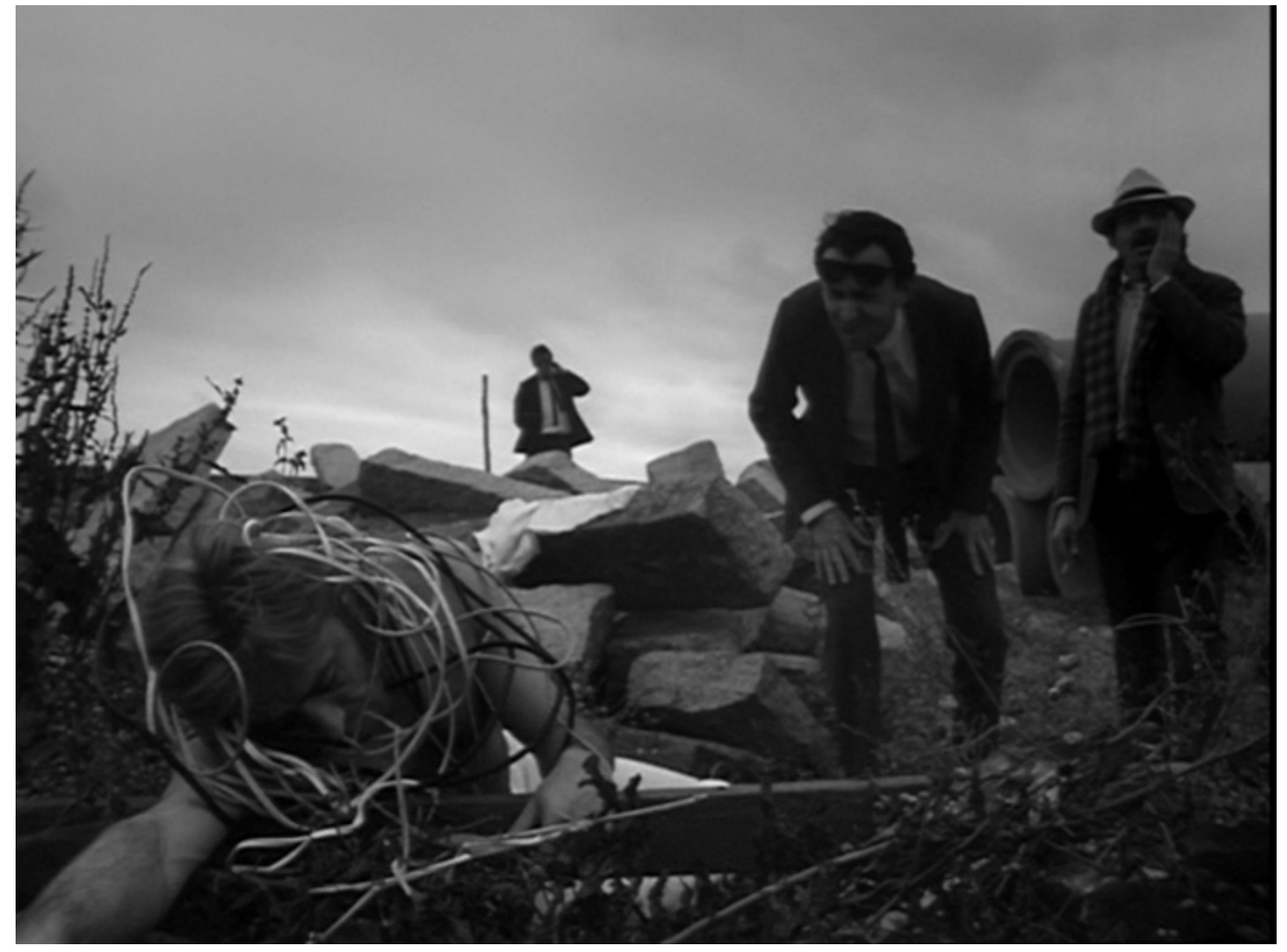

Fotograma do filme "O Bandido da Luz Vermelha"

Neste momento, pontua a tragédia uma melodia musical que alterna o batuque afro-brasileiro e a guitarra de Jimi Hendrix, uma colagem rock-candomblé no estilo da Tropicália (Xavier, 1993). É uma espécie de carnaval no lixo, misturado com discos voadores. 
Figura 111 - O Bandido e o Delegado Cabeção mortos, com a mesma posição

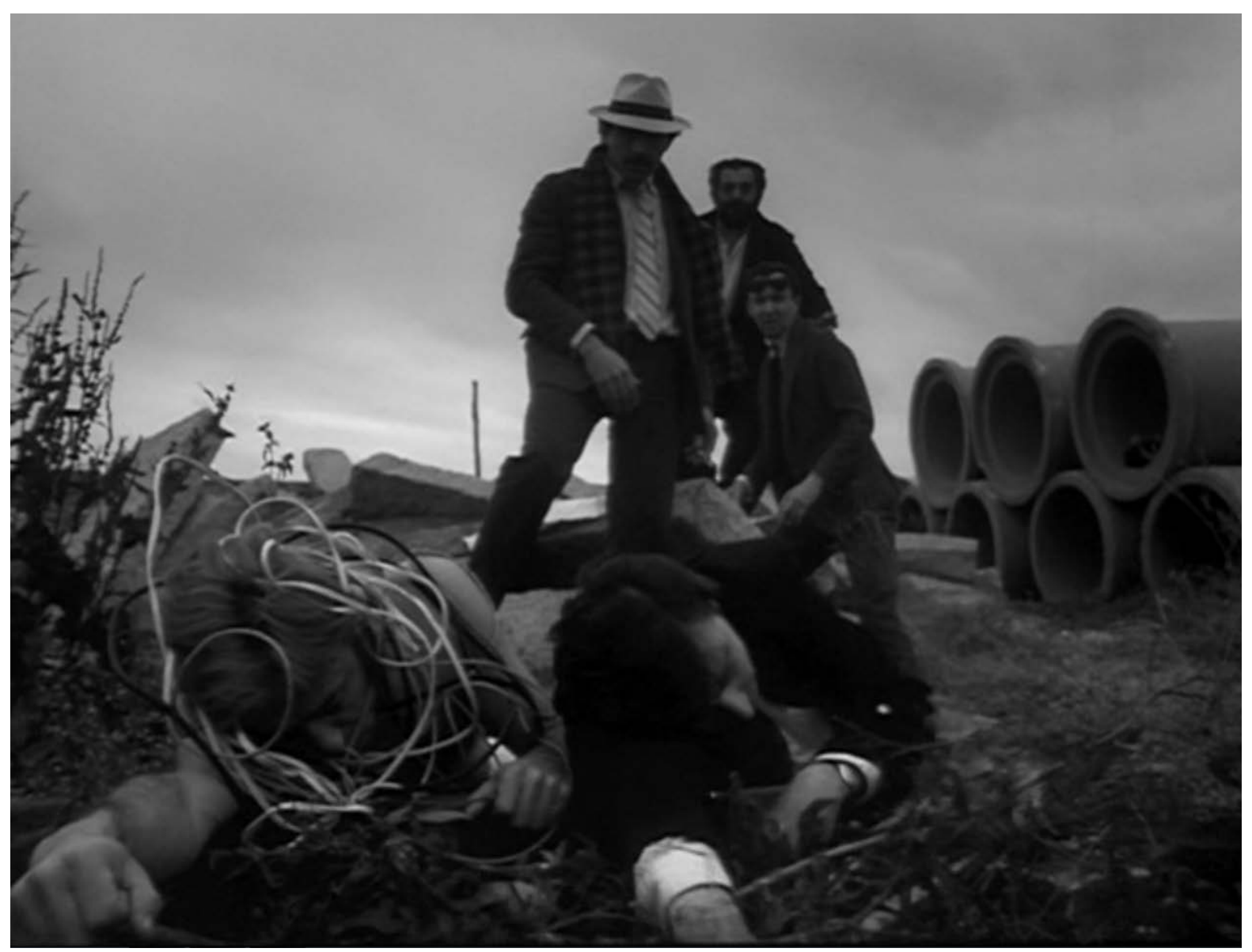

Fotograma do filme "O Bandido da Luz Vermelha"

Para Ismail Xavier (1993), a morte do bandido urbano é o ponto final de um processo autodestrutivo associado ao fracasso e à impotência. Seu suicídio tem um tom teatral, é espalhafatoso, num cenário urbano com lixo e poluição.

Como citado anteriormente, a cena do suicídio do Bandido é inspirada em outro suicídio, o do personagem Ferdinand, interpretado por Jean-Paul Belmondo em "O demônio das onze horas" (Pierrot Le fou,1965), de Jean-Luc Godard, onde o protagonista envolve a cabeça num rosário de bananas de dinamite e explode.

Segundo Sganzerla (2001), a tônica dos personagens modernos é a procura da liberdade, a busca de uma saída e, para alguns realizadores, muitas vezes a saída é a destruição do personagem, a morte, visualizada por um esquema plástico: o herói corre por um caminho fechado, estreito e aprisionador até desembocar em espaço aberto, a saída, onde encontra a morte. É assim que o personagem Michel de "Acossado" (Jean-Luc Godard) alcança a salvação. 
O figurino do protagonista demonstra uma constante instabilidade, mutabilidade que acentua a busca, ou a falta, de identidade dele. Figurinos que podem ser considerados de gosto duvidoso, ou qualificados de "ostensivo cafajestismo", como cita Jean-Claude Bernadet (1990, p.160), calça estampada, camisa preta e branca, cinto largo de três cores, chapéu de vaqueiro preto com debrum branco. Apesar desta unidade no gosto, o figurino é um instrumento para expressar uma indefinição, os elementos utilizados reforçam a realidade a ser compreendida.

É evidente que existe um destaque ao figurino neste filme, não só pela quantidade e mobilidade, mas pela relação que o Bandido mantém com ele, dando ação ao personagem. Em diversas cenas o protagonista está se vestindo, se despindo ou experimentando roupas e acessórios. Assim, o figurino nunca se estabelece. A procura pelo figurino ideal pode representar a busca da identidade do personagem. A instabilidade externa é um reflexo da instabilidade interna. O culto da aparência, do narcisismo torna-se um espetáculo ao público.

"O Bandido da Luz Vermelha" é um grande exemplo da vanguarda brasileira naquele período. Ele dialoga com a música tropicalista e com as artes plásticas e as criações geniais difundidas pela Pop Art. É um filme que pode ser interpretado como um caleidoscópio da atmosfera criativa presente durante o ciclo Marginal, considerado um dos mais férteis da cultura brasileira (CANUTO, 2006). 


\section{As entrevistas}

As entrevistas trouxeram informações relevantes que foram inseridas ao longo desta dissertação, principalmente aquelas relacionadas ao figurino. Porém diversas informações complementares também foram muito importantes. São questões paralelas ao figurino, mas que de certa forma contribuíram para uma melhor compreensão das escolhas estéticas do autor Rogério Sganzerla no filme "O Bandido da Luz Vermelha". Essas informações complementares são apresentadas a seguir.

O filme foi feito há mais de quarenta e cinco anos, poucas pessoas estavam disponíveis para relatar os fatos. Foram realizadas entrevistas com três profissionais que participaram da produção, cada um numa área diferente e, assim, foi possível iniciar um entendimento de como foi concebido o figurino do filme. Através da análise dos depoimentos, é possível levantar diversos aspectos em todas as áreas envolvidas.

Foram entrevistados para esta pesquisa:

- Carlos Ebert: Diretor de Fotografia e Câmera do filme. Como citado anteriormente, no processo criativo atual, o Diretor de Fotografia faz parte do tripé da concepção do filme juntamente com o Diretor do Filme e o Diretor de Arte (EBERT, 2013).

- Julio Calasso Junior: Diretor de Produção do filme. Peça fundamental para as decisões artísticas da obra, pois é ele quem administra o orçamento, viabiliza as locações e dá ao Diretor do filme as condições gerais para filmar (CALASSO, 2015).

- Helena Ignez: atriz do filme. Participa diretamente da criação da personagem em conjunto com o Diretor. Trouxe detalhes do figurino e da maneira como Rogério Sganzerla lidava com o elenco (IGNEZ, 2015).

Algumas situações são expostas sempre que possível exemplificando com imagens do filme. Existem poucas contradições entre os entrevistados e, quando ocorrem, são apresentadas as duas versões.

Alguns aspectos são unânimes para os três profissionais. Todos os entrevistados citam a liberdade criativa dada à equipe por Rogério Sganzerla. Ele 
aceitava ideias e as incorporava. Ao mesmo tempo, ele sabia muito bem o que queria, sem jamais perder o foco. Todos consideram o autor um "gênio".

A equipe de filmagem era bastante pequena, se comparada à uma equipe de cinema de hoje em dia. Isso fazia com que a direção tivesse maior agilidade, uma grande mobilidade que possibilitava a realização do tipo de filme realizado, um cinema de rua.

Todos discordam da nomenclatura "Cinema Marginal", inclusive citam o descontentamento de Rogério Sganzerla com este título. Ignez comenta que Sganzerla dizia "marginal é o país". Era um cinema sem incentivo do governo, mas o filme foi uma das maiores bilheterias do cinema, portanto não poderia ser considerado à margem da indústria.

Tanto Ebert como Calasso destacam o roteiro do filme como exemplar. Ebert diz que Sganzerla escreveu e reescreveu o roteiro diversas vezes até obter uma elaboração detalhada. O autor tinha um controle muito grande de tudo, da interpretação, da câmera, das locações. Calasso destaca a disciplina de Sganzerla ao seguir o roteiro.

As cenas eram ensaiadas diversas vezes, juntamente com as marcações, e só depois a sequência era rodada, pois os negativos eram muito caros e raros naquela época.

Segundo Ebert, o ator Paulo Villaça interpretava tão bem o personagem que, muitas vezes, ao terminar as filmagens continuava atuando. A equipe brincava avisando o protagonista que ele já não estava mais em cena. O ator trouxe muitas ideias para o filme e cooperava bastante com as solicitações da direção. Inclusive houve uma cena em que Sganzerla pediu para Villaça beber água num bidê de um hotel de prostituição e, depois de alguma relutância, acabou aceitando fazer a cena, conforme mostra a figura 112.

O protagonista colaborou com muitos figurinos e, segundo Ebert, trazia diversos itens. Muitos figurinos também foram comprados na Boca do Lixo mesmo. Calasso confirma estas informações e completa que, naquela época, a maioria das lojas de roupas de São Paulo estava localizada na região central. 
Figura 112 - O ator Paulo Villaça bebe água no bidê num hotel da Boca do Lixo.

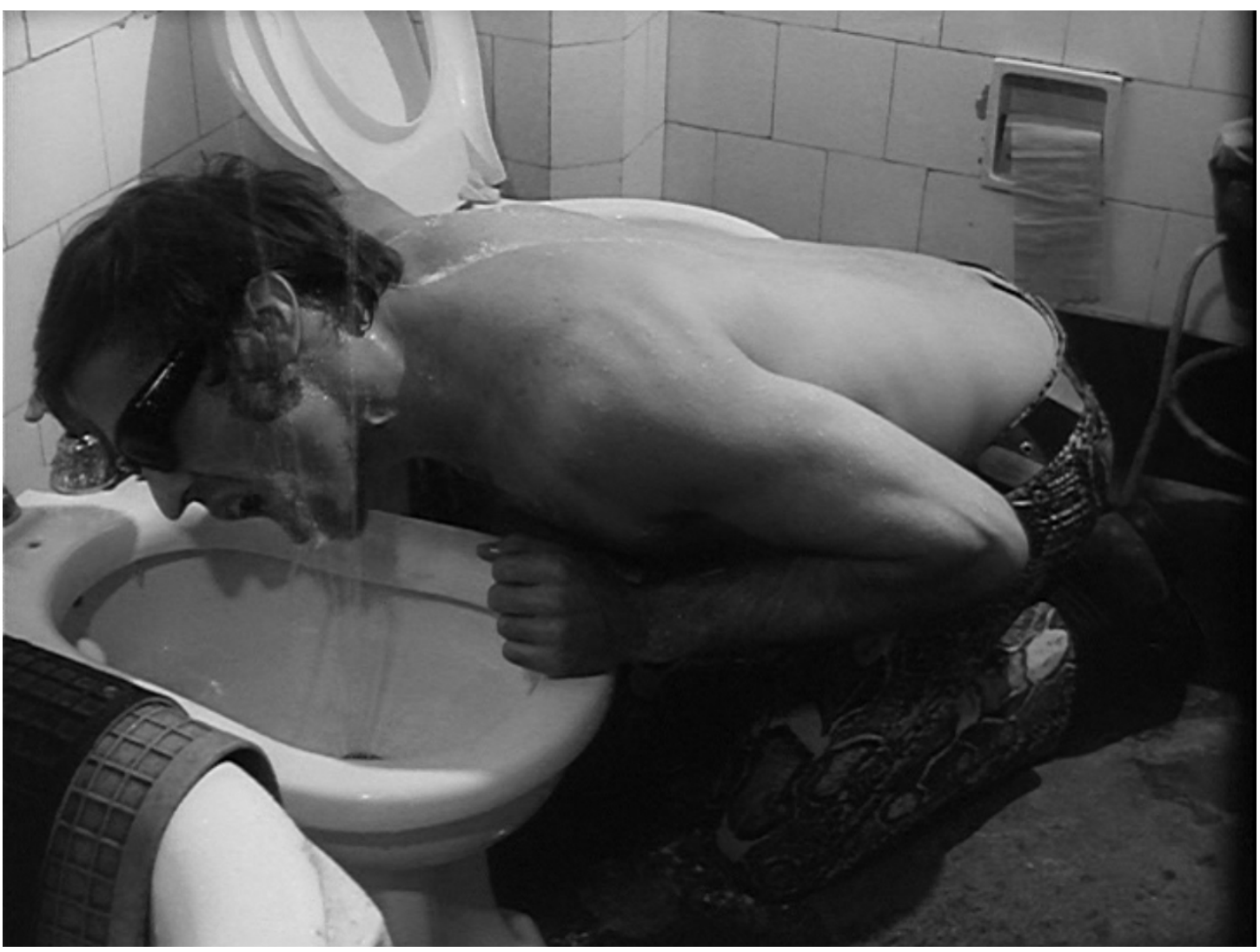

Fotograma do filme "O Bandido da Luz Vermelha"

Quanto à paixão por botas, Julio Calasso Junior diz que o ator Paulo Villaça andava de botas na vida real e que provavelmente as botas usadas pelo personagem eram do próprio ator.

Helena Ignez comenta que Villaça era um homem muito elegante e que ele e Sganzerla se divertiam muito com os figurinos do "Bandido", que eram totalmente pop e muito à frente de seu tempo. Ela chega a dizer que o personagem era inspirado em Roberto Carlos.

Ebert conta que os amigos também contribuíram muito com o filme. Emprestavam figurino, locações, faziam participações. Inclusive uma das locações que serve para diversas cenas, era um apartamento de uma amiga em Higienópolis, Renata de Souza Dantas. A cena do banheiro em que o Bandido dá uns tiros numa mulher no chuveiro; quando ele escreve "Merci" nas costas de uma garota (vide figura 113); a sequência da cozinha em que o protagonista coloca diversos ingredientes no liquidificador e bate; e outras tantas foram filmadas neste apartamento, que a equipe passou a chamar de "nosso estúdio". 
Figura 113 - O Bandido escreve "Merci" nas costas de uma de suas vítimas.

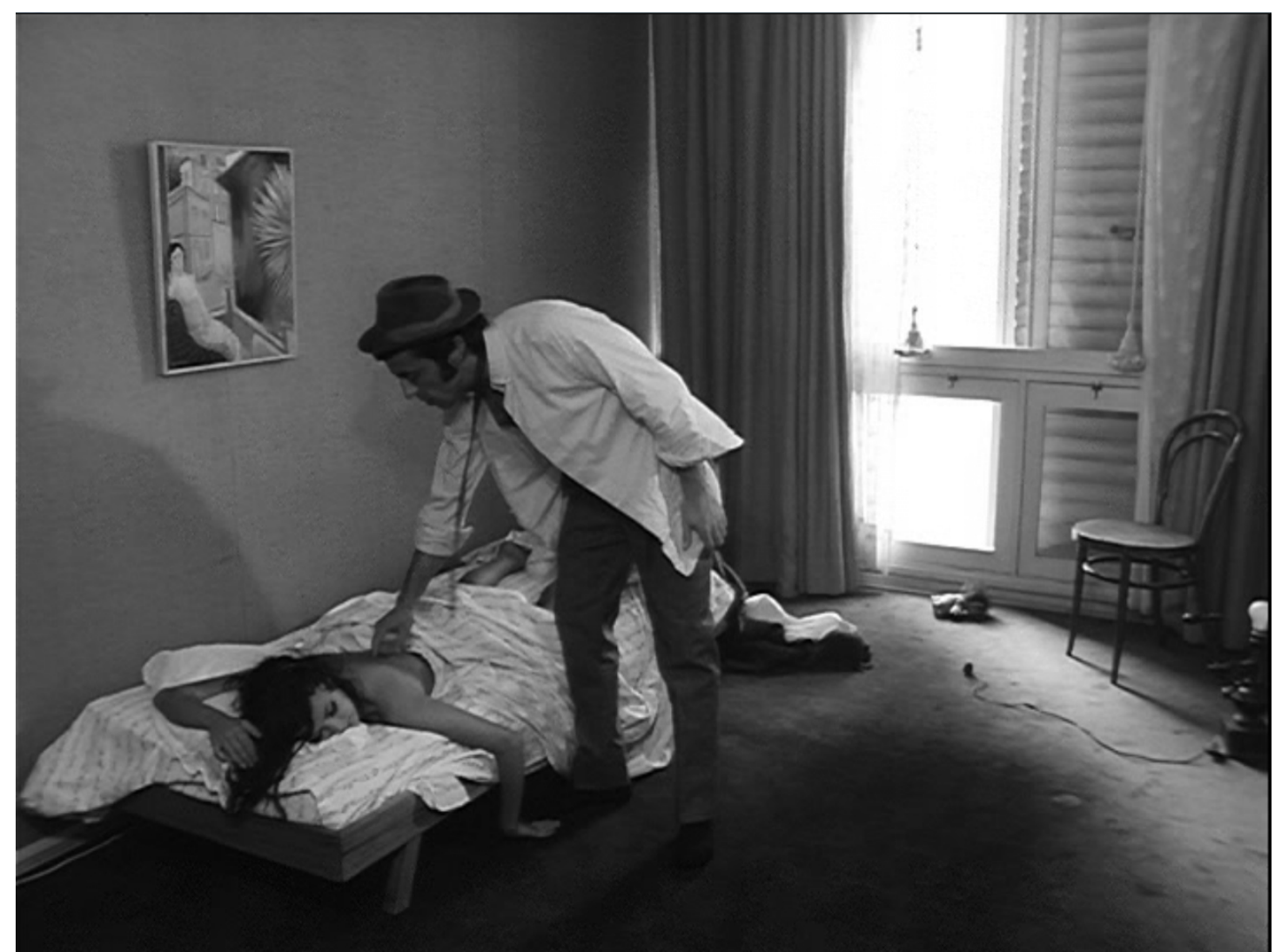

Fotograma do filme "O Bandido da Luz Vermelha"

O produtor Julio Calasso Junior também tem uma participação na fita como ator. Numa das cenas dentro da sala de cinema, um ator faria o papel de um homossexual que fica importunando os espectadores. Porém, a pessoa desistiu de fazer o personagem na última hora. Como não existia tempo e nem verba para adiar a filmagem, Calasso resolveu fazer a cena. Não houve preparação de elenco e nem de figurino, ele foi vestido exatamente como veio para trabalhar no set como mostra a figura 114.

O fotografo Carlos Ebert usou para fotografar a mesma lente que Orson Welles usou em "Cidadão Kane", a grande angular 20 mm. Ele comenta que este tipo de lente com a câmera na mão, ou em movimento, pode se constituir em um problema porque tudo está em quadro, mas para eles não foi. A câmera ficava solta, na cadeira de roda, ou na mão. Ele chegou a usar um pano amarrado no equipamento para ela ficar mais estável. A equipe tinha que estar posicionada atrás da câmera porque senão "entrava em quadro". Ebert tinha que estar muito atento para seguir alguma movimentação improvisada que o ator Paulo Villaça fizesse. Além disto, este tipo de lente causa uma distorção quando a pessoa chega muito 
próxima. Rogério Sganzerla usava muito este recurso. Tem vários momentos em que a aparência de Paulo Villaça é distorcida, reforçando a dramaticidade de seu rosto, conscientemente, visível na figura 115.

Figura 114 - Julio Calasso Junior faz uma ponta no filme.

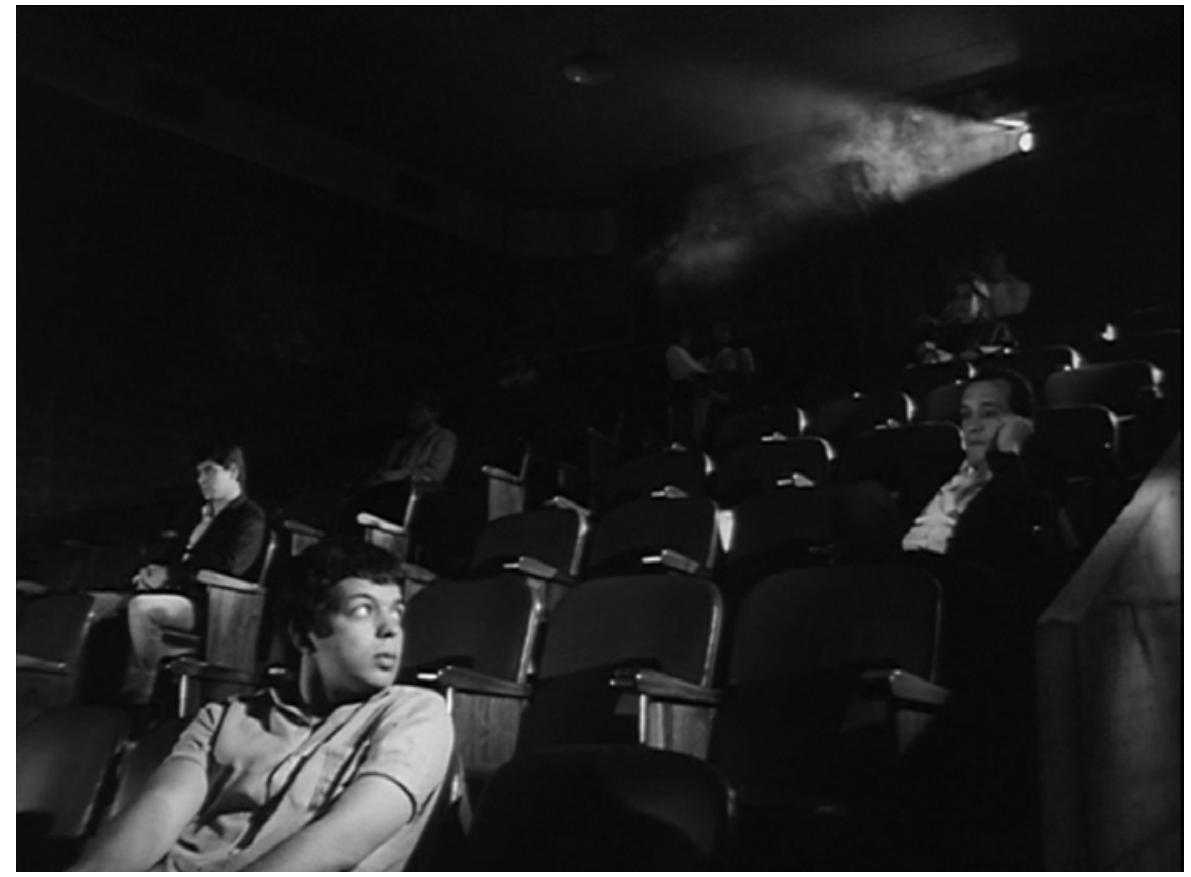

Fotograma do filme "O Bandido da Luz Vermelha"

Figura 115 - As feições rosto do Bandido são distorcidas quando o ator se aproxima da câmera.

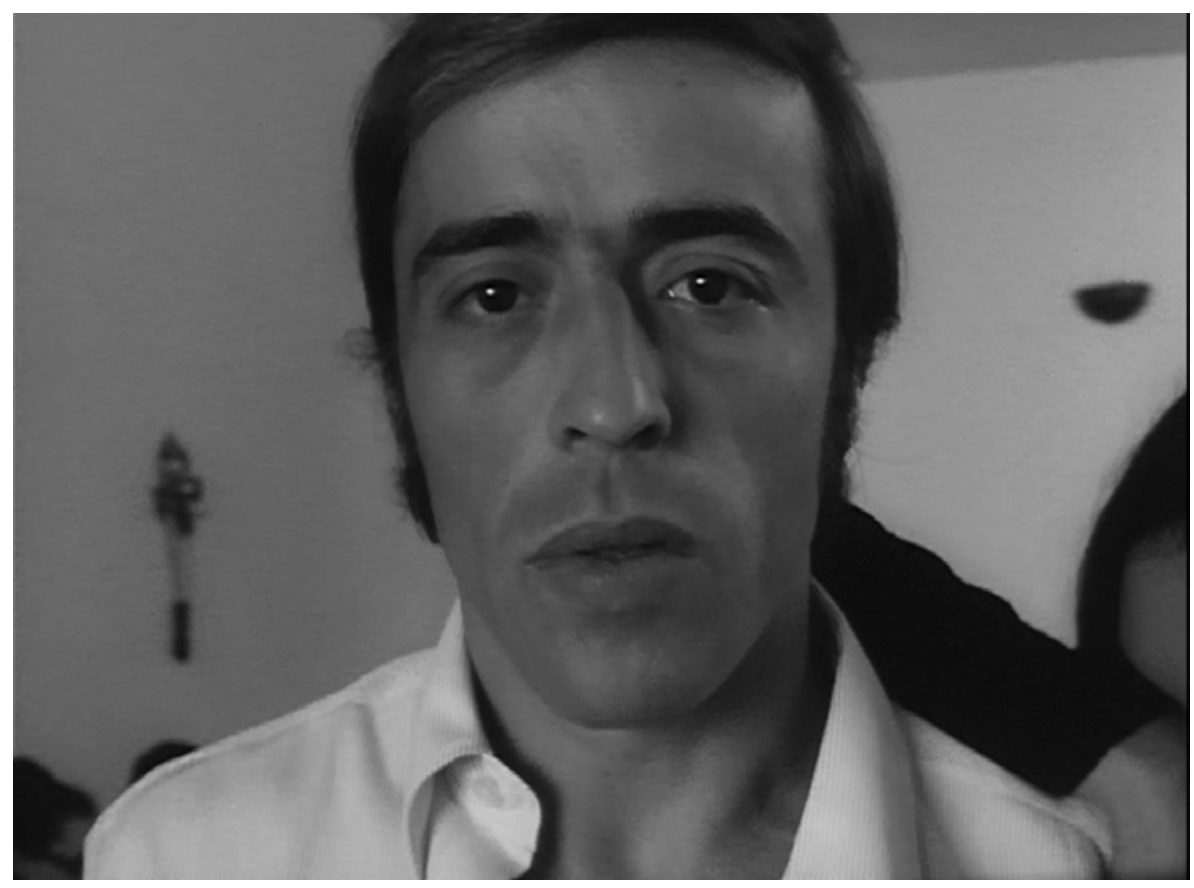

Fotograma do filme "O Bandido da Luz Vermelha" 
Helena Ignez entrou no filme quando as filmagens já haviam começado. Pediu autorização para Sganzerla para chegar depois, pois estava fora do Brasil participando de festivais com o filme "O Padre e a Moça", de Joaquim Pedro de Andrade. Rogério Sganzerla pediu que ela viesse vestida com minissaia e botas. A atriz comenta que trouxe o figurino do exterior, as botas eram Courrèges, a minissaia era Mary Quant, e a camiseta era emprestada de uma amiga, Maria do Rosário Nascimento da Silva, uma atriz da época. Porém, o produtor Julio Calasso Junior tem outra versão para esta história. Ele diz que foi buscar a atriz na rodoviária da Luz. No caminho entre a rodoviária e a locação, onde seria feita a filmagem, eles compraram a minissaia preta e a blusa branca que a personagem usa praticamente o filme todo.

O filme foi feito em 1968, em plena ditadura militar. Fazer um filme onde um Bandido sai dando tiros pela cidade num momento de repressão no país não era algo simples. Julio Calasso Junior conta que conseguia as viaturas de polícia com o Delegado Sérgio Fleury (militar que mais tarde foi considerado uma das pessoas mais cruéis da Ditadura brasileira). Inclusive relata uma situação onde existia um meliante dentro de uma viatura, e para a equipe não perder a filmagem, o Delegado Fleury pediu para que algemasse o sujeito no poste, enquanto a cena era feita. Já Carlos Ebert conta que quando estavam chegando da filmagem no escritório da produtora na Boca do Lixo, havia um cidadão algemado no poste e ele filmou a situação, que acabou entrando no filme. A cena está no filme como pode-se ver na figura 116

Helena Ignez diz que Rogério Sganzerla aproveitou muito as roupas de uma atriz da Boca do Lixo, que contracenou com ela na cena da morte. Além de atriz, ela era uma garota de programa e trouxe diversos itens, inclusive a cinta-liga (figura 117).

Julio Calasso Junior também confirma a colaboração de todos com o figurino, fala sobre a criação conjunta. Comenta que a capa e os óculos do "nazista" que acompanhava J. B. Da Silva, o Lucho Gatica, surgiram para complementar o personagem (figura 118).

A maquiagem da personagem Janete Jane foi uma ideia em conjunto com Rogério Sganzerla, segundo Helena Ignez. O diretor gostaria que os olhos fossem carregados, escuros, o que era de certa forma simples para a atriz executar. Então, 
assim, ficou definida a maquiagem, como poder ser vista na figura 119. Não existia maquiador no set.

Figura 116 - Cidadão algemado no poste na Boca do Lixo.

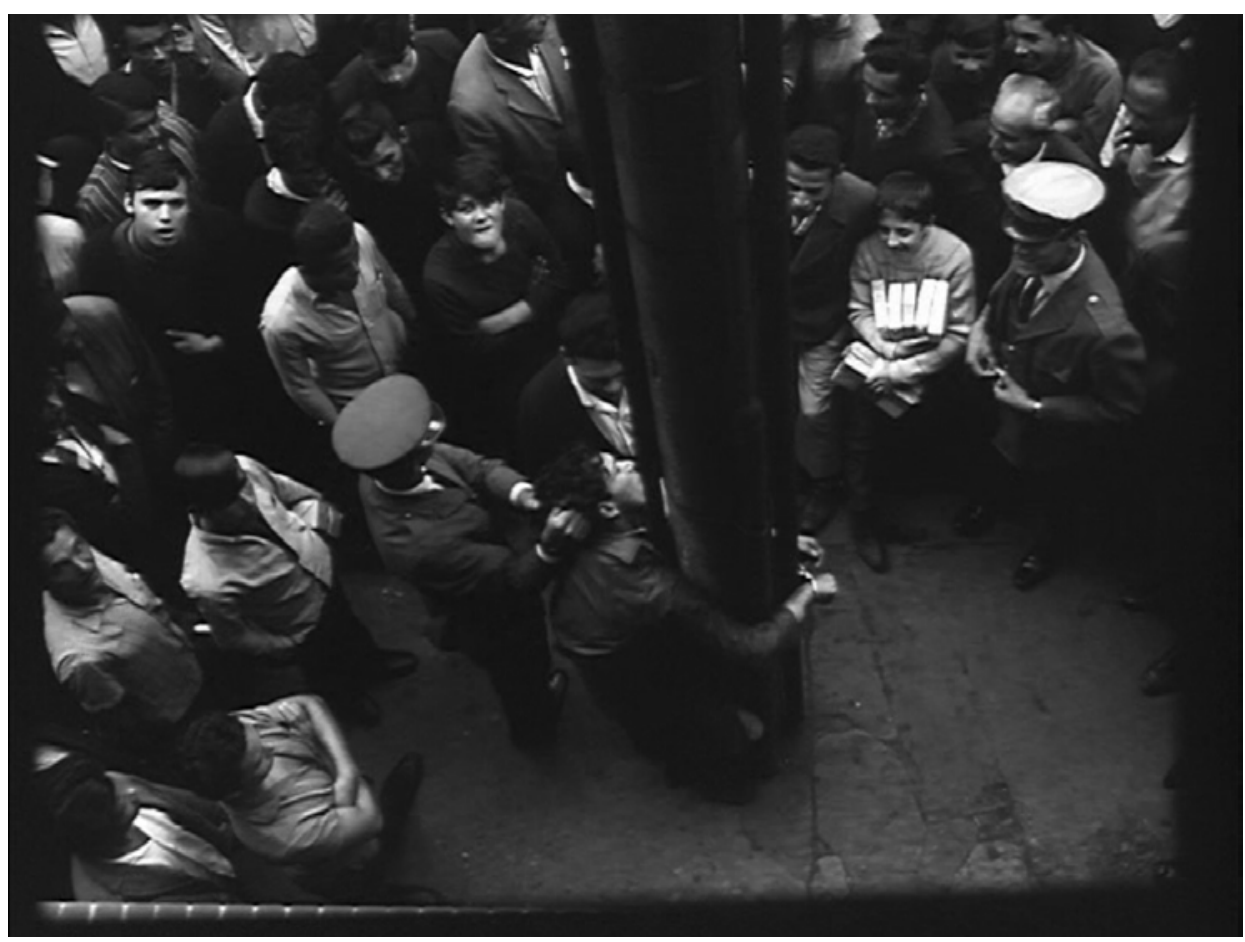

Fotograma do filme "O Bandido da Luz Vermelha"

Figura 117 - Prostituta com cliente usando cinta-liga.

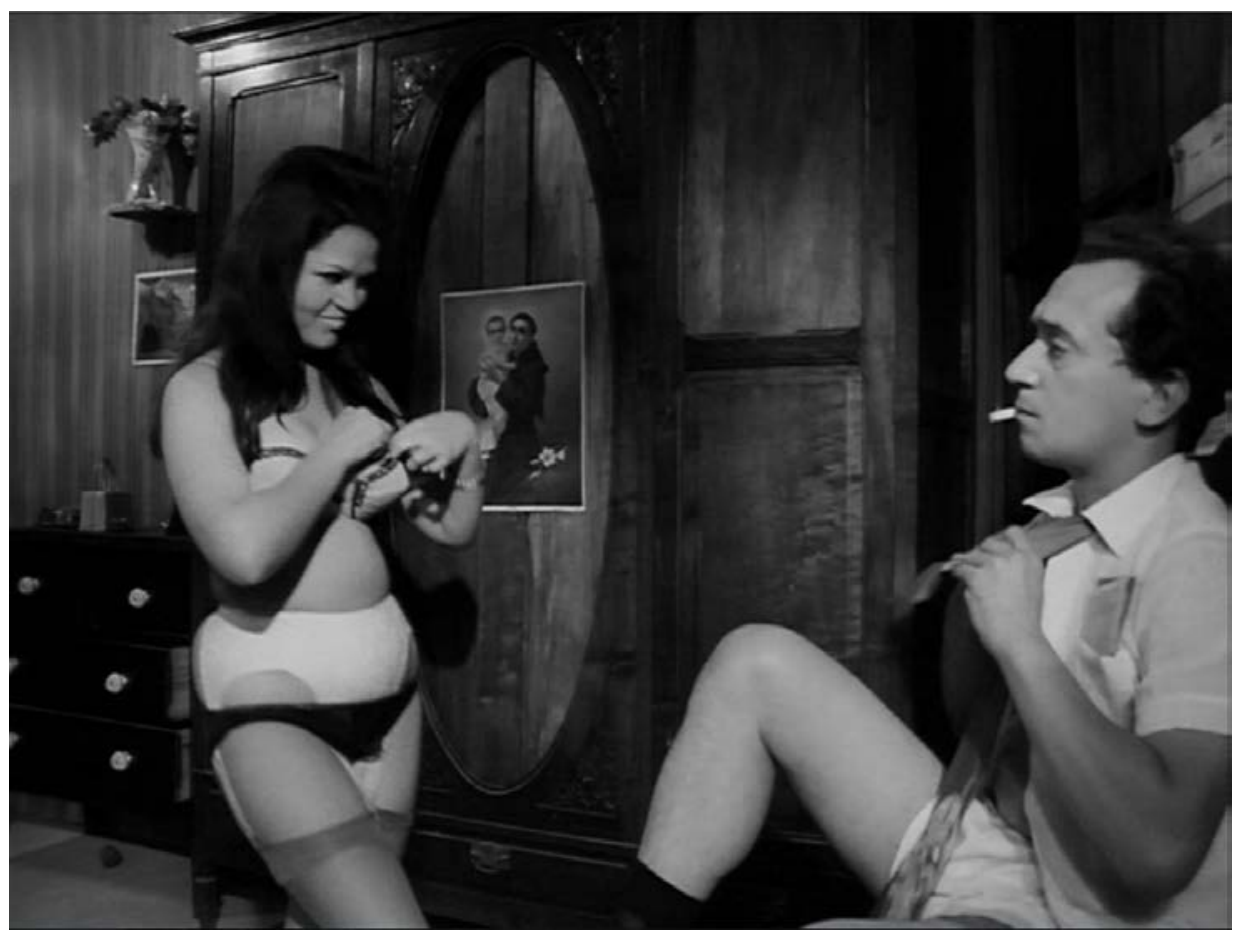

Fotograma do filme "O Bandido da Luz Vermelha" 
Figura 118 - Lucho Gatica usando capa e óculos.

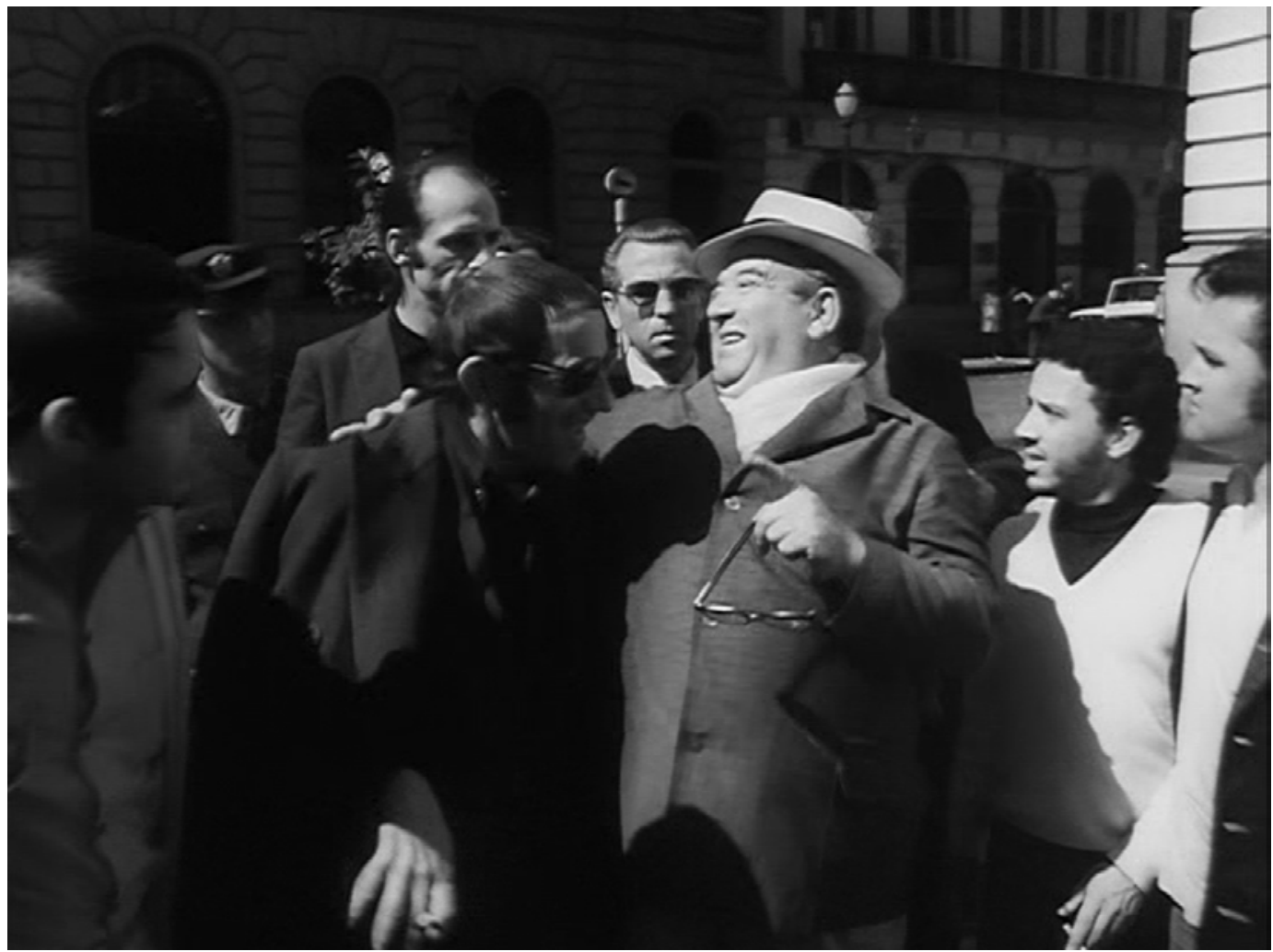

Fotograma do filme "O Bandido da Luz Vermelha"

Figura 119 - Maquiagem da personagem Janete Jane.

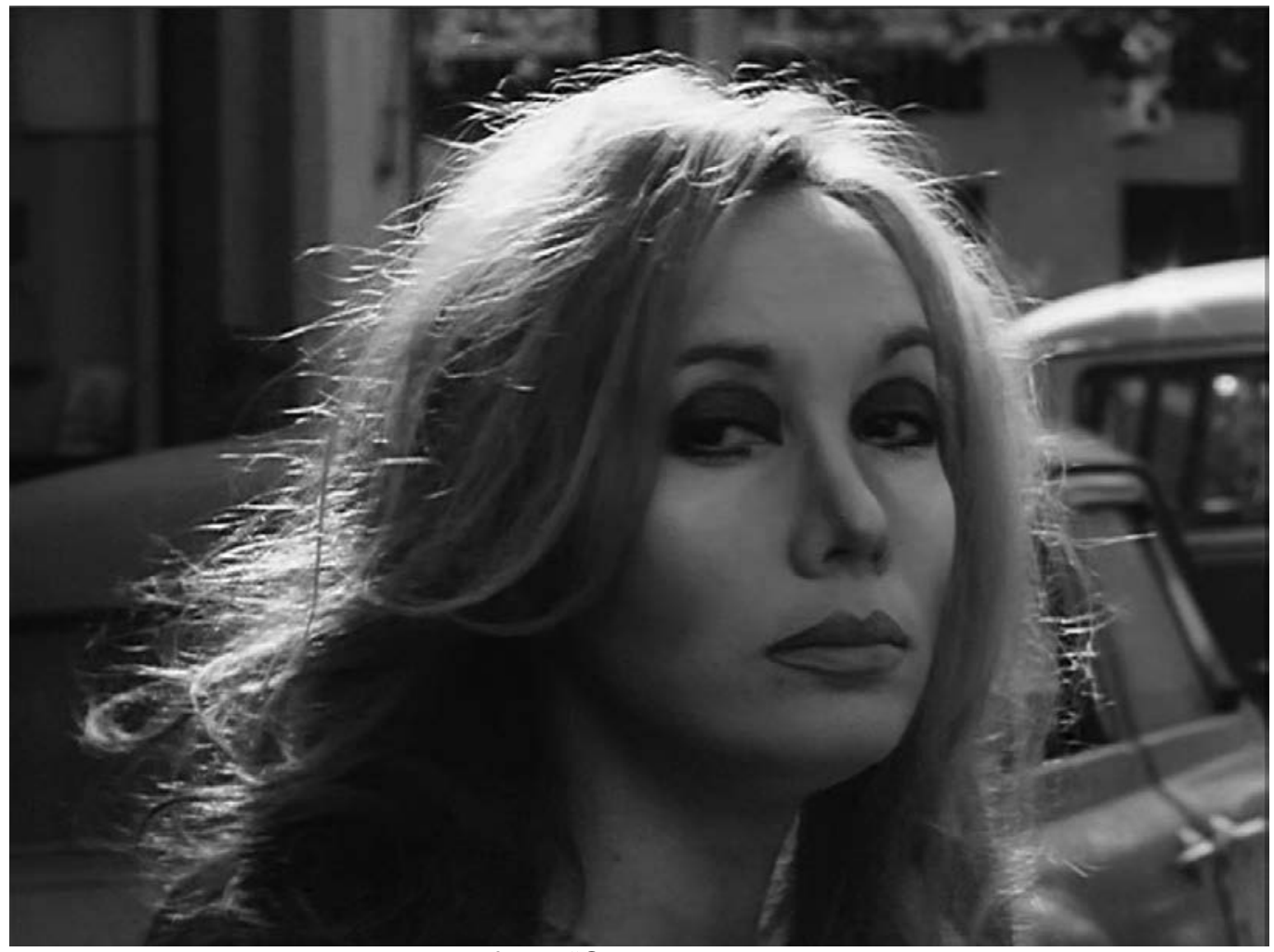

Fotograma do filme "O Bandido da Luz Vermelha" 
Julio Calasso Junior define o figurino do filme como "parte de alguma coisa que estava acontecendo na época e onde ele era um signo importante nessa mudança de atitude, de perspectiva, de visão, do que era o quadro cinematográfico". Os trajes seriam uma das expressões desta transformação que "O Bandido da Luz Vermelha" estava trazendo. Ele reconhece o figurino como elemento desta invenção. Para ele, conceitualmente é isso. (CALASSO, 2015). 


\section{Conclusão}

Ao analisar filmes, percebe-se a existência de uma relação das imagens do figurino com os textos dos filmes que colabora para a expressão total da narrativa. Os figurinos, muitas vezes, complementam as falas das personagens. Eles representam e materializam sua personalidade.

No caso do filme analisado, os figurinos do personagem central, o Bandido, apesar de terem uma variação grande, na maioria das vezes, mantêm a mesma silhueta. Figurinos sem volume, em tecidos leves (salvo um blazer de couro escuro), simétricos, e com movimento em algumas situações. Calças justas para enfatizar sua virilidade, camisas ou camisetas próximas do corpo, a fim de mostrar o corpo forte do personagem e salientar seu lado sensual, botas e meias escuras, combinadas com cintos largos. Em certos momentos, são acrescentados blazers ou chapéus. As listras aparecem em mais de um figurino do personagem. As associações (combinação das peças) são extravagantes. O ator utiliza-se, frequentemente, do figurino para suas ações. Inclusive em muitas situações do filme é dado destaque ao figurino com sequências dedicadas à troca ou escolha de roupas e acessórios, corroborando a relevância do figurino à narrativa.

A importância dada a estas trocas de roupa durante os assaltos do Bandido ou a escolha das composições dos trajes do protagonista ao longo da narrativa, assim como suas ações relacionadas às peças de roupas, fazem do figurino um personagem dentro da trama.

Os figurinos dos outros personagens do filme possuem certa estabilidade. Sua amante Janete Jane mantém praticamente o mesmo figurino durante toda a narrativa. Figurino com contraste de cor e peso. Look usado pelas mulheres modernas da década de 60. Ela é o retrato da femme fatale do cinema noir, cabelos longos loiros com volume, olhos com maquiagem escura, minissaia e camiseta justa dando destaque aos seios.

O político J.B. Da Silva usa um figurino tradicional de um político, às vezes exagerado por alguns acessórios como um foulard ou robe de seda adamascado. Detalhes que apontam seu lado excêntrico e menos conservador, na questão vestimenta. 
O Delegado Cabeção também é o retrato clássico de um policial no cinema. O uso dos óculos escuros ajuda no gestual do ator, presente em quase todas as cenas. Não existe grande variação no traje do policial.

Todos os personagens são muito bem caracterizados e existe uma unidade estética em todo o filme. Apesar de não haver um figurinista responsável pelos trajes, fica claro que as composições entre os personagens e cenários foram pensadas e bem trabalhadas.

O papel do figurinista ficava diluído entre elenco e a direção, com ajuda da produção, conforme os exemplos citados. Os atores traziam suas próprias roupas e eram responsáveis pela manutenção e continuidade dos trajes. Existia um acúmulo de função para diretor, tanto em relação ao figurino (que solicitava o figurino e aprovava os looks) quanto à direção de arte e assistência de direção.

Os parâmetros de Roland Barthes foram úteis para realizar a descrição dos figurinos, assim como avaliar a estrutura de cada um em relação à forma, movimento, peso, volume, equilíbrio e associação. A análise detalhada das vestimentas reforçou os motivos da seleção de tons e acessórios para o elenco, de acordo com o perfil do personagem.

As entrevistas auxiliaram no entendimento sobre as escolhas dos figurinos usados no "Bandido da Luz Vermelha", mas ainda se faz necessário obter mais informações sobre outras produções para aprofundar o processo criativo no Ciclo Marginal.

A criação em conjunto, que faz parte do meio cinematográfico até hoje, já era clara e presente na obra de Rogério Sganzerla. Os entrevistados desta pesquisa comentam mais de uma vez que muitas decisões eram tomadas em grupo e as ideias também eram coletivas.

A estética do filme "O Bandido da Luz Vermelha" é referência para diversos cineastas, diretores de arte e figurinistas da atualidade. Assim como o gênero policial, a violência urbana e a corrupção presentes nesta obra são temas recorrentes na atual cinematografia brasileira, permitindo reconhecer as rupturas existentes no Cinema Marginal de Rogério Sganzerla, desde 1968. 


\section{Referências}

BARTHES, Roland. Sistema da moda. São Paulo: Editora WMF Martins Fontes, 2009

BATISTTI, Francisleth Pereira. Moda e figurino: unilateralidade. Maringá: Primeiro Encontro de Paranaense de Moda, Design e Negócios, 2009

BAUMAN, Zygmunt. Vidas desperdiçadas. Rio de Janeiro: Jorge Zahar Editor, 2005

BERNADET, Jean-Claude. Brasil em tempo de cinema. Rio de Janeiro: Civilização Brasileira, 1966

O Bandido da Luz Vermelha. São Paulo: Fundação para o Desenvolvimento da Educação, 1990

O vôo dos anjos: Bressane, Sganzerla. São Paulo: Editora Brasiliense, 1990

CALASSO, Julio. Entrevista concedida à Paula de Maio Iglecio Cozzolino. São Paulo, 17/11/2015

CANDIDO, Antonio... [et al.]. A Personagem de ficção. São Paulo: Perspectiva, 2009

CANUTO, Roberta. O Bandido da Luz Vermelha [manuscrito]: por um cinema sem limite. Belo Horizonte: Universidade Federal de Minas Gerais, Faculdade de Letras, 2006

CINTRÃO, Rejane; SANT'ANNA, Margarida. 1963 Aproximações do espírito Pop 1968. São Paulo: Museu de Arte Moderna de São Paulo, 2003

COSTA, Luiz Cláudio da. Cinema Brasileiro (anos 60-70) - Dissimetria, Oscilação e Simulacro. Rio de Janeiro: 7 Letras, 2000

DAVID, Ana; SIMÕES, Daniele; BORBA, Morena. São Paulo: Estética Marginal volume\#2. Zupi Editora, 2012

EBERT, Carlos. Entrevista concedida à Paula de Maio Iglecio Cozzolino. São Paulo, $24 / 04 / 2013$

FALCÃO, Sarah. O cinema e a moda. João Pessoa: 2006. Disponível em: http://www.overmundo.com.br/overblog/o-cinema-e-a-moda Acesso em 14/06/2012 FERREIRA, Luiz Carlos. O temido Bandido da Luz Vermelha. São Paulo: 2013. Disponível em: http://f5.folha.uol.com.br/saiunonp/2013/10/1349858-o-temidobandido-da-luz-vermelha.shtml Acesso em 26/03/2016 
GARDNIER, Ruy. As mil máscaras de Dr. Rogério, cineasta. Contracampo: Revista de Cinema, número 58, sd. Disponível em http://www.contracampo.com.br/58/milmascaras.htm Acesso em 12/12/2012 GERBASE, Carlos. Direção de atores: como dirigir atores no cinema e TV. Porto Alegre: Artes e Ofícios, 2003

HAMBURGUER, Vera. Arte em cena: a direção de arte no cinema brasileiro. São Paulo: Editora Senac, 2014

IGNEZ, Helena. Entrevista concedida à Paula de Maio Iglecio Cozzolino. São Paulo, $22 / 07 / 2015$

JOSÉ, Ângela. Cinema marginal, a estética do grotesco e a globalização da miséria. Rio de Janeiro: publique.rdc.puc-rio.br, 2007

LA MOTTE, Richard. Costume design: the business and art of creating costumes for film and television. Michigan: McNughton \& Gunn, Estados Unidos, 2. Ed., 2010

LEITE, Adriana; GUERRA, Lisette. Figurino, uma experiência na televisão. São Paulo: Paz e Terra, 2002

LURIE, Alison. A linguagem das roupas. Rio de Janeiro: Rocco, 1997

MORAES, Ninho. Radiografia de um filme: São Paulo Sociedade Anônima. São Paulo: Imprensa Oficial, 2010

MORAES, Ricardo Leite de. A metáfora no Cinema Marginal: Análise sobre os motivos que levaram os autores marginais a utilizarem tal figura de linguagem em suas obras. Disponível em: http://www.uel.br/eventos/sepech/sumarios/temas/a metafora no cinema marginal analise sobre os motivos que levaram os autores marginais a utilizarem tal fi gura de linguagem em suas obras.pdf Acesso em 26/03/2016

NOGUEIRA, Ana Beatriz; PICCHETTI, Vanessa Catharino (org). Textos do Brasil: Moda 18. Brasília: Departamento Cultural do Ministério das Relações Exteriores, 2011

OLIVEIRA, Ana de. Tropicália. 2000. Disponível em: http://tropicalia.com.br/identifisignificados/movimento Acesso em 01/01/2013 PEREIRA, Dalmir Rogério. Alinhaves entre traje de cena e moda: Estudos a partir de Gabriel Villela e Ronaldo Fraga. São Paulo: Dissertação (Mestrado em Artes) - Escola de Comunicação e Artes da Universidade de São Paulo, 157 f., 2012 
PIZZINI, Joel. Documentário Rogério Sganzerla: Elogio da Luz. Rio de Janeiro: 2004. Disponível no site: https://www.youtube.com/watch?v=d8xRiHbPXoc . Acesso em 03/11/2015

PUPPO, Eugênio (org). Cinema Marginal brasileiro e suas fronteiras: filmes produzidos nos anos 60 e 70. São Paulo: CCBB, 2001

RAMOS, Fernão. Cinema Marginal (1968/1973): a representação em seu limite. São Paulo: Editora Brasiliense, 1987

RAMOS, José Mario Ortiz. Cinema, estado e lutas culturais: anos 50, 60, 70. Rio de Janeiro: Paz e Terra, 1983

REIS, Flávio. Cenas marginais: fragmentos de Glauber, Sganzerla e Bressane. São Luís: Lithograf (edição do autor), 2005

SGANZERLA, Rogério. Por um cinema sem limite. Rio de Janeiro: Azougue Editorial, 2001

SIMONARD, Pedro. Origens do cinema novo: cultura política dos anos 50 até 1964. Rio de Janeiro: Revista de Ciência Política, número nove, 2003. Disponível em: http://www.achegas.net/numero/nove/pedro simonard 09.htm Acesso em 20/12/2012

SOUZA, Julierme Sebastião Morais. Historiografia do cinema brasileiro e o crítico Paulo Emílio Salles Gomes: qual será o valor estético das chanchadas da Atlântida Cinematográfica? 2009. Disponível em: http://www.historiaehistoria.com.br/materia.cfm?tb=alunos\&id=249\# edn1 Acesso em 16/12/2012

SOUZA, Cyntia Santos Malaguti de; BASTOS, Helena Rugai. Materiais, técnicas e processos de design: diretrizes para a implementação de observatório de mudanças. Gramado: Blucher Design Proceedings, $11^{\circ}$ P\&D Design, Volume 1, Número 4, Novembro 2014.2 Disponível em: http://pdf.blucher.com.br/designproceedings/11ped/01405.pdf Acesso em 02/11/2015 TOLEDO, Marina Sartori de. A teatralização da moda brasileira: os desfiles da Rodhia nos anos 60. São Paulo: Universidade de São Paulo, 2004 TURIGLIATTO, Roberto. Entrevista concedida para a exposição "Ocupação Rogério Sganzerla" realizada no Itaú Cultural. São Paulo, junho/julho 2010. Disponível no site: $\quad$ http://sites.itaucultural.org.br/ocupacao/\#!/pt/artistas/106/rogeriosganzerla/358/radiografia/7644/roberto-turigliatto . Acesso em 13/11/2015 
VIANA, Fausto. O figurino teatral e as renovações do século $X X$. São Paulo: Estação das Letras e Cores, 2010

VIANA, Fausto, PEREIRA, Dalmir Rogério. Figurino e cenografia para iniciantes. São Paulo: Estação das Letras e Cores, 2015

VISCONTI, Elyseu. Entrevista concedida para a exposição "Ocupação Rogério Sganzerla" realizada no Itaú Cultural. São Paulo, junho/julho 2010. Disponível no site: $\quad$ http://sites.itaucultural.org.br/ocupacao/\#!/pt/artistas/106/rogeriosganzerla/358/radiografia/7640/elyseu-visconti . Acesso em 03/11/2015

XAVIER, Ismail. Alegorias do subdesenvolvimento: Cinema Novo, Tropicália e Cinema Marginal. São Paulo: Brasiliense, 1993

\section{Filme}

BANDIDO da Luz Vermelha. Direção de Rogério Sganzerla. São Paulo: Versátil Home Vídeo, 2007. 1 DVD (92 min): NTSC, son., p\&b. Idioma original port. 